\title{
Building Armies,
} Building Nations

Toward a New Approach to Security Force Assistance

Michael Shurkin, John Gordon IV, Bryan Frederick,

Christopher G. Pernin 
For more information on this publication, visit www.rand.org/t/RR1832

Library of Congress Cataloging-in-Publication Data is available for this publication.

ISBN: 978-0-8330-9741-5

Published by the RAND Corporation, Santa Monica, Calif.

(C) Copyright 2017 RAND Corporation

RAND $^{\circ}$ is a registered trademark.

\section{Limited Print and Electronic Distribution Rights}

This document and trademark(s) contained herein are protected by law. This representation of RAND intellectual property is provided for noncommercial use only. Unauthorized posting of this publication online is prohibited. Permission is given to duplicate this document for personal use only, as long as it is unaltered and complete. Permission is required from RAND to reproduce, or reuse in another form, any of its research documents for commercial use. For information on reprint and linking permissions, please visit www.rand.org/pubs/permissions.

The RAND Corporation is a research organization that develops solutions to public policy challenges to help make communities throughout the world safer and more secure, healthier and more prosperous. RAND is nonprofit, nonpartisan, and committed to the public interest.

RAND's publications do not necessarily reflect the opinions of its research clients and sponsors.

\section{Support RAND}

Make a tax-deductible charitable contribution at www.rand.org/giving/contribute 


\section{Preface}

This report explores the relationship between armies and nation-building and argues that U.S.-sponsored Security Force Assistance (SFA) might be improved were there less focus on force structure, military capabilities, and readiness, and more on ideology and the extent to which an army complements a host nation's larger nation-building project. While SFA doctrine and comparable guidelines call for working toward enhancing government legitimacy, this report argues that legitimacy is often a function of ideas, identities, and ideologies. Armies historically have played an important role by embodying and promoting specific ideas, identities, and ideologies, and otherwise by bridging the people with the nation. This report uses six case studies-three historic cases of large-scale U.S. SFA programs (South Korea, Vietnam, and Iraq) and three cases of attempts by postcolonial states (Ghana, Mali, and Nigeria) to invent themselves, with the military sometimes playing an important role-for the purpose of examining relationships between armies and nation-building and the potential role of SFA.

The purpose of this report is to identify ways to improve SFA provision. Recent events in Iraq as well as Mali have raised questions about the value of SFA and U.S. capacity to strengthen client states' militaries in the face of insurgencies or other significant threats. While stopping short of policy prescription, this report is intended to suggest possible improvements to SFA by arguing for a different approach as well as to stimulate further debate and research.

This research was sponsored by the Deputy Chief of Staff G-8, Army Quadrennial Defense Review Office, and conducted within the 
RAND Arroyo Center's Strategy, Doctrine, and Resources Program. RAND Arroyo Center, part of the RAND Corporation, is a federally funded research and development center sponsored by the United States Army.

The Project Unique Identification Code (PUIC) for the project that produced this document is HQD146835. 


\section{Contents}

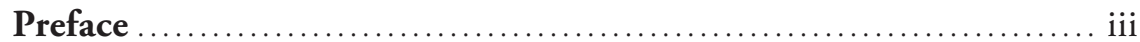

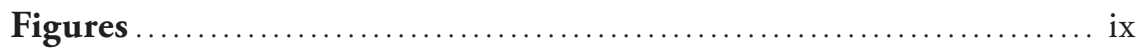

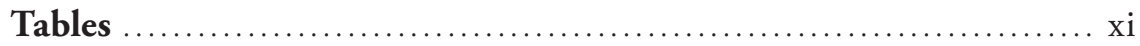

Summary ................................................... xii

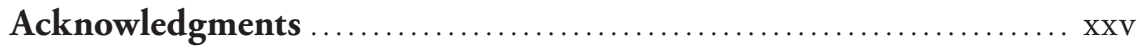

Abbreviations ................................................ xxvii

CHAPTER ONE

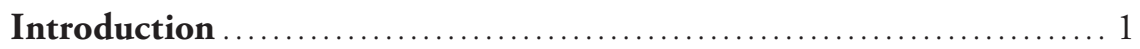

Definitions ................................................... 4

Current Theory and Doctrine ..................................... 5

Nation-Building and Revolutions ............................... 12

Revolutionaries and Counter-Revolutionaries .........................29

Ideology and Cohesion ......................................... 32

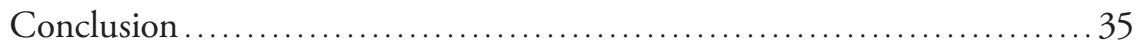

\section{CHAPTER TWO}

The Army of the Republic of Korea and the

U.S. Advisory Mission .................................... 37

A Nation Contested, 1945-1950 ................................ 38

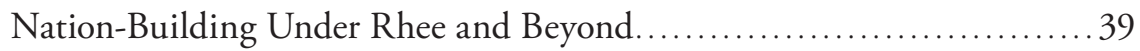

The Republic of Korea Army ...................................... 45

Korea's Mixed Record ............................................. 54 
CHAPTER THREE

The Army of the Republic of Vietnam .......................... 57

The Birth of South Vietnam ........................................... 61

Making the ARVN in the American Image .......................... 66

From Vietnamization to Collapse ................................... 72

Why the ARVN Was Not the Nation-Building Force It

Could Have Been ............................................... 73

What MACV Got Wrong ..................................... 90

Conclusion ................................................... 94

\section{CHAPTER FOUR}

The Iraqi Army .............................................. 97

1920-2003: Building the Nation, Contesting the State................ 97

2003-2014: Rebuilding the State, Dividing the Nation ............... 105

Conclusion .................................................. 124

CHAPTER FIVE

The Ghanaian Army ........................................ 129

Introduction ................................................. 129

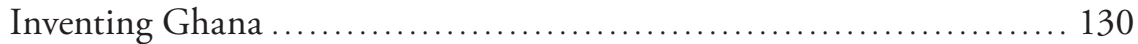

Falling Back to Earth ............................................ 134

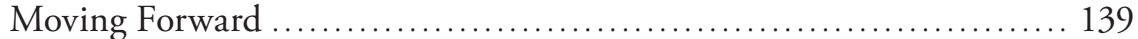

Shapers of Normative Values ..................................... 141

A U.S. Role? ................................................. 150

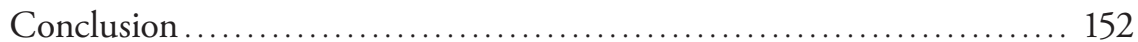

\section{CHAPTER SIX}

The Malian Army ............................................. 153

Background to Mali's Conflicts: Diversity and National Identity ....... 155

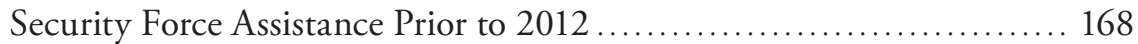

Roots of Failure ........................................... 172

Civic Education and Identity Formation.......................... 174

Conclusion ................................................... 176 
CHAPTER SEVEN

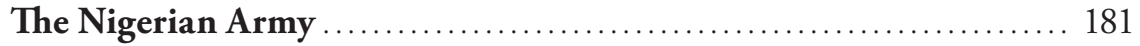

A History of Division .............................................. 183

The Military and Nation-Building ............................. 186

Conclusion ................................................... 199

CHAPTER EIGHT

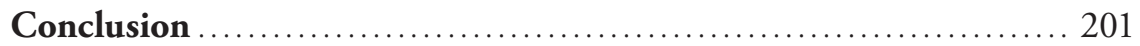

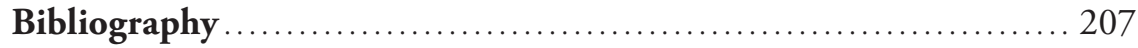





\section{Figures}

1.1. The Ritual Planting of a Liberty Tree by French Revolutionaries with Blue, White, and Red Sashes and Cockades and Phrygian Caps....

1.2. The Federation Festival Commemorating the Anniversary of the Fall of the Bastille and the Unity of the French People, Held at Paris, July 14, 1790

1.3. The Oath of La Fayette (Wearing the Blue, White, and Red Uniform of the National Guard, Which Became the Colors of the Revolution) at the Federation Festival, July 14, 1790

1.4. The IDF's Givati Brigade Participating in Evening Prayers at the Western Wall, the Symbolic Focal Point of the Jewish People ....

1.5. A French Catholic Counter-Revolutionary with White Cockade (the Color of the Monarchy) and Sacred Heart Badge, Symbol of Piety ...................... 30

4.1. Transition Readiness Report Form for the Iraqi Army....... 114

4.2. Image from The Hawk, Iraq Justice and Peace Comic Book.

5.1. Billboard at Entrance to Burma Camp ................... 147

6.1. The Gateway to the Army Base in Gao Named After the Tuareg Leader Firhoun ag Alincar ............... 161

7.1. Nigerian Linguistic Groups 



\section{Tables}

5.1. Regime Change in Ghana, 1957-Present................. 137

5.2. Selected UN Missions and the Role of the Ghanaian Armed Forces (2015) ....................... 148

7.1. Nigeria’s Military Rulers ............................. 182 



\section{Summary}

Security Force Assistance (SFA) and other forms of security cooperation (SC) intended to strengthen the security forces of partner nations that are struggling to address domestic and transnational threats are becoming an increasingly central part of U.S. national security policy. However, the travails of Afghan, Iraqi, and other nations' security forces trained and equipped at great expense by the United States raise questions, including whether the United States sees acceptable results from these investments. The implied negative judgment is, in many ways, unfair, given the variety of SFA-related programs and their objectives; yet, it points to the reality that current doctrine can be improved.

This report aims to explore the hypothesis that there might be a better way to conduct SFA, one informed by an understanding of the role that armies often have played in successful instances of nationbuilding. We argue for the critical importance of national identity and ideology for nation-building and legitimacy formation, the role militaries can play by embodying and promoting a national idea, and the importance of ideology for military cohesion and, ultimately, its effectiveness. Militaries, moreover, can form a bridge between state and nation (the people), not just by interacting with civilians and not abusing them but also through gestures and rituals that symbolically promote a particular definition of the national community and draw civilians within it.

In contrast, current doctrine posits the importance of fostering legitimacy but ultimately identifies the tasks of SFA in terms of a focus on force structure, operational effectiveness, and readiness as conven- 
tionally measured. Legitimacy is presumed to flow from having an effective force that also obeys the law (i.e., does not abuse civilians) and helps the state provide "governance." SFA doctrine regards the work of building a military as fundamentally apolitical, perhaps in reflection of the consensus that militaries ideally should be apolitical, even though such a view is fundamentally false. ${ }^{1}$

Successful SFA therefore presupposes the existence of a national identity and ideology or, at the very least, the will on the part of the national leadership to elaborate a compelling narrative of the nation and promote it among the population through a variety of means, including the military. The implication is that the less national leaders are attentive to the ideological aspects of nation-building, the less effective they are in implementing nation-building schemes, and the less SFA can be expected to accomplish. SFA might still be valuable, but implementers would have to adjust their ambitions accordingly. What remains to be determined is how much the United States, as an outsider, hopes to achieve. This report argues for the possibility of making constructive contributions by seeking opportunities to reinforce or guide host-nation efforts.

We explore the subject through two sets of case studies. The first set of cases was selected to illuminate the role, or lack thereof, of the promotion of a coherent national identity in past instances of largescale U.S. SFA and includes studies of Korea, Vietnam, and Iraq. These cases are intended to highlight the extent to which host-nation leaders and their U.S. advisors concerned themselves with the army's development in the context of a larger nation-building program. The second set of cases was selected to explore how fragile or weak states have attempted to use their armies in their attempts at nation-building, with sometimes mixed results. These cases include studies of Ghana, Mali, and Nigeria. We selected these specific cases because each country faced challenges that are common to fragile states-namely weak state institutions, poor governance, and diverse populations-and because

1 Having an army is intrinsically political, and armies tend to-since the French Revolution, at least on some level-represent the state, promote legitimating narratives about the state, and connect the state with the nation. 
we had access to sufficient information about the efforts of these states to use their militaries in this manner.

\section{The Army of the Republic of Korea}

South Korea offers our first historical example of a nation that benefited from a massive U.S. SFA program. Korea represents a success story that contrasts sharply with Vietnam: The South Koreans, with help from the United States and the United Nations, prevailed in war, and the Army of the Republic of Korea (ROKA) rapidly evolved from a light internal security force into a highly capable conventional military. The myriad differences between the South Korea and Vietnam cases make it difficult to attribute the Koreans' relative success to any particular factor, although a few salient points do emerge. One is the conscious and effective effort on the part of the Republic of Korea (ROK) civilian and military leadership to elaborate and promote a specific national identity and ideology that reinforced state legitimacy and helped the young republic overcome significant challenges. The Korean government executed this effort in the context of a robust and comprehensive nation-building effort. It emphasized economic development, but it also was attentive to education and other sectors that, among other things, have contributed not just to the ROK's current prosperity but arguably also its strong sense of identity. Another salient point is the Korean military's U.S. advisors' attention to identity and ideology as part of that broader nation-building strategy. Koreans already were cultivating this aspect, but the United States encouraged the ROK by trying to direct their efforts and helping them build associated content into soldiers' education and professional training.

One forgotten aspect of Korean history that merits emphasis is the ROK's lack of inherent legitimacy: The United States created the ROK by handing what was essentially the colonial state and police that had been created by the hated Japanese to a cadre of right-wing nationalists, thereby frustrating Koreans' aspirations for independence, their desire to purge the nation of Japanese collaborators, and their hopes for enacting badly needed economic reforms. It did not help that, when 
the United States stood up first a Constabulary force and then transformed it into the ROKA, it relied on veterans of either the Japanese army or the army of Japan's puppet state in Manchuria, Manchukuo. Unsurprisingly, political opposition within the ROK quickly devolved into an insurgency and mutiny, much of it leftist in orientation, which flowered from 1946 to 1950 . Meanwhile, the communists who controlled the northern half of the peninsula enjoyed stronger nationalist credentials because of their resistance to the Japanese and their offer to end rather than reinforce sharp socioeconomic imbalances. The communists had a compelling narrative of the nation and a legitimating ideology; the U.S.-backed anticommunists in the south did not and instead had to create one.

Remarkably, Korea's leaders organized a comprehensive nationbuilding project that included elaborating and promoting identities and ideologies supportive of the ROK in its conflict with communism while also, beginning in 1950, standing up a large conventional army that, by 1953, had become a highly capable force. Critically, for the ROK's leaders, the ROKA was always more than just a tool for providing security and countering internal and external threats; it was a nation-building arm that complemented other efforts by such entities as the school system and youth movements. U.S. advisors assisted where they could. Most notably, they were attentive to the ROK leaders' efforts to shape the country's political culture and concerned themselves with influencing ROK policies to strengthen liberal values wherever they could. With respect to the ROKA, the United States resisted the temptation to grow the Korean force as quickly as possible and preferred to prioritize quality over quantity, which meant concentrating on education, training, and attending to Korean officers' esprit de corps, morale, and patriotism. In other words, U.S. FSA complemented South Korea's nation-building efforts rather than simply focus on force structure, capabilities, and readiness.

The ROKA's record of politicization and outright coups suggests the hazards associated with having a military with an explicitly political vocation. Nonetheless, the net results of Korean efforts to build the nation and establish the republic's legitimacy are clear. We also find an example of the United States using SFA to guide Korean efforts to 
foster-within the force and within the Korean state and society in general-particular ideas relating to national identity and patriotism.

\section{The Army of the Republic of Vietnam}

South Vietnam, like South Korea, began life with little, if any, inherent legitimacy. The fledgling republic-largely a creature of the outgoing French colonial government-had to build an army while forging a nation in the face of stronger rival claims to power. Vietnam's first leader, Ngo Dinh Diem (president of the Republic of Vietnam, 19551963), had clear ideas for how to build and modernize the country, although his plans arguably were flawed and his execution inconsistent and not always effective. Among other things, he reportedly was reluctant to cultivate Vietnamese nationalism or mobilize popular support. After Diem was ousted in a U.S.-backed coup, his successors were significantly less concerned with nation-building than Diem.

With the U.S. advisory mission, Diem built the Army of the Republic of Vietnam (ARVN) into a large conventional army designed primarily to counter the threats posed by communist "main force" units (i.e., large and fairly conventional Vietcong and North Vietnamese regular army units). In contrast to the Korean case, Vietnamese leaders appeared to pay little attention to the cohesion and ideological orientation of the force. Their U.S. advisors were not unaware of problems, yet tended, for a number of reasons, to focus on more conventional matters related to force structure, readiness, and administrative matters associated with morale, such as housing and pay. Similarly, rather than build the ARVN into something that might bridge Vietnamese society with the state and foster legitimacy, the ARVN appeared to have the opposite effect. One reason is mass conscription, which stressed rural Vietnamese society. Saigon did not effectively mitigate the harm done by finding ways to soften the blow of conscription and to sell it and the populace in terms of Vietnamese culture or history. North Vietnam, in contrast, did a more successful job of managing the strain of conscription and framing it in appropriate cultural terms. Moreover, the ARVN's conventional approach to war fighting also exacted a toll 
because of the heavy use of firepower, which caused deaths and property damage among the civilian population and exacerbated the state's legitimacy deficit.

Although many factors contributed to the north's ultimate victory in 1975, it appears that the ARVN struggled to be as effective as its size would suggest in part because of a lack of cohesion associated with the absence of a clear political cause and the lack of any real loyalty to Saigon. This, in turn, reflects a larger problem: South Vietnam's failure effectively to implement a nation-building plan, one that might have featured developing the ARVN to complement the larger nationbuilding effort and enhance state legitimacy in the face of competition from Vietnamese communists.

\section{The Iraqi Army}

Iraq's army has played an important, albeit inconsistent role, with respect to nation-building. Generally, it has helped foster national identity, particularly as the country emerged from British control. However, the extent to which the Iraq army might have played a positive role as a vehicle for a unifying ideology and a bridge between state and nation has often been limited by the tendency for one or several subsets of Iraqi society - often certain tribes - to dominate the force. Saddam Hussein used the army as a key pillar of the Ba'athist state, although concern for coup-proofing the force and keeping it from developing its own corporate identity encouraged Saddam to balance the army with the Republican Guard. Promotions, moreover, often depended on personal or tribal loyalties, which similarly hindered the development of the army as an entity that could unify Iraqis and bridge the state with the nation.

The experience of the Iran-Iraq War brought together Iraq's diverse population and fostered a unifying Iraqi national identity. The army, in this context, emerged as an important symbol that promoted national unity and pride. That unity, it should be stressed, crossed ethnic and sectarian lines, as Iraqi Shia served in great numbers and remained loyal to the Iraqi state throughout the bloody conflict. At the 
same time, as people came to identify with the Iraqi army, poor leadership of the army and misuse of the force had the effect of undermining support for the regime itself. Iraqis might have been more patriotic, but not necessarily more loyal to, Saddam.

The 2003 U.S. invasion and the U.S. government's decision to disband the Iraqi army - a decision informed in part by the mistaken belief that Iraqis associated the Iraqi army with Saddam's regimecreated a situation in which the United States had to work with some chosen elements to rebuild the Iraqi state and army from scratch without benefiting from any of the legitimacy the state and army may have enjoyed previously. As we have seen before, the task may have been possible with strong leadership, a strong vision of what modern Iraq should be, an ideology that was inclusive of Iraq's diverse communities, and attention paid to developing the army in such a way that it might complement the larger nation-building project. In the face of the growing insurgency, however, Iraqi leadership appeared inattentive to the ideological aspects of nation-building, while U.S. advisors, arguably repeating the Vietnam-era advisory mission, elected to focus on building the Iraqi army as quickly as possible in the hope that the United States might be able to withdraw quickly. The situation worsened under Prime Minister Nouri al-Maliki, who acted to coup-proof the military while progressively placing it — and the state-at the service of sectarian Shia interests. The available evidence strongly suggests that the United States, although aware of the sectarian issues and trends exhibited by Iraq's leadership, concerned themselves with force structure, capabilities, and readiness, leaving "politics" to others.

It appears, however, that al-Maliki's actions were contrary to the idea of creating a force to bridge the state and nation. This had consequences for the military's effectiveness on the battlefield and provided a clear example of how the metrics of readiness can be a poor barometer of whether or not a force can foster legitimacy and stand and fight while under duress. Among other things, the collapse of the Iraqi army, when attacked by the Islamic State in 2014, can be attributed to a total breakdown in trust between the local Sunni population and the Iraqi state. The local Sunni population had become alienated from the army and, as the Islamic State advanced, few believed that Iraqi forces 
would protect the local population. As a result, Sunni soldiers were often among the first to desert their posts in Mosul, fearful that the Islamic State would retaliate against their families if they fought and doubtful that Iraqi forces would do anything to prevent it. Al-Maliki's use of the security forces as a tool to ensure his own hold on power hollowed out the force of much of its effective leadership and divorced it from the population it was originally meant to protect, particularly in Sunni areas.

\section{The Ghanaian Army}

Ghana shares with the previous cases a colonial past and a leadership that possessed and articulated an inclusive and united vision for the nation's future. It also understood the potential for the army-one that embodied the new vision - to promote it and bridge the nation with the state. Ghana's leaders, especially the nation's founding father, Kwame Nkrumah (prime minister, 1951-1966), aspired to create a detribalized state and army that transcended ethnic cleavages and had a singular Ghanaian identity. Ghana, by and large, has been successful, with the government and its army often held up as exemplary, notwithstanding a history of political instability, military coups, and a record of the army interpreting its role as champion of the nation as license to overthrow elected governments.

Many factors have contributed to Ghana's relative success. Among them is the legacy of Nkrumah, who, although not the most effective nation-builder, was instrumental in creating a modern Ghanaian identity that has helped unify the country's diverse population. Another, of course, is the lack of an external threat, meaning that Ghana's military has never really been tested on the battlefield or even felt the pressure to focus on force structure or capabilities. In recent decades, Ghana has focused instead on conducting international peacekeeping operations (PKOs). Its involvement in $\mathrm{PKOs}$ has been beneficial in a number of ways. Among them is that experience working in war-torn countries reportedly encourages Ghanaian troops to have a greater appreciation for their own country and a desire to protect its political stabil- 
ity. Another is the influence of the army's focus on such PKO-related operations as civil-military operations and civil-military cooperation on its approach to relations with Ghana's own civilian population. The Ghanaian military is mindful of the need to cultivate positive relations with civilians and acts accordingly.

Ghana has long been the recipient of U.S.-provided security assistance and SFA. The effect of such assistance is hard to gauge. One point that can be made is that, by and large, U.S. aid has corresponded well with the country's requirements. Ghana needs a disciplined professional force more than it needs a militarily capable one; it also needs help with PKOs. U.S. assistance has focused on those specific requirements. It is possible that, had the United States drafted Ghana into military campaigns or even the Global War on Terror, U.S. assistance might have focused on matters other than the country's basic requirements. Meaning, rather than focus on professionalization, the United States might have focused on force structure or military capabilities. Thus, although it is hard to determine if U.S. assistance helped Ghana (i.e., if Ghanaian officers today are more professional because of U.S. programs than they would otherwise be), at least U.S. help was not of the nature to harm Ghana or detract Ghana's leadership from nationbuilding and building on the country's progress so far.

\section{The Malian Army}

The Malian army is a counterexample to the Ghanaian experience. While Mali, like Ghana, emerged from colonial custody with an already-present national identity and a leadership keen on promoting it, Malian identity tended to exclude certain key minority groups, most importantly Arab and Tuareg inhabitants of the country's north. Additionally, its leaders, rather than work to foster a unifying identity, exacerbated divisions. The Malian army, which might have contributed to promoting ideology among southern Malians, acted toward the northern populations in ways that polarized relations and emphasized both sides' view that the other was foreign. The country's response to successive insurgencies in the north further exacerbated matters. Today, 
Mali's military leaders still neglect the force's potential contribution to nation-building. The available evidence suggests a lack of commitment to the idea of trying to create a unifying force as well as the belief that its present approach to ethnic diversity is an appropriate remedy when, in fact, it has the opposite effect.

Beginning in 2001, the United States drafted Mali into its global antiterrorism campaign and began providing the country assistance intended to enhance the Malian army's counterterrorism capabilities. U.S. assistance focused on tactical capabilities, with little attention paid to the integrity of the entire force, its cohesiveness, its ideology, and the extent to which the force bridged the state with the nation or acted to divide them, especially in the north. Although the U.S. mission appears to have insisted on diversity within the Malian units that received training and equipment, it largely left the task of selecting and vetting participants to the Malians and asked few if any questions regarding their backgrounds. The United States also did not attend to questions of ideology or indoctrination in general, something the Malians also neglected. These missteps may have contributed to the poor performance of U.S.-trained units in 2012, when many dissolved in the face of rebel attacks.

\section{The Nigerian Army}

Nigeria, in contrast to the other cases discussed here, is a pure invention. It also is a much larger country with an even greater diversity, making the basic task of nation-building and unifying its diverse peoples particularly challenging. Nigeria's earliest leaders appear to have understood the nature of the task before them and also identified the army as an essential component of the larger nation-building project. Indeed, the Nigerian military is a pillar of the national state and a champion of national Nigerian identity.

That said, the challenge of establishing a national government and national institutions (including the military), while also arbitrating disputes among the country's different regions and ethnic groups, often has had the better of the country's leaders; its military, imbued 
with the idea that it exists in part to champion national identity and the national government, often has succumbed to the temptation of interfering in politics and displacing elected governments. Perhaps more problematic is the country's resource curse: Oil revenue began to flow in large quantities just after a pivotal moment in the nation's history, when the country's leadership defeated a rebellion and then acted in exemplary ways to reintegrate rebel populations and members of the rebel military; it appears that capturing and diverting wealth quickly became a priority for the nation's leadership class. As the country has struggled to right itself, the military has continued to play an important role promoting unity.

\section{Conclusion}

The cases in this summary demonstrate various paths that different fragile states have taken to construct themselves as fully fledged cohesive nations and the ways they approached building their militaries in the context of a larger nation-building project. The sheer number of factors involved in the successes and failures of different countries are enough to discourage reductionism; however, it is our contention that ideas and ideology are critical to nation-building as well as combat effectiveness. To the extent that U.S. SFA programs tend to neglect such matters while focusing on more concrete and countable elements such as force structure, capabilities, and readiness, they are at risk of missing the point with respect to what it takes for a state to defeat threats to its legitimacy represented by armed opposition. Ideology matters for more than just insurgents; counterinsurgents-such as counter-revolutionaries-are engaged in an ideological struggle and, at the least, are almost certain to benefit from having a cause worth fighting for, especially one that also serves to legitimize the force and the state.

The success of SFA and the opportunities for constructive interventions depends on the host nation itself, and the United States would do well to calibrate its ambitions in accordance with the extent to which the host nation takes seriously the idea of building a force that complements its larger nation-building effort (or even if it has one). The 
xxiv Building Armies, Building Nations

Korean case suggests the possibility of finding opportunities to guide host-nation activities. Less clear is whether or not the United States can convince the host nations' leadership who are uninterested in promoting a national ideology and using the force to promote it to change their priorities. 


\section{Acknowledgments}

We would like to thank the RAND Arroyo Center and Terry Kelly, Wade Markel, Mike Mazarr, and Sally Sleeper for their patience and support. Matthew Carrol, Raphael Cohen, and Stephanie Pezard all made significant contributions to this effort. Our readers, Gian Gentile, Adam Grissom, and Derek Reveron, provided invaluable constructive criticism. We also wish to aknowledge the invaluable editorial and administrative support provided by Linda Theung, Gina Frost, Betsy Kammer, and Rhonda Normandin. 



\section{Abbreviations}

ARVN Army of the Republic of South Vietnam

AU African Union

CFS Compagnie Forces Speciales

CIA Central Intelligence Agency

CIMIC Civil-Military Cooperation

COIN counterinsurgency

CPP Convention People's Party

DoD U.S. Department of Defense

ECOWAS Economic Community of West African States

ETIA Echelon Tactique Interarmes

EUTM European Union Training Mission

FAMa Forces Armées Maliennes

FSF foreign security forces

GAO U.S. Government Accountability Office

GATIA Groupe Autodéfense Touareg Imghad et Alliés

GN Gendarmerie Nationale

IDF Israeli Defense Force

IMET International Military Education and Training

JCET Joint Combined Exchange and Training

JPAT Joint Planning and Assistance Team

JSOTF-TS Joint Special Operations Task Force-Trans Sahara 


$\begin{array}{ll}\text { KMA } & \text { Korean Military Academy } \\ \text { KMAG } & \text { U.S. Military Advisory Group to the Republic of } \\ \text { MAAG } & \text { Morea } \\ \text { MACV } & \text { Military Assistance Advisory Group } \\ \text { MAMSER } & \text { Mass Mobilization for Self Reliance, Social } \\ & \text { Justice, and Economic Recovery } \\ \text { MNSTC-I } & \text { Multinational Security Transition Command-Iraq } \\ \text { MOD } & \text { Ministry of Defense } \\ \text { NCCE } & \text { National Commission for Civic Education } \\ \text { NCO } & \text { noncommissioned officer } \\ \text { NLC } & \text { National Liberation Council } \\ \text { NRC } & \text { National Redemption Council } \\ \text { NVA } & \text { North Vietnamese Army } \\ \text { OCINC } & \text { Office of the Commander in Chief } \\ \text { PKMAG } & \text { Provisional Korean Military Assistance Group } \\ \text { PKO } & \text { peacekeeping operations } \\ \text { PME } & \text { Professional Military Education } \\ \text { PSI } & \text { Pan-Sahel Initiative } \\ \text { RCP } & \text { Regiment de Commandos Parachutistes } \\ \text { ROK } & \text { Republic of Korea } \\ \text { ROKA } & \text { Republic of South Korea Army } \\ \text { ROK-MAG-V } & \text { Republic of Korea Military Assistance } \\ \text { SA } & \text { Group-Vietnam } \\ \text { SC } & \text { security assistance } \\ \text { SFA } & \text { security cooperation } \\ \text { SOF } & \text { security force assistance } \\ \text { SSA } & \text { special operations forces } \\ \text { SSR } & \text { Security Sector Assistance } \\ \text { SOrity sector reform }\end{array}$


TSCTP Trans-Saharan Counterterrorism Partnership

UN United Nations

USAFRICOM U.S. Africa Command

USEUCOM U.S. European Command

VNA Vietnamese National Army 



\section{Introduction}

The theory and doctrine of U.S. security force assistance (SFA) have come a long way since Vietnam, yet the travails of Afghan and Iraqi security forces trained at great expense by the United States suggest that there is room for improvement. Indeed, many have questioned the ability of the United States to strengthen client states' militaries, notwithstanding the fact that doing so is increasingly central to U.S. security strategy. Numerous articles, studies, and even congressional hearings - such as one convened by the House Armed Services Committee in October 2015-question the poor "return on the investment" of U.S. security cooperation efforts. ${ }^{1}$

To be fair, we must be careful to acknowledge that, as Derek Reveron argues, limited SFA, security assistance (SA), and security cooperation (SC) programs of the United States are successful, particularly in achieving their broader strategic objectives, which may differ from their stated purpose. ${ }^{2}$ For example, some programs exist primar-

1 Dafna Rand and Stephen Tankel, Security Cooperation and Assistance: Rethinking the Return on Investment, Washington, D.C.: Center for a New American Security, August 5, 2015, p. 3; U.S. House of Representatives, "Statement of Dr. Derek S. Reveron Professor, National Security Affairs, U.S. Naval War College Newport, R.I., Before the House Armed Services Committee on Security Cooperation," Washington, D.C.: U.S. Government Printing Office, October 21, 2015; Andrew J. Shapiro, "A New Era for U.S. Security Assistance," Washington Quarterly, Vol. 35, No. 4, Fall 2012.

2 Derek S. Reveron, "Weak States and Security Assistance," Prism, Vol. 1, No. 3, 2010; U.S. House of Representatives, 2015; Derek S. Reveron and Oleg Svet, "Should the U.S. Increase Security Cooperation to Address Terrorism?” Security Assistance Monitor, December $16,2015$. 
ily to ensure U.S. access to bases, meaning that, even if a program (e.g., a training course) does not achieve its ostensible objective (e.g., training fails), the program nonetheless can be considered a success if base access continues. SC programs, after all, have a large number of policy and even economic objectives. They might, for example, exist to sell U.S.-made equipment, perhaps to protect jobs, keep production lines open, or promote interoperability. Yet, Reveron and others acknowledge that critical, large-scale SA and SFA efforts to improve the militaries of such fragile and weak states as Afghanistan and Iraq have gone poorly. As Reveron put the matter recently:

When it comes to industrial-scale security cooperation efforts in Afghanistan and Iraq, the results are dismal. Despite spending $\$ 25$ billion on training and equipping of the Iraqi Security Forces (ISF), Iraq was unable to meet basic security functions of a sovereign state as evidenced by the rise of ISIL. In Afghanistan, the United States spent $\$ 65$ billion on training and equipping the Afghan National Security Forces (ANSF) since 2002, yet the ANSF have been unable to secure much of the country. ${ }^{3}$

This report aims to explore the hypothesis that the manner and the circumstances in which large-scale U.S. SFA are currently applied are flawed. Further, we suggest that there might be a better way to implement U.S. SFA, one informed by an understanding of the role that armies have often played in successful instances of nation-building. This hypothesis argues that the relationship among armies, governments, and peoples in modern times, at least since the French Revolution, is vital for the success of both the armies and the governments. Further, the report argues that these crucial issues of national identity and the role of the military in promoting and serving it have been neglected to the detriment of U.S. ability to build effective forces as well as its ability to recognize circumstances where success in building such forces is unlikely.

We explore the subject through two sets of case studies. The first set of cases was selected to illuminate the role, or lack thereof, of the

3 Reveron and Svet, 2015. 
promotion of a coherent national identity in past instances of largescale U.S. SFA and includes studies of Korea, Vietnam, and Iraq. These cases are intended to highlight the extent to which host-nation leaders and their U.S. advisors concerned themselves with the army's development in the context of a larger nation-building program. The second set of cases was selected to explore how fragile or weak states-those states where large-scale U.S. SFA will be attempted in the future-have attempted to use their armies in their attempts at nation-building, with sometimes mixed results. These cases include studies of Ghana, Mali, and Nigeria. We selected these specific cases because each country faced challenges that are common to fragile states - namely weak state institutions, poor governance, and diverse populations-and because we had access to sufficient information about the efforts of these states to use their militaries in this manner.

With respect to lessons for the U.S. Army regarding how to do large-scale SFA, the implications of our report are potentially profound. It may be all but impossible for the United States to build effective security forces in certain circumstances, or the manner in which the United States approaches the task may need to be fundamentally redesigned. It might be the case that the most we can hope to achieve is a limited objective. While that might suit U.S. interests well, it is always beneficial to calibrate one's ambitions appropriately. However, our intention in this report is to further debate on these issues rather than prescribe specific courses of action. We believe there is value at this stage in closely examining what a number of experts consider to have been grave errors in U.S. approaches to SFA in the past, while acknowledging that one cannot prove that different approaches would have yielded success. Nonetheless, we believe that investigations of these cases, as well as instances where developing nations have tried to build their militaries largely on their own, can identify what may be better approaches, as well as what circumstances may be necessary for such efforts to be effective. 


\section{Definitions}

For the purposes of this report, we distinguish between SFA, SA, security sector assistance (SSA), and other related terms in keeping with the definitions provided by the Joint Doctrine Note 1-13, Security Force Assistance. ${ }^{4}$ The term security cooperation refers to the broad category of activities undertaken by the U.S. Department of Defense (DoD) "to encourage and enable international partners to work with the U.S., to achieve strategic objectives." 5 SC can include any and all interactions between U.S. defense officials or the U.S. military and foreign defense officials or foreign militaries. ${ }^{6}$

Security force assistance refers to DoD and U.S. Department of State activities that "support the development of capability and capacity of foreign security forces (FSF) and supporting institutions."” SFA activities are "primarily used to assist an HN [host nation] in defending against internal and transnational threats to stability (i.e., supporting foreign internal defense [FID], counterterrorism, counterinsurgency [COIN], or stability operations). ${ }^{8}$

In contrast, security assistance refers to a group of SC programs "authorized by the Foreign Assistance Act of 1961, as amended, the Arms Export Control Act of 1976, as amended, Title 22, United States Code, as amended, or other related statutes, by which the U.S. provides defense articles, military training, and other defense-related services to foreign nations by grant, loan, credit, or cash sales in furtherance of national policies and objectives." Not all SA programs can be considered SFA, although SFA generally requires SA programs. Examples of $S A$ programs include the foreign military sales program, the foreign

\footnotetext{
4 Joint Doctrine Note 1-13, Security Force Assistance, Washington, D.C.: U.S. Department of Defense, 2013.

5 Joint Doctrine Note 1-13, 2013.

6 Joint Doctrine Note 1-13, 2013, p. vii.

7 Joint Doctrine Note 1-13, 2013.

8 Joint Doctrine Note 1-13, 2013, p. vii.

9 Joint Doctrine Note 1-13, 2013, p. vii.
} 
military financing program, and the international military education and training (IMET) program. ${ }^{10}$

Security sector reform (SSR) and SSA reflect a new approach to SA and SFA that involve more holistic and often interagency interventions intended to go beyond addressing host-nation military capacity and capabilities and instead address government security-related institutions as a whole as well as such nonmilitary aspects of governance as justice. ${ }^{11}$

We believe that SFA is what most have in mind when they think about perceived failures in Afghanistan and Iraq or, before these cases, Vietnam, and thus prefer to focus on these in this report. We do so cognizant of the fact that SSR and SSA, to a large extent, define the latest thinking regarding how to do SFA, particularly in light of the 2013 publication of Presidential Policy Directive 23, Security Sector Assistance. ${ }^{12}$

\section{Current Theory and Doctrine}

Since the invasion of Iraq in 2003, the numerous doctrinal publications and related studies that have emerged-prompted largely by the challenges faced there and in Afghanistan-are generally of high quality and evince no obvious shortcomings. Perhaps the most important trait they share is a mandate to take what might be described as a holistic approach to strengthening a partner nation's military. This can mean one of two things or both:

1. Concern for the whole of a nation's civilian and military security establishment, such that one addresses not just basic military capabilities but also the civilian and administrative side of

\footnotetext{
10 Joint Doctrine Note 1-13, 2013, pp. I-2.

11 Joint Doctrine Note 1-13, 2013, p. viii.

12 White House, "Fact Sheet: U.S. Security Sector Assistance Policy,” Washington, D.C., April 5, 2013.
} 
organizing and running security services. This is the focus of SSA and SSR.

2. Concern for the nonmilitary aspects of SFA (and stability operations in general), often in light of the awareness that military conflicts often have political rather than military solutions, and, in many cases, what matters at least as much as a military's ability to provide security is whether or not a regime is legitimate.

Joint Doctrine Note 1-13 makes the DoD's concern with legitimacy very clear. First, it provides a definition of SFA that stresses certain aspects of a military that go well beyond its tactical capabilities. For example, the document defines the goal of SFA as creating FSF that are "competent, capable, sustainable, committed, and confident, and have a security apparatus tied to regional stability." 13 Then, it breaks the definition down further: "Competent" means "across all levels, ministerial to the individual soldier or police officer, or other individuals performing security functions" and "across all functions (operational, enabling, sustaining, and institutional)." ${ }^{4}$ "Capable and sustainable" mean "appropriately sized and effective enough to accomplish missions," as well as "resourced within [host nation] capabilities." 15 As for "committed," the FSF should be committed to:

(a) The survival of the state and security for all its people.

(b) Preserving the liberties and human rights of the citizens.

(c) The peaceful transition of power. ${ }^{16}$

The force should be "confident" in itself and its ability, and, moreover, the citizens should trust that the FSF "will provide security" and also "remain professional" and "conduct their responsibilities within the rule of law." 17 Joint Doctrine Note 1-13 then adds a final character-

\footnotetext{
13 Joint Doctrine Note 1-13, 2013, pp. III-2.

14 Joint Doctrine Note 1-13, 2013, pp. III-3.

15 Joint Doctrine Note 1-13, 2013, pp. III-3.

16 Joint Doctrine Note 1-13, 2013, pp. III-3.

17 Joint Doctrine Note 1-13, 2013, pp. III-3.
} 
istic to the SFA goal, accountability. The FSF should be "accountable" for their "use of power within the framework of rule of law," and citizens should trust that the FSF would "provide security" and "remain professional and accountable." 18 Subsequently, the document gets more specific about its point, namely, the legitimacy of the host nation:

SFA develops FSF that contribute to the legitimate governance of the HN [host nation] population. This is done by developing FSF that are competent, capable, committed, and confident, not only in the eyes of the US, other countries, and HN governments, but more critically, in the eyes of the HN population. Creating the effect of legitimacy is critical to the objectives of SFA. Leaders, planners, and practitioners at all levels who integrate SFA activities into SC planning efforts must consider how each action may affect popular perceptions, and focus activities that enable the legitimacy of the HN government and FSF, not just make them technically competent. While it is important to assist $\mathrm{HN}$ forces to develop professionally, a mirror image US model may not be the optimum solution for some FSF, because of sociocultural factors. Legitimacy may be very tenuous during a complex insurgency, and may be difficult to measure objectively. ${ }^{19}$

In other words, legitimacy is the ultimate objective, and the qualities described-becoming competent and adhering to the rule of laware thought to be attributes of a force that enhance the legitimacy of the state.

A U.S. Army publication, Commander's Handbook for Security Force Assistance (SFA) Brigade and Regimental Combat Team Level (BCT/RCT) in Iraq and Afghanistan, makes a similar case. ${ }^{20}$ First, it defines SFA as "unified action to generate, employ, and sustain local, host nation or regional security forces in support of a legitimate

\footnotetext{
18 Joint Doctrine Note 1-13, 2013, pp. III-3.

19 Joint Doctrine Note 1-13, 2013, pp. III-5.

20 U.S. Army, Commander's Handbook for Security Force Assistance (SFA) Brigade and Regimental Combat Team Level (BCT/RCT) in Iraq and Afghanistan, Kindle ed., Fort Leavenworth, Kan.: Joint Center for International Security Force Assistance, 2013.
} 
authority." 21 It consists, more specifically, of "organizing, training, equipping, rebuilding and advising (OTERA) foreign security forces (FSF)." Among the imperatives of SFA is "build legitimacy." 22 The handbook explains:

The ultimate goal of SFA is to develop security forces that contribute to the legitimate governance of the HN population. This is done by developing foreign security forces that are Competent, Capable, Committed and Confident, not only in the eyes of U.S./ coalition forces and the HN government, but more critically, in the eyes of the HN population. This perceived "legitimacy" is a critical objective of SFA. During early mission analysis and ongoing assessments, planners must determine what factors the $\mathrm{HN}$ population considers in its assessment of the legitimacy of government and more pointedly, [host nation] security forces. SFA leaders and planners at all levels must therefore consider how each operation affects popular perceptions and gear operations to build legitimacy of HN government and security forces. ${ }^{23}$

The current doctrine's emphasis on legitimacy and governance are commendable, particularly in light of critiques of past SFA efforts including, as we will see, Vietnam, where the U.S. military appears to have focused too narrowly on building the Army of the Republic of Vietnam (ARVN)'s war-fighting capabilities while paying little attention to other matters and generally neglecting the issue of governance. That tendency is often thought of in terms of the difference between a conventional force with a conventional mission and a COIN force with a COIN mission. For example, one study of the SFA effort in El Salvador noted that, "up until about 1982, the U.S. security assistance program largely focused on building a conventional force." 24 The United States managed to turn around its own approach to convert the El Salvador Armed Forces into a COIN force, which meant, among other

\footnotetext{
21 U.S. Army, 2013.

22 U.S. Army, 2013.

23 U.S. Army, 2013.

24 U.S. Army, 2013.
} 
things, pursuing a strategy focused less on victory in battle and more on "building government legitimacy by social and economic changes; establishing democratic legitimacy by holding free and fair elections; and ending human rights abuses." 25

These views are of course corollaries of the emerging approaches to stability operations and counterinsurgency in general, as exemplified by Army Field Manual 3-24 Counterinsurgency and Field Manual 3-07 Stability Operations, ${ }^{26}$ which identify politics and political power as the "central issue in insurgencies and counterinsurgencies" and argue that "the primary objective of any COIN operation is to foster development of effective governance by a legitimate government." 27 The Army is asked to help nurture governance, provide basic humanitarian and other services normally associated with governments, and help foreign militaries learn to live within the law and attain a modicum of professionalism, all things that are presumed to foster legitimacy.

\section{Recent Critiques}

While these arguments are compelling, there is room for criticism. For example, Gian Gentile has argued that the entire case for COIN is based on historical narratives that do not hold up to scrutiny: Perceived successes are due to other factors and not the application of COIN methods, while alleged failures often were not what one thinks. ${ }^{28}$ There is also the question of whether or not the approaches outlined with regard to COIN, SA, and SFA, among others, are sufficient even if they are more or less in the right direction. Dafna Rand and Stephen Tankel recently argued that there is still a long way to go before there are

25 Lawrence Cline, "Lessons from the U.S. Advisory Efforts in El Salvador," Security Assistance: U.S. and International Historical Perspectives, The Proceedings of the Combat Studies Institute 2006 Military History Symposium, Fort Leavenworth, Kans., 2006.

26 Field Manual 3-24, Counterinsurgency, Washington, D.C.: U.S. Department of the Army, 2006.

27 Field Manual 3-24, 2006, pp. 1-2, 1-24; Field Manual 3-07, Stability, Washington, D.C.: U.S. Department of the Army, June 2014.

28 Gian Gentile, Wrong Turn: America's Deadly Embrace of Counterinsurgency, New York and London: The New Press, 2013. 
substantive strategies for such goals as instilling professionalism and measuring progress. Despite "the importance of building professional, rights-respecting U.S. partner forces," they write, "currently there is no strategic U.S. approach regarding the 'professionalization' goals of U.S. security assistance." 29 They continue, "U.S. policymakers articulate and expect professionalization outcomes of U.S. security assistance and training but efforts to achieve this goal remains underdeveloped."30 This is unfortunate, for "the 2014 rout of the Iraqi security forces by ISIS [the Islamic State] suggests that no matter how much hardware the United States provides, these professionalization factors can determine whether partner militaries are capable and willing to fight joint threats." 31

Rand and Tankel make a noteworthy consideration with their concern for "will"; however, they, along with current doctrine and theory regarding SFA and COIN, fall short in connecting professionalization with will (i.e., the motivation to stand, fight, kill, and risk being killed on behalf of a government). To be more specific, there is room for questioning the assumption that the qualities SFA and SSA doctrinaires would like to see in a host-nation military force would, in fact, foster legitimacy. Such an argument begs the question of what is legitimacy. It also raises questions concerning the nature of the conflicts afflicting client states and what it would take to rally a preponderance of the population to the side of the regime that is being supported by the United States and sap support for the regime's political rivals. Current doctrine assumes that government legitimacy is won by providing services while not breaking the law or otherwise abusing the population. An army ideally should assist the government with service provision while also obeying the law and not abusing the population. Holding elections is a plus.

The history of nation-building as well as scholarship on revolution leads us to question these assumptions. Service provision and the rule of law may contribute to regime legitimacy, but even if the case

\footnotetext{
29 Rand and Tankel, 2015, p. 12.

30 Rand and Tankel, 2015, p. 12.

31 Rand and Tankel, 2015, p. 12.
} 
can be made for their necessity, they certainly are not sufficient, at least not in the post-French Revolution world of nation-states that derive their legitimacy from more than simple power. Max Weber, after all, ascribed to the modern state the "monopoly of legitimate physical force," not just a "monopoly of physical force." 32 Nor are elections sufficient in the absence of a political culture appropriate for elections and ideologies that support them. There simply is more to establishing a regime's legitimacy and more to a military's role. Similarly, there is more to motivating a military to stand and fight than professionalism.

A clue to the problem with current doctrine can be found in discussions of the definition of an insurgency and the way such terms as revolution and counter-revolutionary are handled. For example, in the highly influential works of David Galula, we find the assertion that most insurgencies of the sort common in the post-World War II world are examples of "revolutionary war," meaning that some group is "challenging a local ruling power controlling the existing administration, police, and armed forces." 33 Galula does not, however, take the idea of "revolution" far. He rejects the idea of describing counterinsurgents as counter-revolutionaries, for the term tends to denote "reactionary" and is often simply not true-counterinsurgents are not counter-revolutionaries, reactionary or not. Galula prefers "insurgents" and "counterinsurgents." 34 This is unfortunate, for the words revolutionary and counter-revolutionary convey more meaning than the more generic terms insurgent and counterinsurgent. Revolutionary, after all, suggests the importance of ideas, identities, and ideologies to an extent that insurgency and counterinsurgency do not. A revolutionary promotes certain ideas. A counter-revolutionary promotes rival ones. Both are locked in a struggle that is, among other things, ideological.

This is not to say that Galula pays no attention to ideology. He places having a "cause" as being at the top of his list for "prerequisites for a successful insurgency," and he also mentions the idea of trying to

\footnotetext{
32 Max Weber, Wirtschaft und Gesellschaft, Tübingen: J. C. B. Mohr, 1922, p. 29.

33 David Galula, Counter-Insurgency Warfare: Theory and Practice, New York: Frederick A. Praeger, 1964, p. xii.

34 Galula, 1964, p. xii.
} 
create a political party to educate local leaders in a "national political movement." 35 That said, he does not dwell on the subject of a "cause" or the insurgents' ideology beyond asserting that, in almost all cases, the counterinsurgent has no real cause or ideology to offer. ${ }^{36}$ What the counterinsurgent can do is simply try to defuse the insurgents' cause by, in effect, giving the insurgents at least some of what they want (i.e., if they are complaining of government abuse, end the abuse), while using military force first to clear insurgents and then to "protect" the population. It should also be noted that Galula offers no parallel list of "prerequisites for a successful counter-insurgency." Might it be easier to generate a list of prerequisites for a successful counter-revolutionary?

\section{Nation-Building and Revolutions}

Many developing states that are potential targets of U.S. SFA today face essentially postrevolutionary circumstances, where a government has been established, but its control over the country remains limited and elements of the previous regime remain important players. The historical literature on nation-building after revolutions can offer many insights into the difficulties these states face and the role their militaries can play in addressing them. Since 1882, when the French philologist Ernest Renan famously defined a nation in terms of "one tangible fact: the consent, the clearly expressed desire to continue living together," students of nation-building have consolidated a consensus around the notion that nations are invented largely through an act of imagination and the embrace of ideas and identities. ${ }^{37}$ Nations are, Benedict Anderson argues, "an imagined political community." 38 Or, in the words of Dominique Schnapper, a nation is a "community of citizens" who share

\footnotetext{
35 Galula, 1964, pp. 13, 59.

36 "The probability is that only one cause exists. If the insurgent has preempted it, then the force of ideology works for him and not for the counterinsurgent” (Galula, 1964, p. 10).

37 Ernest Renan, Qu'est-ce qu'une nation? Paris: Presses Pocket, 1992, p. 55.

38 Benedict Anderson, Imagined Communities: Reflections on the Origin and Spread of Nationalism, London: Verso, 1991, p. 6.
} 
"the idea that there exists a political domain that is independent of the interests of individuals and that they must respect the rules according to which it runs." 39 For Schnapper, building a nation requires the combination of hardware and software: the hardware being state institutions and political practices (e.g., schools and the rituals surrounding elections), and the software being the ideas that provide the content of identities and make the nation feel real and the state legitimate.

Historians of nation-building have demonstrated that, although such factors as cultural and economic integration through roads, railroads, top-down language policies, and market economies have had an important integrative effect on societies and thereby contributed to nation-building, ideas and ideologies have been at least as important. For example, Linda Colley's seminal study of the development of British national identity in the 18th century demonstrates, among other things, the importance of the chronic wars with France and religious movements for unifying an otherwise diverse population. ${ }^{40}$ Caroline Ford, in her work on rural Bretons in the 19th century, and Peter Sahlens, in his work on French communities along the Spanish border, charted the complex processes by which national identities evolved and individuals and social groups defined and redefined themselves, usually as a result of a two-way dialogue or negotiation between top-down influences, usually from the state and local interests. ${ }^{41}$

To understand how new nations are built during and after a revolution, it is helpful to turn to the scholarship on the French Revolution, which examines in great depth and detail several parallel processes, among them:

\footnotetext{
39 Dominique Schnapper, La Communauté des citoyens: Sur l'idée moderne de nation, Paris: Gallimard, 1994, p. 44.

40 Linda Colley, Britons: Forging the Nation 1707-1837, New Haven, Conn.: Yale University Press, 1992.

41 Caroline Ford, Creating the Nation in Provincial France: Religion and Political Identity in Brittany, Princeton, N. J.: Princeton University Press, 1993; Peter Sahlins, Boundaries: The Making of France and Spain in the Pyrenees, Berkeley: University of California Press, 1989.
} 
1. the loss of legitimacy on the part of established authorities, which could be self-inflicted or the work of others

2. the acquisition (or appropriation) of legitimacy by new authorities

3. individuals' redefinition of themselves with respect to the nature of the political community with which they live (i.e., Schnapper's "idea that there exists a political domain that is independent of the interests of individuals and that they must respect the rules according to which it runs" ${ }^{\prime 2}$ ).

Historians of the French Revolution argue that at the center of these processes were language, rituals, and symbols, all of which acted to create new ways of belonging to new, largely imagined communities. They facilitated social integration and legitimized new political authorities and delegitimized others. Lynn Hunt, for example, in her work on the French Revolution, examines how the new nation-buildersthe partisans of the French Revolution-propagated their idea of the nation and community of citizens. "Taking minutes," she writes, "sitting in a club meeting, reading a republican poem, wearing a cockade, sewing a banner, singing a song, filling out a form, making a patriotic donation, electing an official—all these actions converged to produce a republican citizenry and a legitimate government" (Figure 1.1). ${ }^{43}$ Hunt writes,

The political culture of revolution was made up of symbolic prac-
tices, such as language, imagery, and gestures. These symbolic
practices were embraced more enthusiastically in some places and
by some groups than in other places and groups. In many ways,
the symbolic practices-the uses of a certain rhetoric, the spread
of certain symbols and rituals-called the new political class into
existence; talk of national regeneration and festivals of federa-

\footnotetext{
42 Schnapper, 1994.

43 Lynn Hunt, Politics, Culture, and Class in the French Revolution, Berkeley: University of California Press, 1984, p. 72.
} 


\section{Figure 1.1}

The Ritual Planting of a Liberty Tree by French Revolutionaries with Blue, White, and Red Sashes and Cockades and Phrygian Caps

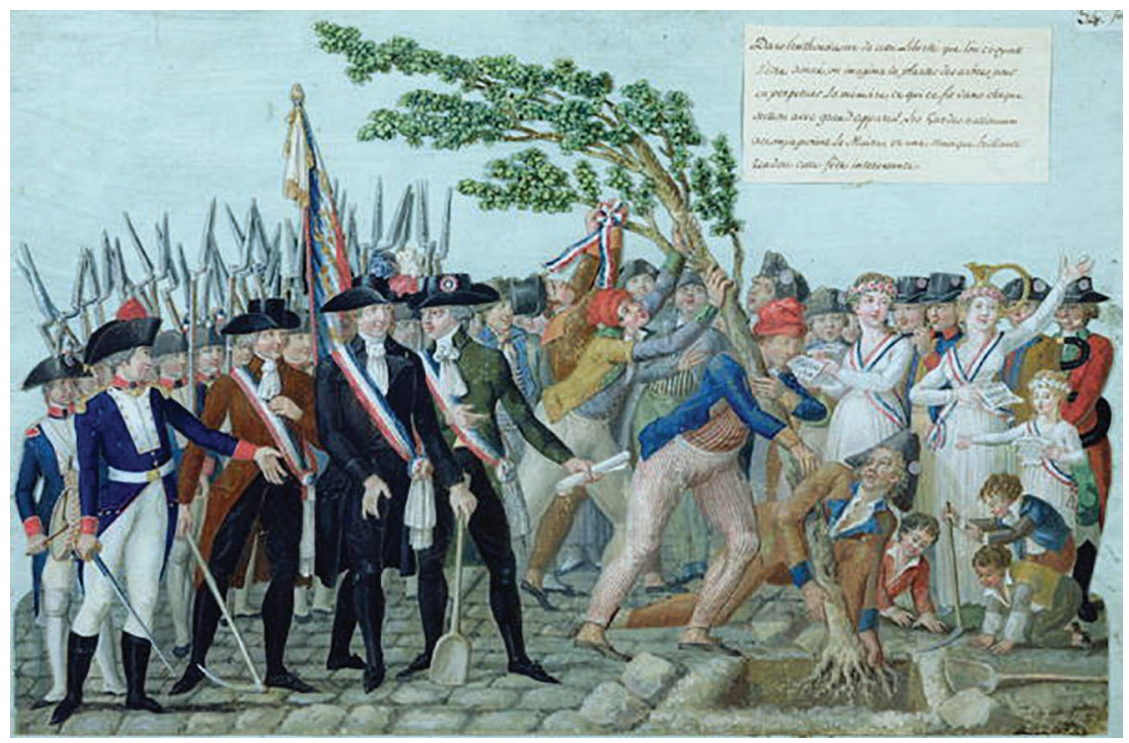

SOURCE: Lesueur Brothers, 18th century, French; Medium: gouache on paper. Date: 18th Century. Perpetuating the memory of Liberty; plantation d'un arbre de la liberte; Provenance: Musee de la Ville de Paris, Musee Carnavalet, Paris, France / Giraudon. Photographic Rights The Bridgeman Art Library.

RAND RR1832-1.1

tion, for instance, gave the new political elite a sense of unity and purpose. $^{44}$

Hunt notes that the political culture of revolution had both symbolic and social sources of coherence. The revolutionaries spoke the same language and sought the same qualities in their symbols and images of authority. They used words, festivals, seals, and measures of time, space, and distance to create a new national identity, making all these things "not a diversion from some more real or important political issue" but essential to the revolutionary process and the search for

44 Hunt, 1984, p. 13. 
a new national identity, one that implied a rejection of all previous models and standards of authority. ${ }^{45}$

A revolution in this light is about more than simply overturning an established regime by force of arms. It also is not about service provision. It is, on the contrary, about creating new identities and redefining people's political community. Armies such as the French Revolutionary army therefore contributed in two different ways. One is that they won. That is, they were competent on the battlefield and defeated the enemies of the revolution. The other is that they reflected and contributed to the ideological or identity aspect of the revolution. It is possible, moreover, that the latter contributes to the former. That is, efforts to make a military an adjunct to the broader goals of the revolution improve its cohesion, morale, and, ultimately, its performance in battle.

This underscores the value of the French Revolution as a point of reference. The Revolution gave birth to a modern nation and signaled the transition from dynastic states to one that derived its legitimacy from the people or the "nation" (in the sense of Renan and Anderson) as opposed to a simple "monopoly of force" (per Weber). Indeed, the pre-1789 French monarchy could be said to have enjoyed a monopoly over the use of physical force, although that was far from its only source of legitimacy, which was rooted in French political culture, custom, and the Church. The monarchy's army was, moreover, nothing more than an instrument of force. As French President Charles de Gaulle put it, the old French army was not "the French army but the army of France." ${ }^{46}$ During the Revolution, the army became an extension of the nation and an embodiment of a national ideal, which, as Clausewitz identified, would be called a "game changer" today, as well as part of the secret of the success of the armies first of the revolution and later of the empire. ${ }^{47}$ Clausewitz writes:

\footnotetext{
45 Hunt, 1984, p. 215.

46 De Gaulle, La France et son armée, vol. 10, in Euvres complètes, Geneva: Edito-Service S.A., 1972, p. 55.

47 For a brief discussion of the paradigm shift represented by the Revolution, see Gunther E. Rothenberg, The Napoleonic Wars, Smithsonian History of Warfare, London:
} 
The war suddenly was once again a thing of the people [often translated as Nation], and a people of 30 million, who all considered themselves citizens . . . with this participation of the people in the war, instead of a cabinet and an army, the entire people with its natural weight stepped onto the scale. Now the means that could be applied, the efforts that could be summoned, no longer had any specific limit. The energy with which the war could be conducted, no longer had a counter-weight and as a result the danger for the opponent was extreme $\ldots{ }^{48}$

And so did the warlike element, free from all conventional limits, break loose with its entire natural power. ${ }^{49}$

The army - and the war itself — played an important role in the process of constructing and projecting regime legitimacy both within the force as well as building an important bridge between the regime and the nation (i.e., the people). The shock, moreover, changed the face of Europe not just by defeating the monarchies that opposed France but also by forcing European countries to initiate reforms needed to match the French by, among other things, drawing the people (nation) into the war and making it their affair, thereby nudging them on the rocky path toward evolving from dynastic monarchies to nation-states.

The militaries of modern nation-states often embody and promote the ideologies of those states or regimes both internally (with respect to how they integrate often very diverse recruits into a cohesive whole unified by shared values and obedience to the larger communities of unit, service, and nation) and externally (in terms of their function as a connection between state and nation and their support for promoting the national ideology and reinforcing the values of the state or the regime). One way to describe such a military is to refer to civic values, ideas about what the community (civitas) is, how one defines it,

Smithsonian Books, 1999, p. 30; William Doyle, The Oxford History of the French Revolution, Oxford: Oxford University Press, 1989, p. 416.

48 Carl Philipp Gottlieb von Clausewitz, Vom Krieg, Kindle ed., Null Papier Verlag, 20122015 , p. 578.

49 Clausewitz, 2012-2015, p. 579. 
and what is regarded as in its interest. The French and, as we will see later in this report, the Malians, fall back on the French word républicain, denoting not just generic civic values but an ideological element, more specifically the ideas identified with the French or Malian republic as opposed to alternative states or forms of government, such as the French monarchy.

Intriguingly, Senegalese leaders, steeped as they are in French political culture, developed the concept of armée-nation (army-nation) to express the idea that the army and the nation should be united, with the army playing a strong supporting role in building the Senegalese nation..$^{50}$ In the first years of their independence, the Senegalese translated this idea into assigning to its army the role of supporting infrastructure programs through its engineering capabilities, boosting the country's rural education system by sponsoring schools, and, perhaps most important, using the military's health services and hospitals to train doctors and place them in public hospitals and clinics throughout the country. According to one commentator, the military's placement of doctors throughout the health care system "reinforced the positive image that the armed forces have enjoyed among civilians," leading to "enhanced popular respect for the armed forces" and contributing to "excellent civil-military relations." 51 It should be noted that the idea of armée-nation appears to be important to the identity of the Senegalese army as well as Senegalese national identity. Such shared beliefs are not organic but rather result from a conscious effort on the part of Senegalese leaders to cultivate the idea within the force as well as the general public.

Whether we choose to speak of an army as civic, républicain, an armée-nation, or perhaps simply a national army, the question is how such a force is built. First, there has to be an idea of the nation and its values (we will return to this point later in this report). An ideology needs to exist that would legitimize the nation, state, regime, or

50 Biram Diop, "Civil-Military Relations in Senegal," in Dennis Blair, ed., Military Engagement: Influencing Armed Forces Worldwide to Support Democratic Transitions, Washington, D.C.: Brookings Institution Press, 2013, pp. 238-239.

51 Diop, 2013, p. 239. 
all three. Effort must be put into promoting that ideology and cultivating it. Conscription certainly helps because it brings into the force a more diverse (and therefore representative) cross section of recruits and usually in much greater numbers than in volunteer or mercenary armies. Conscription also underscores the tie between the military and the nation. However, what militaries do with its recruits as well as how the force conducts itself within the larger society also matters. For example, a recent study of military rituals by Markus Euskirchen examines how rituals serve a dual purpose: one internal to the force and the other external. Internally, military rituals create cohesion and nurture obedience while connecting soldiers to one another and to the new communities into which they are inducted: the unit, the army, and the nation. ${ }^{52}$ Euskirchen argues that military rituals often resemble religious ceremonies in that they tie individual soldiers to values and abstract ideas and ideals (e.g., nation, fatherland, freedom, courage, loyalty), which give their lives meaning and encourage strong feelings of belonging and identification with peers in the ranks. ${ }^{53}$ This is particularly important, Euskirchen argues, given that soldiers face the "fundamental problem of killing and being killed." ${ }^{44}$ Euskirchen also notes that modern nations have always leaned on their militaries and the ceremonies and rituals associated with them to project and demonstrate their power. "Where there is state rule, there are military ritu-

52 Markus Euskirchen, Militärrituale. Die Ästhetik der Staatsgewalt: Kritik und Analyse eines Herrschaftsinstruments in seinem historisch-systematischen Kontext, Berlin: Freie Universität Berlin, 2004.

53 Euskirchen, 2004, p. 14. His comments about the religious nature of military ceremonies are reminiscent of Lynn Hunt's remarks in the forward to Mona Ozouf's study of the revolutionary festivals of the French Revolution. Hunt writes:

Here Ozouf is following the lead given by Emile Durkheim in his influential study, The Elementary Forms . . . Durkheim argued that the essential function of religion was to provide social solidarity. Religion was society's way of making itself sacred; religion created the emotional bonds that made people obey social rules willingly. No society could exist without this sense of its sacredness. All societies set themselves up as gods ... they give these gods different names, but they all serve the same social purposes (Mona Ozouf, Festivals and the French Revolution, Cambridge, Mass.: Harvard University Press, 1988, p. xi).

54 Euskirchen, 2004, p. 14. 
als that demonstrate and celebrate the power of this rule," Euskirchen writes. ${ }^{5}$ Indeed, he argues, military rituals should be regarded as "rituals of power." 56

Again, the French Revolutionary army provides an iconic example. Following the Revolution, the French army faced two problems. One was that the army was not in a condition to face off against the array of professional armies committed to restoring the French monarchy. A significant portion of the country's predominantly aristocratic officers resigned, fled the country, and, in many cases, defected. According to De Gaulle, by the end of 1792, 5,000 of the army's original 9,000 officers had left the ranks. ${ }^{57}$ Soldiers could not be relied on to follow their commanders' orders; the commanders could not be relied on to be loyal to the Revolution or the government. Desertions and soldiers turning on their officers were common occurrences in early clashes on France's borders. ${ }^{58}$ The leaders of the Revolution, moreover, were ill at ease with the army because they saw it as a creature of the aristocracy and the embodiment of forms of hierarchy and subordination that were fundamentally at odds with the kind of egalitarianism they sought. To complicate matters, the French army rapidly became a hybrid force that paired holdover professionals with successive waves of recruits-some enthusiastic volunteers and later conscripts. The revolutionary army launched large-scale recruitment drives to rally partisans of the Revolution and harness their determination to protect the Revolution and advance its agenda; it then conducted mass conscription-the famous levée en masse of August 1793 - that embodied the new idea of the nation at arms. (The generally high rate of compliance with the conscription laws of the 1790s, it should be noted, reflects the

\footnotetext{
55 Euskirchen, 2004, p. 26.

56 Euskirchen, 2004, p. 26.

57 De Gaulle, 1972, p. 87. See also Doyle, 1989, p. 156.

58 Doyle, 1989, p. 184.
} 
progress of that idea: The nation called, and most local administrators and most young men complied. ${ }^{59}$ )

The second problem was the larger political work of consolidating the Revolution and promoting its efforts to reform society. Faced with a foreign invasion - which included French officers and aristocrats who sought to overturn the Revolution and reinstate the monarchy-and a large-scale domestic insurgency rooted in regional traditions of resistance to the central state and Catholic piety, the success of the Revolution was never a foregone conclusion, and even the support of a sympathetic population could not be considered a given when the new regime in Paris was demanding growing sacrifices.

The government dealt with both problems by making a concerted effort to indoctrinate the force politically, integrate its disparate parts into a cohesive and unified whole that was dedicated to its new identity as the nation at arms, and cement the ties between the people, the army, and the new regime. Among other things, the government strove to replace regimental with national identities. To efface the line between the professional army and the new recruits, the regime tried to integrate the two forces by placing two volunteer battalions with one regular army line battalion in a single, unified demi-brigade. This tactic discouraged unit-centered identity and pride and encouraged the promotion of national identity and patriotism, which the government saw as good for the army and for the republic. ${ }^{60}$ The government imposed on all regiments the same uniforms, the same flags, and the same pay.

Similarly, the government fostered integration and promoted French language use (rather than such regional dialects and languages as Alsatian, Breton, or Occitan). The French military historian JeanPaul Bertaud notes that the nascent republic took seriously the idea of

59 Annie Crépin, Vers l'armée nationale: Les débuts de la conscription en Seine-et-Marne, Rennes, France: PU Rennes, 2011.

60 Jean-Paul Bertaud, La révolution armée: Les soldats-citoyens et la Révolution française, Paris: Éditions Robert Laffont, 1979, pp. 194-195; Rothenberg, 1999, pp. 30-31; Gunther E. Rothenberg, The Art of Warfare in the Age of Napoleon, Bloomington, Ind.: Indiana University Press, 1980, pp. 102-105. 
the army being a national melting pot. ${ }^{61}$ France's military units tended to have disproportionate numbers of people from the local region, but none exclusively comprised a single group. French language was taught in all units. To become a corporal, sergeant, or officer, French law dictated that one needed to be literate in the national language. In addition to promoting a national identity, establishing a lingua franca that all troops understood would result in clear operational benefits on the battlefield.

The Republic's program included the following:

1. Political commissars. The government (the Convention regime) sent political agents to field units to monitor and discipline them but also to teach and inform the troops and to disseminate information. They also wrote back to Paris for help taking care of the troops and attempted, through their support for them, to translate the revolution into reality. ${ }^{62}$

2. Written propaganda. The regime made heavy use of newspapers and other mass press to disseminate information and ideas to the troops. ${ }^{63}$

3. Propaganda songs. Because songs were considered the best way of spreading political ideas among the troops, the Convention and its political allies collected, printed, and distributed revolutionary songs. ${ }^{64}$ The best-known song of the revolution is, of course, "La Marseillaise," which calls on the people of France to take up arms to defend the nation, identified with liberty, against foreign agents of tyranny and monarchs.

4. Formal indoctrination. The government subjected troops to classes, lectures, and theatrical performances to propagate its ideology. ${ }^{65}$

\footnotetext{
61 Bertaud, 1979, p. 176.

62 Bertaud, 1979, p. 195.

63 Bertaud, 1979, p. 215.

64 Bertaud, 1979, pp. 148-151.

65 Bertaud, 1979, pp. 200-201.
} 


\section{Ceremonies, festivals, and parades.}

Ceremonies, festivals, and parades were common tools of political indoctrination during the Revolution. They brought soldiers together with the citizenry and representatives of the revolutionary government to conduct ceremonies involving a new canon of rites and symbols associated with the Revolution and its values such as dancing around liberty trees, singing "La Marseillaise," and burning traitors in effigy. ${ }^{66}$ There were ceremonies designed to strengthen the ties between volunteers and regulars, as well as ceremonies intended to foster ties between civilians and the military. ${ }^{67}$ In all cases, they were intended to foster identification with the republic and the postrevolution state. "The intimate union of the nation with its army was the idea that predominated at these festivals." "68 A new tradition of "federation festivals" emerged soon after the Revolution, usually featuring soldiers of some kind and representatives of specific regions who took oaths of loyalty to the Revolution.

The most famous festival was the massive Festival of Federation held on July 14, 1790 (see Figure 1.2).69 The ceremony featured the army and the Paris National Guard (whose blue, white, and red colors were borrowed by the Revolution as a whole), led at the time by none other than the Marquis de Lafayette, the hero of the American Revolution and icon of French republicanism. Lafayette, in a ritual replete with religious elements, led the troops in the taking of an oath of loyalty to the new Constitution (see Figure 1.3).

In subsequent years, the army as well as the Guard, often together, joined civilians in reenacting the Paris festival to cement their unity and their loyalty to the new nation.

\footnotetext{
66 Bertaud, 1979, pp. 205-206; Rothenberg, 1980, p. 104. Rothenberg describes ceremonies developed whenever new units were formed, including the presentation of flags and the singing of "La Marseillaise."

67 Bertaud, 1979, p. 152.

68 Bertaud, 1979, p. 26.

69 The seminal study of the revolutionary festivals is Ozouf, 1988.
} 
Figure 1.2

The Federation Festival Commemorating the Anniversary of the Fall of the Bastille and the Unity of the French People, Held at Paris, July 14, 1790

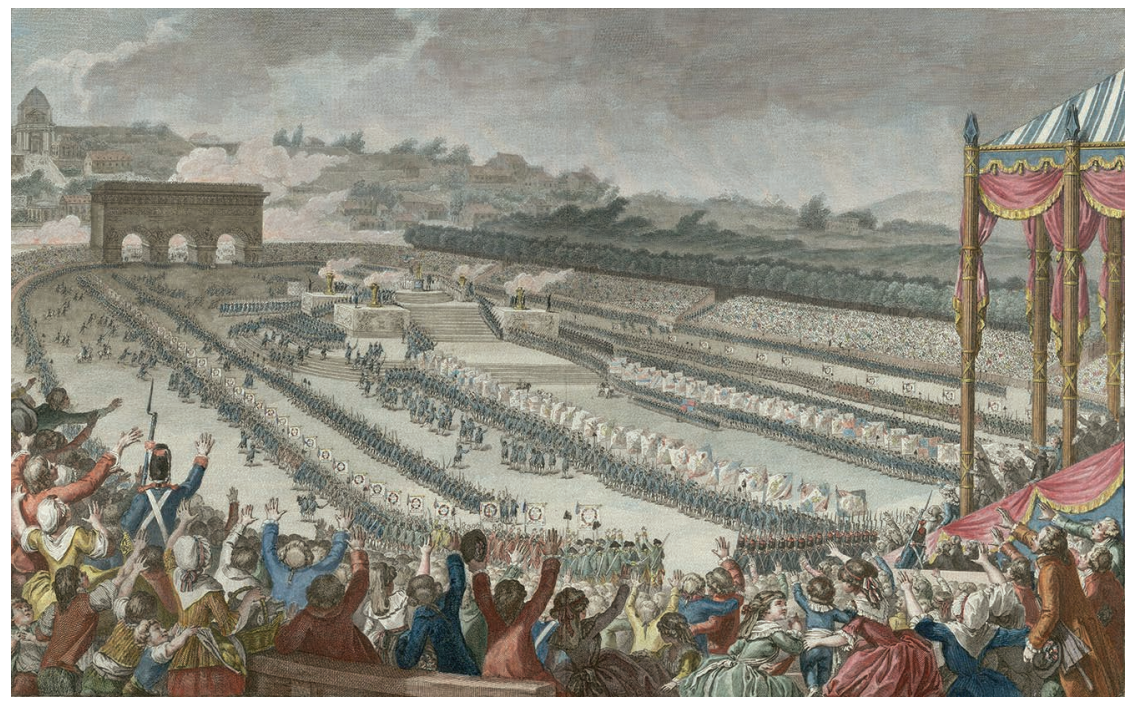

SOURCE: Isidore Stanislas Helman [Public domain], via Wikimedia Commons. RAND RR1832-1.2

The use of armies to foster specific national identities and tie people to an idea of a nation and a regime in an effort to legitimize a state is not peculiar to revolutionary France. Another famous example is the Israeli Defense Forces (IDF), which, from the beginning, has been at once an instrument of national security and a tool for national integration, with the understanding that the two tasks were mutually reinforcing. ${ }^{70}$ Through an array of methods, the IDF has actively worked to function as a melting pot for immigrants and a crucible of national identity. It is where countless first- and second-generation Israelis have learned the national language, socialized with one another, become familiar with the land of Israel, and-through participation in such ceremonies and rituals as those held at the Western Wall or Masada (sites charged with

70 William Darryl Henderson, Cohesion: The Human Element in Combat, Washington, D.C.: National Defense University Press, 1985. 
Figure 1.3

The Oath of La Fayette (Wearing the Blue, White, and Red Uniform of the National Guard, Which Became the Colors of the Revolution) at the Federation Festival, July 14, 1790

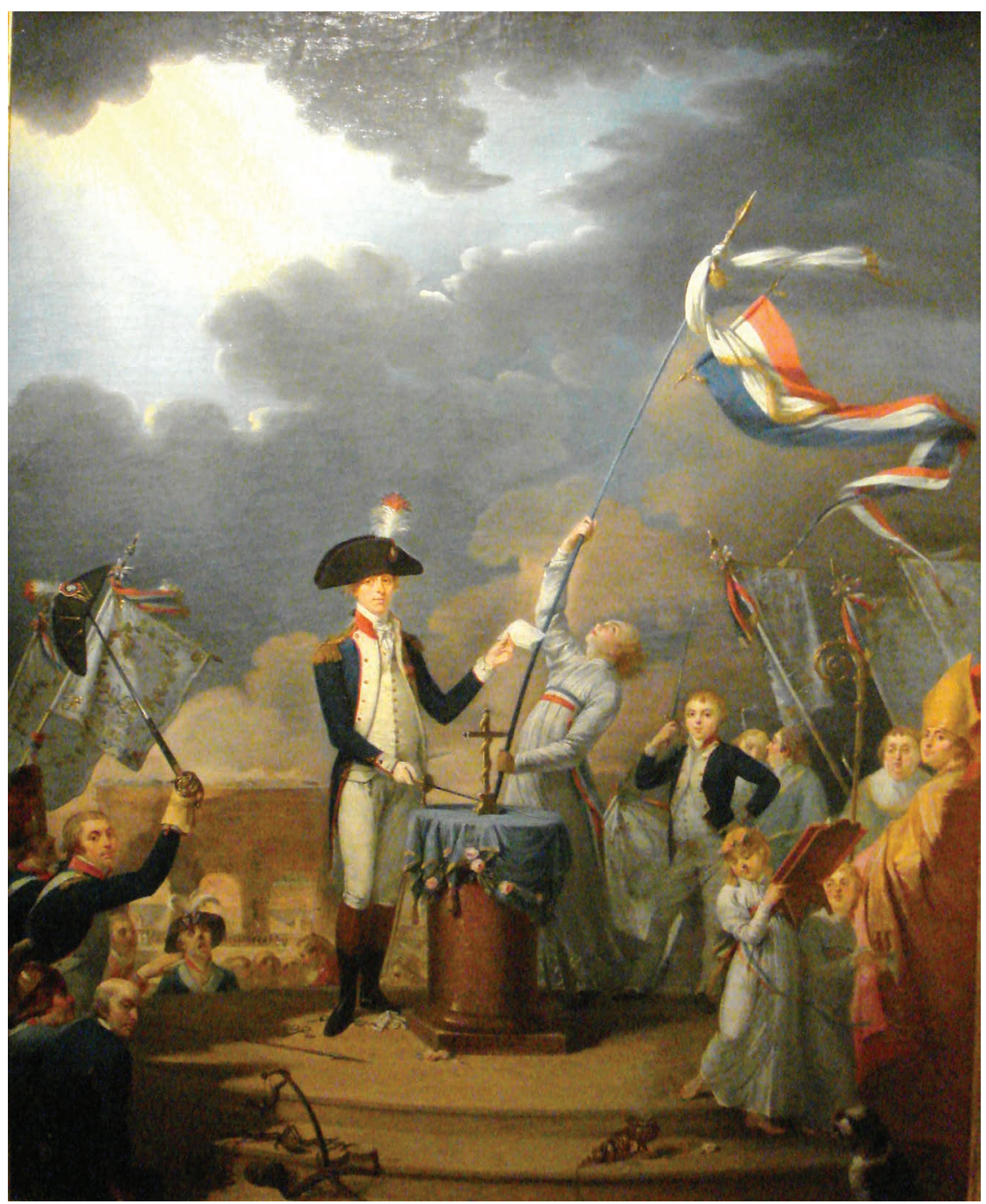

SOURCE: By Unknown (French art) (Own work PHGCOM) [Public domain or Public domain], via Wikimedia Commons.

RAND RR1832-1.3 
Figure 1.4

The IDF's Givati Brigade Participating in Evening Prayers at the Western Wall, the Symbolic Focal Point of the Jewish People

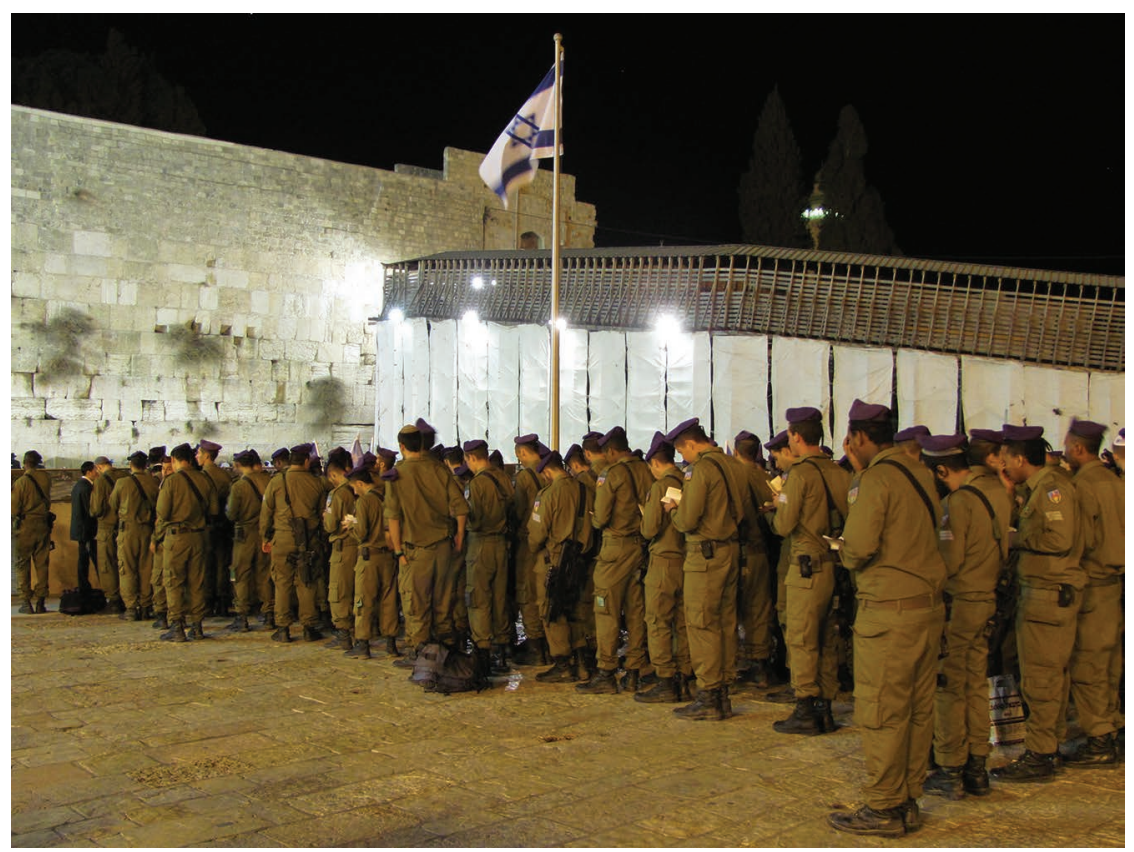

SOURCE: By Yoninah (Own work) [CC BY-SA 3.0

(http://creativecommons.org/licenses/by-sa/3.0) or GFDL

(http://www.gnu.org/copyleft/fdl.html)], via Wikimedia Commons.

RAND RR1832-1.4

symbolic historical and religious meaning)—become initiated in the nation's national myths (Figure 1.4).

A more recent study of the IDF similarly emphasized that the force's integrative function not only cultivates national identity and the army's legitimacy but also is crucial for the force's effectiveness and arguably the nation's survival. Referring to the IDF's "management of diversity," the authors note that, in Israel's case, the armybesides being "an entryway into normative Israeliness and the epitome of citizenship" — "forms a key symbolic form for identification beyond 
social cleavages and conflicts." ${ }^{11}$ Moreover, they argue, the IDF "has to constantly maintain its legitimacy through showing that it is a people's army." It is a conscript army, meaning that, technically, it compels service, but it cannot be as strong as it is unless it "carries the meaning of belonging to and partaking of a common fate in the collective" and constantly maintains its "symbolic capital." The IDF, they argue, does more than simply address the needs of the group or manage diversity for the sake of ensuring unit cohesion. It has to, through its practices, "defend the moral boundaries of the national collective" and "civil consciousness" by integrating women, minorities, and religious and secular citizens, but also by building a basis of identification.

The authors also make an intriguing distinction between how the IDF "manages diversity" and how it is done by "industrial democracies," a term we take to mean established democratic societies such as the United States and the countries of Western Europe. There, the authors argue, the purpose of "managing diversity" is about improving effectiveness or identity politics. In Israel, it is "done primarily to create and maintain the symbolic and moral boundaries of the Jewish people and the State of Israel."72

Another contemporary example is the German Bundeswehr. Since the re-establishment of their armed forces following World War II, the Germans have taken great pains to use the Bundeswehr as an instrument of nation-building designed to promote a very specific idea of the Federal Republic. They try to highlight historic continuity, in part by referencing pre-Nazi German and more specifically Prussian traditions (e.g., ceremonies, icons, songs), while dealing with the Nazi period by focusing explicitly on anti-Nazi resistance and the idea that the German army under the Nazis broke its oath-something today's Bundeswehr pledges not to do. These notions are on display once a year, when the German army's Wachtbataillon, which is itself a legacy

\footnotetext{
71 Edna Lomsky-Feder and Eyal Ben-Ari, "Performing the People's Army: The Israeli Military Manages Symbolic and Moral Boundaries," in Fran Markowitz, Stephen Sharot, and Moshe Shokeid, eds., Toward an Anthropology of Nation Building and Unbuilding in Israel, Omaha: University of Nebraska Press, 2015.

72 Lomsky-Feder and Ben-Ari, 2015.
} 
of the Prussian era and upholds the Germans' highest standards with respect to ceremonial parade ground precision and protocol, conducts the Gelöbnis - or oath-taking — ceremony by new recruits.

The Gelöbnis takes place on July 20, the date of the failed assassination attempt against Adolf Hitler by a number of German army officers. Thus, on that day, German recruits swear, "Ich gelobe der Bundesrepublik Deutschland treu zu dienen und das Recht und die Freiheit des deutschen Volkes tapfer zu verteidigen" ("I swear to serve the German Federal Republic faithfully and bravely to defend the Right and the Freedom of the German peoples").73 At the Gelöbnis held in 2014, the 70th anniversary of the assassination attempt, Minister of Defense Ursula von der Leyen opened the ceremony by noting the presence of religious leaders (she mentioned, by name, the presence of the head of the German Jewish community - the only religious leader to be mentioned by name) and talked at length about the German army's failure to be true to its honor in the past. ${ }^{74}$ She was followed by Berhold Schenk Graf von Stauffenberg, the son of Claus Schenk Graf von Stauffenberg, one of the German army officers behind the assassination attempt (who was executed soon after). His speech, too, was about German honor and the call bravely to defend Germans' freedom. The music accompanying the ceremony was pure Prussian military, with the exception of the German national anthem ("Deutschland über Alles"), which, like the German black, red, and gold flag, refers back to the 19th-century liberal nationalist movement, the historic strand of German nationalism with which the Bundesrepublik prefers to identify itself), and Beethoven's "Ode to Joy," now identified as the European anthem. ${ }^{75}$ In other words, the Germans crafted the ceremony to promote a specific narrative of the nation and its history, of the proper rela-

\footnotetext{
73 Euskirchen, 2004, p. 86.

74 “Feierliches Gelöbnis der Bundeswehr 2014 (German TV Broadcast)," YouTube video posted by user Winnie9212, February 14, 2014.

75 The music played at the 2014 Gelöbnis included "Preußens Gloria mit Locke" (Prussian Glory March), the "Präsentiermarsch" (Presentation March), written by none other than King Friedrich Wilhelm III, the "Des Großen Kurfürsten Reitermarsch" (Great Prince Elector's Cavalry March) by Graf von Moltke, and "Marsch aus der Zeit Friedrich des Großen," or "March from the Time of Frederick the Great."
} 
tionship between the government and the people, and the army's relationship with both. The narrative arguably is convoluted and certainly selective with regard to Germany's past, but it nonetheless is crucial for the Bundesrepublik's legitimacy. As Euskirchen puts it, the state, which is the "realization of the ethical ideal" (per German philosopher Georg Wilhelm Friedrich Hegel), is made real through its public "staging" (Inszenierung). ${ }^{76}$ That is, in effect, an important role played by the armies of modern nation-states.

It is also worth noting the Germans' concern with emphasizing the ties between the military and the people, both because of historic abuses but also because of the more immediate concern that having only recently abolished conscription, German's new all-volunteer force risks becoming estranged from the German public. The speeches we cite that were given at the 2014 Gelöbnis raised the issue explicitly. One finds numerous other examples: The Bundeswehr's current slogan, "Wir. Dienen. Deutschland." (We. Serve. Germany.), should be read as emphasizing the "we," (i.e., "we" are "you," "we serve you"). The same is true for the German army's slogan, "Wir sind das Heer!" (We are the army!)

\section{Revolutionaries and Counter-Revolutionaries}

If states or regimes establish their legitimacy in part through the projection of ideas and the shaping of identities — and if armies play an important role therein - a number of things follow. First, as mentioned, having a cause-or, better yet, an ideology—is a prerequisite for the counterinsurgent as well as the insurgent. In the French case, the revolutionary insurgents had a clear ideology that enabled them to topple the established order-which had its own ideology but failed to see it prevail; thereafter, counter-revolutionary insurgents struggled to topple the now-established revolutionary regime by promoting an arguably more militant version of the original ideology, one designed to mobilize local solidarities (in conflict with the central government)

76 Euskirchen, 2004, p. 29. 
Figure 1.5

A French Catholic Counter-Revolutionary with White Cockade (the Color of the Monarchy) and Sacred Heart Badge, Symbol of Piety

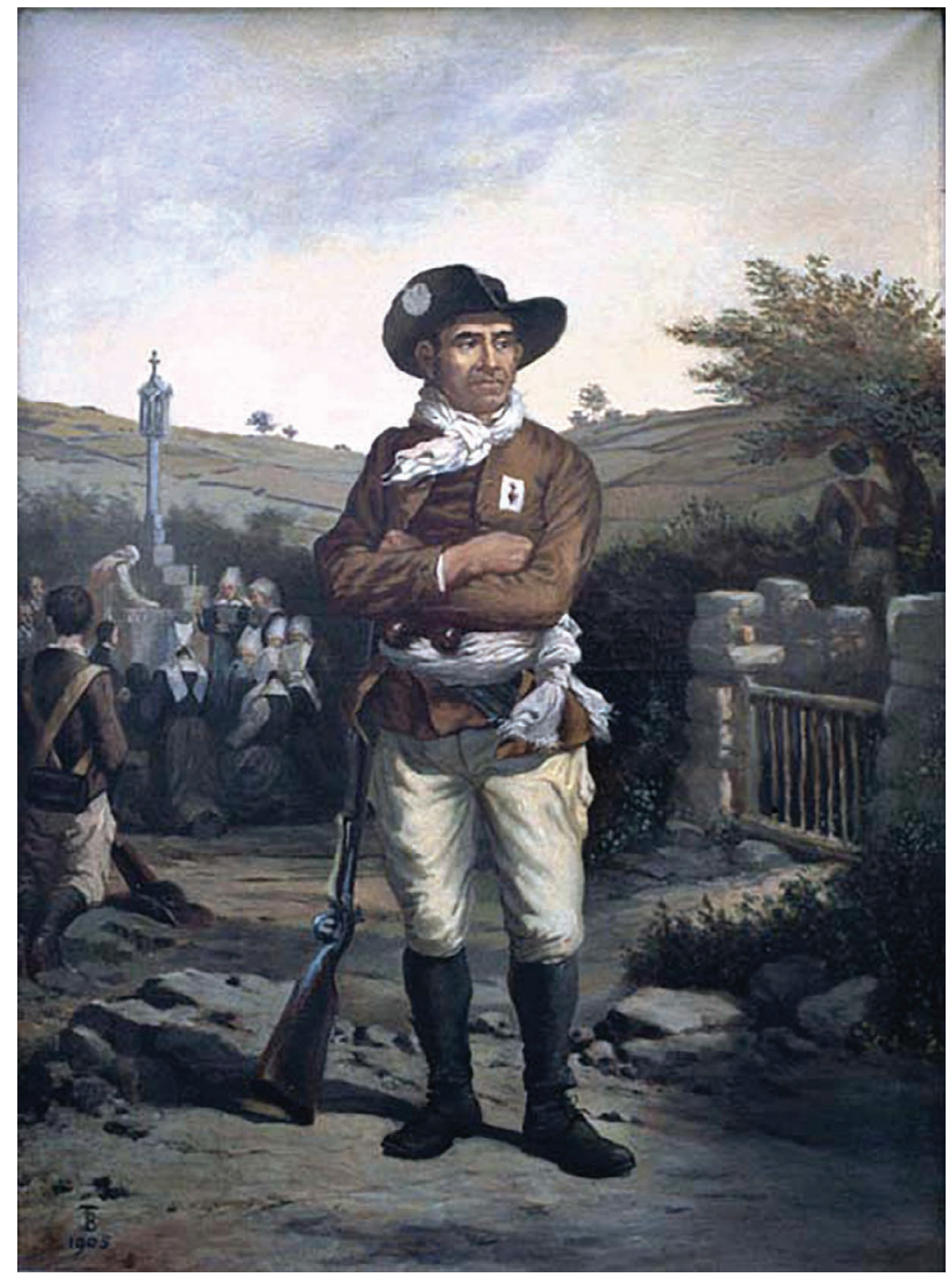

SOURCE: By Théophile Jean Marie Busnel (presbytère de Bignan) [Public domain], via Wikimedia Commons.

RAND RR1832-1.5 
but above all deep-seated Catholic fervor. ${ }^{77}$ The two sides engaged in a bitter civil war that lasted for years and would erupt now and then over the course of the next two centuries. The conflict was part military, of course, but it was also ideological, as the two fought to promote rival interpretations of what it meant to be a French patriot and a Christian (Figure 1.5). Ultimately, however, the identities and ideologies forged by the revolutionaries prevailed. French identity today is defined by the Revolution far more than the crown and the cross; French soldiers today salute the colors of Lafayette's National Guard, while the iconography of the Catholic counter-revolution is nowhere to be seen. Similarly, the fact that no one today questions the German Federal Republic's use of the flag of the Revolution of 1848 suggests the success of a long process of promoting certain ideas and narratives over others.

Of course, for an army to have an ideology, the state and nation it serves must have one. The army clearly cannot be the only instrument of the Inszenierung of the idea of state and of promoting and projecting state legitimacy. Bundeswehr rituals, for example, cannot be given credit for the legitimacy of the Federal Republic. Rather, the Bundeswehr's contribution works as a complement to a broader effort involving the entire state apparatus as well as the collaboration of opinion leaders and all those who have contributed to shaping German political culture, from kindergarten teachers to university professors and journalists to bureaucrats. The fact that the Bundeswehr so consciously acts to promote the national identity and ideology of the Federal Republic is indicative of the existence of the larger nation-building project that has been underway since World War II. If the Bundeswehr made no such effort, it probably would be evidence of the absence of that larger project and a strong indication that the Federal Republic had no ideology to offer, with troubling implications for the government's long-term stability if the state faced a serious challenge.

The possible implication for SFA is that those assessing a host nation's needs and its potential for assistance should consider the extent to which its force engages in promoting state ideology, the extent to

\footnotetext{
77 For a brief description of France's counterinsurgency campaign during the Revolution, see Rothenberg, 1980, pp. 118-120.
} 
which the host nation attends to the relationship between the force and the people, and whether or not there is a larger nation-building effort. A nation might have a national ideology and a nation-building effort designed to promote it, but might make little use of its military to assist in the effort. Such a nation might be influenced to avail itself of the opportunity its force represents and learn to use its military better in this regard. A nation might have a weak national ideology or none at all, or it might make little effort to promote it, instead privileging regional or sectarian identities. Such a nation would be at a significant disadvantage with respect to countering an insurgency-raising concerns about how much SFA can do to build an effective force under these circumstances.

\section{Ideology and Cohesion}

As just discussed, militaries' attention to ideology may offer valuable advantages within the force itself with respect to cohesion and soldiers' identification with the larger nation they serve. Euskirchen describes military rituals, for example, as taking place in the context of the overall process of indoctrinating recruits into an entirely new set of solidarity groups with which they identify and to which they offer their obedience. He writes of the military as a "total institution" that produces obedience through shared hardship, hazing, the imposition of new norms through myriad rules and regulations, and drills, including the rituals that also serve to impart identification with larger ideas. ${ }^{78}$

Whether ideology — as opposed to simple cohesion-contributes to greater effectiveness is not clear; there is some evidence, however, that the sense of purpose it contributes helps. In the case of the French Revolution, ideology appeared to be a factor inciting shared values, as well as contributing to French identity long after the fighting was over. ${ }^{79}$ Some studies ascribe to the soldiers' ideological motivation and

\footnotetext{
78 Euskirchen, 2004, p. 56.

79 This judgment can be found in Histoire de L'armée Française 1789-1870, YouTube video by user Nano GFL, November 25, 2012; Jean-Paul Bertaud, Valmy: La démocratie en armes,
} 
associated esprit de corps some of the credit for the French army's transformation into an effective force and their battlefield successes. In reality, the contribution of ideology and identity might not be as great as that suggested by the romantic mythology that has grown up around the "Army of the Year II" in French Republican tradition-the version one finds in De Gaulle's history of the French army or, before him, Jean Jaurès's stirring L'Armée Nouvelle-but the contribution undoubtedly was significant. ${ }^{80}$ We have already seen Clausewitz's view of the power of fielding an army backed by the weight of the people; enthusiasm (along with overwhelming numbers and expert artillery) is said to have made an important contribution at the battle of Valmy, to give one example. There, French infantry charged to cries of "Vive la Nation!" and the singing of the revolutionary song, "Ça ira." According to Doyle, the army fought with a determination and enthusiasm that had not been seen on European battlefields for generations, and Goethe, who witnessed the battle, told the defeated Prussians, "Here and today, a new epoch in the history of the world has begun, and you can boast you were present at its birth." ${ }^{11}$

William Darryl Henderson surveyed postwar studies of the Wehrmacht and other forces, namely the view that small-unit cohesion is ultimately the key to military performance. Henderson notes that, in general, there are three approaches to motivating and controlling troops: coercive control, utilitarian control (e.g., incentivizing through food, pay), and "normative control." 82 The last, which Henderson regards as most effective for modern militaries, refers to generating strong personal and moral commitments through intensive socialization that encourages the individual to conform to unit expectations

Paris: Gallimard, 1970; Bertaud, 1979; Alan Forrest, The Legacy of the French Revolutionary Wars: The Nation-in-Arms in French Republican Memory, Kindle ed., Cambridge: Cambridge University Press, 2009.

80 The mythology of the "Army of the Year II" as found in de Gaulle's history of the French army or, before him, Jean Jaurès's L'Armée Nouvelle. For a study of the mythology of the army of the revolution in French Republican tradition, see Forrest, 2009.

81 Doyle, 1989, p. 193.

${ }^{82}$ Henderson, 1985, pp. 22-23. 
"even when separated," or when acting as such is contrary to individual preference. ${ }^{83}$ The small unit, Henderson argues, is both the focus and locus for the kind of socialization and resocialization required to foster the kind of normative control that translates into strong cohesion and, thus, strong performance. It is largely a process of creating new solidarities and identities through various means, among them numerous forms of indoctrination, education, rituals, and symbols, but also simply shared hardships, particular pay and leave policies that reinforce certain behaviors and perspectives, and, in some cases, methods of policing behaviors and ensuring that people do not identify with outsiders or subgroups that encourage deviance.

Henderson acknowledges that much of the scholarship on smallunit cohesion dismisses ideology or politics as drivers of cohesion and combat effectiveness. German troops in World War II reportedly fought well because of their particularly strong degree of small-unit cohesion, which had nothing to do with Nazism, German war aims, or even nationalism. However, in a series of case studies that look at the American, Israeli, North Vietnamese, and Soviet Armies, Henderson argues - particularly with regard to the IDF and the North Vietnamese Army (NVA) — that it is important (although admittedly difficult) to measure the degree of common culture and values, as well as strong identity with the nation and thus, on some level, the militaries' war aims. Henderson observed the Vietcong in a separate study:

[s] ociopolitical factors such as ideology ... national symbols, legends, and causes such as a common awareness and resentment of the "nation's" colonial history also contributed to primary group cohesion. [Vietcong] indoctrination met with varied success in inducing individual commitment to secondary group symbols by establishing preconditions for primary group membership. Secondary group sociopolitical symbols that supported [Vietcong] war objectives to some degree became primary group norms. ${ }^{84}$

\footnotetext{
83 Henderson, 1985, p. 23.

84 William Darryl Henderson, Why the Vietcong Fought: A Study of Motivation and Control in a Modern Army in Combat, Westport, Conn.: Greenwood Press, 1979, p. 130.
} 
According to Henderson, the Vietcong indeed had to meet the basic individual needs of its soldiers, but building the level of cohesion required to perform effectively in the face of U.S. firepower required the manipulation of cultural traits, national identity, and sheer patriotism to reinforce cohesion and identification with the nation and its war aims while neutralizing potentially divisive traits and factors. ${ }^{85}$ It involved writing and rewriting Vietnamese history, for example, and promoting identities that strengthened cohesion within the unit and between the unit and larger entities (i.e., the army as a whole and the state it serves). In the case of the Vietcong, Henderson noted, it was the unit commander who did the work of bridging the unit to the larger whole and ensuring that the unit's values reinforced the larger projects of building the nation and winning the war.

\section{Conclusion}

We argue that current approaches to SFA—and arguably COIN and U.S. nation-building abroad-neglect the relationship between building militaries and building nations, which involves forming identities, promoting ideologies, and encouraging legitimacy through means that often have little to do with simply imposing a monopoly of violence or protecting populations, however important that might be. This arguably reflects a larger failure to appreciate the importance of ideas, identities, and ideologies for nation-building in general and, more particularly, the development of legitimacy. Instead, the SFA focus has been on technical matters and force structure-at most service provision or security. SFA that limits its focus to technical or tactical capabilities — readiness according to the standard metrics — risks missing the point, as does any aid provided to any client state that focuses on a state's ability to provide services or the technical functioning of state administrations. However, as much as an army must be competent, it may also have to be civic, républicain, or an armée-nation in the sense that it complements a larger nation-building project.

85 Henderson, 1979, pp. 137-139. 
The next chapters explore these issues through a series of case studies. The first three are historical examples of large-scale U.S. SFA efforts on behalf of beleaguered regimes, the Republic of Korea (ROK), the Republic of Vietnam, and post-2003 Iraq. Additional case studies examine the relationship between militaries and the development of national identity in three fragile postcolonial African states: Ghana, Mali, and Nigeria. 


\section{The Army of the Republic of Korea and the U.S. Advisory Mission}

The Army of the Republic of Korea (ROKA) and the U.S. SFA program in Korea are widely regarded as successes that contrast sharply with events in Vietnam or, more recently, Iraq. The topic begs the question of what went wrong in the latter cases or what went right in the Korean case. Unfortunately, there are too many differences between Korea and Vietnam to be able to attribute success or failure to one or even several factors. That said, there appear to be two distinctive features in the Korean case that merit highlighting because they probably contributed to its relative success. One is the conscious and effective effort on the part of the ROK civilian and military leadership to elaborate and promote a specific national identity and ideology, one that reinforced state legitimacy and helped the young republic overcome significant challenges. They did this in the context of a robust and comprehensive nation-building effort with a particular emphasis on economic development, but also on education and other sectors that, among other things, have contributed to the ROK's current prosperity. The second feature is the attention paid by the U.S. advisors to the Korean military's identity and ideology as part of a broader nation-building strategy. Koreans were already cultivating this aspect into their nation-building strategy, but the United States encouraged the ROK by trying to direct their efforts and helping them build associated content into soldiers' education and professional training. This chapter provides an overview of this history of Korea, Korean and U.S. 
approaches to nation-building, and, finally, the history of ROKA and the U.S. advisory mission.

\section{A Nation Contested, 1945-1950}

What must be stressed with regard to Korea's first decade following its liberation from Japan in 1945 is the extreme fragility of the ROK, its lack of any inherent legitimacy, and the viability of hostile, rival ideologies and movements that threatened the regime. Indeed, as the historian Bruce Cumings has amply documented in his seminal The Origins of the Korean War and other works, the war between North and South Korea in 1950-1953 was part of a larger civil war that began in 1932 and has never ended, a war that killed more than 100,000 people in South Korea even before the northern invasion in $1950 .{ }^{1}$ The war boiled down to a social conflict between and among Koreans from and for different social strata who contested or defended the domination of a small number of elite land owners over a vastly greater mass of impoverished people. In general, the elites tended to have collaborated with the hated Japanese, which diminished their legitimacy significantly post-1945. Those who wanted reforms often were attracted to leftist platforms of diverse types, and communists, although not necessarily popular, at least benefited from anti-Japanese credentials. Moderates, although not communist, often sympathized with North Korea and even chose it over South Korea, which, to them, did not necessarily offer a better choice: Both Koreas were oppressive, while one-in some Koreans' eyes - at least offered to correct profound social inequalities. ${ }^{2}$

U.S. occupation authorities, through a combination of ignorance, pragmatism, and an aversion to anything that looked leftist, handed the Japanese-run police and state to the Korean far right, which worked systematically to shut down the reformist movements that briefly flour-

\footnotetext{
1 Bruce Cumings, The Korean War: A History, Kindle ed., New York: Modern Library Chronicles, 2011.

2 Bruce Cumings, The Origins of the Korean War, Volume II, Princeton, N.J.: Princeton University Press, 1990, p. 222.
} 
ished after the Japanese surrender, and imposed an order that served the elites' class interests. The fact that so much of the post-liberation bureaucracy and security forces were veterans of the Japanese system was no trivial matter, according to Cumings. It defied most Koreans' desire for independence and underscored for many the undesirability of the regime that was emerging under direct American auspices. ${ }^{3}$ The United States also brought to Korea from exile Syngman Rhee and set him atop the Korean state. Cumings describes Rhee and many close to him as Korean fascists whose rule fell just short of totalitarian, but not by much. The combination of dashed hopes post-liberation, repression, and other factors sparked violent opposition beginning in 1946 that would generate high levels of political violence, mutinies, and an outright insurgency. ${ }^{4}$ The fighting subsided only months before the country would meet an even greater test, the North Korean invasion of June 1950.

\section{Nation-Building Under Rhee and Beyond}

The ROK prevailed. U.S. assistance and help from other allies, including Japan, certainly helped, but the credit resides with the Koreans themselves and their leadership. Much of that success was military in nature: South Korea's armed forces and other security services suppressed the insurrections of 1946-1950 and evolved over the course of the war into a large and effective force capable of countering the nation's external threats. What is most striking about South Korea, at least when compared with other postcolonial states, is the extent to which Korean leaders (beginning with Rhee) brought to their tasks a keen sense of patriotism and national identity and a fully developed ideology that paired modernism and key aspects of contemporary development and modernization theory with indigenous strands of nationalism. They were, in short, serious nation-builders. This was obviously true with respect to their intense focus on economic devel-

3 Cumings, 1990, p. 234.

4 Cumings, 1990, pp. 237-290. 
opment, although, even in that case, as Cumings and Brazinsky have documented, Koreans refused to follow entirely the development script proffered them by U.S. and international institutions and instead elaborated a uniquely Korean approach intended to serve Korean interests and meet particular Korean requirements. Regardless, the results of their commitment to the economic aspects of nation-building are obvious today. The role of the country's astonishing economic success mimicked by the state's similarly intense attention paid to education and infrastructure must also not be overlooked.

Korean leaders, perhaps in part because of the initially precarious legitimacy of the South Korean state and the ever-present communist threat, also paid considerable attention to ideology. To a large extent, Koreans in 1945 were already in possession of strong national identities, but, as mentioned, there was little consensus about who should govern the new country and how it should be governed. There were also deep divisions between left and right that often were tied to fundamental economic issues. It did not help that the dispensation imposed by the United States (in coordination with the Soviet Union), which included the continuation of much of the Japanese colonial system, fell far from meeting Korean aspirations, either because it reinforced a certain socioeconomic balance or because it continued the country's dependence on and subordination to outsiders. For many, moreover, the North Korean case for being the legitimate Korean government was compelling.

Rhee and his allies crafted a positive nationalism that was more than a simple negative ideology (i.e., anticommunism) and that denied the communists a monopoly over Korean nationalism. Anticommunism was certainly an important feature, and it helped that the war left few illusions about what another communist invasion would mean for the south. It was not difficult for South Korean authorities to convince civilians of the need for a strong defense. For example, according to a South Korea history scholar interviewed for this report, South Koreans generally accepted military conscription as a patriotic duty.

Being anti something, however, is seldom enough to motivate people to fight or to foster legitimacy over the long term. Rhee and, subsequently Park Chung Hee (president, 1961-1979), shaped and 
mobilized Korean nationalism. ${ }^{5}$ They elaborated a particular vision of a modern Korea, one that could rival the communists' equivalent. It was grounded in the country's past, but it also was imbued with postwar, U.S.-inspired modernist ideas about economic, political, social, and technological progress. It helped that their development schemes succeeded, and they were able to bring real improvements to the Korean economy.

The Korean leadership's attention to ideology was, as Cumings argued, wholly consistent with Korean culture. North Korea, too, was able to tap into this ideology to reinforce regime legitimacy. ${ }^{6}$ This culture encouraged the cultivation of an organic identity built around family, people, and nation as well as efforts by leaders to impose that identity and stifle dissent. Under Rhee, Cumings writes, the result was less a Koreanized version of fascism than a "fascisitized version of Korean politics."7 Cumings uncharitably describes Rhee's doctrines in the following terms:

The ruling doctrines of the of the Rhee regime, in theory and practice, combined a pastiche of Korean Confucianism, Western fascism, democratic slogans, Chinese Nationalistic pretentiousness and haplessness, and effective Japanese method. The Confucian and Nationalist Chinese influence was palpable and something to be proud of: good traditional Koreans had always got their political models form China. The Japanese influence was never mentioned, but it was of central importance, given its entrenchment in bureaucratic practice. ${ }^{8}$

One representative example of Rhee's ideology was "The One People Principle," which stressed the unity of the Korean people with the Korean nation and called for the elimination of class distinctions, an end to factionalism, equality of men and women, and Korean

\footnotetext{
5 Telephone interview with Korean history scholar, March 20, 2015.

6 Cumings, 1990, p. 191.

7 Cumings, 1990, p. 193.

8 Cumings, 1990, p. 209.
} 
national unity. In Cumings's words, the nation "ought to be an organic whole, a body politic akin to the corporeal man."9 According to Cumings, Rhee's ideologues broadened the metaphor to include the family. "A nation is an enlarged home and its people are an extended family ... the people must live together in the spirit of one family." 10 It was, as Cumings put it, "ersatz Confucianism" that was remarkably similar to Kim Il Sung's Juche ideology or the ideas of the Reverend Sun Myung Moon and equally well suited for a Korean audience.

Rhee's allies reinforced his doctrines, elaborated them, and promoted them through their own networks and instruments, including the press. At the top were ideologues such as An Ho-Sang, an author and educator who became Korea's first minister of education. An expanded version of Rhee's "One People" doctrines along nationalist lines was done in such a way that they explicitly endorsed not just the republic but the personal rule of Rhee as well. ${ }^{11} \mathrm{His}$ policies as minister, moreover, were "designed to achieve totalitarian control of what he thought was the best venue for inculcating his ideas, the South Korean school system." 12 Beginning in 1948, there was a purge of "heterodox" teachers, who implemented methods for policing the ideologies of teachers and students and maintained the highly centralized Japanese school administration (which gave the state top-down control over community schools and everything from teacher appointments to the content of textbooks). They also maintained the militaristic aspects of Imperial Japanese schools, including the wearing of Japanese-style black military uniforms, shaved heads, and early-morning mass formation drills. "Even into the 1970s, South Korean schools were little museums of the colonial era in form, if not necessarily in content . . . often by the same teachers who had taught in the colonial system." ${ }^{13}$ Correct ideology was "drummed into the students' heads on a daily basis by rote recitation

\footnotetext{
9 Cumings, 1990, p. 210.

10 Cumings, 1990, p. 210.

11 Cumings, 1990, p. 211.

12 Cumings, 1990, p. 212.

13 Cumings, 1990, p. 210.
} 
and memorization, by periodic drilling and marching, and by frequent political campaigns that festooned schools everywhere with banners and slogans."14

The regime also made heavy use of student and youth groups; this served two functions: indoctrinating Korean youth and providing instruments of intimidation and violence. All-male secondary students were automatically enrolled in An's Student National Defense Corps, which examined students for their ideological correctness and involved them in military training as well as had them participate in government-sponsored political demonstrations. All other student organizations were outlawed. ${ }^{15}$ South Korea in fact saw a proliferation of rightwing regime-sponsored youth groups that helped indoctrinate youth while furnishing the regime and its allies with shock troops for street battles and terrorism. They enabled the Korean right to "fight fire with fire" against leftist groups. ${ }^{16}$ They also provided recruits for the constabulary and the ROKA.

A regime-sponsored labor movement was another tool that successfully pushed aside the largest leftist labor union that organized Korean labor between liberation and 1947. ${ }^{17}$ The pro-regime union had help from the police, and together they were able to quash the leftist union through violence and arrests. ${ }^{18}$ Cumings describes one incident in which pro-regime strikebreakers beat workers with clubs labeled "correct one's mental attitude." 19 The government continued to dominate the labor movement in subsequent decades. In 1961, for example, the Korean Central Intelligence Agency, according to Cumings, reorganized labor, appointing a committee that created 12 unions, and founded a new national labor federation, the representatives of which "all pledged fealty" to the Park regime's economic and politi-

\footnotetext{
14 Cumings, 1990, pp. 214-216.

15 Cumings, 1990, pp. 212-213.

16 Cumings, 1990, p. 193.

17 Cumings, 1990, p. 203.

18 Cumings, 1990, pp. 204-205.

19 Cumings, 1990, p. 204.
} 
cal program. ${ }^{20}$ Rhee and Korea's subsequent rulers also benefited from the large and efficient state bureaucracy that was a legacy of the Japanese occupation. It functioned, Cumings writes, "to give coordinated, coherent penetrative effective structure, a powerful backbone, to the frequently incontinent Rhee regime."21

\section{U.S. Attention to Korean Nationalism and Indoctrination}

The U.S. government worked closely with the ROK to advance its nation-building efforts, including giving attention to indoctrination and ideology. Fully aware of Rhee's excesses and those of his successors, the United States tried to shape Korean policies as much as possible so that they would evolve in a manner compatible with U.S. interests and contemporary American ideas about nation-building and political modernity. U.S. advisors, for example, encouraged the Koreans to focus on economic development while trying to influence the Koreans to adopt policies more consistent with American-style economic liberalism rather than the Koreans' statist and arguably mercantilist approaches. The U.S. advisors even tried to encourage the development of a more independent yet still anticommunist labor movement akin to those in the United States. For example, according to Cumings, the U.S. Information Agency, which had a lead role in attempts to engage with Koreans and shape their ideals and values, presented movies about "the role of labor unions in free society." 22

The United States, led by the U.S. Information Agency, also conducted extensive outreach efforts to Korean intellectuals and youth groups in an effort to inject liberal and modernist ideas into contemporary currents in Korean nationalist thinking. Brazinsky credits U.S. outreach to Korean academics and intellectuals over the course of the 1970s with encouraging the development of a group of intellectuals willing to fight against military dictatorship and push the country

\footnotetext{
20 Bruce Cumings, Korea's Place in the Sun, New York: W. W. Norton, 2005, p. 372.

21 Cumings, 1990, p. 214.

22 Cumings, 1990, p. 205.
} 
toward greater democracy. ${ }^{23}$ Regarding youth groups, U.S. officials worked to create and grow a variety of movements intended to promote patriotism and values seen as correlating with liberal democracy and economic liberalism and capitalism. Among these movements was the 4-H Club, which the United States introduced into Korea in 1964 to reach rural youth. ${ }^{24}$ The point, Brazinsky argues, was both to disseminate agricultural and basic economic skills while cultivating particular forms of patriotism and ideas supportive of the Korean government and its modernist agenda, if not its autocratic tendencies. ${ }^{25}$

\section{The Republic of Korea Army}

The ROKA, of course, was another nation-building tool. It traces its origins to the decision by American occupation authorities in 1946 to stand up a Constabulary under the supervision of Provisional Korean Military Assistance Group (PKMAG). The purpose was to minimize the direct role the United States had in policing the country and countering political unrest. In 1948, with the birth of the ROK, the constabulary changed its name to ROKA, and PKMAG gave way to the U.S. Military Advisory Group to the ROK (KMAG).

One of the policies PKMAG/KMAG adopted that arguably only exacerbated the fledgling government's legitimacy deficit was its near complete reliance on veterans of the Japanese military. Indeed, virtually all the officers in the Constabulary and ROKA were veterans of either the Japanese army or the Japanese proxy force in Manchuria, the

23 Gregg Brazinsky, Nation Building in South Korea: Koreans, Americans, and the Making of a Democracy, Chapel Hill: University of North Carolina Press, 2007, p. 188.

24 Brazinsky, 2007, p. 212.

25 Brazinsky also notes the important role of American church groups, many of which had been active in Korea since the turn of the 20th century. In addition to promoting Christianity, they linked the religion to a particular nationalist, anticommunist, and pro-regime ideology. Given the power of Christian churches in Korea today, the importance of this messaging cannot be discounted. 
Manchukuo army. ${ }^{26}$ Many in fact had graduated from Japanese military academies and schools. Another problem was that, in their rush to expand the force as quickly as possible, the Koreans and PKMAG/ KMAG did little vetting, opening the ranks to members of the thuggish far-right associations as well as leftist and other dissidents of all stripes who sought refuge. ${ }^{27}$ Some would support the rebellions of 1948 by mutinying and attacking government institutions. In 1949, two ROKA battalions crossed the 38th parallel and attempted to defect. ${ }^{28}$ At the same time, other Constabulary or ROKA units fought to suppress the rebellions, often with brutal methods, including meting out collective punishment against communities suspected of supporting rebels or simply turning a blind eye while extremist paramilitary groups did the dirty work. ${ }^{29}$ Korea's military leadership ended up having to work hard to purge the fledgling force of unwanted-above all leftist-elements.

By 1950, ROKA - thanks in part to U.S. SFA efforts-had become a fairly proficient antiguerilla force, although it was woefully unequal to the challenge of fending off the more heavily armed North Korean army that invaded in June of that year. ROKA was, for example, a fairly light force. It had no tanks, weak artillery, and little ability to stop the Russian-built armor used by the North Koreans. ${ }^{30}$ ROKA commander Sun Yup Paik, for example, described how, in the first days of the war, his men's antitank rounds failed to stop advancing tanks, so his men had to resort to "suicide squad" tactics involving climbing atop the tanks with hand grenades and TNT until they learned to mass fire

26 Bryan Robert Gibby, Fighting in a Korean War: The American Advisory Missions from 1946-1953, doctoral thesis, Columbus: Ohio State University, 2004, p. 32. According to Gibby, all but two of the first 110 officers in the Constabulary hailed from the Japanese Army or the Manchukuo Army (p. 32).

27 Gibby, 2004, p. 37.

28 Gibby, 2004, p. 97.

29 Gibby, 2004, pp. 58-60.

30 Sun Yup Paik, From Pusan to Panmunjon, Washington, D.C.: Potomac Books, 2007, p. 10. Paik noted that ROKA units had only a few howitzers in their position, and they were smaller in caliber and had a shorter range than the North Koreans' guns (i.e., among other things, ROKA was the loser in artillery duels). 
on individual tanks. ${ }^{31}$ Indeed, the first year of the Korean War was a traumatic experience for the ROKA. During the first week, the communists shattered many ROKA units, and the survivors fled south. Entire ROKA divisions disintegrated, and the South Korean government had to resort to press gangs to force people to serve. ${ }^{32}$

The United States quickly introduced ground forces from Japan (and later Hawaii and the continental United States) to stem the communist tide. Eventually, the U.S. and South Korean forces fought the North Koreans to a halt at the Pusan Perimeter in the southeast corner of the ROK and, aided by additional forces under the United Nations (UN) mandate and the amphibious landing at Inchon in September 1950, drove the communist forces back into North Korea. Combined UN forces, including several ROKA divisions, advanced deep into North Korea until they were struck in late November 1950 by a massive Chinese offensive. During the Chinese attack, several ROKA regiments and divisions (which now included far greater numbers of U.S. Army KMAG advisors) were virtually wiped out.

From its nadir in 1951, however, ROKA went on to achieve success after success. In 1953, ROKA counted 18 divisions and a total of 600,000 men. More important, ROKA quality improved, despite the ongoing combat. As early as the Chinese offensive of October 1952, the U.S. command noted that the ROKA 9th Division stood its ground in the face of a massive Chinese attack, suffering some 3,500 casualties in a ten-day period. ${ }^{33}$ By the end of the Korean War in July 1953, the ROKA manned a considerable portion of the front line. The South Korean government, moreover, no longer had to resort to press gangs, and mass conscription appeared to go smoothly from then on. ${ }^{34}$ The ROKA had earned the respect of its American advisors as well as other foreign observers. Brazinsky cites a British military attaché who

\footnotetext{
31 Paik, 2007, pp. 10-13.

32 Email from Korean history scholar, May 12, 2015.

33 Robert D. Ramsey, III, Advising Indigenous Forces: American Advisors in Korea, Vietnam, and El Salvador, Global War on Terrorism Occasional Paper, Fort Leavenworth, Kan.: Combat Studies Institute Press, U.S. Army Combined Arms Center, 2006, p. 9.

${ }^{34}$ Email from Korean history scholar, May 12, 2015.
} 
noted in 1975, "considering the short time the ROK army has been in existence and the comparative youth of the senior officers . . . a surprisingly high standard of military efficiency has been reached." The attaché added that ROKA officers were "patriotic and loyal" and that morale was "basically good." 35

\section{The ROKA Goes to Vietnam}

Proof of the ROKA's fighting form came a little more than a decade after the war, when ROKA deployed to Vietnam, where it won the admiration of friends and foes alike. South Korean military involvement in Vietnam started in September 1964, when the ROKAs 1st Mobile Army Surgical Hospital arrived in South Vietnam. In February 1965, the leading elements of the ROK Military Assistance GroupVietnam (ROK-MAG-V), a 2,400-person training and advisory organization, started to arrive in South Vietnam. Of far greater importance was the September 1965 arrival of South Korean combat units. President Park, himself a former ROKA general, was personally involved in the selection of the units that would deploy to Vietnam. Two ROKA divisions, the Capital (Tiger) and 9th (White Horse), which had impressive records during the Korean War, were selected to form the core of the South Korean military presence in Vietnam. Importantly, before these units were deployed to Vietnam, many personnel were replaced with high-quality volunteers, with considerable emphasis on officers who could speak English, thus maximizing their units' ability to operate alongside U.S. forces. Enlisted men were encouraged to volunteer for service in Vietnam and were told that each year of service in Vietnam would count as three years of total military service. Additionally, if they wanted to have a career in the ROKA, service in Vietnam would be of considerable benefit and importance. ${ }^{36}$

The Capital Division and the ROK Marines' 2nd ("Blue Dragon") Brigade arrived in South Vietnam by the end of 1965. The White Horse division joined them in 1966. By the end of that year, ROK troop totals

\footnotetext{
35 Brazinsky, 2007, p. 97.

36 Stanley Robert Larsen and James Lawton Collins Jr., Allied Participation in Vietnam, Washington D.C.: Department of the Army, 1975, pp. 141-143.
} 
(including the marines) in Vietnam approached 50,000. South Korean units were primarily deployed in the central portion of South Vietnam. They quickly developed a formidable combat reputation.

The ROK units in Vietnam specialized in small-unit (i.e., battalion down to platoon) operations against both the irregular Vietcong as well as the regular North Vietnamese army units in that portion of the country. In that regard, ROKA lower echelon leadership proved to be excellent—a necessity when conducting dispersed, small-unit operations. It is estimated that the ROK forces in Vietnam achieved a high casualty ratio against the communists, up to 24-to-1 in some engagements. ${ }^{37}$ By the time of the so-called Tet Offensive in 1968, it was clear that communist units were attempting to minimize their contact with South Korean forces in Vietnam. U.S. officers who interacted with ROK forces were very impressed with their professionalism, morale, enthusiasm, and discipline. One criticism some U.S. Army officers had of the ROKA in Vietnam was the South Koreans' tendency to want to conduct very extensive, perhaps overly extensive, lengthy planning before conducting an operation. Prior to departing from Vietnam, the senior U.S. Army officer, GEN William Westmoreland, remarked that the reports were "continually received on the courage and effectiveness of ROK forces in South Vietnam." ${ }^{38}$ ROK forces received consistent praise by junior- and mid-grade U.S. military personnel in Vietnam who had the opportunity to work with the Koreans.

ROK ground forces remained in combat in Vietnam longer than their U.S. counterparts. For example, by the time of the so-called Easter Offensive in March-April 1972, few U.S. ground combat units remained in South Vietnam. Considerable ROK units, however, still were in position in the central portion of the country. Those ROKA units defeated every North Vietnamese effort to take their positions. When the Paris Peace Talks concluded in early 1973, the ROKA still had ground combat units in South Vietnam, long after all U.S. Army forces departed.

\footnotetext{
37 Larsen and Collins Jr., 1975, pp. 147-148.

38 Larsen and Collins Jr., 1975, p. 147.
} 
The peak number of South Korean troops in Vietnam was roughly 50,000 personnel. Eventually, more than 300,000 South Koreans served in Vietnam. Of that number, roughly 5,000 men were killed in action or died of wounds. ${ }^{39}$ Never defeated by the communists in any significant engagement in Vietnam, the ROK army had shown that it had come a long way from 1946-1951, when it was riven by political strife and badly beaten by communist forces.

\section{KMAG and ROKA}

With respect to the Constabulary and ROKA, the United States demonstrated significant concern for officers' professional development, including their patriotism and sense of loyalty to the state. The focus, of course, was on basic soldiering and the skills associated with leading and planning operations, but the U.S. advisory mission consistently aimed higher. This was particularly true after the front stabilized in 1951, and the United States took advantage of the relative calm to initiate a major overhaul of ROKA while growing it. ${ }^{40}$ Notably, the United States pushed back against Rhee's desire to grow the force as rapidly as possible and agreed to expand ROKA only as quickly as it could both sustain the force and ensure its overall quality. ${ }^{41}$

U.S. advisors did not think in terms of political indoctrination but rather professionalism and leadership training. Both GEN Matthew Ridgeway and GEN James Van Fleet thought a major weakness of ROKA was its leadership development, which they believed needed to come before growing the army. Ridgeway, according to Gibby, wanted officers to posses a "will to fight," and he thought that, to do that, they had to be instilled with patriotism, honor, integrity, devotion to duty, and professional pride. ${ }^{42}$ Critical of the Koreans' battlefield

39 Edward Marek, "ROK Army and Marines Prove to Be Rock-Solid Fighters and Allies in Vietnam War," talkingproud.us, undated.

40 Gibby, 2004, pp. 186-187.

41 Gibby, 2004, pp. 225-228.

42 See also Major Robert K. Sawyer, Military Advisors in Korea: KMAG in Peace and War, Kindle ed., Walter G. Hermes, ed., Army Historical Series, Washington, D.C.: U.S. Army, Center of Military History, 1988. Location 2791. 
performance, he thought that, without these values, they would continue to perform poorly regardless of how much firepower and equipment the United States provided. ${ }^{43}$ Van Fleet was similarly concerned with giving Koreans "the will to win" and believed that the key to this goal was to be found in improved officer and unit training. ${ }^{44}$

The United States invested heavily in education and training, sponsoring numerous academies and branch service schools, as well as bringing Korea's best to the United States for further training. In all of the U.S. training programs, KMAG's objective went beyond providing technical training. Rather, the American military hoped to reshape the Koreans' character, to instill in them an appropriate sense of duty, and "bolster officers' commitment to either the South Korean state or the global struggle against Communism." Even during the days of the pre-ROKA Constabulary, U.S. advisors insisted on including in their initial training efforts classes on Korean history and encouraged "activities that would promote national unity." ${ }^{5}$ Brazinsky cites one of the first instructors at the Constabulary's Officer Candidate School as recalling teaching his students the Korean national anthem for the first time. ${ }^{46}$

At the top of the U.S.-sponsored Korean military school network was the Korean Military Academy (KMA), which was modeled after U.S. Military Academy at West Point. According to Brazinsky, the KMA's official mission was to "develop physical, mental and moral character in the young cadet and to cultivate unselfishness and loyalty to country." 47 From the time they entered the KMA, Brazinsky writes, cadets were exposed to the formal symbols and slogans that it adopted. The school flag, consisting of a yin-yang symbol against a background of a hibiscus flower and a laurel tree, "was intended to elicit loyalty

\footnotetext{
43 Gibby, 2004, p. 228.

44 Gibby, 2004, p. 185.

45 Brazinsky, 2007, p. 74.

46 Brazinsky, 2007, p. 74.

47 Brazinsky, 2007, p. 86-87.
} 
from cadets to both army and country." 48 While the school offered courses on military subjects, it also provided a broad liberal arts curriculum and courses on the Korean language and Korean history, all of which was intended to reinforce cadets' "sense of belonging to a single national people with a common culture, history, and language," 49 while also broadening cadets' perspectives by giving them a deeper understanding of national security and international affairs. According to Brazinsky, KMA's U.S. advisors even tailored extracurricular activities to shape the outlook of aspiring officers. Cadets participated in a wide array of ceremonies, parades, and associations. For example, on National Army Day, they paraded through a stadium in Seoul with representatives from the rest of the army and the other branches of the military. The first time the ceremony was held in 1956, Rhee gave a speech emphasizing the responsibility of the South Korean military to the nation as well as to the free world.

KMAG-sponsored military education also aimed to do two related things: to inculcate among Korean officers self-confidence and belief in their capacity to solve problems and to promote a similarly optimistic view of Korea's future. The idea was to impress on them a particular modernist vision of Korea as a developed and successful nation and match that vision with a belief in the Korean people's capacity to bring that future to bear-with the military in the lead. Thus, KMAG hoped that Koreans who studied at U.S. military schools would be enchanted by American modernity and want it for their country. There and throughout the U.S.-sponsored training establishments in Korea, as well as throughout the ROKA, wherever U.S. advisors interacted with Korean advisees, the U.S. objective was to encourage Koreans' confidence and their enthusiasm for building their country and to instill in Korean officers a keen sense of duty and patriotism.

Brazinsky insists that the military education system and the experience in general of working closely with embedded U.S. advisors had a "transformative effect on ROK officers." The United States successfully instilled within the ROKA a belief in the country's future, which went

\footnotetext{
48 Brazinsky, 2007, p. 87.

49 Brazinsky, 2007, p. 87.
} 
hand in hand with loyalty to the regime and the idea that the military had a critical role to play. Of course, as Brazinsky notes, ROKA officers went farther than U.S. advisors intended by coming to believe that they, as the vanguard of Korean progress, should lead their country in the political sense as well. The Koreans also never warmed up to the United States as much as U.S. planners hoped: Korean nationalism was incompatible with foreign domination, and Koreans did not regard all of what the United States had to offer in terms of politics and values as equally worthy of adoption. Koreans selected what they wanted. Fortunately, Korea's U.S. mentors tolerated the Koreans' choices, thereby avoiding any real confrontations. Moreover, the Koreans, however much they wished to keep the United States at arms' length, never came to regard the United States as intending to retain its hegemony over the country. They also believed that they shared with the U.S. advisors the objective of making Korea strong and independent. Crucially, the Americans did not give them cause to change their mind.

This last point is worth emphasizing: ROKA in effect began life as a colonial force-an auxiliary to the U.S. occupation-led almost entirely by Japanese-trained officers. The ROK itself was a U.S. creation, one that relied on state institutions that were a legacy of Japan. Yet, the South Korean state and army successfully escaped the association with colonialism and avoided being regarded as instruments of a new colonial master (the United States). They managed this in part by demonstrating in myriad ways their independence from U.S. control, and the United States knew to act in ways that tended to satisfy the Koreans' concern for autonomy. The Koreans also successfully anchored their state and army in a collective, national identity that withstood competition from Korean communists. As we discuss in the next chapter, the army of South Vietnam, which was a French colonial creation, never really escaped the association, and the Vietnamese communist argument that the South Vietnamese had simply exchanged their French colonial masters for U.S. ones ultimately rang true for many. 


\section{U.S. Attention to Civilian-Military Relations}

In addition to KMAG's concern for the ROKA's character and patriotism, after the war, the United States wanted to enhance the ROKA's prestige in the Korean public eye and also use the military to support economic development, thus enhancing the idea of the military as a primary agent of modernization. According to Brazinsky, KMAG dispatched ROKA forces on "civic action" missions "as a means of benefiting the Korean economy and of creating a positive and friendly image of ROK [forces]."50 These, Brazinsky writes, worked with ROKA engineers to rebuild bridges and roads that had been destroyed. KMAG also supplied asphalt-laying equipment with the expectation that the Koreans would then initiate their own road-building projects. KMAG sometimes identified projects, but with full ROK cooperation. The scope of the projects expanded throughout the Rhee years and included large irrigation and land-reclamation efforts. Thousands of Korean officers and enlisted men took part.

According to Brazinsky, KMAG hoped to "channel the nationalistic energies of South Korean officers toward the task of economic reconstruction." One result, he argues, was that KMAG indirectly strengthened the military elite's confidence in their ability to lead the country. Unfortunately, the military's views eroded officers' commitment to the belief "long preached" by the United States that the army needed to remain aloof of politics.

\section{Korea's Mixed Record}

Korea's record is ambivalent, especially if one looks beyond the ROKA's success as an effective fighting force and the ROK's emergence as an economic giant and, recently, a stable democracy. The military's consistent meddling in politics through coups and outright military dictatorship (not to speak of a record of human-rights violations) makes clear that-at least by the standards of today's SFA, SSR, stability operations, and other guidelines-ROKA in many ways has not behaved

50 Brazinsky, 2007, p. 98. 
in a manner presumed to contribute to legitimacy. In the eyes of most Koreans, ROKA's bad habits, however, do not appear to have translated into diminished legitimacy either for itself or for the South Korean state. It is also hard to argue that Korean and American attention to political indoctrination (and Korean efforts to crush dissent) translated into loyalty to particular regimes. It appears that there is a difference between state and regime, with South Koreans often challenging the regime but not necessarily the republic itself. Koreans question who runs the republic and how it is run, but calls for ending the republic in favor of the obvious alternatives (North Korea or communism) appear limited to fringe groups. Political repression alone cannot explain the legitimacy of the ROK-which, one should recall, was technically a U.S. invention. 



\section{The Army of the Republic of Vietnam}

The ARVN was created by a fledgling state facing grave internal and external security threats, with substantial assistance from the United States. In its roughly 20-year existence, the ARVN grew to an enormous size yet struggled to become an effective force. Among the reasons for the failure of the ARVN and the republic it served were the limitations of Saigon's nation-building effort, particularly under Ngo Dinh Diem (whose record was much stronger than his successors), and the Vietnamese leadership's failure to develop the ARVN in such a way that it complemented a larger political project. For their part, U.S. military strategists and civilian policymakers involved in the creation and evolution of the ARVN similarly made decisions that, while reasonable at the time, may have made matters worse or at least diminished the importance of serious problems in their estimations of how well the war was going.

It must be acknowledged that attempting to deduce lessons from the Vietnam War is a treacherous activity, given the sheer number of factors at play and the divergent opinions among scholars regarding why North Vietnam won and what, if anything, the United States might have been able to do about it. One of the more fundamental disputes is that between what might be called the COIN camp (associated with Andrew Krepinovich and John A. Nagl) and the so-called Clausewitzian camp (associated with Harry G. Summers). ${ }^{1}$ The former argue

1 For a discussion of this debate, see Dale Andrade, "Westmoreland Was Right: Learning the Wrong Lessons from the Vietnam War," Small Wars and Insurgencies, Vol. 19, No. 2, June 2008. 
that the United States erred in its preoccupation with the conventional threat and its insistence on fielding a conventional force that operated as such while building the ARVN into its mirror image. Had South Vietnam and the U.S. military waged a proper COIN campaign, the argument goes, the war might have turned out better. The latter more or less argue the opposite: The United States failed to recognize the importance of the conventional threat represented by North Vietnam and essentially defeated itself by being unwilling to target that nation directly. North Vietnam represented what Clausewitz famously described as a war's Schwerpunkt (center of gravity). The U.S. focus on the conventional war, per the argument, was the correct response to the threat represented by communist "main force" troops against which small and light COIN-oriented units would have been utterly ineffectual. ${ }^{2}$ Thus, as Andrade put it, "Westmoreland was right." 3 If anything, the problem was not enough conventional power or conventional power aimed at the wrong targets.

Similarly, many point to the fact that South Vietnam's demise ultimately came from a conventional invasion, meaning that whatever gains the United States or Saigon might have been making with respect to Vietnam's guerilla war had no real meaning. ${ }^{4}$ For example, Merle Pribbenow has argued-drawing on North Vietnamese sources-that the final offensive in 1975 worked not because of its scale or even necessarily the inadequacies of the ARVN (which, he notes, was "no paper tiger") but rather because of a cunning strategy marked by deception. ${ }^{5}$

2 Merle Pribbenow, "Vietnam's Forgotten Army: Heroism and Betrayal in the ARVN," review, Journal of Military History, Vol. 72, No. 4, October 2008.

3 Andrade, 2008.

4 According to Lien-Hang T. Nguyen, an author of one of the few major histories of the Vietnam War that draws primarily on northern Vietnamese sources, "the key to Hanoi's ultimate success in the war lay not in launching general offensives or even winning hearts and minds in South Vietnam; rather, it resided with its world relations campaign aimed at procuring the support of antiwar movements around the world" (Lien-Hang T. Nguyen, Hanoi's War: An International History for the War for Peace in Vietnam, Kindle ed., Chapel Hill: University of North Carolina, 2012).

5 Merle L. Pribbenow, "North Vietnam's Final Offensive: Strategic Endgame Nonpareil," Parameters, Vol. 29, No. 4, Winter 1999-2000. 
Although Pribbenow does not address the issue, the implication is that the guerilla war was naught but a sideshow. The fight was not about hearts and minds but battalions well placed and well used. The NVA played its hand brilliantly in 1975 and thus won.

Our approach represents something of a compromise. On the one hand, the Clausewitzians are correct in that a COIN-focused campaign would have been inadequate to counter the real and dire threat posed by "main force" units and the NVA. That said, the insurgency, too, was real and not something Saigon or the United States could ignore. Also, main force units consistently acted with irregular units. Tet, for example, was a joint NVA-Vietcong operation, with the two forces throwing their weight into the fight and making it possible for the communists to strike as hard as they did and in as many places as they did at the same time. ${ }^{6}$ NVA units, moreover, benefited from local support to infiltrate South Vietnam and operate there, meaning that main force units in the south were unlikely to have been as effective as they were without the parallel existence of the guerrilla war. This was true even at the very end, when the NVA made the conventional assaults on South Vietnamese defenses that so impressed Pribbenow: Their ability to infiltrate South Vietnam without detection required the complicity of a lot of South Vietnamese civilians. In other words, part of what made the conventional offensive so effective was the support of at least a significant portion of local populations, which had to have been cultivated over time. ${ }^{7}$

In addition, the COIN aficionados were correct to point to the intrinsically political nature of the conflict. It can even be described as a revolutionary war. Much depends, however, on what is meant by "political" or "revolutionary." Summers famously rejected the idea of a revolutionary war and opined "we were caught up in this business of counter-insurgency, winning hearts and minds, the whole business of a social revolution rather than a war." ${ }^{3}$ However, as George R. Vickers

\footnotetext{
6 Nguyen, 2012.

7 Pribbenow, 1999, pp. 68-69.

8 U.C. Berkeley Institute of International Studies, "Conversation with Colonel Harry G. Summers, Jr.," in Harry Kreisler and Thomas G. Barnes, eds., Conversations with History,
} 
has noted, Summers and others tended to equate revolutionary with insurgency and think of it in terms of the Maoist conception of the phases of revolutionary war. ${ }^{9}$ This view was, to cite Vickers, "misleading" given the communists' own conception of the war. ${ }^{10}$ To them, he argues, citing General Vo Nguyen Giap, the conflict was revolutionary not because it involved an insurgency but because it was a "people's war" involving the mobilization of the nation and the unification of different elements of society around a broad struggle that had not just a military component but a domestic one (i.e., reform and nation-building). ${ }^{11}$ The war required a degree of unity of effort that would not have been possible at least on the North Vietnamese side were Hanoi not able to consolidate its power and legitimacy and promote its ideology among the people such that they would accept sacrifices (e.g., mass conscription and high casualty rates) and hold up, notwithstanding acute deprivation and U.S. firepower. As for the Republic of Vietnam, which one South Vietnamese writer described as a "bastard child of French colonialism and American anti-Communism," it needed quickly to generate legitimacy and establish itself as the legitimate claimant to Vietnamese national identity in the face of opposition from many quarters (including but not exclusively communist), many of which had compelling rival narratives of the nation and arguments for alternative sources of legitimacy. ${ }^{12}$ To some extent, while victory or defeat depended on the outcomes of conventional clashes (and we can read the ARVN's defeat in terms of the relative strengths and weaknesses of the opposing forces and conclude that one side simply outfought the other), it would be wrong to isolate the two forces from the

March 6, 1996.

9 George R. Vickers, "U.S. Military Strategy and the Vietnam War," in Jayne S. Werner and Luu Doan Huynh, eds., The Vietnam War, Vietnamese and American Perspectives, Armonk, N.Y.: M. E. Sharpe, 1993, pp. 126-127.

10 Vickers, 1993, p. 127.

11 Vickers, 1993, p. 127.

12 Gregory A. Daddis, Westmoreland's War: Reassessing American Strategy in Vietnam, Oxford: Oxford University Press, 2014, p. 161. Daddis cites the South Vietnamese writer Ngo Quynh. 
larger political context and the many factors that, to varying degrees, enabled the two sides to stay in such a costly fight for so long. Better strategy and leadership might have won out in 1975, but many factors contributed to getting both sides to where they were that spring.

This is not to say that the United States should have focused on protecting the population or trying to separate civilians from insurgents per COIN doctrine, but rather that it should have been more attentive to the larger political aspects of the conflict. How well was Saigon's revolution going? It may have been the case that there was little the United States could have done about Saigon's nation-building efforts or lack thereof. The mistake may ultimately have been in insisting that what the United States was doing-namely building a huge army-would matter notwithstanding Saigon's failure to establish its legitimacy or implement a coherent program that might have accomplished that. Indeed, the benefit of being more attentive to nationbuilding and the ARVN's place in it might simply have been making more accurate assessments of the progress of the war and the prospects for victory.

\section{The Birth of South Vietnam}

Following their disastrous defeat at Dien Bien Phu in May 1954, the French elected to withdraw from their colony in Indochina. The 1954 Geneva Accords resulted in the division of Vietnam into the communist north (the Democratic Republic of Vietnam) and the ostensibly democratic south (the Republic of Vietnam). The French, apparently eager to quit their entanglement, more or less left to a variety of Vietnamese actors responsibility for creating from the colonial administration and security forces a new united country from what was during the colonial regime different provincial governments.

In the best of circumstances, a viable Republic of Vietnam would have been difficult to construct. Vietnamese national identity has always been strong, but Vietnam was ethnically and religiously diverse, divided by geography and regional differences sharpened by regional variations in French approaches to administration and the degree of 
French influence. Such nonstate actors as religious sects and criminal syndicates weakened Vietnam politically by contesting the nascent government's political legitimacy. Association not just with the French but also with the Japanese occupation, moreover, tainted Vietnam's government and security forces. Well-trained and educated Vietnamese cadres capable of leading the military and the civilian administration were rare because of France's practice of reserving positions with real decisionmaking responsibilities for Frenchmen. Another crucial sticking point was that Vietnam's communists had led the struggle against France and largely prevailed in shaping dominant narratives regarding what it meant to be Vietnamese and which government was the appropriate choice for patriots. In addition, some argue that Vietnamese culture includes the Chinese Confucian concept of "The Mandate of Heaven," the notion that legitimacy is conferred to a leader or state by heaven. ${ }^{13}$ Vietnam's communists claimed the mandate on the basis of the fact that, in 1945, the last Vietnamese emperor, Bao Dai, gave the ceremonial seal and sword to representatives of Ho Chi Minh. ${ }^{14}$ Thus, the Democratic Republic of Vietnam (North Vietnam) had a far easier time convincing people of its legitimacy than did the anticommunist southern republic.

This was not to say that the Vietnamese universally supported the communists and categorically denied support to the south's new government. However, to rally support, it was incumbent on the southern leadership to capitalize on the support it had as well as the anticommunist sentiment shared by many and promote a narrative of the nation that rivaled the communists'. The south, to cite Rufus Phillips's trenchant memoir of the war, had to "develop a political cause as compelling as that of the communists." 15 That required cultivating South Viet-

\footnotetext{
13 Brian Michael Jenkins, Why the North Vietnamese Keep Fighting, Santa Monica, Calif.: RAND Corporation, D-20153-ARPA/AGILE, 1970a, p. 1. For a discussion of the "Mandate in Heaven" idea as applied to Vietnam, see Robert K. Brigham, "Ho Chi Minh, Confucianism, and Marxism," in The War that Never Ends: New Perspectives on the Vietnam War, Lexington, Kentucky: University Press of Kentucky, 2007, pp. 105-120.

14 Jenkins, 1970a.

15 Jenkins, 1970a, p. 2.
} 
namese nationalism — and establishing the new regime's independence from the United States, lest the United States be perceived as France's replacement, and the new republic a colonial puppet. South Vietnam also had to build an army that could help the country meet its growing security requirements, ideally one that supported and complemented the larger nation-building project.

Finally, time was of the essence: The Geneva Accords stipulated that national elections would be held on Vietnam's future, and all involved understood that the northern communists almost certainly would win. ${ }^{16}$ Ho Chi Minh, according to one account, was so confident that he could achieve the unification of the country through elections that his government made relatively little attempt to interfere in the south, resulting in a lull in fighting that lasted for a few years and providing southern leaders with a brief pause in which they enjoyed a relative free hand to resolve issues. ${ }^{17}$ Another motive for a pause can be found in Lien-Hang T. Nguyen's recent Hanoi's War. According to Nguyen, in the years following independence, communist party leaders in Hanoi hesitated while debating the relative merits of a "north first" strategy that prioritized nation-building in the north or a "south first" strategy that involved prioritizing military efforts in the south in the hope that the fighting would enable the party to mobilize the masses. ${ }^{18}$ It is clear that, from the moment of independence in 1955, there was a race to "build a coherent something."19 South Vietnam's leaders, with support from France and the United States, hoped to buy time by putting off elections long enough for the southern government to get on its feet and weather an electoral showdown. ${ }^{20}$ By the next decade, the election clearly was off the table (elections in general were off the

\footnotetext{
16 Cumings, 1990, p. 214.

17 Robert Scigliano, South Vietnam: Nation Under Stress, Boston, Mass.: Houghton Mifflin Company, 1964, p. 17.
}

18 Nguyen, 2012.

19 Rufus Phillips, Why Vietnam Matters: An Eyewitness Account of Lessons Not Learned, Annapolis, Md.: Naval Institute Press, 2008, p. 305.

20 Philippe Devilliers, "The Struggle for the Unification of Vietnam," China Quarterly, No. 9, 1962, pp. 2-3. 
table, which did not help the government's efforts to build legitimacy), but the war escalated. Later, after the Tet Offensive in 1968 and the embrace in 1969 of Vietnamization, the race was on again, only now the goal was to ensure the country's viability following the looming U.S. withdrawal.

In 1955, the new government in Saigon, led by Ngo Dinh Diem, initiated what Diem referred to as a national "revolution" intended to reform Vietnamese society and the Vietnamese state and build the southern republic into a viable nation. ${ }^{21} \mathrm{~A}$ full analysis of Diem's nationbuilding project is outside the scope of this report, and it suffices to say that, in some ways, he did not go far enough, while in other ways he went too far. Indeed, Phillips portrays Diem as a flawed nation-builder who more or less understood the right path to take but was uneven with respect to implementation. Scigliano, for example, concluded that the Diem regime's efforts were "hardly revolutionary in the creation of a new governmental system and in infusing this system with a new spirit and with new leading personnel." ${ }^{22}$ Rather than mobilize many groups that should have been natural allies, such as his fellow anticommunist nationalists (which he feared), he neglected, suppressed, or alienated them. Among other things, Diem failed to effect positive changes that might have curried support among rural populations. The steps he did take-and above all the security measures intended to root out rural dissent - antagonized much of the rural population, pushing peasants toward the communists and giving new life to the rural insurgency, which took off in 1958-1959.23 At the most basic level, Diem failed to elaborate a Vietnamese nationalism that would have helped legitimize his government. According to Robert Brigham, Diem feared nationalism, which he could not control, and he intentionally avoided replicating what the North Vietnamese army was doing. ${ }^{24}$

\footnotetext{
21 Scigliano, 1964, p. 62.

22 Scigliano, 1964, p. 63.

23 Devilliers, 1962, pp. 13-15.

24 Telephone interview with Robert Brigham, March 23, 2015.
} 
It should be noted that North Vietnam was vigorously pursuing its own revolutionary agenda, which included sweeping land reform programs, economic or "socialist" development, efforts to consolidate power and state control, the creation and manipulation of various organizations and associations to extend control and promote the party line, and engagement with intellectuals and writers, who produced significant amounts of propaganda and propagandistic literature. Hanoi made mistakes. Its heavy-handed agrarian reform policies, for example, sparked rebellions. Hanoi, however, successfully suppressed armed dissent-in part by erecting an efficient police state-while at the same time working to rectify the mistakes and address grievances. ${ }^{25}$

Diem's missteps and other causes prompted some within the ARVN (with U.S. support) in 1963 to overthrow him, leading to a turbulent interregnum that lasted for several years, as various officers vied for political control. ${ }^{26}$ Eventually, General Nguyen Van Thieu rose to claim the presidency and was able to consolidate power, although factional rivalries divided the government and the military throughout his ten years in office. The contest between Thieu and his rival, Vietnam Air Force General Nguyễn Cao Kỳ, was particularly detrimental, as factions supporting the two sides within the civilian government and the military struggled for predominance.

Phillips, who is generous in his assessment of Diem, is not restrained with respect to the generals who succeed Diem, noting repeatedly their disinterest in many of the problems that Diem at least attempted to address. He also notes President Lyndon B. Johnson's policy amounted to picking whichever military officer seemed appropriate and backing him, while paying little attention to the need to cultivate the government's legitimacy through some degree of democracy and the need not to appear like Vietnam's colonial master. For example, according to Phillips, when Henry Cabot Lodge convinced Johnson to back a new Vietnamese junta leader, Nguyen Khanh, Johnson instructed Secretary

\footnotetext{
25 Nguyen, 2012.

${ }^{26}$ For more on Diem's downfall and the U.S. government's role therein, see Geoffrey Shaw's recent The Lost Mandate of Heaven: The American Betrayal of Ngo Dinh Diem, President of Vietnam, San Francisco, Calif.: Ignatius Press, 2015.
} 
of Defense Robert McNamara and GEN Maxwell Taylor to "make Khanh 'our boy"' and asked that there be photographs in the newspapers with McNamara and Taylor holding up Khanh's arms. ${ }^{27}$ That is exactly what McNamara and Taylor did during a visit with Khanh: There were photographs in the newspapers with McNamara holding up one arm, Khanh's hand in his, and Taylor holding the other. It was, according to Phillips, the "kiss of death," for it furnished the communists proof that Khanh was a U.S. puppet. Phillips cites a Vietcong leader as later claiming that "the greatest gift for us" was when $\mathrm{McNa}$ mara and Taylor toured with Khanh and had pictures taken with them holding up Khanh's hand and shouting "this is our man." "This," he reportedly said, "saved our propaganda cadres a great deal of effort." 28 Similarly, the United States greatly damaged the southern cause by pushing the ARVN aside when McNamara deployed conventional forces, which assumed primary responsibility for fighting. Whatever the significance of this particular episode, there is a consensus that notwithstanding Diem's failings, his American-backed and to some extent managed successors did much worse.

\section{Making the ARVN in the American Image}

Diem inherited a portion of the military forces that were previously under French control. As was the case with most of its colonies, France had raised large numbers of Vietnamese, Cambodian, and Laotian units starting in the late 19th century. During the 1945-1954 attempt to retain control of Indochina, French troops fought alongside and often led large numbers of locally raised units. By 1954, many of these Indochinese colonial units had been destroyed during the years of fighting against the communists, while others disbanded following the Geneva Accords. However, the government in Saigon did have a pool of French-trained veterans to draw on to build a new military, although few of the Vietnamese veterans had middle- or high-level command or

\footnotetext{
27 Phillips, 2008, p. 230.

28 Phillips, 2008, p. 230.
} 
staff experience, since the French usually reserved those positions for their own officers. It was at this point that the Americans started to take on a major role to develop the new military forces of the Republic of Vietnam.

There had been some U.S. involvement in Indochina while the French were still in control. Despite French efforts to have the Americans play a larger role in the fighting in Indochina, the administrations of President Harry S. Truman and President Dwight D. Eisenhower limited U.S. involvement to supplying some military equipment to French forces (including their colonial units) and a small training mission. The first U.S. Military Assistance Advisory Group (MAAG) in Vietnam was formed in 1950, but with a noncombat training role and fewer than 200 personnel.

Following the French withdrawal in 1954-1956, the U.S. role started to increase. In 1954, LTG John O’Daniel was dispatched to South Vietnam to provide a high-level advisor to the Saigon government. O'Daniel conducted an initial survey of the state of the Vietnamese National Army (VNA), which was the initial ground force of South Vietnam. The VNA included units and personnel that had fought with the French against the communists. Following his survey of the VNA, O'Daniel, who had access to President Diem, recommended a series of reforms and reorganizations that resulted in the ARVN being formed from the VNA in October 1955 and the national security structure of the South Vietnamese government being revised. ${ }^{29}$

The leadership of Vietnam's new military argued initially that South Vietnam was more likely to face an insurgency than an invasion and that the ARVN should be relatively light (nothing heavier than a $105 \mathrm{~mm}$ howitzer), mobile, and sustainable within the cultural and economic context of the country, meaning that it would rely on parttime conscripts and volunteers who would serve close to their communities. ${ }^{30} \mathrm{~A}$ veritable people's army, the ARVN would conduct local

29 “Letter from LTG John O’Daniel to President Diem," September 29, 1955, Carlisle, Pa.: Army Historical and Education Center, LTG O'Daniel Oral History Reports.

30 Robert K. Brigham, ARVN: Life and Death in the South Vietnamese Army, Wichita, Kan.: University of Nebraska Press, 2006, p. 5.; Scigliano, 1964, p. 13. 
antiguerilla and civil-action operations and be motivated by strong personal ties to fight to protect local communities. ${ }^{31}$ The ARVN would also create a series of special forces and counterguerilla groups in the Central Highlands to obstruct the invasion that MAAG feared.

MAAG rejected the Vietnamese proposal. According to one interpretation, O'Daniel imposed a conventional army on Vietnam for a number of reasons. One is that the preference reflected the army's Korean War experience, where that country was nearly overrun by a large ground offensive, and the United States sought to build the ARVN primarily for conventional combat, fearing that communist North Vietnam might launch a major attack similar to the 1950 attack on South Korea. MAAG's plan, in fact, was for the ARVN to block the expected invasion long enough for Pacific Command to mount an appropriate counterattack and perhaps another Inchon. When the U.S. Army started to build the ARVN, it did so in its own image. According to this U.S. paradigm, the ARVN needed to be big, and it needed to be focused on conventional combat operations. ${ }^{32}$ MAAG demanded, as Wiest put it, "to create a mirror of the American military in South Vietnam" and "construct an ARVN built on the primacy of conventional firepower and lavish logistical support." 33

Daddis offers a more qualified narrative. He asserts that O'Daniel and "all of O'Daniel's successors" recognized both conventional and guerilla threats and wanted to build an army that could handle both conventional warfare and COIN. ${ }^{34}$ However, because of the challenges of building a force that can do both, O'Daniel ended up pursuing a compromise that included building a large conventional army mirrored after the U.S. Army while creating lighter territorial forces that, with the paramilitary Civil Guard and Self-Defense Corps, would focus on COIN while freeing the ARVN to focus on fighting com-

\footnotetext{
31 Brigham, 2006, p. 5.

32 Devilliers, 1962, p. 2.

33 Andrew Wiest, Vietnam's Forgotten Army: Heroism and Betrayal in the ARVN, New York: New York University Press, 2007, pp. 22-23.

${ }^{34}$ Daddis, 2014, p. 149.
} 
munist main force units. ${ }^{35}$ Daddis insists that U.S. support for the territorial and other paramilitary forces as well as COIN-related training provided to the ARVN refute allegations that U.S. advisors were exclusively focused on the conventional threat. They were, moreover, sensitive throughout to criticism about their conventional focus. ${ }^{36}$ That said, it appears that, for a variety of reasons, building the ARVN and making it into a large conventional force that mirrored the U.S. Army became the main line of effort. Daddis asserts, for example, that the undermanned, ill-trained, and ill-equipped paramilitary forces until 1964 fell under the Interior Ministry rather than the Defense Ministry and consequently were outside MAAG's reach. ${ }^{37}$ (The territorial and paramilitary forces, while sustaining an important COIN mission, would continue to suffer numerous deficiencies long after 1964 and generally were not up to the challenge of fighting the Vietcong). ${ }^{38}$ This, in turn, reflected a larger problem: the challenge of "creating a unified strategy to deal with the growing threat to South Vietnam's stability and security." Part of what made that difficult, according to Daddis, was Diem's leadership. He cites U.S. Ambassador Elbridge Durbrow, who, in 1960, complained to the U.S. Department of State that Diem was "moving in all directions at once" without any plan to meet "the deteriorating internal situation." 39

Diem appears to have agonized over the decision about whether to heed MAAG's plan to build a large, conventional ARVN but ultimately decided to bow to U.S. pressure, fearing that the Americans might push him aside altogether to conduct the war effort and withhold the economic aid he badly wanted. ${ }^{40}$ Nation-building for Diem steeped as he was in contemporary modernization theory, was above all about economic development and industrialization. From 1956 on,

\footnotetext{
35 Daddis, 2014, p. 149.

36 Daddis, 2014, p. 151.

37 Daddis, 2014, p. 151.

38 Daddis, 2014, p. 154.

39 Daddis, 2014, p. 151.

40 Brigham, 2006, pp. 5-6; Wiest, 2007, p. 22.
} 
Diem would accede to more or less everything MAAG demanded, although that did not mean he heeded U.S. advice or followed through on anything he might have agreed to do. ${ }^{41}$ Another trend soon emerged in the early 1960s: The more Saigon and the ARVN faltered, the more the United States felt the need to insert itself, a process that Daddis argues initiated a vicious circle with respect to the eroding confidence in Vietnamese leaders and officers and the ramifications for their effectiveness. ${ }^{42}$

\section{The Growth of the ARVN and the U.S. Advisory Presence}

The U.S. presence and its role in the development of the ARVN grew rapidly. In late 1955, President Eisenhower increased the size of the MAAG by several hundred personnel. The Geneva Accords had limited the number of U.S. military advisors in South Vietnam to no more than 692 personnel; that total was reached by 1957. Additional U.S. military equipment was sent to South Vietnam, with the goal of creating seven infantry divisions, an airborne brigade, a marine brigade, support units, a small air force, and a small naval element. ${ }^{43}$ By the end of 1960, the number of U.S. military personnel assigned to the MAAG was still less than 1,000. By then, several U.S. advisors had been killed in South Vietnam.

The Kennedy administration initiated a major increase in U.S. presence in South Vietnam. The strength of the communist insurgency was growing in 1961-1962, years that saw the ARVN lose several battles to battalion-sized Vietcong units. In February 1962, the Military Assistance Command-Vietnam (MACV) was created under the command of GEN Paul Harkins. By the end of 1963, the size of MACV had increased to 16,260 U.S. personnel, including more than 1,400 Americans assigned as advisors to South Vietnamese units. Also by that time, the ARVN had been expanded to nine divisions, five separate brigades, 19 separate battalions, and more than 80 Ranger companies. Already, however, U.S. advisors were concerned that the

\footnotetext{
41 Brigham, 2006, p. 6.

42 Daddis, 2014, pp. 153-154.

43 Wiest, 2007, p. 22.
} 
quality and fighting abilities of many of the newly created ARVN units left much to be desired. ${ }^{44}$

The Americans' dim view of the ARVN as well as their continued focus on the conventional threat posed by North Vietnam resulted in a constant U.S. insistence that the ARVN grow in size. By late 1960, the ARVN had roughly 150,000 men. That total steadily grew, in large part because of constant pressure from Washington, primarily during the Johnson and Nixon administrations. MACV under Westmoreland pushed even more aggressively than MAAG. ${ }^{45}$ This is in contrast with KMAG, which, as we saw in the previous chapter, resisted Rhee's call to mobilize ever larger portions of the Korean population, in part out of concern for the U.S. military's capacity to sustain a growing ROKA and in part because U.S. authorities ultimately thought quality more important than quantity. They did not want the ROKA's growth to outstrip their ability to train it and provide it with suitably prepared commanders.

Nonetheless, the Tet Offensive spurred the United States to accelerate the ARVN's growth even more, an ambition that was reinforced when the Nixon administration embraced Vietnamization. As Brigham observes, "the focus clearly was on size, as if the ARVN might achieve some magical number that would change the balance of the war." By March 1968, the ARVN had 685,000 men, and that number increased to 801,000 by the end of 1970 . This total did not include several hundred thousand men in the so-called Popular Forces, the local militia units that defended villages and towns. By way of comparison, with an estimated population of 16-17 million, roughly the same as the ROK in this period, South Vietnam had far more men, by either raw numbers or as a percentage of the population, under arms by 1970 than the South Koreans ever had. ${ }^{46}$

The ever-increasing manpower needs of the ARVN resulted in greater use of conscription and ever-longer draft periods. In its early years, a considerable portion of the ARVN comprised volunteers-a

\footnotetext{
${ }^{44}$ Ramsey III, 2006, p. 28.

45 Brigham, 2006, p. 11.

46 Brigham, 2006, pp. 8-12.
} 
good sign for a new nation. However, as time passed and the army expanded, together with the need to replace battle casualties, conscription had to be expanded. Eventually, roughly 65 percent of the ARVN's men were drafted. Additionally, the draft periods were increased from two years to the duration of the conflict. Initially, 20- to 22-year-olds were drafted. In 1968, Thieu's government extended the draft age to 33. By the end of that year, one in six adult males in South Vietnam had either served in the ARVN or was still in uniform. ${ }^{47}$

\section{From Vietnamization to Collapse}

Vietnamization translated into an intense effort on the part of MACV—which had a field advisory strength of more than 14,300 Americans officers and noncommissioned officers (NCOs) assigned to the ARVN in 1970 - to grow the ARVN and push it into combat roles that heretofore the U.S. military had assigned to itself. ${ }^{48}$ In FebruaryMarch 1971, the ARVN conducted its first major operation without accompanying U.S. ground forces. Operation Lam Son 719 was an offensive into southern Laos to cut the so-called Ho Chi Minh Trail, the main communist supply route running from the North into South Vietnam. By this time, U.S. Congress had imposed significant restrictions on what actions U.S. troops could undertake, a response to Nixon's unilateral decision to invade Cambodia the previous year. Therefore, the ARVN units that advanced into southern Laos had to leave their MACV advisors at the Laotian border. The United States was, however, allowed to provide air and artillery support, including helicopters, to help the ARVN units as they advanced into Laos. Some of the best units in the ARVN, including the Airborne Division, Ranger units, and the ARVN's best-equipped armored brigade, participated in the operation.

Operation Lam Son 719 was a disaster for the ARVN. Recognizing the threat posed by enemy forces sitting astride their main supply

\footnotetext{
47 Brigham, 2006, p. 11.

48 Ramsey III, 2006, p. 34.
} 
route, the NVA launched violent, well-coordinated counterattacks. By mid-March, the surviving ARVN units had been driven back into northern South Vietnam with heavy casualties. Some ARVN units had panicked and been routed from the battlefield. ${ }^{49}$ The self-confidence and morale of the ARVN, which had never been particularly high, suffered badly from this defeat.

In April 1972, the communists launched their so-called Easter Offensive, a massive conventional attack to topple the Saigon government. By fall 1972, that offensive was brought to a halt following heavy South Vietnamese losses. Importantly, while almost all U.S. ground units had departed from Vietnam by that time, the ARVN was able to call on massive amounts of U.S. Air Force and U.S. Navy firepower from aircraft and ships. Some MACV advisors were also still in ARVN units during the Easter Offensive, and those men were key to coordinating U.S. firepower to help the ARVN units. By the end of 1972, however, the Americans had all departed. In spring 1975, the communists finally overran all of South Vietnam. The ARVN, at the time one of the world's largest standing armies, completely and rapidly collapsed.

\section{Why the ARVN Was Not the Nation-Building Force It Could Have Been}

As we discussed, South Vietnam's independence in 1955 initiated a race for the country's leaders to assemble something "coherent" out of a collection of ill-fitting parts. The race was primarily a political competition with obvious military aspects. The army needed to be a tool for nation-building in the sense that it would bridge the state and the nation, foster cohesion, promote state legitimacy and a particular national identity, and in general reflect the government's larger nationbuilding effort. That the ARVN appears not to have done those things reflects the failure of its leaders to craft a coherent political strategy,

49 For a good summary of Operation Lam Son 719, see James Willbanks, A Raid Too Far: Operation Lam Son 719 and Vietnamization in Vietnam, College Station, Tex.: Texas A \& M University Press, 2014. 
one that built ties between the population and Saigon and enabled the government to separate it from insurgents and stand up to northern aggression. Diem had many ideas—some good—and he achieved some successes; his successors clearly achieved less, particularly in the period of turmoil directly following his assassination. In retrospect, it is clear that removing Diem was a grave error, unless those involved had reason to believe that whoever succeeded him would be better at nation-building. But what matters for this report is the extent to which Vietnam's leaders failed to cultivate nationalism or another political ideology that could compete with the communists' ideals, and the ARVN by and large was not a part of a larger nation-building project. Rather than promote the government's legitimacy, the ARVN's expansion and operations weakened government legitimacy by dividing the population from the government and souring potential support for it.

\section{The Price of a Conventional Focus}

As we discussed, there is some controversy over the U.S. military's emphasis on building the ARVN into a conventional mirror of itself, leaving it ill adapted for COIN. In light of the conventional threat posed by communist main force units, which already were operating in large numbers in South Vietnam in the early 1960s, it seems that the U.S. preference was justified. That said, it must also be acknowledged that heavy-handed conventional operations come at a price with respect to the civilians among whom one is fighting. That price, moreover, is not trivial in the case of a fragile state with a weak claim to legitimacy. What appears to have happened in Vietnam is that the ARVN's approach to warfighting exacerbated its larger problem of its alienation from the population, or rather the population's alienation from the government.

For example, one often-cited problem with the ARVN's conventional focus was its heavy-handed tactics and reliance on firepower, combined with a relative disinterest in various civil-affairs operations and political activates commonly associated with COIN. The ARVN therefore tended to alienate people through the sheer destructiveness of its methods while doing little that might have mitigated the effect on popular attitudes. Phillips, writing about the same period, similarly 
noted that the ARVN seldom divided its divisions and usually conducted battalion-scale or larger sweeps of regular Vietcong forces. They were also, he said, overly reliant on airpower and indiscriminate interdiction shelling, which, he assessed, killed more civilians than Vietcong and did far more harm to the government's cause than good.50 Phillips claims he and his peers repeatedly brought this point to the attention of GEN Paul Harkins (U.S. commander in Vietnam, 1962-1964) and argued to anyone who might listen that "actions that do not contribute to winning the people contribute to losing the war," but to no avail.51 The situation, he argues, worsened under General Westmoreland when the U.S. direct-intervention period began, and U.S. carelessness alienated not just countless Vietnamese but the American public as well. ${ }^{52}$ Writing in 1971, Brian Jenkins observed that, by then, the ARVN's reliance on heavy weapons, because of their destructiveness,

[c]ontributed heavily to the South Vietnam army's . . . alienation from the people. As reliance on foreign technology replaced local support, the army grew indifferent to the people. When soldiers have helicopters, they seem to worry less about the disposition of the population along the roads they would otherwise have to travel. When they have armor, the attitudes of villagers seem less important. The indifference is reciprocated. Some people in South Vietnam have come to regard their own army as a foreign army, fighting according to an imported doctrine and entirely dependent on foreign support, or, according to the propaganda of Hanoi, as "puppets." Its destructive style of fighting coupled with the bad behavior of many of its soldiers cause the people to fear the army that is supposed to be defending them as a bigger threat to their own security than the enemy. ${ }^{53}$

\footnotetext{
50 Phillips, 2008, pp. 151-152.

51 Phillips, 2008, pp. 152-153.

52 Phillips, 2008, p. 153.

53 Brian M. Jenkins, A People's Army for South Vietnam: A Vietnamese Solution, Santa Monica, Calif.: RAND Corporation, R-897-ARPA, 1971, p. 9.
} 
Post-Tet saw the growth of calls among some Americans and Vietnamese for downsizing and restructuring the ARVN, both because it clearly had become too large to be sustainable over the long term and because of a begrudging understanding that replicating the U.S. Army would not lead to success even if the ARVN could sustain such a force. Jenkins, for example, explored the possibility of replacing the ARVN with a "people's army" in several papers dated 1970-1971, and cited a Vietnamese senator who argued that because American fighting methods failed, creating a Vietnamese army designed to fight like Americans would also fail, and thus what was required was a "third" way, namely a "people's army." 54

\section{Conscription: Driving a Wedge Between Army and People}

Another and perhaps larger problem was conscription itself. As mentioned earlier, because of American pressure, the Saigon government steadily expanded the size of the ARVN by resorting to increasingly draconian conscription policies that compelled a staggeringly large portion of the male population to serve indefinitely, meaning that the only options for getting out of the army were desertion, death, victory, or defeat. Saigon's conscription policies were devastating for the rural economy, as in the 1950s and 1960s, most of South Vietnam's population was still working the land, and the availability of the young men of the villages to support agriculture was critical. 55 They were devastating for rural society, based as it was on strong family units bound by filial and parental ties of love, respect, and obligation. Finally, they trampled over historical precedent and tradition, with devastating effects on state legitimacy: For centuries, leaders in Vietnam (including the French) had tried to balance the requirement to periodically mobilize peasant manpower for the military with the needs of peasant communities and families to manage their farms. ${ }^{56}$ It did not help that the ARVN had a

\footnotetext{
54 Brian M. Jenkins, The Politics of a People's Army, Santa Monica, Calif.: RAND Corporation, D-20531-ARPA, 1970b, p. 8.

55 Brigham, 2006, pp. 13-18.

56 Brigham, 2006, pp. 1-3.
} 
number of policies ranging from pay issues to leave policies that were entirely inimical to Vietnamese society. Brigham writes:

More frequent contact with families and villages should have been the cornerstone of any manpower plan. In the absence of proper ideological training, periodic contact with home was even more important.... In the battle for hearts and minds in South Vietnam, the [Republic] lost because it treated its own army with contempt.

The [Republic] never fully recognized the role of sons in rural Vietnam's patrilineal system. These young men were the caretakers of their families, yet once drafted into the army they became dependent on their families because of low pay, poor food, inadequate housing, and medical shortages. This dependency threatened to destroy the social fabric of rural South Vietnam. At the time when the [Republic] should have been reaching out to peasant families to try to make their lives better, it actually contributed to their misery. ... For this, rural Vietnamese never forgave and never trusted the [Republic]. ${ }^{57}$

One of the more striking differences between Saigon's policies and ARVN practices on one side and Hanoi's policies and NVA's practices on the other is that the North Vietnamese were sensitive to economic, cultural, and social sensitivities and managed to make a similarly onerous conscription scheme palatable and even positive for state legitimacy. According to Brigham, one way Hanoi did this was by making sure that "the army was a logical extension of the family and village." 58 They stressed the ties between peasant customs and the communist party's nationalistic cause, and they successfully appropriated and redefined traditional Vietnamese concepts such as the "people" and "nation" to extend the idea of familial obligations to the larger community and state. Brigham adds that the NVA strengthened this connection by replacing village elders with army officers in "key aspects of village life," such as conducting weddings and burials and providing

\footnotetext{
57 Brigham, 2006, p. 73.

58 Brigham, 2006, p. 3.
} 
financial support for the families of wounded soldiers. The army also supported agriculture, pitching in during harvests and conducting irrigation projects that "actually increased the rice yield in a time of war." Brigham continues,

The war took a toll on all sides, and certainly not everyone felt a bond with the NVA. . . . Still, if the result [on the communist side] fell short of an organic people's army with ties to Vietnam's past and reverence for the role of the family in national life, such an army was still the stated goal. In theory, the [NVA] and [Vietcong] were committed to the relationship of the individual to the army along traditional lines. As one former [NVA] general recalled, "Our goal was to remain true to Vietnam's past. We still held dear that notion that service in the army should not destroy family and village life. After all, that is what the war was all about.” During the French War (1945-1954), Vietnam's modern, anticolonial army functioned as a people's army, drawing support and inspiration from local communities. ${ }^{59}$

The communists also deliberately tied the war to the country's past and Vietnam's proud history of defeating more powerful enemies largely through tenacity. During the war with France, the Viet Minh named their operations after Vietnamese heroes of earlier resistance campaigns against the Chinese, and military authors in the 1960s continued to hold up historical heroes as examples that were relevant for the current struggle. ${ }^{60}$

The ARVN, however, was different, and in the rush to grow it and meet MACV's demands, Saigon "turned its back" on Vietnamese history and tradition:

The South Vietnamese government developed a conscription policy that defied both history and the reality of peasant life. In sharp contrast to the Communists, it did not tie the army to Vietnam's past. Nor did it show any empathy with the needs of

\footnotetext{
59 Brigham, 2006, p. 3.

60 Jenkins, 1970a, p. 3.
} 
peasant families. Instead, Ngo Dinh Diem, South Vietnam's first president, charted what he called "an independent course." That course would bring the ARVN into conflict with the people of South Vietnam and begin the process of alienation that would plague the army throughout its twenty-year existence. ${ }^{61}$

Jenkins in 1971 noted the cultural break between the ARVN and past practices and also argued that if the ARVN recruited forces for local service-basically a militia force, albeit it with greater training and equipment-the evidence suggested that they would do less damage to the economy by still being able to contribute to agricultural production, behave better toward civilian populations, fight better, and desert less often.

This is a good idea also since local soldiers tend to behave better because they are close to home and do not desert as often as soldiers serving far from their homes. Many South Vietnamese call this concept quan doi nhan dan, which means "army of the people," or "people's army," not because of any resemblance to socalled people's armies in China and North Vietnam but because of its greater reliance on human resources than on costly weapons, and on people defending their own homes than on full-time professional soldiers. ${ }^{62}$

\section{Cultural and Demographic Distance Between the ARVN and the People}

Exacerbating the alienation between the ARVN (and the state) and country's predominantly rural population was the makeup of the ARVN and the officer corps in particular. According to Allan Goodman's RAND report published in 1970, the ARVN's officer corps was more ethnically homogenous than Vietnamese society and drew its members from urban elites. Goodman observes that,

\footnotetext{
61 Brigham, 2006, p. 4.

62 Jenkins, 1971, p.13.
} 
$[\mathrm{r}]$ ather than serve as a means for integrating social forces, the officer recruitment policy has accentuated the gap between the government and the countryside. . . They are urban and educated ... unfamiliar with and unsympathetic to the peasants he is supposed to protect. . . His urban background and temperament have reduced the effectiveness of the RVNAF officer in bringing security to the countryside and have made winning the population's confidence more difficult. . . . The urban orientation of the Vietnamese officer differentiates him from the bulk of the rural population, and the educational requirement for commissioning tends to reinforce the gap between urban officer and peasant soldier. ${ }^{63}$

Goodman notes, among other things, "the peasant army is unwilling (often with good reason) to follow a 'Saigon cowboy'; the officer, in turn, generally seeks to avoid the hardships of rural and jungle life." 64

According to Goodman, the problem grew worse as the ARVN was increasingly tasked with "pacification" duties in the countryside, meaning it had to fight "the political war" and do what it could to foster ties between the people and the state. "Despite the growing importance" of the ARVN in rural development, he writes, "the urban outlook of most [ARVN] officers has hindered their identification with and empathy toward the bulk of the rural population." 65 It did not help, Goodman argues, that the "pacification" mission increased greatly opportunities for corruption and hindered the development of professionalism. ${ }^{66}$ Officers not only treated people badly, they stole the money earmarked for helping them.

\section{Politicization}

Many observers have noted that the high degree of politicization in the ARVN had a deleterious effect on its performance because, among

63 Allan E. Goodman, An Institutional Profile of the South Vietnamese Officer Corps, Santa Monica, Calif.: RAND, RM-6189-ARPA, 1970, p. 503.

64 Goodman, 1970, p. 27.

65 Goodman, 1970, p. 11.

66 Goodman, 1970, p. 13. 
other things, it affected who got promoted and why and poisoned the force's institutional culture. Part of the problem, according to Goodman, is that the ARVN was created before the kind of state required to operate such a force existed, meaning that its leaders often at least appeared to be more focused on internal political struggles than on building a force and fighting the enemy. ${ }^{67}$ The problem continued through the years, as ARVN leaders struggled among themselves and with others for political control, leading them, among other things, to assassinate Diem and then vie to succeed him. Officers interested in promotion benefited more from being politically connected and politically attuned than from effective leadership in the field. As Goodman notes:

The continuing involvement of the military in politics both feeds on and perpetuates factionalism in the officer corps. . . Indeed, political loyalty, not battlefield performance, has long dominated the promotion system in the officer corps, with the result that there is often an inverse relationship between rank and military skill. Morale is low among [ARVN] officers in the countryside who have stagnated for years in junior ranks while more politically favored and often-younger colleagues advance rapidly to posts in Saigon or provincial and Corps capitals. ${ }^{68}$

Goodman-writing in 1969-1970 as Vietnamization was in full swing-expressed the hope that Vietnam's leader at the time, Nguyen Van Thieu, would "begin now" to build a political base outside the ARVN so as to "insulate the officer corps from the vagaries of Vietnamese politics." 69

Jenkins's "people's army" idea that RAND analyzed during Thieu's administration indicated how unlikely it was that Goodman's wish would come true. Jenkins's assessment of the "politics" of the concept indicates that, even if Thieu were to back it, the Vietnamese presi-

\footnotetext{
67 Goodman, 1970, p. 25.

68 Goodman, 1970, p. vi.

69 Goodman, 1970, p. 30.
} 
dent would not do so to replace the ARVN with an army more attuned to the political project of nation-building and bridging the state and nation, but simply to generate a force that, while being more sustainable than the ARVN, would better suit his partisan political agenda. In other words, the point of creating a "people's army" would not be to foster cohesion and build bridges between the state and nation but rather to manage to political influence of particular factions within the military. As Jenkins phrased it, the concept had a "political logic" related to the president's desire to "free himself from the influence of generals who have independent power bases." 70 That is not the same thing as a "political logic" intended to win the political contest with Vietnam's communists.

\section{The Failure to Indoctrinate}

Among the myriad problems facing the ARVN was a failure on the part of the ARVN and Saigon's leadership to provide it with civic education and political indoctrination. Brigham associates this failure with low morale among the troops, resulting in poor performance, as well as a lack of popular support for the ARVN and the dedication among ARVN rank and file to the greater cause of saving South Vietnam from communism.

The problem, of course, relates to the larger one of the South Vietnamese republic's failure to develop a strong, positive identity and ideology beyond the negative ideology of anticommunism. Anticommunists such as Diem were working at a disadvantage given the communists' early success at dominating patriotic discourse as well as establishing their nationalist credentials. The communists elaborated compelling narratives that legitimized the northern government and explained what it meant to be Vietnamese and why patriotic Vietnamese should fight the southern government and its U.S. backers. Anticommunist nationalists certainly existed, but they failed to articulate compelling competing narratives and in general lacked the communists' unity. Diem arguably spent far more of his time fighting or suppressing rival nationalists than rallying them behind the larger nation-

70 Jenkins, 1970, p. 1. 
building cause. His successors' record is no better. South Vietnam was thus a government without a strong ideology behind it. Given this context, it therefore is not surprising that the ARVN did little to promote one.

The ARVN established no system of political control or education, and the training that did exist tended to focus on exposing the crimes and atrocities committed by the communists and to warn troops of communist propaganda..$^{71}$ The political training, moreover, fell short of addressing the relationship between the army, the people, and the nation, or anything having to do with the larger causes for which ARVN troops were being asked to fight, namely, the nation. ${ }^{72}$ According to Brigham, following Diem's assassination, political indoctrination ceased altogether until late 1965, when MACV helped establish a General Political Warfare Department that periodically launched national-education campaigns for the military and the general population. Department-sponsored campaigns included programs intended to improve small-unit leadership and prevent desertions though informal troop education and programs to improve the welfare of ARVN troops. Brigham notes, however, that "the discussions lacked the focus on the national question that all seemed to crave." According to one ARVN veteran Brigham cites:

What was missing from the new training programs was any notion of what our ideological program was. Anticommunism just seemed too reactive to us. We needed something that we stood for, not just notions of what we were against. ${ }^{73}$

To their credit, some in MACV were alarmed by the lack of ARVN interest in politics and pressed it to do more, but generally speaking, there was little follow-through. For example, writing of the 1963-1964 period, Phillips notes that MACV announced a program to encourage civic action by the ARVN, but it never got off the

\footnotetext{
71 Brigham, 2006, p. 42.

72 Brigham, 2006, p. 43.

73 Brigham, 2006, p. 43.
} 
ground. ${ }^{74}$ Phillips says that, at the time, he argued before MACV's G-3, BG Richard Stilwell, for "comprehensive civic-action indoctrination" of the sort that, he claims, had proven effective in Vietnam back in 1955 for improving soldiers' treatment of civilians in areas recently evacuated by the Viet Minh, but nothing came of his request. ${ }^{75}$ Years later, in 1969, MACV initiated a "For the People Campaign" to promote within the ARVN the idea that its mission was to protect the people, promote civic action, and improve military department and discipline. ${ }^{76}$ Another MACV-sponsored program pitted ARVN units in a competition against one another in civic-action programs. The intention, according to Brigham, was to link the ARVN to the people and the people to the ARVN. ${ }^{77}$ Such efforts all appear to have fallen into the category of too little, too late.

Interestingly, according to Brigham, ARVN soldiers perceived that rival efforts by the communists were vastly superior, that the communists were masters of the very kind of education they were lacking, and that the communists were the ones who were successfully promoting among the population links between (their) armed forces and the people. ${ }^{78}$ More to the point, ARVN soldiers appear to have decided that their enemies in fact not only did a better job of making their case but also had a better case, or at least had a case.

Lacking a sophisticated understanding of the ideological underpinnings of the war for South Vietnam, few ARVN troops believed that their cause was just. Because so many peasants associated the ARVN with the successors of the French Union forces, more should have been done to link the army to the countryside and to bring the soldiers and the people together in the national cause. A basic breakdown in political training meant that soldiers never fully understood why they should be motivated to surren-

\footnotetext{
74 Phillips, 2008, p. 152.

75 Phillips, 2008, p. 152.

76 Brigham, 2006, p. 44.

77 Brigham, 2006, p. 44.

78 Brigham, 2006, pp. 42-44.
} 
der themselves to commonwealth goals. Because political training failed to instill an ideological commitment to the struggle inside the armed forces, it was almost impossible for officers to rally men to the cause. Even more devastating for the South Vietnamese army, however, was the lack of camaraderie between individual soldiers; this too was a failure in training. ${ }^{79}$

The issue with camaraderie cited by Brigham relates both to a general failure of training and the lack of appropriate indoctrination. Forging individuals - above all when so many hail from rural communities - into cohesive units is a basic function of military training. Providing them with a new, positive identity is where training can overlap with indoctrination. As Brigham notes, the willingness to risk one's life is usually allied with esprit de corps associated with small units banded together by common experiences. ${ }^{80}$ In the ARVN's case, he argues, no effort was made to link the men to one another in any meaningful way:

There was no systematic training that explained the soldiers' connection to each other or to the nation. In the end, the absence of such training meant that the ARVN soldiers did not fight for each other. ${ }^{81}$

Brigham bases this claim on South Vietnamese as well as U.S. military sources. MACV, for example, repeatedly appealed to Saigon to address the ARVN's morale problems, to "link troops to one another," and to foster an understanding of "why they were fighting." Otherwise, battlefield disasters would continue. In one 1967 MACV report on "increasing the effectiveness" of the ARVN, for example, the authors urged Saigon to consider "altering basic training and unit training" to include the development of esprit de corps. For MACV, the root of the problem was the training officers themselves; they lacked the basic fundamentals and knew neither that they needed to attend to esprit de corps nor how to go about it. Saigon by and large ignored such advice.

\footnotetext{
79 Brigham, 2006, pp. 44-45.

80 Brigham, 2006, p. 46.

81 Brigham, 2006, p. 46.
} 
One reason, according to Brigham, who cites Vietnamese sources, was political intrigues that encouraged the government to fear the army and to fear political training. ${ }^{82}$ Saigon believed that political training would only encourage soldiers to act politically. Unfortunately, according to Brigham, the net result was not only a lack of cohesion but also the prevailing feeling among ARVN troops that they were on the losing side of history and that their communist opponents went to the field significantly better prepared. "It was not the fear of dying that paralyzed the troops but rather the fear that they were not ready for combat and an awareness that they were not as committed to the national cause." 83

Brigham marshals considerable evidence that ARVN soldiers felt little to no loyalty to Saigon, which had alienated them and proved itself time and time again to be contemptuous of them By 1968, most young men were doing everything they could to avoid the draft, and even the most committed anticommunists lost faith in their leaders. So why did the ARVN fight at all? According to Brigham, ARVN soldiers turned "inward to find something worth defending," their families. ${ }^{84}$

The young men who served in the ARVN had been socialized to be family members first and foremost. No talk of personalism or modernity could change the fact that most ARVN soldiers' primary loyalty was to their families. War did not alter this truth, except to intensify it among many. When things went badlyand they did early in the army's history-most soldiers resorted to doing all they could to protect their families and ensure their stability. The absence of training programs designed to cultivate this same intense loyalty to fellow soldiers and the nation was just one of the many shortcomings of South Vietnam's leaders. Interestingly, it was this loyalty to family and not to the government and its policies that kept soldiers in the army at all. ${ }^{85}$

\footnotetext{
82 Brigham, 2006, p. 47.

83 Brigham, 2006, p. 47.

84 Brigham, 2006, p. 109.

85 Brigham, 2006, p. 110.
} 
Brigham goes on to argue that ARVN soldiers redefined the meaning of the war and the purpose of serving in terms of increasing the odds that their individual families would survive. This, according to Brigham, resulted in a number of behaviors that vexed American advisors, among them the phenomenon of large numbers of camp followers_-soldiers' families — and high desertion rates, with soldiers often periodically leaving to help out their families and then returning. As the war went on, Brigham observed, it became more common for soldiers to bring their families with them "to the barracks doorstep" than desert to be with them. ${ }^{86}$

However, when things appeared to fall apart, as was the case in 1975, the ARVN crumbled especially fast because its soldiers-motivated above all by the desire to protect their families - fled with or to their families to lead them to whatever safety they could find. It was less "every man for himself" than "every man for his family."

Curiously, aside from Brigham, few scholars have examined the ARVN closely and made an effort to understand the roots of its morale and thus its performance problems. This stands in stark contrast to the numerous studies of the enemy, the NVA and the Vietcong, which have detailed extensively the communists' successful efforts drawing largely on the same traditional peasant stock and everything that implies to build and maintain morale, strong unit cohesion, and fidelity to the greater cause, all in the face of America's awesome firepower and despite often-grim conditions. ${ }^{87}$ RAND alone produced literally dozens of DoD-sponsored studies of NVA and Vietcong officers and men that looked into their morale and motivations - but only a few on the subject of the ARVN. One RAND report of the NVA by Anders Sweetland explored the question of why so few NVA defected by inter-

\footnotetext{
86 Brigham, 2006, p. 113.

87 See, for example, Jenkins, 1970b, p. 8. This is a summary of Goodman, 1970, p. 5. During the war, RAND generated numerous reports on the NVA and Vietcong that explored the importance of political indoctrination and the numerous mechanisms with which both the NVA and Vietcong cultivated and policed particular identities and values. See, for example, William Darryl Henderson, "The Vietnamese Army," in Morris Janowitz and Stephen D. Wesbrook, eds., The Political Education of Soldiers, Beverly Hills, Calif.: Sage Publications, 1983.
} 
viewing defectors and drawing on previous RAND work involving thousands of interviews with NVA and Vietcong defectors and prisoners of war. The number-one reason against defection was the NVA's excellent morale, which, the report insisted, was "not accidental": 88

The NVA gives careful attention to troop indoctrination. During his three months of basic training, each individual is given a minimum of two weeks of political indoctrination. As a result, each knows exactly why he is fighting, and each comes south anticipating that he may "die gloriously" for the cause. There is continuous, ongoing indoctrination throughout each man's military career. Every NVA company has a political officer whose authority is second only to the company commander's. It is his responsibility to insure that morale is kept high; he gives special attention before each campaign to assuring that each man enters battle in the proper fighting spirit. ${ }^{89}$

In addition, the NVA bolstered morale by organizing its forces into three-man cells about which the interviewed NVA defectors and prisoners of war spoke enthusiastically, which forged strong cohesion:

When a cellmate shows lack of enthusiasm, lowered spirit, homesickness, fear of death or discouragement, his fellows within the cell make every effort to help him overcome this. If they are not successful they will seek help from the squad leader, if the squad leader cannot resolve the problem, he takes it to the political officer. In these rare cases when the problem does not yield to one of these, the individual is removed from the fighting group so he cannot infect the others. ${ }^{90}$

Sweetland identified other mechanisms by which the NVA obtained compliance, including the recourse of threatening soldiers' family members with retaliation. However, Sweetland insisted that the

\footnotetext{
88 Anders Sweetland, Rallying Potential Among the North Vietnamese Armed Forces, Santa Monica, Calif.: RAND Corporation, RM-6375-1-ARPA, 1970, p. 2.

89 Sweetland, 1970, p. 2.

90 Sweetland, 1970, p. 3.
} 
evidence strongly suggested the importance of one factor in particular: belief in the cause. ${ }^{91}$ Patriotism, according to Sweetland, matters. ${ }^{92}$

An earlier RAND report-an attempt to profile the average NVA soldier in South Vietnam-made similar points. According to the author, Konrad Keller, the NVA soldier is thoroughly convinced of the justice of his cause, which has been stated very clearly to them. ${ }^{93}$ The rigors of living in South Vietnam and fighting American and South Vietnamese generate a degree of disillusionment, yet the vast majority of NVA troops—99 percent, to be exact—keep fighting. One reason is their faith in the cause. Another is "physical and psychological devices" used by military leaders to keep men in check, among them the threeman cell structure. ${ }^{94}$

Jenkins, as we have seen, argued late in the war that the ARVN had taken the wrong course and would be more effective as a "people's army." He based his argument on observations of low morale and bad behavior as well as on evidence that the troops did better when they were closer to home. Besides, the ARVN post-Tet had become undeniably unsustainable; Jenkins' vision of a "people's army" would be significantly smaller and cheaper.

Among the more striking aspects of Jenkins's arguments is his hesitancy to explore the idea of a "people's army" and his fear of comparisons with communist forces. He insists that he is appealing to a conservative model, not a revolutionary one:

The term "people's army" itself seems to offend many Americans. It sounds vaguely Communist. . . . The idea of a people's army has special appeal to the Vietnamese, for it is basically a return to the military institutions and techniques that for centuries enabled

\footnotetext{
91 Sweetland, 1970, pp. 3-4.

92 Sweetland, 1970, pp. 3-4.

93 Konrad Kellen, A Profile of the PAVN Soldier in South Vietnam, Santa Monica, Calif.: RAND Corporation, RM-5013-1-ISA/ARPA, June 1966, p. ix.

94 Kellen, 1966, pp. ix-x.
} 
Vietnam to preserve its independence against numerically and technologically superior enemies. ${ }^{95}$

Jenkins appears to deliberately refrain from considering the possibility of building a force comparable to the NVA for South Vietnam. North Vietnam, after all, featured more or less the same demographics and culture as South Vietnam. It also had a similarly draconian conscription policy. Yet it succeeded in taking villagers out of their local communities, knit them into cohesive and effective units, and dispatched them far from their homes to face great dangers without the problems associated with the ARVN. After all, there are plenty of examples of noncommunist nations that succeeded in uprooting young men from their local communities and replacing their solidarities with new ones focused on the unit, the army, and the nation at large.

\section{What MACV Got Wrong}

Brigham argues that, at various points in time, U.S. advisors and MACV in general raised the alarm regarding the ARVN's deplorable morale as well as the more specific problem of the lack of unit cohesion and cross-unit solidarity. The available evidence suggests, however, two things. First, with regard to morale problems, MACV's analysis focused mostly on what might be described as "administrative problems" related to food, housing, medical care, and pay, among other issues. This approach contrasts sharply with the extensive analytical work regarding the general ideology, politics, and motivation of the NVA and Vietcong. Second, MACV and its policymaking consumers in Washington, D.C., ultimately focused on force structure, size, and metrics of combat effectiveness. Phillips argues that, among U.S. advisors and policymakers, there was "little understanding" of "the need for a compelling political cause for our side, despite the example of an enemy whose every action served its political cause." ${ }^{96}$ In contrast, "the

\footnotetext{
95 Jenkins, 1971, p. 13.

96 Phillips, 2008, p. 223.
} 
prevailing mindset of American leadership was process oriented and mechanical rather than political and ideological." Daddis, in contrast, argues in his 2014 Westmoreland's War that American advisors and commanders had a good understanding of the larger political problems afflicting Saigon and the ARVN's myriad deficiencies, including problems with morale and support for the "cause." The problem was more one of not knowing what to do about them and failing in whatever efforts were made. In that context, perhaps the U.S. focus on concrete or tangible matters can be understood as reflecting a desire to focus on areas in which the Americans felt it could make a difference.

Goodman's study of the ARVN's officer corps, for example, focuses on administrative and especially economic issues, which it identifies as the root of the ARVN's morale problems. He noted, for instance, that the ARVN "provides few legitimate economic incentives to encourage the development of a sense of national duty and esprit de corps," as if such things were a function of economic factors. ${ }^{97}$ However, as for officers' "motivation" and "ideology," Goodman expressed the hope that future research will elicit data on those subjects. ${ }^{98}$ If we recall Henderson's arguments about the three forms of control, it appears that the focus for American advisors was squarely on "utilitarian control," meaning providing largely economic incentives and meeting physical needs, rather than "normative control," which he insists is the more powerful way to motivate soldiers to stand and fight. ${ }^{99}$ It was strong "normative control" that Henderson believes was the secret to the NVA and the Vietcong's resilience in the face of U.S. firepower.

Goodman also noted that, in general, there were three schools of thought regarding how well the ARVN was doing. There was a rosy "ARVN's rapidly improving" school, a more modest "progress is limited" school, and, finally, the "it's hopeless" school. ${ }^{100}$ Goodman observed that the first school grounded its analysis in the metrics col-

\footnotetext{
97 Goodman, 1970, p. 21.

98 Goodman, 1970, p. 23.

99 Henderson, 1979.

${ }^{100}$ Goodman, 1970, p. 24.
} 
lected by MACV related to "size plus combat effectiveness as measured by enemy body counts." 101 Goodman apparently took issue with this approach and argued for a more negative appraisal, based on his reading not of morale but of what he regarded as the officers' lack of "professionalism." "The immediate priority, therefore, should be to professionalize the corps in addition to the current program of modernizing force structure and firepower."

Daddis's study of the metrics of Vietnam confirms Goodman's assertion. His broader argument is that absent clear strategies regarding how to deal with what most experts at the time acknowledged as the political side of the war (i.e. nation-building and competing with the communists politically), American analysts, commanders, and strategists tended to fall back on matters with which they were more comfortable. These included conventional military operations, conventional measures of their effectiveness, and by and large all things quantifiable such as economic indicators. It often came down to numbers killed, operations undertaken, weapons seized, and the like. This was true of U.S. military operations, but it was also true of U.S. assessments of ARVN operations. Daddis argues that Vietnamization made matters worse by putting pressure on MACV to grow the ARVN, push it into combat, and herald its battlefield prowess:

As Americans viewed Vietnamization, the effectiveness of the South Vietnamese army became conflated with progress in the war, a mistake that ignored the problems of rooting out the Vietcong, creating lasting security, and developing a sense of national loyalty to the Saigon government. In turning over the conduct of the war to South Vietnamese forces, MACV defined progress in simplistic terms of allied combat effectiveness. As one report noted, "Combat is the final test." But was it?102

\footnotetext{
${ }^{101}$ Goodman, 1970, p. 25.

${ }^{102}$ Gregory A. Daddis, No Sure Victory: Measuring U.S. Army Effectiveness and Progress in the Vietnam War, Oxford: Oxford University Press, 2011, p. 173.
} 
Daddis observed that, while it might have been the case that the ARVN could fight well, it still faced myriad problems with corruption, desertions, morale, and the like. More important, according to Daddis:

Of greater significance, many ARVN soldiers lacked faith in their government, a fact that often led to young recruits deserting from their units. Thus, while U.S. advisors reported on tactical and operational weaknesses affecting combat effectiveness, the root causes of the ARVN's poor performance remained of peripheral concern. ${ }^{103}$

MACV's relative inattention to the ARVN's morale and its views of its own government bespoke a larger failure with respect to how the United States approached the conflict in general:

This bias in MACV reporting coincided with a larger omission in assessing the effectiveness of South Vietnam's government. Though counterinsurgency doctrine advocated coordination of political and military efforts, evaluating the GVN's political progress fell largely outside of [MACV's] reporting system. ARVN soldiers often felt little ideological bond to a government seemingly out of step with rural peasant life. American officers often overlooked this important element of morale and esprit de corps. In the countryside, MACV concentrated almost exclusively on collecting pacification statistics, failing to differentiate between military security and political legitimacy. Correspondent Robert Shaplen appreciated MACV's admirable efforts at the village level. "But we still have no philosophy of government, no fundamental sense of direction in which we are going, and, above all, no system of political organization, which must inevitably begin at the bottom. ${ }^{104}$

On the other hand, Daddis, in his more recent study of the war, offers that U.S. advisors were well aware of all of the problems afflicting ARVN and the Vietnamese government in general, but when they

${ }^{103}$ Daddis, 2011, p. 173.

${ }^{104}$ Daddis, 2011, p. 173. 
attempted to solve the problems, they tended to overestimate their ability to influence the Vietnamese. The example Daddis gives is a statement Westmoreland made in 1966 about the need to re-educate Vietnamese soldiers to change their poor attitudes toward the civilian population:

Such comments no doubt made sense. Proper relationships with the local population formed a central theme in counterinsurgency doctrine. Regardless of whether his ARVN general allies were receptive or not to this type of advice, Westmoreland overvalued his ability to make such sweeping changes among the South Vietnamese army's officer ranks. It seems unlikely Americans truly could "re-educate" their allies in any meaningful way. The decade-long advisory period before Westmoreland's arrival in Saigon alone suggested the limits of influence within the US training and education program. By mid-1967, little had changed. ${ }^{105}$

\section{Conclusion}

While it would be foolish to engage in reductionism regarding why South Vietnam lost the war to North Vietnam, there is a strong case for including, among the more important factors, the failure of Saigon and its U.S. advisors to build an army as a nation-building tool, one that both embodied and promoted a nationalist ideology. Instead of helping to unite Vietnamese soldiers within its ranks and serve as a bridge between the people and the state, the ARVN appears to have estranged the population from the state. The absence of proper political indoctrination, moreover, bespeaks several interrelated problems, namely a failure to have an appropriate nation-building agenda and a failure to understand the military's potential place in that project. The ARVN could not school its ranks in an ideology that supported the state in its fight against the communist north in large measure because it had none. South Vietnam's leaders, particularly after Diem, were not

${ }^{105}$ Daddis, 2014, p. 160. 
up to the task before them. Their communist foes, on the contrary, were master nation-builders who understood the importance of crafting a national army, knew how to do it, and could provide the required ideological content.

The ARVN's fate suggests a number of conclusions. Foremost among them is the importance of having an army be an adjunct of the nation-building project not just for the sake of that project but also for the force's effectiveness on the battlefield. Second, we find that a political nation-building strategy and an accompanying ideology are prerequisites. South Vietnam, like many postcolonial states, was born without a clear national identity; it became a nation in the absence of a coherent national ideology, a problem North Vietnam did not share. One implication is that there is little the United States can achieve with SFA if the host country itself has little interest in nation-building, misunderstands how to do it, and has neither the interest in nor the ability to shape its security forces such that they are subordinate to the larger political project of building the nation. In that case, the benefit for the United States of focusing on the issue of nation-building and the civic or républicain qualities of the force would have been a more accurate reading of the situation. One might have been less tempted to attribute as much significance to building force structure, for example, and more pessimistic even in the early 1960s about the value of ramping up SFA and Americanizing the war. 



\section{The Iraqi Army}

The Iraqi army has been at the center of efforts since Iraq's independence to build and determine the country's national identity. While it has at times served as a tool to help knit together Iraq's disparate ethnic and sectarian groups, the Iraqi army has also frequently undermined the state through a series of successful or attempted coups. When the army has been clearly subservient to the civilian regime, as it was under both Saddam Hussein and more recently Nouri al-Maliki, its loyalties have been tribal or sectarian, rather than institutional. It has never been a republican army, even after tremendous efforts by the United States to reform the army as a professionalized, apolitical force.

This chapter will first survey the historical development of the Iraqi army and its relationship with the state in the period from independence through the rule of Saddam. It will then investigate the period following the 2003 U.S. invasion of Iraq, when the army was disbanded and then rebuilt from scratch, including its subsequent deterioration under the Maliki regime that followed.

\section{0-2003: Building the Nation, Contesting the State}

The Iraqi army was built to be a key pillar of the new Iraqi state, acting as a symbol of national unity for the three former Ottoman provinces (vilayets). Initially supportive of the newly established Hashemite Iraqi monarchy that was imposed by the British, political divisions both within the army and with the monarchy began to undermine the army's support for the regime. In 1936, army officers staged their first 
coup and inaugurated a period of three decades of military interference in politics. This period came to an end in 1968 with the consolidation of civilian Ba'ath party rule. During the Ba'ath period, after 1979 under the leadership of Saddam, the military was kept subordinate to the state, and the regime took numerous steps to ensure that the army was "coup-proof." Although the army regained a measure of independent political identity in the final years of the Iran-Iraq war, by the mid-1990s, Saddam's control over the military had been restored. This period ended abruptly in 2003 with the U.S.-led invasion that both toppled the regime and defeated-and then disbanded-the Iraqi army.

\section{Political Comportment of the Army and Relationship with Civilian Authority}

The degree of deference for and support of the civilian administration by the Iraqi army varied considerably over the first 80 years of its existence. In the years immediately following the establishment of the British Mandate in Iraq in 1920, the newly constituted Iraqi army was respectful of its subordinate relationship with the civilian regime, the Hashemite monarchy of King Faisal I. ${ }^{1}$ The army also was initially quite small and not the dominant armed force operating inside Iraq. ${ }^{2}$ As the Iraqi army gradually increased in stature and size, due in part to its role as the defender of Iraqi national identity, the army began to disagree more vocally with the policies of the government. ${ }^{3}$ The two main dividing issues were whether to accept the continued British guidance

1 Andrew Parasiliti and Sinan Antoon, "Friends in Need, Foes to Heed: The Iraqi Military in Politics," Middle East Policy, Vol. 7, No. 4, October 1, 2000.

2 In addition to sizable numbers of British and Indian troops that remained in Iraq after the end of the First World War, Britain also maintained the Iraqi Levies, a colonial force drawn primarily from the Assyrian community that was not answerable to the Iraqi government. See Daniel Silverfarb and Majid Khadduri, Britain's Informal Empire in the Middle East: A Case Study of Iraq 1929-1941, Oxford: Oxford University Press, 1986, p. 48.

3 Troublingly, the event that most boosted the political profile of the Army occurred when it massacred both armed and civilian Assyrians in 1933. The Assyrians were widely resented and seen as a tool for ensuring British influence in Iraq even after the formal end of the British mandate in 1932. See Sami Zubaida, "Contested Nations: Iraq and the Assyrians," Nations and Nationalism, Vol. 6, No. 3, 2000, pp. 368-370. 
of Iraqi foreign and security policy (as the monarchy did) and whether the focus of the regime should be on supporting the development of a narrowly Iraqi national identity and regime or a broader pan-Arabic identity and regime. ${ }^{4}$

These divisions undermined the army's support for the regime. This and particularly anti-British nationalist sentiment led to the first coup in Iraq in 1936, at which time the army positioned itself as the ultimate arbiter of national policy. 5 This role persisted until 1941, when the army attempted to oppose British interests and military policy during World War II and was defeated by British troops, who restored the primacy of the monarchy. ${ }^{6}$ While British power was able to again subordinate the Iraqi army to the state, the rift between the monarchy and military leaders remained. A final coup in 1958 that involved the murder of King Faisal II and most of the royal family spelled the end of the monarchy and the beginning of direct military rule. ${ }^{7}$ During this period, significant political disagreements persisted:

What united the army and these parties was their opposition to the monarchy, but once the Free Officers were in power, they had no systematic program, nor ideology to unite these factions. Even the officers themselves were part of a military government that had its own divisions between Iraqi nationalists, pan-Arabists, Baathists and Communists. The Free Officers had to deal with the emergence of rival political parties and factions that erupted on the scene after the collapse of the monarchy, and strife

\footnotetext{
4 The latter identity conceived of Iraq as an "Arab Prussia" that would lead to the unification of Arabic lands in the same way that Prussia unified the disparate German states in the middle 19th century. See Ibrahim Al-Marashi and Sammy Salama, Iraq's Armed Forces: An Analytical History, New York and London: Routledge, 2008, p. 28.

5 Mohammad A. Tarbush, The Role of the Military in Politics: A Case Study of Iraq to 1941, New York: Routledge, 1982, pp. 121-129.

6 Matthew Elliot, 'Independent Iraq': The Monarchy and British Influence, 1941-1958, London: Tauris Academic Studies, 1996, pp. 14-18.

7 Marion Farouk-Sluglett and Peter Sluglett, Iraq Since 1958: From Revolution to Dictatorship, London: I. B. Tauris and Co Ltd, 2001, p. 49.
} 
between Arab nationalists and Communists was a dominant feature of [the] regime. ${ }^{8}$

The relative influence of these political factions was resolved convincingly in 1968, when the nationalist and civilian Bath party consolidated its rule and the army again took on a subordinate role. ${ }^{9}$

During the Ba'ath period, and particularly during the rule of Saddam after 1979, the regime took numerous steps to ensure that the army did not develop its own corporate loyalty or seek to challenge Ba'ath dominance of the state. These steps included basing promotions on personal or tribal loyalties, monitoring the political leanings of officers through domestic intelligence agencies, creating parallel institutions outside the regular military (such as the Republican Guard) that could counterbalance the regular army, and centralizing all military decisionmaking in the hands of Saddam. ${ }^{10}$ After it was effectively "coup-proofed" in this manner, the army served as a key pillar of the Ba'athist state, both symbolically and as a means of repressing internal dissent, although the Republican Guard, rather than the regular army, increasingly performed this function. ${ }^{11}$ While these coup-proofing efforts were successful in preventing internal challenges to the regime, they also hampered the Iraqi army's military effectiveness, leading to a near-defeat in the Iran-Iraq War until they were partially eased in that war's final years. ${ }^{12}$ However, this easing, which included giving individual commanders and army units greater autonomy, encouraged junior officers to feel a sense of loyalty to the army and nation but not necessarily to the Ba'ath regime. The easing also contributed to several

8 Al-Marashi and Salama, 2008, pp. 78-79.

9 Al-Marashi and Salama, 2008, pp. 230-231.

10 For a discussion of coup-proofing efforts in Iraq, Saudi Arabia, and Syria, see Elliot, 1996, pp. 14-18; James T. Quinlivan, "Coup-Proofing: Its Practice and Consequences in the Middle East,” International Security, Vol. 24, No. 2, Fall 1999.

11 Al-Marashi and Salama, 2008, p. 184.

12 Al-Marashi and Salama, 2008, p. 150. 
attempted coups in early 1990s before Saddam was able to undo the changes and reassert total control. ${ }^{13}$

\section{Demographics and Reflection of Society}

Demographic divisions within the Iraqi army both contributed to and reflected political and ideological divisions within the country. Officers with previous experience and training from the Ottoman military tradition initially dominated the Iraqi army, primarily Sunnis (mostly Arabs, but with some Kurds) with very few Shia or Christians. ${ }^{14}$ Sunnis from towns in the country's northeast, such as Tikrit, were especially likely to join the military because of economic factors. ${ }^{15}$ For enlisted men, however, the army initially drew primarily from Sunni tribesmen, and the British, who feared that a larger Iraqi army would prove more difficult to control, resisted mass conscription. ${ }^{16}$ Following the end of the British Mandate, the Iraqi army did institute conscription in 1935, which helped to ensure that the lower ranks more closely reflected the country's underlying demographics, including greater numbers of Shia and Kurds. ${ }^{17}$

The ideological divisions that developed within the army in part reflected the demographics of the officer corps. Sunni Arab officers were more supportive of pan-Arabic ideologies than the Kurds, for example, although officers from both groups frequently resented the continuing British interference in Iraqi affairs. In the Ba'athist period, meanwhile, Sunni tribal identities became increasingly relevant, not because they reflected salient sectarian or religious identities or ideologies of the state, but because they formed a basis on which personalized trust could be established as formal and institutional loyalties

\footnotetext{
13 Al-Marashi and Salama, 2008, p. 174.

14 Tarbush, 1982, pp. 78-79; Al-Marashi and Salama, 2008, p. 40.

15 The imposition of an international border with Syria disrupted traditional trade relationships with Damascus and means of livelihood, giving young men from these towns few economic alternatives. They were also particularly likely to be pan-Arabist in their political orientation. See Al-Marashi and Salama, 2008, p. 38.
}

16 Tarbush, 1982, p. 79.

17 Al-Marashi and Salama, 2008, p. 33. 
were intentionally broken down. While Sunni Arabs also tended to predominate in Saddam's regime and military, this was not because of any particular Sunni sectarian loyalty or fervor, but rather because of the predominance of Saddam's Albu-Nasir tribe. ${ }^{18}$ Regardless of the origins of the predominance of Sunni officers, however, once established, it meant that those with the most to lose from Saddam's fall from power were disproportionately Sunni, and those with the most potential to gain from a change in regime were Shia or Kurdish, a division that was reflected in the uprisings and subsequent repressions of the early 1990s. ${ }^{19}$

\section{Identity and Identity Formation}

The Iraqi army played a role in strengthening the Iraqi sense of national identity, particularly during the Iran-Iraq War, but identity divisions within the army itself did at times also play a role in undermining the stability of the Iraqi state. The new monarchy intended the army to play an important initial symbolic role in the project to build the newly independent Iraq:

[The monarchy] envisioned conscription as a means to cement the public's loyalty to a patriotic, professional army that would incorporate Iraqis of all sects and ethnicities, as well as urban, rural and tribal elements into a cohesive national institution. The elites believed that the image of a [sic] independent Hashemite Iraq would be projected and imbued into the soldier, a new model Iraqi citizen, who after his military service would take those ideals into civilian life. ${ }^{20}$

Despite these intentions, however, the army did not become a "monarchical army" that supported an ideology that would have justified continued Hashemite rule in Iraq. Instead, army officers became increasingly supportive of both anti-British and pan-Arabic national-

\footnotetext{
18 Farouk-Sluglett and Sluglett, 2001, p. 49.

19 Al-Marashi and Salama, 2008, p. 184.

20 Al-Marashi and Salama, pp. 24-25.
} 
ist ideologies, neither of which could be fully supported by the monarchy. ${ }^{21}$ The Iraqi army was successful in acting as a symbol of and vehicle for rising Iraqi nationalism, particularly after the massacre of Assyrians in 1933.22 However, this nationalism was fundamentally in tension with the British Mandate and Britain's continued role in Iraq even after formal independence in 1932, positions to which the monarchy was ultimately committed. While the country and the army therefore did begin to develop a national identity in the decades after independence, it was an identity that was difficult to reconcile with support for a British-imposed monarchy. After a series of coups and counter-coups beginning in 1936, including a British military invasion to restore the monarchy in 1941, this tension was finally resolved in the 1958 coup that led to the murder of the king and most of the royal family and the permanent removal of the monarchy. ${ }^{23}$

As noted, 1958-1968 period was one in which numerous contending ideologies within the army jockeyed for influence, including Ba'athism, communism, and pan-Arabic and Iraqi nationalism. ${ }^{24}$ This contest was resolved definitively in 1968 with the consolidation of nationalist Ba'th party rule. Ba'ath ideology, originating in Syria, was rooted in an areligious pan-Arabic nationalism, but a political split with the Syrian Ba'th regime limited the potential for any such project. ${ }^{25}$ Under Saddam, Ba'athism was gradually drained of its positive goals and reconstructed as an ideology whose sole goal was the preservation of the totalitarian state under Saddam's control, flexibly appealing to nationalist or religious sentiments as deemed necessary. ${ }^{26}$ The army itself, meanwhile, was vigorously depoliticized as officers were

21 Michael Eppel, "The Elite, the Effendiyya, and the Growth of Nationalism and Pan-Arabism in Hashemite Iraq, 1921-1958," International Journal of Middle East Studies, Vol. 30, No. 2, May 1998.

22 Zubaida, 2000, pp. 368-370.

23 Al-Marashi and Salama, 2008, pp. 69-76; Farouk-Sluglett and Sluglett, 2001, p. 49.

24 Al-Marashi and Salama, 2008, pp. 78-79.

25 John F. Devlin, “The Baath Party: Rise and Metamorphosis," American Historical Review, December 1991.

26 Devlin, 1991, p. 1407. 
taught to fear any hint of political disagreement with the regime as part of the "coup-proofing" process. ${ }^{27}$

While prevented from becoming a vehicle for alternative ideologies, the army still served as a symbol to promote national unity and pride, particularly during the devastating Iran-Iraq War. However, while the army's conduct during the war likely strengthened Iraqi nationalism, the growing awareness of how poorly the army was being led also undermined support for the regime:

During the war the Army served as a renewed means of socialization of Iraqis, harking back to the days of King Faysal and his coterie's vision of the role of the military in early Iraqi society. During the war young conscripts come [sic] into contact with Iraqis from various parts of the nation and engaged in a collective endeavor of defending the nation. This common bond forged among fighting men strengthened their sense of Iraqi nationalism, although it did little to strengthen Baathism. The values of Arab socialism and the defense of the Party had little emotional value to the men on the front, as the Baath was blamed for poor battlefield management, interference in military affairs and the presence of ubiquitous Party commissars. ${ }^{28}$

The Iraqi regime took steps to strengthen popular attachment to both the regime and the army during the war, such as publicly_-and lavishly_compensating the families of soldiers who died in combat. ${ }^{29}$ As the war dragged on far longer than anticipated, however, such steps became difficult to maintain, and the high levels of casualties (particularly in the Shia community) sapped popular support for the conflict. ${ }^{30}$

However, Iraqi Shia did not abandon the army during the fighting with heavily Shia Iran, even while much of the fighting took place in majority Shia areas. Iraqi Shia remained mostly loyal to Iraq, even in

\footnotetext{
27 Al-Marashi and Salama, 2008, p. 129.

28 Al-Marashi and Salama, 2008, p. 150.

${ }^{29}$ Lisa Blaydes, "Iraqi Nationalism and the Iran-Iraq War," promeps.org (Project on Middle East Political Science), March 10, 2015.
}

30 Blaydes, 2015. 
the face of harsh conscription methods and devastating casualties. ${ }^{31} \mathrm{By}$ the end of the war in 1988, the army appeared to have played a crucial role in promoting an Iraqi pride and nationalism that did cross sectarian lines. ${ }^{32}$

While pride in the army may have crossed sectarian lines, loyalty to Saddam's regime-particularly after the defeat in the 1991 Gulf War-most certainly did not, as the later revolts in the Shia and Kurdish areas attest. It is therefore all the more important to note that an Iraqi national identity that transcended these divisions had developed over the 70 years since independence, that this identity had helped to play a role in holding the nation together during some of its worst crises, and that the army had been an important contributor to the development of this identity. The durability of this national identity would be severely tested in the aftermath of the American-led invasion in 2003 that removed Saddam from power and led to a fundamental reordering of the politics of the country.

\section{3-2014: Rebuilding the State, Dividing the Nation}

The U.S.-led invasion of Iraq in 2003 led to the total defeat of the Iraqi army. After a short period of sometimes heavy fighting, most Iraqi army units dissipated, and coalition units were able to secure Baghdad with relatively little resistance. ${ }^{33}$ As the United States began to consider what sort of regime to put in place in post-Saddam Iraq, it was also

\footnotetext{
31 Al-Marashi and Salama, 2008, p. 151.

32 Al-Marashi and Salama, 2008, p. 150. Notably, other analysts have suggested that the lack of a Shia revolt during the war had more to do with the fragmentation of the Shia community and lack of sectarian identity that could be used to mobilize the community than strong Iraqi nationalism. See Shahram Chubin and Charles Tripp, Iran and Iraq at War, London: I. B. Tauris and Co., 1988. Ironically, the war and the high cost in Shia casualties may have helped to overcome these difficulties and precipitate the Shia uprisings against Saddam's rule following the 1991 Gulf War.

33 For an overview of the military campaign in 2003, see Michael R. Gordon and Bernard E. Trainor, Cobra II: The Inside Story of the Invasion and Occupation of Iraq, New York: Vintage, 2006.
} 
faced with the decision regarding on what lines to reconstitute the Iraqi army. In some ways, this dilemma harkened back to the British experience in Iraq after the First World War. Both external powers initially saw the advantages of establishing an Iraqi army that was smaller in size and limited in its mandate, so as not to threaten neighboring states or the civilian regime they were planning to leave in place. ${ }^{34}$ While the early Iraqi army later expanded despite British objections, the United States quickly shifted its plans and set about constituting and training a greatly expanded Iraqi military as a necessary component of its plans to fight a growing insurgency. The U.S. efforts to constitute this new Iraqi army will be the focus of the remainder of this chapter. Before turning to those efforts in detail, however, it is important to revisit the crucial U.S. decision made in the early days of the occupation of Iraq: the decision to disband the original Iraqi army.

\section{Starting from Scratch: Disbanding the Iraqi Army}

U.S. planning for postwar Iraq had originally called for reconstituting certain units of the Iraqi army to serve as the nucleus for a new force. ${ }^{35}$ While significant changes were envisioned regarding the officer corps and ethnic makeup of such a force, it was seen as potentially valuable as a supplement to U.S. forces that were already stretched thin. By May 2003, U.S. officials were engaged in detailed discussions with Iraqi officers regarding reconstituting their units within the new force. ${ }^{36}$ Such a plan was a logical continuation of U.S. messaging prior to the invasion, which aimed to persuade Iraqi forces not to fight to protect Saddam in exchange for having a place in the postwar order. ${ }^{37}$

\footnotetext{
${ }^{34}$ For a discussion of these similarities, see Al-Marashi and Salama, 2008, p. 9. On the initial plans for a small new Iraqi army, see Nora Bensahel, Olga Oliker, Keith Crane, Rick Brennan, Heather S. Gregg, Thomas Sullivan, and Andrew Rathmell, After Saddam: Prewar Planning and the Occupation of Iraq, Santa Monica, Calif.: RAND Corporation, MG-642-A, 2008.

35 James P. Pfiffner, "U.S. Blunders in Iraq: De-Baathification and Disbanding the Army," Intelligence and National Security, Vol. 25, No. 1, 2010.

36 Pfiffner, 2010, pp. 81-82.

37 Nir Rosen, "What Bremer Got Wrong in Iraq," Washington Post, May 16, 2007.
} 
The decision announced on May 23, 2003, to disband the Iraqi army caught many U.S. officials by surprise, to say nothing of the reaction of now-ostracized Iraqi soldiers. ${ }^{38}$ L. Paul Bremer III, the head of the Coalition Provisional Authority, has generally offered two rationales for the decision: that disbanding the Iraqi army merely recognized a fait accompli because, by that time, no intact units of the Iraqi army remained and much of the infrastructure supporting the force had also been destroyed, and that disbanding the Iraqi army was necessary to reform the military and send a signal to the Iraqi people that the new Iraqi security services would be different from the old and not engage in similar abuses. ${ }^{39}$

This decision has since been strongly criticized as helping to provide the recruits that would sustain the lengthy insurgency that followed. ${ }^{40}$ The first rationale for the decision, that Iraqi units had "demobilized themselves" by disbanding rather than offering sustained resistance to U.S. forces and that there had been widespread looting of military bases to which reconstituted forces might be recalled, is somewhat undercut by the fact that however weak the Iraqi army as an institution was at the time, the alternative was to replace it with something that did not yet exist at all. ${ }^{41}$

The second rationale, that the Iraqi army was so strongly disliked for its association with Saddam's repressive policies that its elimination was politically necessary, deserves close scrutiny for the purposes of our discussion. U.S. officials argued that the army was essentially a Sunni institution, and that Shia and Kurds would have responded negatively to any attempt to reconstitute it. ${ }^{42}$ As such, the symbolic destruction

38 Michael R. Gordon, "Fateful Choices on Iraq Army Bypassed Debate," New York Times, March 17, 2008.

39 L. Paul Bremer III, "How I Didn't Dismantle Iraq's Army," New York Times, September 6, 2007.

40 Pfiffner, 2010.

41 Peter W. Galbraith, “The Mess,” New York Review of Books, March 9, 2006.

42 Bremmer, 2007. It is important to note that the pre-2003 Iraqi army was in fact made up of significant numbers of Shia and Kurds, as well as Sunnis. See Al-Marashi and Salama, 2008, p. 33. 
of the Iraqi army was regarded as a positive development on its own merits, regardless of its other consequences, as a new, more inclusive Iraqi army could now be built without being tainted by its association with the past.

There is, however, little evidence to suggest that Iraqis viewed the army in such an overwhelmingly negative or sectarian manner. For example, while elite units such as the Republican Guard were closely associated with violence against civilians and were not considered for recall, other regular Iraqi army units were as often a source of resistance to Saddam's regime. ${ }^{43}$ Moreover, the institution of the Iraqi army as a whole remained one of the few symbols of the nation that did command some allegiance from different ethnic and sectarian communities. ${ }^{44}$ Its dissolution helped lead to the rise of local militias through the worsening the security vacuum in the country. It also established a pool of idle young men with military training, likely accelerating the division of Iraqi society along communal lines-a theme that has dominated much of the political and security situation in the country since. ${ }^{45}$

The other major decision in May 2003 — to pursue a far-reaching de-Ba'athification campaign-was also problematic in that it forced many badly needed government employees, such as schoolteachers, out of work. ${ }^{46}$ In principle, such an effort need not have necessarily exacerbated identity divisions in the country, as millions of Bath party members in 2003 were in fact Shia. ${ }^{47}$ However, the manner in which the campaign was conducted led to significant communal tensions, exacerbating the sense of grievance within the Sunni community that they were being unfairly identified with Saddam's regime. ${ }^{48}$

\footnotetext{
43 Parasiliti and Antoon, 2000, p. 138.

44 Bremer III, 2007.

45 Tareq Y. Ismael and Jacqueline S. Ismael, Iraq in the Twenty-First Century: Regime Change and the Making of a Failed State, London: Routledge, 2015, pp. 62-63.

46 W. A. Terrill, Lessons of the Iraqi De-Ba'athification Program for Iraq's Future and the Arab Revolutions, Carlisle Barracks, Pa.: U.S. Army War College, Strategic Studies Institute, 2010.

47 Ismael and Ismael, 2015, pp. 62-63.

48 Terrill, 2012, p. 25.
} 
The U.S. tendency to view ethnic and sectarian identities as the main, if not the only, relevant identities in Iraq was therefore highly problematic. ${ }^{49}$ Such an approach, exemplified by the application of the de-Ba'athification process, made an enemy of many non-Tikriti Arab Sunnis who had also suffered at the hands of Saddam, but who would now be effectively treated as culpable regime insiders. The new Iraqi political system also encouraged sectarian identities—such as by dividing the positions of president, prime minister, and speaker of the parliament rigidly among the three major communities—and minimalizing the nationalist or pan-Arab identities that had previously been common. ${ }^{50}$

The approach toward the Iraqi army was similarly problematic. In reality, the Iraqi army was not simply a Sunni force responsible for the repression of Shia and Kurds:

To see the Iraqi Army as a monolithic unit as Bremer did when he disbanded it revealed a lack of knowledge of the tensions within the Iraqi armed forces. It also revealed Bremer's simplistic notions of Iraq's ethno-sectarian divide, ignoring the cleavages within Iraq's communities. Sentiments towards the Iraqi Army varied and they were by no means uniform within various Iraqi sectarian or ethnic communities. The CPA [Coalition Provisional Authority] view of the Army along ethnic and sectarian lines did not factor in more visible fault lines in the Iraqi military, such as class, rural-urban, religious-secular and tribal divisions within the armed forces. Some Shia regarded the military as an institution responsible for brutal domestic repression and discrimination in favor of the Sunni Arabs, but other Shia were loyal to this institution and even took part in Shia repression against fellow Shia. The Baath government could not have survived as long as

\footnotetext{
49 Harith al-Qarawee, "The Rise of Sunni Identity in Iraq," The National Interest, April 5, 2013.

50 International Crisis Group, Make or Break: Iraq's Sunnis and the State, Brussels, No. 144, August 14, 2013; Harith Hasan Al-Qarawee, Iraq's Sectarian Crisis: A Legacy of Exclusion, Washington, D.C.: Carnegie Middle East Center, 2014.
} 
it did without Shia and Kurds taking part in security forces to repress other "rebellious" Shia and Kurds. ${ }^{51}$

The U.S. decision to eliminate the institution of the Iraqi army, still a source of pride for many Iraqis, including particularly Sunnis, helped to encourage precisely the sorts of divisions that the United States had sought to reduce by building a new Iraqi army whose officer corps was more representative of the country. The widespread estrangement of the Sunni community from the post-2003 Iraqi regime, while certainly linked to other factors, has become one of the most fundamental obstacles for attempts to build an effective Iraqi state and army.

\section{Training the New Iraqi Army}

After the decision was made to disband the old Iraqi army, it fell to the coalition, and primarily the United States, to create a new Iraqi army to take its place. The resulting effort to constitute and train the new Iraqi army went through several phases, as the coalition learned as it went and adapted to changing circumstances, most notably the growth of the insurgency. 52

This new army was initially conceived of as a small, defensive force with an end-strength of approximately 40,000.53 Training of local security forces had historically been the domain of the U.S. special forces, but they were not of sufficient size in Iraq to perform both this mission and their ongoing operational responsibilities. The United States therefore gave a $\$ 48$ million contract to the Vinnel Corporation, which in turn subcontracted to MPRI, Inc., to provide trainers and other support for the effort. ${ }^{54}$ Training for these forces focused on

\footnotetext{
51 Al-Marashi and Salama, 2008, p. 203.

52 There was also a proliferation of different security actors in Iraq in this period, including the Iraq Intervention Force, the Iraqi Civil Defense Corp, the Iraqi National Guard, as well as the Iraqi Police Service and the regular Army. These forces received heterogeneous types and levels of training. This report will focus only on training for Iraqi army units to retain the greatest utility for comparison with other cases. Typically, however, training for other units was less intensive.
}

53 Bensahel et al., 2008, pp. 141-142.

54 Bensahel et al., 2008, p. 142. 
defending Iraq against external threats. ${ }^{55}$ After many units of the new Iraqi army failed to fight alongside coalition forces in the first battle of Fallujah in April 2004, the program for new units was adapted to include more emphasis on counterinsurgency training. ${ }^{56}$ In addition, the decision was made in June 2004 to move the training of the Iraqi security forces, including the army, under the newly created Multinational Security Transition Command-Iraq (MNSTC-I). ${ }^{57}$

The MNSTC-I was given a greatly expanded set of resources to train significantly larger security forces, including both the army and the National Guard. While the total number of security forces expanded rapidly, exceeding 60,000 by fall 2004, the number of trained and available regular army personnel remained modest at less than 3,000.58 Training for army personnel consisted of an eight-week course for recruits without prior military training and a three-week course for those that had previously served in the Iraqi military.59 This training was primarily focused on operational skills:

Iraqi Army soldiers negotiate the standard eight weeks of basic training including basic soldiering skills instructions in weapons, drills, ceremony, soldier discipline, and physical training. Units negotiate advanced follow-on infantry, land navigation, and other operational training after graduation and before deployment. ${ }^{60}$

In addition, the United States began to place a greater emphasis on embedding U.S. troops with Iraqi units to increase their effectiveness and ability to call on other U.S. assets such as air support. ${ }^{61}$ U.S.

\footnotetext{
55 Bensahel et al., 2008, p. 147.

56 Bensahel et al., 2008, p. 147.

57 Anthony Cordesman, Iraqi Security Forces: A Strategy for Success, Westport, Conn.: Praeger Security International, 2005, p. 66.

58 Cordesman, 2005, p. 96.

59 Cordesman, 2005, p. 97.

60 Cordesman, 2005, p. 108.

61 James Fallows, "Why Iraq Has No Army," The Atlantic, December 2005, p. 72.
} 
troops embedded in this manner continued to train and mentor Iraqi units on operational issues as well as ethics and professionalization. ${ }^{62}$

By 2007, with violence from the insurgency reaching critical levels, a number of further adaptations took place, alongside the "surge" of greater numbers of U.S. forces into Iraq. ${ }^{63}$ The goal for the total number of Iraqi security forces available was expanded to $650,000 .^{64}$ Recruitment into the Iraqi army accelerated dramatically, with 14,000 new recruits joining every five weeks by early 2008. ${ }^{65}$ By the end of 2008, the total size of the Iraqi army approached 200,000. ${ }^{66}$ Moreover, training for the Iraqi army became iterative, with an initial set of basic training and squad and platoon combat skills, of approximately 12 weeks, followed by combat deployments. ${ }^{67}$ Units were then further trained while deployed by embedded trainers and rotated through training facilities after having seen combat. ${ }^{68}$ The focus of this training was operational, although embedded trainers did continue to address professionalization issues and work to deter violence against civilians. ${ }^{69}$ These procedures aimed to maintain or potentially increase the amount of training that units eventually received, while still making units available for use by commanders as quickly as possible.

\footnotetext{
62 Interview with former senior advisor to U.S. forces in Iraq, March 2015.

63 For context, see Thomas E. Ricks, The Gamble: General David Petraeus and the American Military Adventure in Iraq, 2006-2008, New York: Penguin Books, 2009.
}

64 James M. Dubrick, Building Security Forces and Ministerial Capacity, Report I, Best Practices in Counterinsurgency, Washington, D.C.: Institute for the Study of War, August 2009, p. 10.

65 Anthony H. Cordesman and Adam Mausner, Withdrawal from Iraq: Assessing the readiness of Iraqi security forces, Vol. 31, Washington, D.C.: Center for Strategic and International Studies, August 2009, p. 143.

66 Dubrick, 2009, p. 10.

67 Dubrik, 2009, p. 12; Cordesman and Mausner, 2009, p. 143.

68 Dubrik, 2009, p. 12.

69 Richard R. Brennan Jr., Charles P. Ries, Larry Hanauer, Ben Connable, Terrence Kelly, Michael J. McNerney, Stephanie Young, Jason H. Campbell, and K. Scott McMahon, Ending the U.S. War in Iraq: The Final Transition, Operational Maneuver, and Disestablishment of United States Forces-Iraq, Santa Monica, Calif.: RAND Corporation, RR-232-USFI, 2013, p. 42. 
Shortening training before first exposure to combat did have a negative effect on the readiness of the new units, many of which were simply not capable of fighting effectively. ${ }^{70}$ The focus on producing forces that could be thrown into combat as quickly as possible also involved temporarily abandoning plans to transition responsibility for training the Iraqi army to Iraqi forces, under the rationale that only by first stabilizing the security situation in the country could the conditions for a successful transfer of responsibility be created. ${ }^{71}$ This rationale mirrored the overall justification for conducting the "surge" of U.S. forces into Iraq in 2007: that security had to first be established before Iraqis would be able to make progress on political reconciliation. ${ }^{72}$

Evaluations of the U.S.-trained Iraqi units were conducted before they could move on to the next phase of their training or be deployed. These evaluations focused on a range of factors, including basic soldiering skills, whether the unit was properly equipped, had basic logistical capabilities and minimally capable leadership, and were similar to those the U.S. Army conducted for its own units. ${ }^{73}$ An example of the assessment forms used in this evaluation, initially called the Transition Readiness Assessments, and later the Unit Readiness Assessments, is shown in Figure 4.1.

The characteristics assessed were therefore overwhelmingly related to operational skills and the ability of the force to sustain itself logistically. However, it was clear to analysts that many of the greatest problems with Iraqi units, despite their abbreviated training, were not related to any insufficiency in the areas their training did emphasize, but those it did not. A 2005 focus group of Iraqi officers, for example, found that " $[\mathrm{t}]$ he Iraqi military does not understand the Western concept of civil-military relations or the role of the military in a democracy;

\footnotetext{
70 Cordesman and Mausner, 2009, p. 143.

71 Dubrik, 2009, p. 5.

72 See for example: Rend Al-Rahim Francke, Political Progress in Iraq During the Surge, Washington, D.C.: U.S. Institute of Peace, Special Report 196, December, 2007.

73 Brennan Jr. et al., 2013, p. 38.
} 
Figure 4.1

Transition Readiness Report Form for the Iraqi Army

Figure 1: Transition Readinoss Assessment (TRA) Roport Form for the lraqi Army

\section{UNCLASSIFIED}

\begin{tabular}{|c|c|c|c|c|c|c|c|c|c|}
\hline \multirow{2}{*}{ 1. Personnel } & \multicolumn{7}{|c|}{ TRANSITION READINESS ASSESSNENT } & \multicolumn{2}{|l|}{ Besentere } \\
\hline & \multicolumn{4}{|c|}{ OVERLL NSSESSVENT } & \multicolumn{2}{|l|}{ 4. Training } & \multicolumn{3}{|c|}{ OVERALL ASSESSMENT } \\
\hline 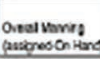 & $\mid$\begin{tabular}{l|}
$\mid$ \\
$\sin \alpha a n$ \\
ranoing
\end{tabular} & 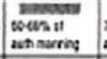 & 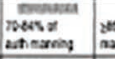 & $\begin{array}{l}\text { exow an } \\
\text { toming }\end{array}$ & \multirow[t]{3}{*}{ vert } & \multirow{3}{*}{ 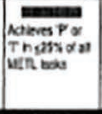 } & \multirow{3}{*}{ 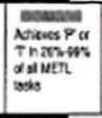 } & \multirow{3}{*}{ 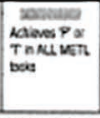 } & \multirow{3}{*}{ 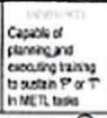 } \\
\hline Gted Narnory & $\begin{array}{l}\csc \alpha \cdot a \\
\text { nuesing }\end{array}$ & \begin{tabular}{|l|} 
6oth at \\
ath nurity
\end{tabular} & $\begin{array}{l}\text { rous d } \\
\text { ath narsing }\end{array}$ & cesd un & & & & & \\
\hline nó Wown & $\begin{array}{l}\csc \alpha=8 \\
\text { ratryg }\end{array}$ & $\begin{array}{l}\text { Wekn di } \\
\text { wh marring }\end{array}$ & $\begin{array}{l}\text { mevos } \\
\text { wath narnog }\end{array}$ & torangh & & & & & \\
\hline \multirow[t]{2}{*}{ Non } & \multirow[t]{2}{*}{ Inste in in } & \multirow[t]{2}{*}{$\begin{array}{l}\text { Par Swion } \\
\text { Eatelchos }\end{array}$} & \multirow{2}{*}{ " } & \multirow{2}{*}{ 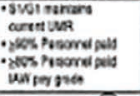 } & $\begin{array}{l}\text { EONWENT } \\
\text { GAHAN? }\end{array}$ & & $\begin{array}{l}1075 \\
\text { Enenas }\end{array}$ & Dreate & smeni \\
\hline & & & & & Wuepess & $\begin{array}{l}\text { iseid } \\
\text { incriston }\end{array}$ & $\begin{array}{l}50 \mathrm{in} \alpha \\
\text { 2ectats }\end{array}$ & $\begin{array}{l}\text { rowes } d \\
\text { anositos }\end{array}$ & $\begin{array}{l}\text { zescid } \\
\text { uereriaton }\end{array}$ \\
\hline \multicolumn{5}{|c|}{ 2. Command \& Control } & \multirow{2}{*}{\multicolumn{2}{|c|}{ 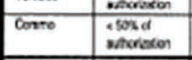 }} & $\begin{array}{l}\operatorname{sem} \alpha \\
\text { sentcitaton }\end{array}$ & $\begin{array}{l}\text { Nowsd } \\
\text { atrotation }\end{array}$ & $\begin{array}{l}\operatorname{los} \text { ut } \\
\text { sutcration }\end{array}$ \\
\hline \multirow{2}{*}{ Hellyerch } & \multirow{3}{*}{ 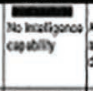 } & \multirow{3}{*}{ 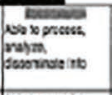 } & \multirow{3}{*}{ 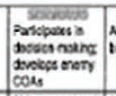 } & \multirow{3}{*}{ 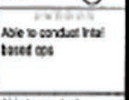 } & & & 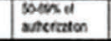 & $\begin{array}{l}\text { Fass di } \\
\text { snoration }\end{array}$ & $\begin{array}{l}\text { inen el } \\
\text { autceaton }\end{array}$ \\
\hline & & & & & 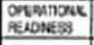 & Danas & manten & Devosat & wentar \\
\hline \multirow{4}{*}{ Grestion } & & & & & Whesen & CFron & soes ach & ravson & 26sson \\
\hline & \multirow{3}{*}{$\begin{array}{l}\text { ho cquniond } \\
\text { contily }\end{array}$} & \multirow{3}{*}{ 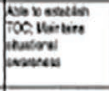 } & \multirow{3}{*}{ 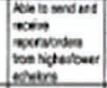 } & Salleninger & Vende: & C50NOA & 5065409 & Tsas on & 260502 \\
\hline & & & & Geaten & Come & $\operatorname{sen} 0 \mathrm{n}$ & seen don & Dasson & $2 \operatorname{tss} 0$ \\
\hline & & & & & 6. Looders: & ship & & ERALL ASSESS & SVET \\
\hline Connelisuices & 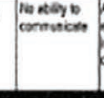 & 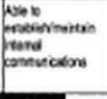 & 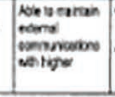 & 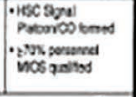 & 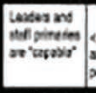 & 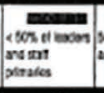 & 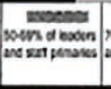 & 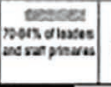 & 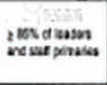 \\
\hline 3. Sustainme & nentlogistic & OVEP & BALL ASSESSU & veIT & Perto & $\mathrm{Ca}$ & ity Asse & ent: & \\
\hline Slody & $\begin{array}{l}\text { Enansion } \\
\text { surdes }\end{array}$ & 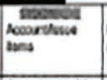 & 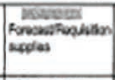 & 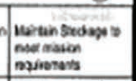 & 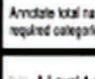 & 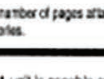 & racted b th ayot. & tSat appaner & adra be \\
\hline & $\begin{array}{l}\text { no Neric: } \\
\text { conousat }\end{array}$ & $\begin{array}{l}\text { Condes PWCS } \\
\text { minsoes }\end{array}$ & 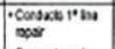 & 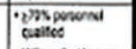 & $\begin{array}{l}\text { Alow } 1 \\
\text { coutatire }\end{array}$ & $\begin{array}{l}\text { I unt in cacul bo of } \\
\text { reugercy operst }\end{array}$ & $\begin{array}{l}\text { oplaring ecos. } \\
\text { sors }\end{array}$ & ateg ard satain & \\
\hline Nenteneros & & enicnort setes & - Patcen mad & 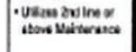 & Altill 2 & $\begin{array}{l}2 \text { unt la capecie of } \\
\text { rempercy cperat: }\end{array}$ & $\begin{array}{l}\alpha \text { praning, ecos } \\
\text { toss wh } \$ f \alpha \text { o }\end{array}$ & $\begin{array}{l}\text { ateg and actani } \\
\text { cosition apsort. }\end{array}$ & \\
\hline & & & 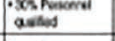 & & & $\begin{array}{l}\text { Sunt ia partalyc } \\
\text { neton vt posito }\end{array}$ & copeble d conde. & atimg wirtatin & gercy ecerations \\
\hline nanapetesten & $\begin{array}{l}\text { Neopine } \\
\text { tsenper } \\
\text { cosbolity }\end{array}$ & 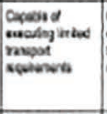 & 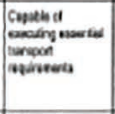 & 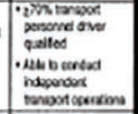 & $\begin{array}{l}\text { Alevel } 4 \\
\text { cotesfons } \\
\text { Tris Unt is } \\
\text { and wil be }\end{array}$ & $\begin{array}{l}4 \text { unt b benno a } \\
\text { s Qurtently As } \\
\text { e ready to ass: }\end{array}$ & $\begin{array}{l}\text { anslor iscacebie of } \\
\text { Assessed at Le } \\
\text { sume IAL in }\end{array}$ & $\begin{array}{l}\text { d coeddating cour } \\
\text { evel }{ }_{\text {morths. }}^{\square}\end{array}$ & margoscy \\
\hline \begin{tabular}{l|l} 
& To \\
mentrater & at
\end{tabular} & $\begin{array}{l}\text { Tonceryy } \\
\text { alinty }\end{array}$ & 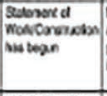 & 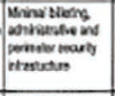 & 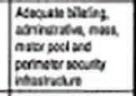 & HSC is ass. & sessed at lev & vel & overal. & \\
\hline Meded & 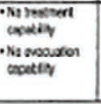 & 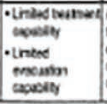 & 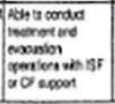 & 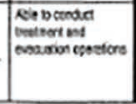 & UNCLAS & SSIFIED & & & \\
\hline
\end{tabular}

sane viut

SOURCE: U.S. Congress, House Committee on Armed Services, Oversight and Investigation Subcommittee, Stand Up and Be Counted: The Continuing Challenge of Building the Iraqi Security Forces, Washington, D.C.: U.S. Government Printing Office, July 2007, p. 168.

RAND RR1832-4.1 
distrusts MOD [the Ministry of Defense] and civilian leadership.”74 Related issues regarding morale and loyalty were endemic:

[The] Coalition training courses have been merely the foundation for the hard work the Iraqis must do to address root issues such as sectarian identity and strife. We have taught thousands to shoot straight and true, but many Iraqis still must decide whom they will shoot at and why. ${ }^{75}$

The United States did take steps to address issues of values and loyalty to the government. ${ }^{76}$ In March 2006, the United States helped to establish the Iraqi Center for Military Values, Principles and Leadership Development. ${ }^{77}$ The center adopted a "train the trainers" approach, with U.S. contractors hired to train Iraqi trainers, who then deployed throughout the Iraqi military to conduct their own training on ethics and accountability to the civilian regime. ${ }^{78}$ The effects of the center appear to have been limited. By 2008, some measure of ethics instruction was incorporated into the basic training course, but given that the course itself was already compact, it is unlikely to have been extensive. ${ }^{79}$

In addition to these concerns regarding the army's values or professionalism, U.S. forces were also cognizant of ethnic and sectarian identity issues and were determined to create a more demographically representative Iraqi army. ${ }^{80}$ However, their success in actually integrat-

\footnotetext{
74 Jack D. Kem and Aaron G. Kirby, "To Change an Army: The Establishment of the Iraqi Center for Military Values, Principles and Leadership," Small Wars Journal, 2009, pp. 4-5.

75 Gary Felicetti, “The Limits of Training in Iraqi Force Development," Parameters, Vol. 36, No. 4, Winter 2006-2007, p. 80.

76 "The campaign plan exhorted the forces to always remember that the 'visible legitimacy and success of the Iraqi Government is the key to mission success"” (Brennan Jr., et al., 2013, p. 35).

77 Brennan Jr. et al., 2013, pp. 5-6.

78 Brennan Jr. et al., 2013, p. 6.

79 U.S. Department of Defense, Measuring Stability and Security in Iraq: Report to Congress in Accordance with the Department of Defense Supplemental Appropriations Act 2008, Washington, D.C., December 2008.

80 Bensahel et al., 2008, p. 142.
} 
ing disparate groups within the army or cementing any loyalty to the emerging Iraqi regime was limited:

Ethnic tensions divide Iraq, and they divide the new army. "Thinking that we could go in and produce a unified Iraqi army is like thinking you could go into the South after the Civil War and create an army of blacks and whites fighting side by side," Robert Pape, of the University of Chicago, told me. "You can pay people to go through basic training and take moderate risks. But unless they're really loyal to a government, as the risks go up, they will run." Almost every study of the new Iraqi military raises doubts about how loyally "Iraqi" it is, as opposed to Kurdish, Shiite, or Sunni. ${ }^{81}$

The United States did make strong efforts to create integrated army units, and the overall ethnic and sectarian mix of the Iraqi army by 2008 did roughly reflect the demographic makeup of the country. ${ }^{82}$ For more senior positions in the army, however, there were feelings that Shiites received preferential treatment. ${ }^{83}$ Furthermore, the attempt to create demographically balanced forces was not applied to Iraqi National Guard units, which were typically formed from specific geographic regions and therefore tended to be more homogeneous. ${ }^{84}$ However, many of these units were later merged into the Iraqi army without being significantly altered. ${ }^{85}$ These issues became exacerbated further after the withdrawal of U.S. forces, as will be discussed.

\footnotetext{
81 Fallows, 2005, p. 74.

82 Cordesman and Mausner, 2009, p. 121.

83 Cordesman and Mausner, 2009, p. 122. Even notwithstanding Maliki's efforts to personalize loyalty in the officer corps, discussed in greater detail in this chapter, feelings of unfairness in promotion may also have been a result of the fact that the pre-2003 officer corps, many of whom returned to the new Iraqi army, was disproportionately Sunni, and that efforts to make the senior officers more representative would therefore necessarily prioritize the promotion of Shia officers. See Florence Gaub, Rebuilding Armed Forces: Learning from Iraq and Lebanon, Carlisle, Pa.: U.S. Army War College, Strategic Studies Institute, 2011.

${ }^{84}$ U.S. Congress, 2007.

85 U.S. Congress, 2007, p. 97.
} 
In addition to these efforts to address issues of identity in the training or composition of the Iraqi army, the United States also made significant efforts to minimize the effects of the divisions within that force in practice. This included working directly to build partnerships between armed forces with different ethnic or sectarian backgrounds, such as the Golden Lions in Kirkuk. ${ }^{86}$ It also included numerous macro and micro efforts to mediate identity disputes involving Iraqi security forces:

\begin{abstract}
Perhaps more important, U.S. forces served as an impartial "honest broker" to encourage their Iraqi counterparts to pursue their mission in a manner that did not exacerbate ethnic, sectarian, or regional disputes. This mediation role of the U.S. military was embraced by the sergeant and lieutenant at the proverbial "pointy end of the spear," as well as by General Austin, who often mediated high-level disputes that had the potential to flare into broader conflict. ${ }^{87}$
\end{abstract}

The importance of such a role for U.S. forces, however, highlights the potential dangers of sectarianism once the "honest broker" had withdrawn from the scene.

Despite these issues, the Iraqi army remained an institution that was trusted by the majority of the population of Iraq. In a November 2009 survey, 85 percent of the population were confident that the Iraqi army would protect them, the highest rating of any institution in the country and notably higher than the degree of confidence expressed in U.S. forces. ${ }^{88}$ The United States funded one innovative attempt to fur-

\footnotetext{
86 The Golden Lions were a battalion-sized joint partnership between Iraqi, U.S., and Kurdish security forces that patrolled and operated together. While an interesting proof of concept, few Iraqi security forces operated in such a manner. U.S. Congress, 2007, p. 97.

87 Brennan Jr. et al., 2013, p. 144.

88 DoD, Measuring Stability and Security in Iraq: Report to Congress in Accordance with the Department of Defense Supplemental Appropriations Act 2008, Washington, D.C., December 2009.
} 
ther increase positive popular identification with the Iraqi military: a series of comic books, a scene from which can be seen in Figure 4.2. ${ }^{89}$ The comics, of which there were at least two series that received limited distribution in Iraq, show heroic cross-sectarian Iraqi military and police forces tasked with fighting terrorists. The publication also addresses such themes as religious tolerance and the identification of Islam with the nation of Iraq..$^{90}$ The number of these comics actually distributed in Iraq is unclear, although initial plans called for printings of individual issues in the tens of thousands..$^{91}$ Ideally, such efforts should come from within host-nation forces, but they offer an example of the sort of propaganda that can be at least facilitated by the United States.

\section{After the U.S. Withdrawal: Sectarianism as a Means to Authoritarianism}

Following the withdrawal of U.S. forces from Iraq, the Iraqi government under Nouri al-Maliki began to adopt increasingly authoritarian policies to consolidate its control over the Iraqi security forces. Maliki implemented numerous changes designed to "coup-proof" the military and ensure its personal loyalty to him..$^{92}$ In 2007, he created the Office of the Commander in Chief (OCINC), which issued orders directly to units, bypassing the chain of command and the Ministry of Defense. ${ }^{93}$ Maliki purged the officer corps of those that he considered to be poten-

\footnotetext{
89 Sharon Weinberger, "Iraq's Latest Psychological Operation: Comic Books (Updated)," WIRED, February 19, 2008.

90 RAND translation of two comics: The Hawk, Iraq Justice and Peace (Al-Saqur, 'Iraq al-'Adala wa al-Salam), Vol. 1, 2005; Team Six, Two Rivers for Developed Publications (AlFirqa al-Sadisa, Al-Rafidayn Lil-Matbu'at al-Matura), Vol. 2, 2005.

91 Herbert A. Friedman, “Operation Iraqi Freedom,” Psywarrior.com, undated.

92 As one of Maliki's domestic political opponents noted: "Haidar Al-Mullah, a Shiite representative from Ayad Allawi's Iraqiyya party expressed concern about the politicization of the ISF [Iraqi Security Forces], saying 'Maliki considers the Iraqi security forces' ability to protect the government, and not the country, as the deciding factor'" (Brennan Jr. et al., 2013, p. 174).

93 Marisa Sullivan, Maliki's Authoritarian Regime, Washington, D.C.: Institute for the Study of War, April 2013.
} 
Figure 4.2

Image from The Hawk, Iraq Justice and Peace Comic Book

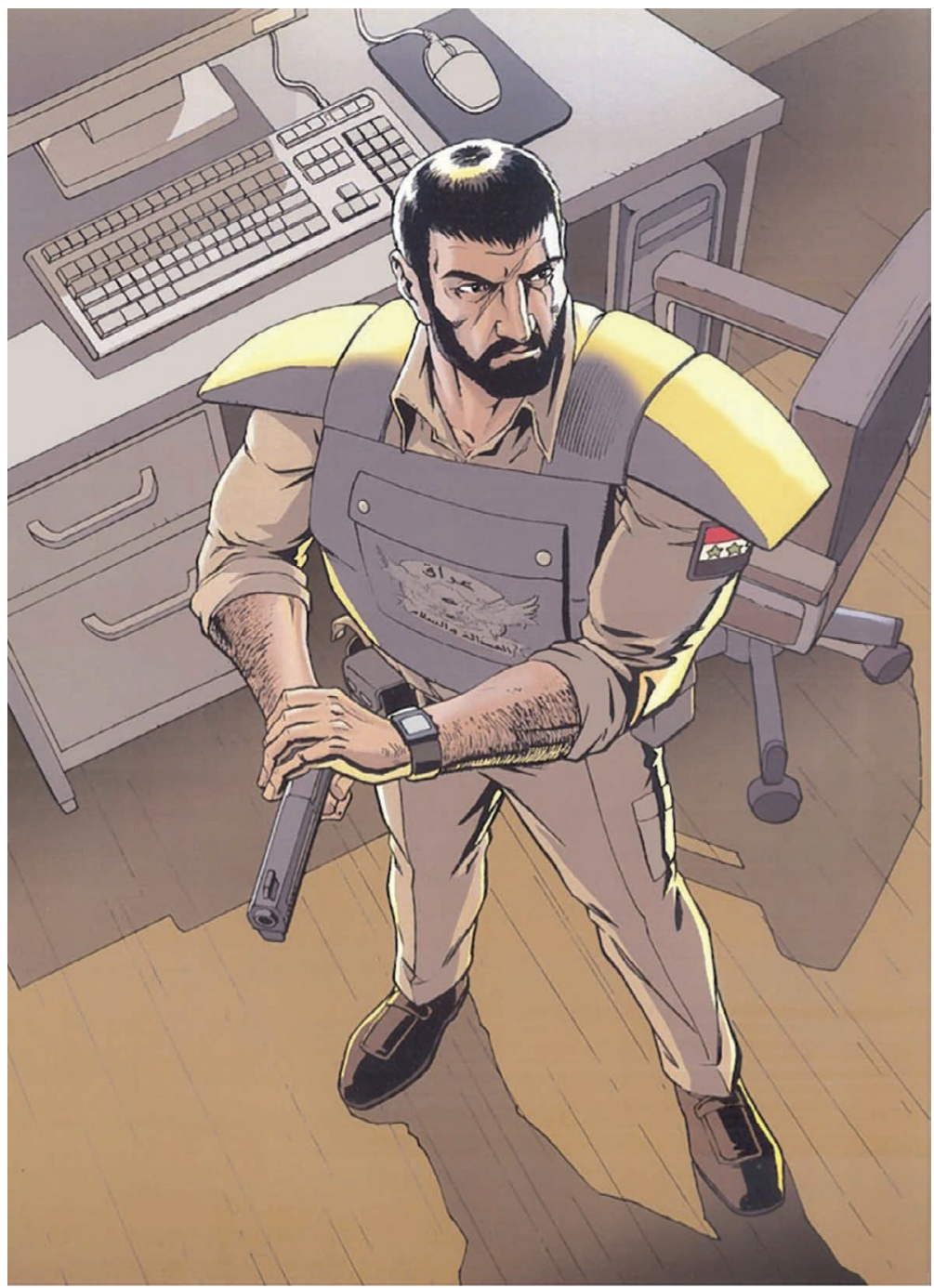

SOURCE: The Hawk, Iraq Justice and Peace (Al-Saqur, 'Iraq al-'Adala wa al-Salam), Vol. 1, 2005.

RAND RR1832-4.2 
tially disloyal or even merely apolitical. ${ }^{94}$ The result was to create an army, in particular one stationed near the capital, that was personally loyal to the prime minister and whose senior officers were dominated by Shia. ${ }^{95}$ Once under his control, Maliki issued orders through OCINC to elite units to conduct raids against rival politicians, most notably the Sunni vice president, Tariq al-Hashemi, to consolidate his control over the government as a whole. ${ }^{96}$ The moves were particularly focused on removing senior Sunni politicians. ${ }^{97}$ The politicization of the Iraqi special operations forces became a particular concern. ${ }^{98}$ Maliki also installed political commissars, or dimaj, directly into military units to monitor and report on their political orientation and leanings. ${ }^{99}$ As Rayburn noted:

By 2011, the prime minister's office had established an independent network of officers embedded in several Iraqi Army commands known as the Office of Security and Information, considered by some local officers to be "commissars" means to gather information on the army rather than on enemy threats. This system of control was familiar to Iraqi officers, since it resembled the working of the Presidential Diwan under Saddam Hussein. ${ }^{100}$

The result of these changes was a military that was unlikely to be a threat to Maliki's regime, if indeed it ever was, but also one that abandoned any progress it made toward being apolitical or toward establish-

\footnotetext{
94 Noah Pollack, "Iraq Military Situation Report," Up Front blog (brookings.edu), June 14, 2014.

95 Joshua Partlow, "Maliki's Office Is Seen Behind Purge in Forces," Washington Post, April 30, 2007; Joel Rayburn, Iraq After America: Strongmen, Sectarians, Resistance, Stanford, Calif.: Hoover Institution Press, 2014.

96 Sullivan, 2013, pp. 11-12; Rayburn, 2014, pp. 234-235.

97 Adnan Duraid and Tim Arango, "Arrest of a Sunni Minister's Bodyguards Prompts Protests in Iraq," New York Times, December 21, 2012.

98 Brennan Jr. et al., 2013, p. 188.

99 “Why Iraq's Army Crumbled," The Economist, June 21, 2014.

${ }^{100}$ Rayburn, 2014, p. 56.
} 
ing loyalties that were institutional rather than personalized. ${ }^{101}$ While personal loyalty to Maliki was paramount, and the army retained some prominent Sunni commanders, in practice Maliki's consolidation of power and persecution of several prominent Sunni politicians exacerbated sectarian divisions in the country. Sunni Arabs began to increasingly view the Iraqi security forces with suspicion and report instances of abuse. ${ }^{102}$

The role of an additional external actor-Iran-deserves particular consideration here. Since 2003, Iran has actively funded and sometimes directed the activities of several Shia militias in Iraq. ${ }^{103}$ Members of these militias thoroughly penetrated the emerging Iraqi security services in the early years of the U.S. occupation, undermining attempts to build unit cohesion and cement the loyalty of these services to the Iraqi state. ${ }^{104}$ Since the U.S. withdrawal, the prevalence of Shia militias with ties to Iran has only grown, and their power and influence in many areas is often greater than official institutions such as the Iraqi army. ${ }^{105}$ These militias often have close ties to the Iraqi security services and operate with virtual impunity, committing abuses-particularly against Sunnis - that have greatly exacerbated sectarian tensions. ${ }^{106}$ While Maliki was generally considered to pursue his own interests, he did receive significant political and financial support from Iran, limiting his incentives to take steps to curtail Iranian-directed Shia mili-

101 The poor state of Iraqi training institutions, sidelined in favor of U.S.-centric approaches during the surge, also contributed to the relative ease and speed with which Maliki was able to undermine the professionalism of the force. Brennan Jr. et al., 2013, pp. 201-202.

102 International Crisis Group, 2013, pp. 5-10; Al-Qarawee, 2014, p. 17.

103 DoD, 2009, p. v.

${ }^{104}$ Lionel Beehner, Shiite Militias and Iraq's Security Forces, Washington, D.C.: Council on Foreign Relations, November 30, 2005; interview with former senior advisor to U.S. forces in Iraq, March 2015.

105 Phillip Smyth, “All the Ayatollah’s Men,” Foreign Policy, September 18, 2014.

106 Jessica Lewis, Ahmed Ali, and Kimberly Kagan, Iraq's Sectarian Crisis Reignites as Shi'a Militias Execute Civilians and Remobilize, Washington, D.C.: Institute for the Study of War, May 31, 2013. 
tias. ${ }^{107}$ The failure to do so further undermined the development and reputation of the Iraqi security forces, including the army.

The Iraqi army, and particularly its units stationed in Sunni areas, quickly lost much of its cohesion and effectiveness. In summer 2014, the Islamic State launched an offensive into western Iraq, and a small force of roughly 10,000 fighters quickly seized Mosul and many other Sunni-majority areas in western Iraq. ${ }^{108}$ The Iraqi army's 2nd Division, stationed in Mosul, performed poorly, with many soldiers abandoning their posts, many of which fell to the Islamic State without a shot fired. ${ }^{109}$ Numerous factors contributed to this failure, including poor training and corrupt leadership, but the collapse of the Iraqi army in this area also highlighted a total breakdown in trust between the local Sunni population and the Iraqi state. ${ }^{110}$ Concerned about increasing collaboration between sectarian Shia militias and the Iraqi army, the local Sunni population grew increasingly alienated from the army, and as the Islamic State advanced, few believed that Iraqi forces would protect the local population. ${ }^{111}$ As a result, Sunni soldiers were often among the first to desert their posts in Mosul, fearful that the Islamic State would retaliate against their families if they fought and doubtful that Iraqi forces would do anything to prevent it. ${ }^{112}$ Maliki's use of the security forces as a tool to ensure his own hold on power had both hollowed out the force of much of its effective leadership and divorced it from the population it was originally meant to protect, particularly in Sunni areas.

The resulting crisis led to Maliki's resignation under pressure from Shia politicians, Iran, and the United States, and the installation of a

107 Brennan Jr. et al., 2013, pp. 301-302.

${ }^{108}$ Martin Chulov, Fazel Hawramy, and Spencer Ackerman, "Iraq Army Capitulates to ISIS Militants in Four Cities," Guardian, June 11, 2014.

109 International Crisis Group, Iraq's Jihadi Jack-in-the-Box, Beirut and Brussels, June 20, 2014; Yasir Abbas and Dan Trombly, "Inside the Collapse of the Iraqi Army's 2nd Division," War on the Rocks, July 1, 2014.

110 Abbas and Trombly, 2014.

111 Abbas and Trombly, 2014.

112 Abbas and Trombly, 2014. 
less-divisive figure in Haider al-Abadi. ${ }^{113}$ Abadi pledged to pursue reconciliation with both Sunni and Kurdish groups and has taken some steps to reverse the polarization of the country under Maliki. ${ }^{114}$ With a new government in place, the United States restarted military and security cooperation with Iraq to combat the Islamic State, including the deployment of roughly 3,000 U.S. troops, divided between those who are advising and assisting Iraqi combat units and those who are dedicated to training. ${ }^{15}$ The training currently consists of a six-week course covering tactical and operational topics such as urban warfare as well as leadership and ethics issues and is intended to train 10,000 Iraqi troops that can then form the core of a counterattack to reclaim territory from the Islamic State. ${ }^{116}$ The units being trained for this advance through predominantly Sunni territory consist primarily of Shias from southern Iraq. ${ }^{117}$

It is too early to assess whether Abadi's attempts to reverse the polarization of the Iraqi state and army will be successful. ${ }^{118}$ The early signs, however, are not promising:

The growing tendency in Baghdad and the south to equate Shiite militias with the national army, to declare oneself a patriot while expressing gratitude to Iran for its intervention, and to subsume national symbols under Shiite ones ... is reshaping Iraqis'

113 Matt Bradley, “Iraq Crisis: Nouri al-Maliki Quits,” Wall Street Journal, August 15, 2014.

114 Muhamed H. Almaliky, "Mending Iraq: Can Abadi Bridge the Country's Sectarian Divide?” Foreign Affairs, January 16, 2015.

115 Helene Cooper and Michael D. Shear, "Obama to Send 1,500 More Troops to Assist Iraq," New York Times, November 7, 2014; John Redfield, "Coalition Assists in Training Thousands of Iraqi Soldiers," U.S. Central Command Public Affairs, MacDill Air Force Base, Fla., March 31, 2015.

116 Michelle Tan, "Inside the Iraq Mission: What Our Troops Are Doing," Army Times, April 2, 2015.

117 Tim Arango, "U.S. Troops, Back in Iraq, Train a Force to Fight ISIS," New York Times, December 31, $2014 b$.

118 Almaliky, 2015. 
national identity in ways that will vastly complicate well-intentioned efforts to advance inclusive politics and governance. ${ }^{119}$

One area where attempts at reconciliation are particularly noteworthy for this report is the struggle over symbols of national identity, such as the Iraqi flag. While the relative importance of such symbols can be debated, they do reflect the difficulty that post-2003 Iraq has had in coming to terms with both its past and its present identity. Iraq has changed its flag several times since 2003, including a disastrous U.S.-organized attempt that was deemed to resemble the Israeli flag, as well as changes to minimize symbolic references to the period of Ba'athist rule. ${ }^{120}$ Under Maliki's rule, the national flag was increasingly replaced by a Shiite-specific flag within the army, and attempts under Abadi to reverse the trend have thus far met with little success. ${ }^{121}$

\section{Conclusion}

U.S. efforts to build an Iraqi army that would help stabilize the country and support its regime were fatally undermined by unresolved tensions between Iraq's major ethnic and sectarian groups. While the roots of these tensions certainly predated the U.S. invasion, U.S. policies since 2003 also helped to exacerbate them. ${ }^{122}$ The United States did take limited steps both to promote an Iraqi sense of identity and to pressure the major ethnic and sectarian groups to reach a political understanding. However, in the face of a violent widespread insurgency, the United States was focused on providing security, combating this insur-

119 International Crisis Group, Defeating the Iraqi State, One Victory at a Time, March 26, 2015.

${ }^{120}$ Abeer Mohammed and Solomon Moore, "Iraq Parliament Purges Hussein Vestiges on Flag," New York Times, January 23, 2008.

121 Tim Arango, “In Struggle for National Identity, Iraqis Rally Around Many Flags,” New York Times, December 22, 2014 a.

122 See for example, Joel Wing, "A Critical Look At Iraqi Nationalism and Sectarianism, an Interview with Author Harith Hasan al-Qarawee," musingsoniraq.blogspot.com, February 14, 2014. 
gency, and training the Iraqi army as quickly as possible so that it could join the fight. Promoting reconciliation and national identity were U.S. goals, but they were pursued either in parallel or secondarily to the overriding objective of providing security.

The operating theory of the 2007 U.S. surge, for example, was that security had to be provided to allow space for political accommodation. ${ }^{123}$ While this policy was effective in reducing levels of violence in Iraq, the political progress never materialized. ${ }^{124}$ Indeed, parts of the U.S. strategy, such as relying on tribal forces to combat the insurgency, may have worked against efforts to build the Iraqi state and promote a single national identity. ${ }^{125}$ The focus on security during this period also helped created the conditions for Maliki to erode the autonomy of the Iraqi army. As Sullivan notes: "the security exigencies and new security bodies created during the surge period gave Maliki greater latitude to assert government control of security in Iraq and consolidate his own control over Iraq's security apparatus." 126 Within a few short years, the Iraqi army had been effectively reduced to a status similar to what it held under Saddam: an instrument of patronage and protection for the regime.

It is worth noting that after the fall of Mosul in 2014, the United States effectively reversed the equation, demanding political progressnamely the resignation of Maliki—before it agreed to provide greater

123 As President George W. Bush argued, "reducing the violence in Baghdad will help make reconciliation possible." See Transcript of President Bush's Address to Nation on U.S. Policy in Iraq, New York Times, January 11, 2007.

124 The United States did attempt to promote political reconciliation simultaneous to the surge in U.S. forces. However, it was clear that this surge was not conditional on political progress, giving the United States little leverage over Maliki and other actors. See Steven Simon, "The Price of the Surge: How U.S. Strategy Is Hastening Iraq's Demise," Foreign Affairs, Vol. 87, No. 3, May/June 2008; Jessica T. Matthews, "The Surge Has Failed in Its Objective," Carnegie Endowment for International Peace Policy Outlook, September 2007.

125 Austin Long, “The Anbar Awakening," Survival, Vol. 50, No. 2, April 2008. After U.S. forces withdrew, efforts to integrate Sunni tribal forces—-such as the Sons of Iraq-into the Iraqi Army were "slow and uneven" (Brennan Jr. et al., 2013, p. 57).

126 Sullivan, 2013, p. 10. 
levels of SA. ${ }^{127}$ This demand-echoed by other actors including, notably, Iran-was successful in removing Maliki and leading to the installation of a figure apparently more committed to a cross-sectarian Iraqi identity in Abadi. ${ }^{128}$ Whether the new government will be able or willing to reverse the damage done to such key institutions as the army, however, remains uncertain.

Despite these difficulties, Iraqis do retain a sense of national identity that is not rooted in their ethnic or sectarian identities. ${ }^{129}$ The attempts throughout the years by the monarchy, military dictatorships, and the Ba'ath party to create and sustain such an identity have had an effect, particularly among the Arab population, and are one of the reasons why the country remains unlikely to splinter. However, other, more localized identities such as ethnicity, sect, and tribe are now stronger, and political entrepreneurs have ample opportunity to draw on the resulting divisions to acquire and expand their power.

Although Iraq is very different than Vietnam, there are parallels with respect to two things. One is the failure of the host nation's leadership to provide the vision and effective leadership with respect to building the nation and promoting narratives of the nation that support the war aims. In Vietnam, Diem had some ideas and did some things well, but he did not go far enough and was relatively ineffective, at least when compared with his successors. Post-2003, Iraq's leadership, however, presents a far more dismal record. The other is the relative inattention by the United States to the failures of the host-nation leadership and the need in both cases to build républicain armies. In both cases, the United States ended up focusing on force structure and other quantitative metrics.

In both cases, the question that remains is whether there was anything the United States could have done (or could still do, in Iraq's case) to alter the situation, absent more vigorous and effective host-nation

\footnotetext{
127 Loveday Morris and Karen DeYoung, "Maliki Steps Aside, Easing Iraq’s Political Crisis," Washington Post, August 14, 2014.

128 Ali Hashem, "How Haider al-Abadi became Iraq's next prime minister," Al-Monitor, August 24, 2014.

${ }^{129}$ Fanar Haddad, “Why Arab Iraq Survives," Foreign Policy, November 7, 2013.
} 
leadership. The Korean example suggests that it is possible to encourage and inform evolving nationalist ideologies and inculcate at least among military officers certain ideas. Korea, of course, had remarkably effective nation-builders (Rhee and Park), who almost certainly deserve most of the credit for their country's success. Even if there was little the United States could have done in Vietnam or Iraq, attention to the real requirements of nation-building and the need to create armies that promoted ideologies that legitimized political regimes arguably would have provided U.S. advisors, analysts, and policymakers with a more accurate understanding of the situation and the effectiveness of U.S. policy. One is less likely to fixate on force structure, for example, if one understands how little it matters compared with factors that are likely to induce what force there is to stand and fight. MACV and policymakers, it should be remembered, shared the belief that, if the United States provided enough resources and the ARVN reached a certain shape and size, victory would be assured. MACV was able to provide metrics that gave policymakers reason for cautious optimism.

In the Iraqi case, one might have understood better the difficulty of forging a coherent and motivated Iraqi national force. One might not have been surprised by the eventual cooption and ineffectiveness of the institution it spent so much to build and adjusted its policies accordingly. 



\section{The Ghanaian Army}

\section{Introduction}

In 1957, Ghana became the first of Britain's African colonies to gain independence. Ghana from the beginning was fortunate to have leaders with a vision of the nation that involved unifying the country's ethnically, linguistically, and religiously diverse population by replacing particular identities with a national Ghanaian one. They also envisioned the army playing an important role in the nation-building project. For a variety of reasons, however, among them ineffective leadership, Ghana struggled to realize its founders' ambitions. Its army, for example, has repeatedly overthrown civilian governments. Nonetheless, Ghana has achieved a remarkable degree of stability since its democratic transition in 1992, with its army increasingly displaying all the hallmarks of a force in tune with the requirements of nation-building and promoting the values and legitimacy of the Ghanaian republic. Ghana, moreover, represents a case in which the army's civic or républicain qualities are of greater importance than its operational capabilities. The country has not faced significant external or internal security threats, and what has mattered most for the Ghanaian army is not its operational effectiveness but its political comportment and its efforts to promote Ghanaian civic values. It can even be argued that the Ghanaian army's greatest contribution to the nation's security is its good behavior.

This chapter examines the Ghanaian army's role in the country's nation-building and political development, looking at its assigned role in the larger context of Ghanaian nation-building, then its mixed 
record during the country's first decades, and, finally, the army in post1992 Ghana.

\section{Inventing Ghana}

When the Gold Coast colony gained independence from the United Kingdom in 1957 and became the sovereign nation of Ghana, it suffered from many of the weaknesses typical of former colonies but also displayed an unusual number of strengths. As for the weaknesses, chief among them was the country's great ethnic, linguistic, and religious diversity. Ghana boasts approximately 50 mutually unintelligible languages and multiple dialects of those, although most Ghanaians fall into one of three ethnolinguistic families: the Akan/Ashanti (47.5 percent, according to the Central Intelligence Agency [CIA] World Factbook) in central Ghana ${ }^{1}$; the Mole-Dagbon (16.6 percent) in northern Ghana; and the Ewe (13.9 percent) in southeastern Ghana. ${ }^{2}$ Many northerners, moreover, are Muslim, with the estimated Muslim population at 17.6 percent, according to the CIA World Factbook.

Yet Ghana had an even more impressive set of strengths. The country benefited in the outset from a relatively large number of Westerneducated citizens, many with real administrative skills, as well as an elite with a relatively well-developed sense of national identity, which was heavily influenced by pan-Africanism. What this meant for Ghana was that its leadership-foremost among them Kwame Nkrumah (1951-1966), who served as the Gold Coast's highest administrator before assuming the presidency of Ghana-hit the ground running with a clear nation-building mission that included cultivating a Ghanaian national identity and using the tools of the state, including the military, explicitly to promote that identity at the expense of particularisms. One strong and weak feature, depending on one's perspective,

\footnotetext{
1 CIA, “The World Factbook: Ghana," cia.gov, January 12, 2017a.

2 Akosua Anyidoho and M. E. Kropp Dakubu, "Ghana: Indigenous Languages, English, and an Emerging National Identity," in Andrew Simpson, ed., Language and National Identity in Africa, Oxford: Oxford University Press, 2008, p. 142.
} 
is that precolonial Ghana was a relatively well-developed state dominated by the Ashanti ethnic group and their allies whose borders corresponded with present-day Ghana's. Thus there is, at Ghana's core, a pre-existing identity and tradition of governance. The catch, of course, is that not all Ghanaians are Ashanti or their allies, and balancing power among the country's different groups has remained a challenge despite the progress of a single Ghanaian identity.

Nkrumah's nation-building zeal exacerbated some basic cleavages in Ghanaian politics that would have enduring legacies. He represented a centralization drive, a bid to create a strong central government that promoted a unitary national identity, at the expense of ethnic, geographic, and tribal interests. For example, he was opposed to the kind of federalism that won the day in Nigeria, and he wanted to mobilize all of Ghana behind the leadership of a single party intent on making a particular vision of the nation. He also favored socialist economics and development theories, including forced industrialization. Against Nkrumah were more conservative forces that preferred federalism or at least giving greater political weight to ethnic, tribal, or regional interests. They also tended to favor more liberal economics. ${ }^{3}$ The leader of Ghana's "right wing" in the earlier decades was Kofi Busia, who succeeded Nkrumah following the 1966 coup.

\section{Detribalization of the Military}

Nkrumah had clear plans for the military, which he wanted to turn into a national force that was both African (i.e., with an indigenous officer corps, rather than British officers) and "national," meaning it would better reflect the country's demographics while also transcending ethnicity and fostering inside the force and outside it a new concept of citizenship and national identity.

Because of British recruiting policies, Ghana's colonial-era military was ethnically out of balance. Most soldiers, particularly unskilled ones, came from the north, while the relatively few non-British officers were predominantly from the better-educated coastal populations, in

3 Björn Hettne, "Soldiers and Politics: The Case of Ghana," Journal of Peace Research, Vol. 17, No. 2, June 1980, pp. 176-177. 
particular the Ga, Ewe, and Fante. ${ }^{4}$ Ghana's precolonial overlords, the Ashante of the central part of the country, were nearly absent, in part because the original purpose of the colonial force was to help the British subjugate the Ashanti. ${ }^{5}$

Nkrumah had several competing priorities. He wanted to make sure the army was politically safe, while at the same time he wanted to reduce the force's reliance on British officers. He also wanted to redress the ethnic imbalances and begin the process of making ethnicity irrelevant. His goal was to "detribalize" the army as part of the larger effort of detribalizing all of Ghanaian society. To use his parlance, he wanted to "individual-nationalize" the country along the classic Western post1789 model of leveling society so that everyone is an individual citizen dealing with the state on equal terms:

[w]e insist that in Ghana in the higher reaches of our national life, there should be no reference to Fantis, Ashantis, Ewes, Gas, Dagombas, "strangers," and so forth, but that we should call ourselves Ghanaians - all brothers and sisters, members of the same community— the state of Ghana. ${ }^{6}$

Nkrumah explicitly conceived of the army as playing an integral role in Ghanaian society, alongside a national political party (in this case, the Convention People's Party [CPP]), civil-society organizations, trade unions, patriotic groups, youth and women's associations, schools, and the mobilization of myths, symbols, and traditions, some of them new. ${ }^{7}$

During Ghana's first postcolonial years, Nkrumah made progress with regard to the army's ethnic mix, namely by reducing the northern preponderance in the force and raising the representation of previously

4 J. 'Bayo Adekson, "Army in a Multi-Ethnic Society: The Case of Nkrumah's Ghana, 1957-1966," Armed Forces and Society, Vol. 2, No. 2, 1976, p. 253.

5 Hettne, 1980, p. 174.

6 Adekson, 1976, p. 255.

7 Adekson, 1976, p. 257. 
under- or nonrepresented groups, among them the Ashanti. ${ }^{8}$ Within the officer corps, he similarly managed to reduce the preponderance of Ga and Ewe. ${ }^{9}$ Adekson observes that he was able to do this without resorting to quotas or freezing promotions, namely by growing the force while simply opening up recruitment. ${ }^{10} \mathrm{He}$ also "deconcentrated" the military to spread its presence around the country (and extend the presence of the central government) while at the same time mitigating the political risk associated with concentrating too much power in one place. ${ }^{11}$

Nkrumah initiated political indoctrination both within the military and in Ghanaian society as a whole, where he hoped to use the military and a variety of paramilitary or military-influenced or controlled civic organizations such as trade unions, youth movements, and women's organizations to promote his ideas. He wanted to foster a "militantly nationalistic, supra-ethnic culture" and various civic virtues such as discipline and self-abnegation through a variety of training programs. ${ }^{12}$ He also had the army engage in "socio-political functions" through various infrastructure and other projects around the country to further engender support throughout the population. ${ }^{13}$ The overall intent here was to "lead to one useful result-discipline. The whole nation from the President downwards will form one regiment of disciplined citizens." 14

Even as of 2015, there are recruitment policies to help ensure representation from across Ghana. The numbers are not advertised, but several army leaders confirmed a policy of regional inclusion, where recruitment aims to build the army with population-based geographic

\footnotetext{
8 Adekson, 1976, p. 258.

9 Adekson, 1976, p. 259.

10 Adekson, 1976, p. 259.

11 Adekson, 1976, p. 259.

12 Adekson, 1976, p. 261.

13 Adekson, 1976, p. 261.

14 Adekson, 1976, p. 262.
} 
representation throughout Ghana. ${ }^{15}$ Those leaders specifically noted the lack of tribal quotas, although geography is at times a good indicator of such an affiliation. Those leaders interviewed in this report identified this policy as important to the army's identity and its stability. Jobs in the military are desirable by many (more on this later in the chapter), and there is ample competition for those jobs and thus heightened standards for accession. Ensuring that those positions are not seen as overly bestowed on one group over another helps with stability and perceptions.

\section{Falling Back to Earth}

Despite Nkrumah's intentions and his best efforts, his successes were only partial for a variety of reasons. Of relevance to this report are two areas that proved to be stubbornly problematic: ethnic strife and military intervention in politics. With regard to ethnic matters, Nkrumah in the last few years of his regime adopted a more pragmatic approach largely for the sake of political survival, namely by prioritizing political expediency ahead of idealism. His idealism would never go away, but neither he nor any of his successors could escape practical realities or even their own parochialisms. Indeed, toward the end of Nkrumah's rule, there was a resurgence of tribalism as intertribal relations polarized, and leaders from different ethnic groups accused one another of tribalism. It would clearly take a lot longer than Nkrumah originally hoped to inspire Ghanaians to stop thinking in terms of a zerosum competition among ethnic groups and to redefine themselves in terms of Ghanaian national identity. Two years after being rejected from office, Nkrumah reflected that while he believed Ghanaians had "largely eliminated tribalism as an active force, its by-products and those of the family system were still with us." $16 \mathrm{He}$ admitted to being unable to choose ministers, for example, "without some regard to tribal origins," and even in the party, "there was at times a tendency to

\footnotetext{
15 Author interview with two army leaders, July 10, 2015.

16 Adekson, 1976, p. 267.
} 
condemn or recommend some individual on the basis of his tribal or family origin." 17

Ultimately, according to Adekson, Nkrumah contributed to the persistence of tribalism by juggling ethnic groups and divide-and-rule tactics combined with increasingly authoritarian practices. ${ }^{18}$ Indeed, Hettne argues that, despite or perhaps because of Nkrumah's detribalization efforts, tribal solidarity played a clear role, "and the politics of ethnicity was also to dominate subsequent events." 19 The new transitional government, the National Liberation Council (NLC), attempted to apply the more conservative approach of Nkrumah's rival, Kofi Abrefa Busia, who espoused a more moderate approach to modernize Ghanaian society and favored working in consultation with the nation's different authorities, including tribal ones. The NLC government nonetheless remained riven by cleavages and fell out along ethnic lines to the point that the ethnic tensions undermined the NLC's popularity and hastened the transition to a civilian government. ${ }^{20}$ They would remain a driver of instability, with the country's different political factions and political parties ultimately aligning according to ethnic group. Busia's Progress Party, for example, in 1969 received 78 percent of its votes from Ashanti, compared with 18 percent from the Ewe. ${ }^{21}$ The new opposition party, the National Alliance of Liberals, boasted the reverse proportions: It drew 17 percent of its support from Ashanti, compared with 77 percent from the Ewe. ${ }^{22}$ Similarly, ethnic factors also played a role in the 1972 military coup against Busia, which, among other things, can be understood as an effort by Ewe officers to correct a relative decline under Busia. ${ }^{23}$ Indeed, in nearly all of Ghana's regime

\footnotetext{
17 Adekson, 1976, p. 267.

18 Adekson, 1976, p. 267.

19 Hettne, 1980, p. 179.

20 Hettne, 1980, p. 80.

21 Hettne, 1980, p. 80.

22 Hettne, 1980, p. 80.

23 Hettne, 1980, pp. 181-182.
} 
changes (see Table 5.1, with military coups d'état in bold), there was at least an ethnic subtext.

\section{Politicization of the Military}

The Ghanaian army took it upon itself to protect the nation-building project by intervening in politics and "correcting" the course steered by civilian leaders. This points to one of the dangers involved in creating a military imbued with nationalist ideology and a positive estimation of its own role in the nation-building project: There is a real risk that the military will seek power for itself. Generally speaking, the military officers involved in Ghana's coups acted out of a combination of self-interest and sincere conviction. Often they acted to advance the interests of particular ethnic groups, which they may have identified with the common good. It also points to another problem, which is that military interventions in politics are not intrinsically or completely negative events. Much depends on the context as well as the comportment and objectives of those involved, although clearly the risk of doing real harm to a nation's political development is great.

For example, the military officers leading the 1966 coup called themselves "liberators," and, according to some scholars, the population viewed them as such. Thus crowds gathered to celebrate as the soldiers and officers ousted Nkrumah's CPP from office; the military saw no need for a curfew. Ghana scholars claim that the rapid success of the army in this period reflected the failures of Nkrumah's government, which eclipsed in the collective memory his many accomplishments. In any event, the army declared the coup a response to popular demand and named the new transitional government "National Liberation Council." The army then oversaw, by most accounts, fair elections in which the CPP suffered a major defeat. The country returned to parliamentary rule.

While the NLC clearly intended to be no more than a caretaker government, the authors of the next coup had far less democratic intentions, although, they, too, retained something of Nkrumah's original nation-building project. The main difference was that the coup leader, Acheampang, had a more militarized vision of what the republic should be. According to Bjorn Hettne, Aheampang's National Redemption 
Table 5.1

Regime Change in Ghana, 1957-Present

Year Event

1957 First government after independence, headed by Kwame Nkrumah (CPP) as prime minister, then president. This is known as the "First Republic."

1966 The Ghanaian Army and senior police officials launched the "Operation Cold Chop" and overthrew the Nkrumah regime. The NLC was formed and then ruled until 1969 with Lieutenant General Joseph Ankrah and Lieutenant General A. A. Afrifa as heads of state.

1969 Kofi Busia, leader of the Progressive Party (PP), was installed as a civilian leader in a democratic election, constituting what is widely known as the "Second Republic."

1972 Lieutenant Colonel Ignatius Kutu Acheampong led a bloodless coup to insert the NRC. He was head of state from 1972 to 1975.

1975 NRPC is reorganized into the Supreme Military Council.

1978 Supreme Military Council installs Lieutenant General Frederick W. A. Akuffo as head of state.

1979 Flight Lieutenant Jerry J. Rawlings leads a coup to insert the Armed Forces Revolutionary Council.

1979 Hilla Limann elected as head of state as part of the People's National Party. This starts the "Third Republic," albeit a short one.

1981 Rawlings overthrows the government and becomes head of state as part of the Provisional National Defense Council. This constitutes the "Fourth Republic."

1983 Attempted overthrow of the People's Defence Committee by other junior army men.

1992 Multiparty constitution formed.

1993 Rawlings resigns from military and is elected as part of the National Democratic Congress.

1996 Democratic election reelects Rawlings.

2001 First transition to a new power through elections that are widely cited as "free and fair," as power was handed over to the New Patriotic Party under President J. A. Kufour, who then bolstered civilian oversight of the military. He was reelected in 2005.

2009 Second political transition as J. A. Mills of the National Democratic Congress wins election.

2012 J. D. Mahama takes over presidency upon death of Mills in 2012 and is subsequently reelected later in the 2012 election. 
Council (NRC) “initiated a process of militarization of society, for instance, by appointing military officers to the top positions in all major departments, regional bodies, state corporations, and public boards." 24 Furthermore, three years later, the junta changed its name to the Supreme Military Council to resume the military hierarchy and position in power. Acheampang's tone of unification through setting up the "Union Government" was seen as solely a political construct, including rhetorical movements away from tribalism, ${ }^{25}$ and ultimately it failed through lack of support. In general, the result is that the military coups successively antagonized political parties. ${ }^{26}$

On balance, Ghana's military leaders tended not to veer far from their ostensible goals of trying to right the ship and strengthen the nation, at least when compared with the brutality and corruption of Nigeria. They tended to take seriously the requirement of meeting the people's needs and strengthen the civil service rather than weaken it. They often were sincere about acting to right the ship to save it. For example, Sang-Seek Park, in a discussion of Ghana's military rulers, noted their interest in serving the state:

But more interesting is the fact that the [Ghanaian] military had kept intact the internal structure of the civil service and even strengthened the role of the civil service. Some specialists in the military coup have observed that the civil-military coalition after a military coup is very common. The case for Ghana seems to support this hypothesis. It is not surprising that the military and the civil service support each other because the military organization is, in fact, part of the bureaucracy. ${ }^{27}$

In the 1979 coup, Rawlings explicitly stated that his objective was to have the military act first and foremost as civilians and, in effect,

\footnotetext{
${ }^{24}$ Hettne, 1980, p. 183.

25 Emmanuel Hansen and Paul Collins, "The Army, the State, and the 'Rawlings Revolution' in Ghana," African Affairs, Vol. 79, No. 314, 1980, p. 8.

26 Hansen and Collins, 1980, p. 7.

27 Sang-Seek Park, “The Military in Ghana," African Studies Review, Vol. 17, No. 1, 1974, p. 270 .
} 
serve the people in place of the civilian government because the government no longer served that function. ${ }^{28}$ Rawlings would continue to have a destabilizing effect on Ghanaian politics; however, on balance his actions helped Ghana, and he played a critical role in setting the stage for a successful transition to civilian rule and democracy. Rawlings introduced a number of reforms for the purpose of shoring up his power that had the effect of democratizing the government and professionalizing the force. ${ }^{29} \mathrm{He}$ could do this in part because he had a "close and privileged relationship" with the military, because he had acquired power through a coup, and because he had close personal ties to department leaders in intelligence and other parts of the military. Nonetheless, Rawlings successfully expanded his support base such that he had genuine popular support. It probably helped that he was able to gain access to international funding (World Bank, International Monetary Fund, etc.) while also liberalizing the regime. ${ }^{30}$

\section{Moving Forward}

Ghana since 1992 has made solid progress toward democracy, with its army increasingly circumspect with regard to its political role and assuming a truly républicain role. One of the striking aspects of contemporary Ghanaian political culture-which the military fully sharesis the role of Ghana's stability and democracy in national identity. In effect, much of what Nkrumah wanted to accomplish has transpired, although it has taken several decades for the country to reach a level of national cohesion that he hoped to impose in a matter of years. Time itself may well have played an important role: The greater the stability, the more time the military has had to focus on professionalism and, in

${ }^{28}$ Antoinette Handley and Greg Mills, From Military Coups to Multiparty Elections: The Ghanaian Military-Civil Transition, Working Paper Series, The Hague: Netherlands Institute of International Relations 'Clingendael,' 2001, p. 16.

29 For details, see Eboe Hutchful, "Military Policy and Reform in Ghana," Journal of Modern African Studies, Vol. 35, No. 35, Issue 2, June 1997.

30 Handley and Mills, 2001, p. 19. 
reality, anything other than politics, thus resulting in greater stability. Prior to 1992, the argument goes, the Ghanaian army had less time to cultivate its professionalism:

The protracted military interventions that characterized Ghana's independence interrupted efforts to introduce professional standards in the armed forces, as well as to promote civil control in the wider security sector. More significantly, each time there were military interventions, parliament was the first institution to be disbanded. This hindered the development of a culture of oversight within parliament; once the security sector was in power under the PNDC [Provisional National Defense Council], it was loathe to allow checks on its power. ${ }^{31}$

After 1992, a virtuous circle came into play, with the mostly successful democratic elections and transitions of power enabling the military to cultivate its professionalism, with ramifications for its own legitimacy and that of the civilian government it served.

Handley and Mills ascribe the legitimacy and professionalism of the Ghanaian army as coming from several factors from the political transitions: the clear and unambiguous transitioning to civilian control of military after a coup; assuring good pay and keeping the military busy in operations; and allowing the uniformed military to run itself (operations), but allowing for ultimate civilian control. The military has been able to burnish its image, in sharp contrast with memories of its past. Many in Ghana, particularly the older generation, recall the abusive military of the postcolonial, pre-early democracy period when the military ran roughshod over common people. Instituting curfews, beatings for insubordination, and disappearances are discussed widely. In addition, senior military leaders interviewed for this report were quick to point out how poorly those involved in past coups fared in general in the long run. Those interviewed expressed no romantic views of the benefits accrued to coup leaders. ${ }^{32}$ In comparison, there is ample

31 Kwesi Aning and Ernest Lartey, Parliamentary Oversight of the Security Sector: Lessons from Ghana, 1995.

32 Various personal interviews, May-July 2015. 
evidence of respect for today's military, often with regard to its competence and professionalism. In the words of one Ghanaian observer, Kwame Insaidoo:

Let us make clear that the military establishment is the most organized and efficiently managed institution in our nation. The military has many competent engineers, technicians, managers, air-traffic controllers, scientists, bridge builders, and a host of well-trained and experienced personnel than any other institution in the nation. ${ }^{33}$

The Ghanaian army's embrace of international peacekeeping as a primary mission has helped. According to Insaidoo, the high-profile deployments with UN operations enhanced the armed forces' legitimacy. The general atmosphere in Ghana, even from reading local newspapers, editorials, and person-on-the-street interviews is such that the army is at least less corrupt than other institutions, ensuring its credibility as a servant of the people. ${ }^{34}$ Critically, however, the esteem for the military does not translate to regarding the army as ideally having a governing role. It appears that, within Ghanaian society and the military, there is now an expectation that the military should behave in certain ways, and there is a consensus that one must not look to the military for a solution to political problems. In fact, it is a point of pride in Ghana that the military does not have a political role.

\section{Shapers of Normative Values}

A number of factors have contributed to positively shaping Ghanaian political culture. One is civic education, in particular the work of the National Commission for Civic Education (NCCE), which was

33 Kwame Insaidoo, Ghana: An Incomplete Independence or a Dysfunctional Democracy?, Bloomington, Ind.: AuthorHouse, 2012, p. 213.

${ }^{34}$ For the Government Defence Anti-Corruption Index report for Ghana, which describes general feelings about the military, see Ministry of Defence, Republic of Ghana, "Defence," May 2012. 
chartered by the 1992 constitution and established by the Ghanaian parliament in 1993. The constitution lists the NCCE's mission in the following terms:

The functions of the Commission shall be-

(a) To create and sustain within the society the awareness of the principles and objectives of this Constitution as the fundamental law of the people of Ghana;

(b) To educate and encourage the public to defend this Constitution at all times, against all forms of abuse and violation;

(c) To formulate for the consideration of Government, from time to time, programmes at the national, regional and district levels aimed at realising the objectives of this Constitution;

(d) To formulate, implement and oversee programs intended to inculcate in the citizens of Ghana awareness of their civic responsibilities and an appreciation of their rights an obligations as free people. ${ }^{35}$

The NCCE publishes material on the constitution. It aims the publications at the population, with the effect that, in certain circles, the population understands what is in the constitution, believes it has governing power over any possible coup, and the NCCE's work is credited with fostering among civilians a general sense that they "wouldn't stand for" another coup that undermines that structure. ${ }^{36}$ Moreover, several army leaders interviewed for this report cited the standard civil-

\footnotetext{
35 Republic of Ghana, "Constitution of the Republic of Ghana," 1992, chapter 19.

36 This was stated as such by National Democratic Congress' Deputy Defense Minister, Tony Aidoo, in Handley and Mills, 2001, p. 37, and heard from several on-the-street interviews in Ghana, April 2015.
} 
education that is provided to soldiers throughout their careers as reinforcing civic values. There is a broad consensus that the constitution is a credible underpinning of civil-military relations. ${ }^{37}$

Ghanaians' adherence to constitutional order also has longstanding roots that go back to independence in its national identity. Ghanaians, for example, have historically felt a sense of responsibility as one of the first democracies to rise from colonial rule in Africa. Ghana leads the way, a view that Ghanaians associate with their governments' consistent efforts to extend the country's influence through $\mathrm{UN}$ and African Union (AU) missions abroad. President Mahama's role in Economic Community of West African States (ECOWAS) and Kofi Annan's role as Secretary General of the UN have reinforced this aspect of Ghanaians' self-image.

The role that Ghana plays as a leading example of democratic change is both indigenously believed and externally bestowed, and part of the myth that engenders common support for civic norms. The United States, for example, has repeatedly confirmed Ghana's leading position in Africa as a stable and progressive democracy worth of emulation. Former President Barack Obama remarked in 2012 that, "Ghana has proven, I think, to be a model for Africa in terms of its democratic processes." 38 Ghanaians, at this point, would be loath to disappoint its admirers and themselves.

\section{Foundational Documents}

Also of note are the formal aspects of the Ghanaian military's embrace of republican values. The Armed Forces Bill of 1962 set an important precedent. In addition to laying the groundwork for civilian control of the forces and all that means, this act also describes expectations for the conduct of the armed forces. The bill provides a belief system to which successive military coup leaders have at least claimed adherence, and, to this day, it plays a role in how the military sees itself and how the people sees it. The Ghanaian Armed Forces News Quarterly prints

\footnotetext{
37 Several interviews repeated this notion, May through July 2015.

38 "Remarks by President Obama and President John Atta Mills of Ghana," Ghanaian Chronicle, March 12, 2012.
} 
one- or two-page excerpts each issue of the Armed Forces Act of 1962 as a means of reinforcing those expectations on the force. ${ }^{39}$

A formal defense strategy that provides a rationale for the military and its use is not publicly available; however, one can glean considerable insight from parliamentary hearings, media reporting, and budget documents that discuss military spending. For example, according to budget documents posted on the Ministry of Finance's website, the goals for the army include:

- safeguarding the territorial integrity of Ghana against external aggression

- assisting the civil authority to maintain and/or restore law and order

- enhancing the capacity of the Ghana army to participate in International Peace Support Operations

- forestalling civil strife through preemptive and proactive deployment in order to secure internal peace and security

- providing disaster relief and humanitarian assistance during national, regional and district disasters and emergencies

- participating in productive ventures and activities in support of national development.

Similarly, the documents describe the armed forces' core functions to include:

- formulating and implementing "National Defense Policies" relating to peacekeeping, internal and external security and the total defense of the nation

- defending the territorial integrity of Ghana

- providing guidance for defense leadership

- ensuring the development and capacity building of its manpower

- collaborating with other security agencies and civil authority to ensure the maintenance of law and order

39 The Parliament of the Republic of Ghana, “The Armed Forces Act, 1962," February 21, 1962, The Hundred and Fifth Act. 
- forging and maintaining closer links with civil society, the private sector and other Ministerial Organizations.

Fortunately, Ghana does not have a grave external threat, freeing the army to focus on other matters. Clearly, these include external peacekeeping, and, internally, supporting the state for the benefit of the people.

\section{Focus on Civil Support}

One reason why the civil-support role has risen to such prominence is the fact that Ghana has no clear threat from abroad, and thus its military has had to find ways to justify itself. The civil-support role can be seen in the army's support of the police against smuggling and joint army-police patrolling against general crime. It was both a means of connecting the population to the military better, and to reduce potential concerns about future unrest, but also to define a reason for existing as a government entity. Slowly, the army became more involved in civic actions that were first associated with their training, and even recently, it debated entering the private sector to engage in paid work. The perception of the army as aiding in civilian security and internal matters is apparent today as calls for them to fill capability or capacity gaps in civilian law enforcement and governance are not uncommon. ${ }^{40}$

The government is mindful of the value of high-profile civic actions as a means to counter lingering memories of military rule. The military police recently initiated joint patrolling with civilian police to bring the military police in closer contact with the population and to demonstrate their ability to address the population's problems. The media generally portrayed this activity positively, as it boosted the ability of the local police force to carry out important internal security and safety functions. ${ }^{41}$ The military similarly has conducted various

\footnotetext{
40 See, for example, Kofi Thompson, "Military's Special Forces Must Be Deployed to Halt Illegal Logging," Ghanaweb.com, June 15, 2015. The military was called to deal with alleged illegal logging in the Atewa Range of Ghana after citizens were rebuffed by police and government agencies.

41 David Anode, "Photos: Top Town Armed Robbery Victims Call for Joint Police-Military Patrols," myjoyonline.com, February 16, 2015.
} 
public-relations efforts to foster positive relations with the public and make the military appear accessible and capable of helping people "fix their problems." 42 These include ad campaigns (Figure 5.1) and general statements about the "friendly" nature of military that target civilians and the military itself.

\section{Peacekeeping}

The Ghanaian army has been deeply involved in peacekeeping operations (PKO) for several decades now as part of UN and AU and other missions. The involvement in PKO is part of Ghana's defense strategy, a justification for having an armed force, but also a fulfillment and reinforcement of aspects of Ghanaian national identity that posit a role in pan-Africanism and a general superiority to much of the rest of the continent in light of Ghana's relative stability and prosperity.

One measure of the importance of PKOs for Ghana is the fact that, as of the 2015 budget period, one-third of the force was involved in $\mathrm{PKO}$, a large number in terms of the effects participating in $\mathrm{PKO}$ would have on the force's self-identity. ${ }^{43}$ Some estimate that a typical soldier might average two deployments during his tenure. PKOs also bring a monetary value: Those soldiers deployed bring financial support back to the ministry, which helps defray other costs of running a military and helps bolster the pay of those who deploy. ${ }^{44}$ Table 5.2 shows several UN missions and the Ghanaian forces involved from the Military Balance 2016.

UN deployments also bring individual benefits to the soldiers deployed. One estimate from multiple senior leaders in the military was that it might bring several times their normal pay (which is already comparatively good in the economy) when on deployment. Some of that returns to the ministry, but the leaders we spoke with noted that sol-

\footnotetext{
42 Interview with Ghanaian Army officer in Accra, March 10, 2015.

43 Interview with Ghanaian Army officer in Accra, March 10, 2015.

44 Several studies have noted values from those deployments and different allocations of that UN money toward both individual soldier pay and to the overall MOD. Most, including our interviews, ascribe positive and meaningful financial benefit to the soldiers from the deployments. For an older account, see Hutchful, 1997, p. 270.
} 


\section{Figure 5.1}

Billboard at Entrance to Burma Camp

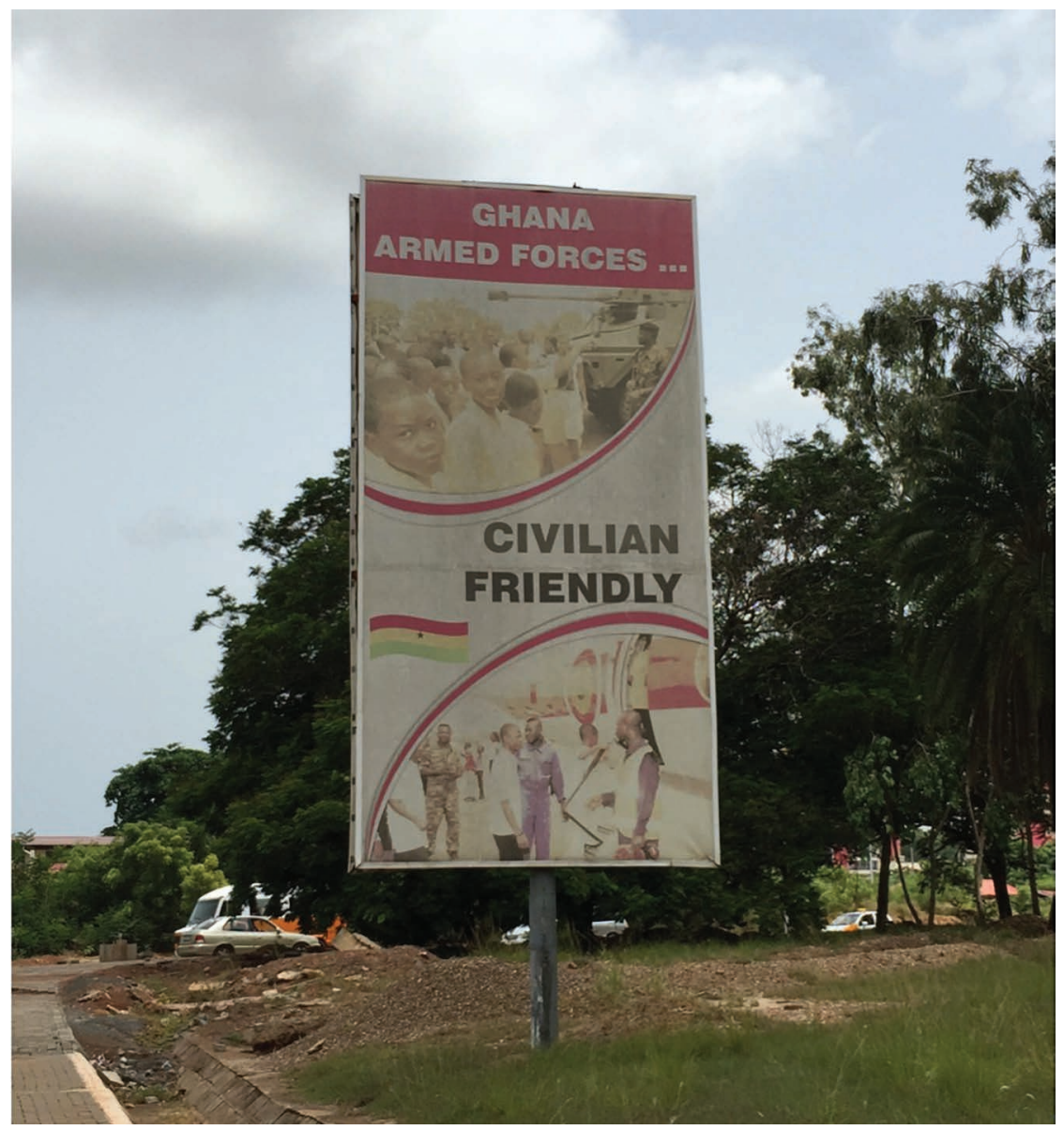

SOURCE: Photo by Chris Pernin.

RAND RR1832-5.1

diers typically can return from deployments with prospects of buying a house or cars and generally providing well for a family. The number of deployments that soldiers typically endure and the pervasiveness across the force for such deployments mean that, in general, these deployments are a large part in keeping the force financially provident. 
Table 5.2

Selected UN Missions and the Role of the Ghanaian Armed Forces (2015)

\begin{tabular}{|c|c|c|c|c|}
\hline Country & UN Mission & Forces by Role & $\begin{array}{l}\text { Number of } \\
\text { Troops }\end{array}$ & $\begin{array}{l}\text { Number o } \\
\text { Observers }\end{array}$ \\
\hline $\begin{array}{l}\text { Central African } \\
\text { Republic }\end{array}$ & MINUSCA & & & 3 \\
\hline Lebanon & UNIFIL & $1 \operatorname{lnf} B N$ & 871 & \\
\hline Western Sahara & MINURSO & & 6 & 8 \\
\hline Côte d'Ivoire & UNOCI & $\begin{array}{c}1 \text { Hel Coy, } 1 \text { Fld } \\
\text { Hosp }\end{array}$ & 156 & 6 \\
\hline $\begin{array}{l}\text { Democratic Republic } \\
\text { of the Congo }\end{array}$ & MONUSCO & 1 Mech Inf BN & 465 & 22 \\
\hline Liberia & UNMIL & $1 \operatorname{lnf} B N$ & 707 & 8 \\
\hline Mali & MINUSMA & $\begin{array}{l}1 \text { Engineering } \\
\text { Coy, } 1 \text { Fld Hosp }\end{array}$ & 160 & \\
\hline Sudan (Darfur) & UNAMID & & 18 & 8 \\
\hline Sudan (Abyei) & UNISFA & & 2 & 3 \\
\hline
\end{tabular}

SOURCE: Adapted from “Chapter Nine: Sub-Saharan Africa," Military Balance, Vol. 115 , No. 1, 2016, p. 450.

NOTE: MINUSCA = United Nations Multidimensional Integrated Stabilization Mission in the Central African Republic; UNIFIL = UN Interim Force in Lebanon; MINURSO = UN Mission for the Referendum in Western Sahara; UNOCI = UN Operation in Côte d'Ivoire; MONUSCO= UN Organization Stabilization Mission in the Democratic Republic of the Congo; UNMIL = UN Mission in Liberia; MINUSMA = UN Multidimensional Integrated Stabilization Mission in Mali; UNAMID = UN-African Union Mission in Darfur; UNISFA = UN Interim Security Force for Abyei. Total =1,901.

The involvement in so many PKOs is reflective of the Ghanaian role and perceived responsibilities in the African continent. This may have created "international and domestic prestige" with those successful deployments. The training that is necessary for the armed forces to engage in those PKOs is also substantial and adds to their professionalism and capabilities. The U.S. Department of State's Africa Contingency Operations Training and Assistance mission is to "enhance the capacities and capabilities of its African Partner Countries, regional institutions, and the continent's peacekeeping resources as a whole so that they can plan for, train, deploy, and sustain sufficient quanti- 
ties of professionally competent peacekeepers to meet conflict transformation requirements with minimal non-African assistance." 45 The program trains peacekeepers prior to deployments, which enhances organic capabilities in general. Throughout these activities, the Ghanaian forces have become knowledgeable of the UN system and how it works, which some leaders we interviewed believe makes them that much more attuned to and valuable to peacekeeping and supporting international institutions. ${ }^{46}$ These activities and deployments provide several benefits, from the direct training value to the international involvement.

It is also worth noting that Ghanaian forces involved in UN PKOs reportedly are particularly enthusiastic about and good at civil-military cooperation operations (CIMICs), which often entail humanitarian and reconstruction activities. According to one comparative study of different PKO contingents, Ghanaians stand out for making CIMIC a priority and also for bringing to the task notable creativity. ${ }^{47}$ Given the Ghanaian emphasis on CIMIC, it is possible that the activity influences their own approach to civil-military relations in their own country. PKO deployments also affect Ghanaians' appreciation of their own country. Seeing firsthand, through multiple tours, the problems other nations face, and the devastation social unrest can bring to the livelihoods of its citizenry, creates a force attuned to that destruction. Some senior army leaders we spoke with believe this sensitivity to unrest is then applied when those soldiers are back home, when their support for stability is then manifested to ensure "not in my house." 48

The importance of operations to the rank and file in the military is equally reflected in the leadership's ability to inform and influence broader regional African operations and politics. President Mahama's

45 U.S. Africa Command, "Africa Contingency Operations Training \& Assistance (ACOTA)," africom.mil, undated.

46 Author interview with multiple senior army officers in Accra, July 10, 2015.

47 Chiara Ruffa, "What Peacekeepers Think and Do: An Exploratory Study of French, Ghanaian, Italian, and South Korean Armies in the United Nations Interim Force in Lebanon," Armed Forces and Society, Vol. 40, No. 2, 2013, p. 208.

48 Author interview with multiple senior army officers in Accra, July 10, 2015. 
chairmanship of ECOWAS has provided an opportunity for Ghana to be more involved in local and regional issues that have far-reaching implications for how the army is viewed. Their leading role in the Ebola crisis of 2014 bolstered their credibility and cache in the region. $\mathrm{AU}$ and UN missions, and setting up a Joint Task Force in Nigeria for Boko Haram, increased their importance in the region and allowed a sense of nationalistic pride to be enjoyed throughout the military. Many regard President Mahama as influential in regional matters, relying in many ways on the professionalism and tenor of the Ghanaian army to successfully build that legitimacy.

\section{Compensation Stability}

One seemingly small yet nontrivial factor that has contributed to Ghana's success is the steadiness with which it has managed to pay for its military. The Ghanaian economy has endured several up and down periods, but lately it has been enjoying a period of growth associated with wealth from the sale and development of indigenous natural resources and external inputs from the international community. This has allowed the military to remain relatively well financed, which encourages a sense of stability in the ranks. ${ }^{49}$ Key to an appropriately financed military is stability in funding and pay scales that ensure soldiers are paid - not too much, not too little. As mentioned earlier, the deployments for UN operations aid in assuring that places in the Ghanaian military remain competitive and sought after.

\section{A U.S. Role?}

The evident success of the Ghanaian military and its civic virtues begs the question of whether U.S. SA has helped. There is not enough evidence to establish a strong correlation one way or another. What we do see is congruence between the Ghana's needs and the kinds of SA the United States has provided. The United States has not recruited Ghana to join the war against terrorism, and Ghana has not needed to build

49 Author interview with a senior officer in Accra, April 7, 2015. 
a force capable of meeting external threats or performing counterterrorism or COIN missions. Ghana has, however, needed a force that performs PKOs well and that supports Ghana's development by being civic, républicain, or what the Senegalese call an armée-nation. U.S. assistance to the Ghanaian military more or less has focused on precisely those things: According to a list of priorities published by $\mathrm{DoD}$ and the State Department, U.S. objectives for SA or SFA are:

- military professionalization

- adherence to norms of human rights

- civilian control of the military

- peacekeeping

- maritime security and transnational threats..$^{50}$

The principle tool used for assisting the Ghanaian military is the International Military Education and Training program, which includes dozens of Ghanaian attendees in U.S. education and training programs. ${ }^{51}$ U.S. professional military education (PME) in Ghana focuses on civilian leadership, professionalization of the military, and other educational indoctrination. Senior officials comment on the importance of these efforts: that those in the military (mostly those in the air force or navy, less so in the army) get a good education on the role of the military in society from PME courses and from the U.S. involvement. Of course, PME is not precisely ideological and does not school Ghanaian officers in promoting national ideology, but it can be argued that Ghanaians already possess such an ideology and understand its importance; Ghanaian ideology already is built into Ghanaian military culture. U.S. training, therefore, can be said to help the Ghanaians do something they are already doing on their own.

50 DoD, Foreign Military Training: Fiscal Years 2013 and 2014, Joint Report to Congress, Vol. 1, Washington, D.C., March 26, 2014, p. 8.

51 A total of 1,500 Ghanaian officers have gone through U.S. IMET training as of fiscal year 2014, almost the same number of Nigerian officers. Ghana's military is, of course, much smaller, meaning that a significantly large proportion of Ghanaians have gone through IMET. See Defense Security Cooperation Agency, Historical Facts Book, Washington, D.C., 2014, p. 125. 


\section{Conclusion}

Ghana's present army exhibits many of the traits mentioned elsewhere in this report that support nation-building writ large. The Ghanaian force is securing its goal of nation-building by benefiting from coming off several postcolonial coups and instilling a belief system for civilian control, finding and supporting a purpose for the army that mutually supports the state and its identity to be a leader in the region, and helping the army to connect with the population in progressive and purposeful ways. Clearly, within Ghanaian society and its military, normative values that are conducive to liberal democracy have become predominant. Most of the credit must go to Ghana's civilian and military leaders. 


\section{The Malian Army}

Mali's military recently has come under considerable scrutiny. Despite having received assistance from a variety of international partners, among them the United States, the Forces Armées Maliennes (the Malian Armed Force [FAMa]) — which includes the army, the air force, and three internal security services-have proven feckless on the battlefield. ${ }^{1}$ The Malian army's record historically has been poor, but when a Tuareg militant group launched a rebellion in 2012, which was soon joined by a variety of other groups, including three Islamist terrorist groups, they inflicted a nearly unbroken string of lopsided defeats on the army that continues to this day. To make matters worse, in March 2012, a group of Malian army officers launched a coup and deposed the country's elected president, which only resulted in greater disarray and the termination of U.S. support. Indeed, the FAMa's record makes clear that it represents a greater menace to its own country-not just because of the coup but also its tendency to abuse local populations, commit human rights violations, and alienate key northern Malian communities - than it does to Mali's enemies. Still, the international community is betting that it can improve the FAMa at least enough to be able to reduce its own direct contribution to Malian security: France and the UN for all intents and purposes have assumed primary responsibility for security in Mali and are conducting military operations there; both would like nothing more than to be able to hand

1 The three internal security services are the paramilitary Gendarmerie Nationale; the Garde Nationale, which is an irregular force that historically patrolled Mali's deserts; and the Police Nationale. 
off the often dangerous work to the host country. The United States intends to resume assistance and currently is in the process of sorting out Mali's security needs and identifying opportunities for constructive engagement.

The FAMa's failures and those of the army in particular have many causes, such as poor human resource management and poor maintenance and training. Units that fought well in 2012-including U.S.-trained units - sometimes came to grief because they ran out of ammunition and could not be resupplied; some besieged units had to surrender after relief attempts failed. ${ }^{2}$ Command and control failures are often cited as problems, and Malian forces have demonstrated an inability to conduct coordinated offensive operations. ${ }^{3}$ These problems are well understood, and the French, the UN, and the European Union Training Mission in Mali (EUTM) and the European Union Capacity Building Program in Mali are actively working to address them. However, a number of the Malian army's failures are of a different nature. Low morale is a general problem and arguably has undermined units' determination to fight. This problem has ethnic and demographic dimensions, as Mali's predominantly southern and "black" African force tends not to identify with northern Mali, resents serving there, and lacks motivation with respect to fighting for it compared with the rebels who are from northern Mali and who are highly motivated. Similarly, many of the U.S.-trained units disintegrated when Arab and Tuareg soldiers deserted or defected to join their co-ethnics in the enemy forces. Finally, to a significant extent, the FAMa's relations with northern communities and its poor human-rights record has undermined the state's legitimacy and fueled the conflict between northern communities and the government in Bamako. The army in particular treats the north as if it was a foreign land and historically has applied to it a heavy hand.

2 Laurent Touchard, “Guerre au Mali: retour sur le drame d'Aguelhok," JeuneAfrique.com, October 21, 2013b.

3 Laurent Touchard, "Défense: où en sont les Forces armées maliennes?" Jeuneafrique.com, June 11, 2014b; Laurent Touchard, "Armée malienne: les affrontements de Kidal, chronique d'une déroute annoncée," JeuneAfrique.com, May 27, 2014a; Laurent Touchard, "Mali: retour sur la bataille décisive de Konna," Jeuneafrique.com, January 30, 2014 c. 
In other words, Mali represents a clear case where attending to the host-nation's force structure and tactical capabilities is insufficient to create the desired result, as articulated not just by U.S. policy in Mali but also U.S. doctrinal publications regarding COIN and stability operations: a force that contributes to state legitimacy. Building the FAMa into a national force-a républicain army or an armée-nationthat meets the country's political needs (i.e., fostering cohesion and contributing to the legitimacy of the Malian state) is something that Bamako and Mali's partners alike have yet to make a priority. Indeed, to date there has been little effort to create a military that matches the country's requirements with respect to politics and security. Historically, Bamako has thought of its army as having an external security mission, which meant building a conventional force. More recently, the focus at least for Mali's partners_-including the United States-has been on a narrow counterterrorism mission. In the past, Mali might have needed a conventional military: Twice it has gone to war against Burkina Faso. Now, however, its primary mission is holding the country together and fostering state legitimacy in the face of armed insurgents.

\section{Background to Mali's Conflicts: Diversity and National Identity}

Historically and culturally, Mali's two halves have always been distant despite interactions in central Mali along the so-called Niger River Bend. Southern, subtropical Mali, as well as the Bend, are apt for cultivation and settled communities; northern Mali-much of which is in the Sahara-has limited agricultural potential and traditionally has relied on nomadism and trafficking. They are, in effect, two different societies comprised of different ethno-linguistic groups.

Mali's ethnic composition is difficult to establish given the paucity of relevant census or other polling data. Roughly one-half of Mali's population can be associated with the Mandé (alternatively Mande) family of ethnic groups, which includes Bambara, Malinke, and 
Soninké peoples. ${ }^{4}$ These, above all the Bambara, have historically dominated Mali and do so today. Alongside them are other "black African" groups, including the Songhay (6 percent) and the traditionally nomadic Peul (Fulani) (9.4 percent). Arabs and Tuaregs are estimated to constitute 10 percent. $^{5}$ Although language data are imprecise proxy for assessing the size of ethnic groups, just less than one-half of Mali's population speaks Bambara, and only 3.5 percent speak Tamashek, the Tuareg language. ${ }^{6}$

Also notable are data from the 2009 census indicating where people in Mali live. Out of a total population in 2009 of 14.5 million people, only 1.3 million people resided in Mali's three vast northern regions of Gao, Kidal, and Timbuktu, or just less than 10 percent of the population. A significant portion of those 1.3 million comprise Arabs and Tuaregs, but one also finds Peuls and Songhay. The Mandé and other "black Africans" are concentrated in Mali's southern half.

The French during the colonial period paid more attention to the south than the north, were more present in the south, and governed it more directly, meaning that southerners were generally more integrated into the colonial state, more likely to be enrolled in French schools, and more directly influenced by contact with the French. The Tuareg in particular were among the least involved in the French administration and had the least contact with, among other things, the French school system. ${ }^{7}$ That said, northern Malians, the Tuaregs in particular,

4 CIA, “The World Factbook: Mali," cia.gov, January 12, $2017 \mathrm{~b}$.

5 CIA, 2017b.

6 For a lengthy discussion of demographic estimates in Mali and the problems associated with linguistic data, see Sara Randall, Where Have All the Nomads Gone? Mali Censuses 1987 and 1998, Note de recherche, Montreal, Canada: Observatoire démographique et statistique de l'espace francophone/Université Laval, 2012.

7 Schools have always been a key feature of French colonial rule. Tellingly, the French concentrated on building schools in southern Mali, opening fewer schools in the north, and doing so much later. Tuaregs reciprocated the disinterest and enrolled few children in the schools. Tuareg in the north (Adagh) attended less than in the south, particularly among the southern Kel Antessar of Goundam. Nobles, moreover, attended less frequently than Tuaregs of lower castes. See Alessandra Giuffrida, "Métamorphoses des relations de dépendance chez les Kel Antessar du cercle de Goundam," Cahiers d'études africaines, Vol. 3, No. 179-180, 
regarded the French more positively than the southerners and were at best ambivalent about their departure. Many preferred a French proposal for carving out a Saharan autonomous zone that would remain under French control, but the plan went nowhere, and northern Malians, without necessarily understanding why, found themselves under southern control in 1960.

It should also be noted that the very idea of modern Mali and independence from France emerged in the southern part of the country, primarily among Bambaras. ${ }^{8}$ Baz Lecocq explains that at the core of (southern) Malian identity is a foundational myth - the epic of the Mandinka king, Soundiata Keita, who founded the medieval Empire of Mali. Keita's empire eventually fell to a succession of kingdomsmany Bambara-and so-called jihad states, all of which Malians tend to blend together into a historical myth linking them with the present state. The myth is fundamental to the identify of Mali's Mandé peoples:

The history of the founding of the Mali Empire by [Soundiata] Keita forms the explanatory basis and justification of Mande social, cultural and political organization. The [Soundiata] epic serves to explain the relation between various Mande family groups ... villages and social strata. Without knowledge of this epic, a Mande simply cannot function socially or culturally. The same can be said about the Songhay and their empire, the Fulbe and their jihad-states and the Bambara kingdoms, which are presented in the national myth ... as the rightful heirs to the Malian empire. ${ }^{9}$

Upon obtaining independence, the Malian state used its history to craft national unity. Thus, according to Lecocq, the Modibo Keita regime adopted the name Mali and presented the new republic

2005; Pierre Boilley, Les Touaregs Kel Adagh: Dépendances et révoltes: du Soudan français au Mali contemporain, Paris: Karthala, 1999, pp. 219-234.

8 Baz Lecocq, Disputed Desert: Decolonization, Competing Nationalism and Tuareg Rebellions in Northern Mali, Leiden, the Netherlands: Brill, 2010, pp. 41-47.

9 Lecocq, 2010, p. 71. 
as the rightful heir to its medieval predecessor and its succeeding kingdoms. Of course, Keita, too, like many Malians, shares the name of the empire's founder, and, as Lecocq points out, it is beyond doubt to any Malian that he and others who bear the same name are descendants of the great imperial family. ${ }^{10}$

Almost paradoxically, Malian national identity is both elastic in the sense that it includes other population groups such as Songhoy while still imposing a Mandé stamp in the sense that is assimilates everyone else into the Mandé narrative. It seems that Malian national identity reached a limit, however, when it came to Tuaregs. According to Lecocq, Malian leaders' "image of the nation along Mandé lines" ran athwart their "ideas and images" about the Kel Tamasheq (i.e., Tuaregs): ${ }^{11}$

Malian political leaders made it quite clear that they perceived the Kel Tamasheq, their 'whiteness' and their [nomadic] way of life as a problem. This was because in the mind of the ruling ... elite, the Kel Tamasheq had been colonial favourites because of their 'whiteness,' which had given them a misplaced superiority complex. ${ }^{12}$

Lecocq, citing Malian government statements and Malian discourses in general regarding Tuaregs, demonstrates how Malian elites persisted in affirming Tuaregs' otherness and excluding them from their definition of who is a Malian. It should not be surprising, then, that Tuaregs from the north object when members of Mali's dominant Bambara ethnic group, southerners who largely control the government, evoke the memory of past Bambara empires as fundamental to Malian national identity. ${ }^{13}$ "We need a new definition of the nation that includes us," said the head of a Tuareg culture organization from Kidal.

\footnotetext{
10 Lecocq, 2010, p. 71.

11 Jean Sebastien Lecocq, That Desert is Our Country: Tuareg Rebellions and Competing Nationalisms in Comtemporary Mali (1946-1996), Amsterdam: Academisch Proefschrift, Universiteit von Amsterdam, 2002, p. 96.

12 Lecocq, 2010, p. 101.

13 Interview with Tuareg Cultural Association President, Bamako, October 8, 2013.
} 
An Arab leader described the problem in terms of how the Malian state related to northern Arabs. Invariably, he argued, despite Arabs' sincere desire to be a part of the Malian nation, the Malian government would reinforce their feeling that they were "second degree citizens." 14 Similarly, an Arab notable complained that the Malian army "goes around with interpreters who do not know the local language."15 A second Arab notable observed that the state has been partisan to intercommunal conflicts, picking sides rather than trying to build the nation and "attract everyone."16

The Malian army reflects Mali's Mandé-centric identity. Paradoxically, a contributing factor is southern Mali's diversity and the commendable capacity of southern Malians-FAMa officers includedto weave even non-Mandé peoples into a "big tent" approach to who is Malian. They see their own diversity and thus struggle to accept allegations to the contrary. For example, Malian officers, when interviewed for this project, responded negatively to questions regarding the force's precise ethnic makeup in part because, for them, the force's diversity was so self-evident and so "normal" that it seemed odd to them that one might concern oneself with the matter. As one officer put it, Malians are the same because they all are at least the spiritual descendants of Soundiata Keita. ${ }^{17}$ This is, of course, an essentially Bambara- or Mandé-centric view of Mali's history and what it means to be Malian. One finds it repeated in various Malian sources as well as Mali's military history museum in Bamako, which attempts to establish a continuity between the army, Keita, and other heroes of precolonial Mali-including men who defeated Bambara states and imposed their own-by way of Mandé traditional hunting guilds (Dozos). This is a classic example of the kind of forgetting that usually is involved

\footnotetext{
14 Interview with Berabiche leader, Bamako, October 4, 2013.

15 Interview with Berabiche leader, Bamako, October 4, 2013.

16 Interview with Arab leader, Bamako, October 11, 2013.

17 Interviewed at Gao, January 21, 2015.
} 
in the formation of national identities. ${ }^{18}$ Similarly, Malians also like to include among Keita's spiritual heirs any who resisted French colonization, an approach that overlooks the indifference or active support that characterized most Malians' response to the French penetration. Intriguingly, Malians' understanding of what it means to be Malian is sufficiently elastic to enable them to claim as yet another heir to Keita the early 20th-century Tuareg warlord, Firhoun ag Alincar, who in 1916 launched a jihad against France. The officer mentioned cited Firhoun; Mali's military museum includes him in its pantheon of "Malian" military heroes. Indeed, the FAMa base in Gao is in fact named for Firhoun (Figure 6.1).

As well intentioned as this "big-tent" approach may be, it falls flat with respect to real relations with northerners. One reason might be that the effort to link Mali with Firhoun goes too far: Few northerners resisted the French, and fewer today look on French rule with any particular bitterness. Moreover, many used the French arrival as an opportunity to rid themselves of the domination of Firhoun's confederation: When he called for jihad, no other groups rallied to him, and the Kel Adagh and the powerful Kunta Arabs actively fought him on France's side. ${ }^{19}$ Another reason is that the attempt to include the Tuareg leader in Mali's elastic self-definition flies in the face of other, more tangible acts and statements that make clear that southerners tend not to identify with Arabs and Tuaregs.

Among the better illustrations of the divide between the army and Mali's northern populations is the testimony of Amidou Mariko, who, in his memoir, recounts his military career beginning in the French colonial army in the 1950s and ending in the 1990s. Mariko describes participating in the first Malian mission to the north in 1962,

\footnotetext{
18 "Forgetting, and I will even say historic error, are an essential factor in the creation of a nation, and it is this that the progress of historical studies often puts national identity in danger." Ernest Renan, Qu'est-ce qu'une nation? Paris, France: Presses Pocket, 1992, p. 41.

19 For discussions of Firhoun, his tribal confederation (the Menaka-based Iwellemeden), and the French conquest in general, see Boilley, 1999; Hélène Claudot-Hawad, "Iwellemeden Kel Ataram," Encyclopédie Berbère, Aix-en-Provence, France: Edisud, 2003; Charles Grémont, Les Touaregs Iwellemedan (1647-1896): Un ensemble politique de la Boucle du Niger, Paris: Karthala, 2010a.
} 
Figure 6.1

The Gateway to the Army Base in Gao Named After the Tuareg Leader Firhoun ag Alincar

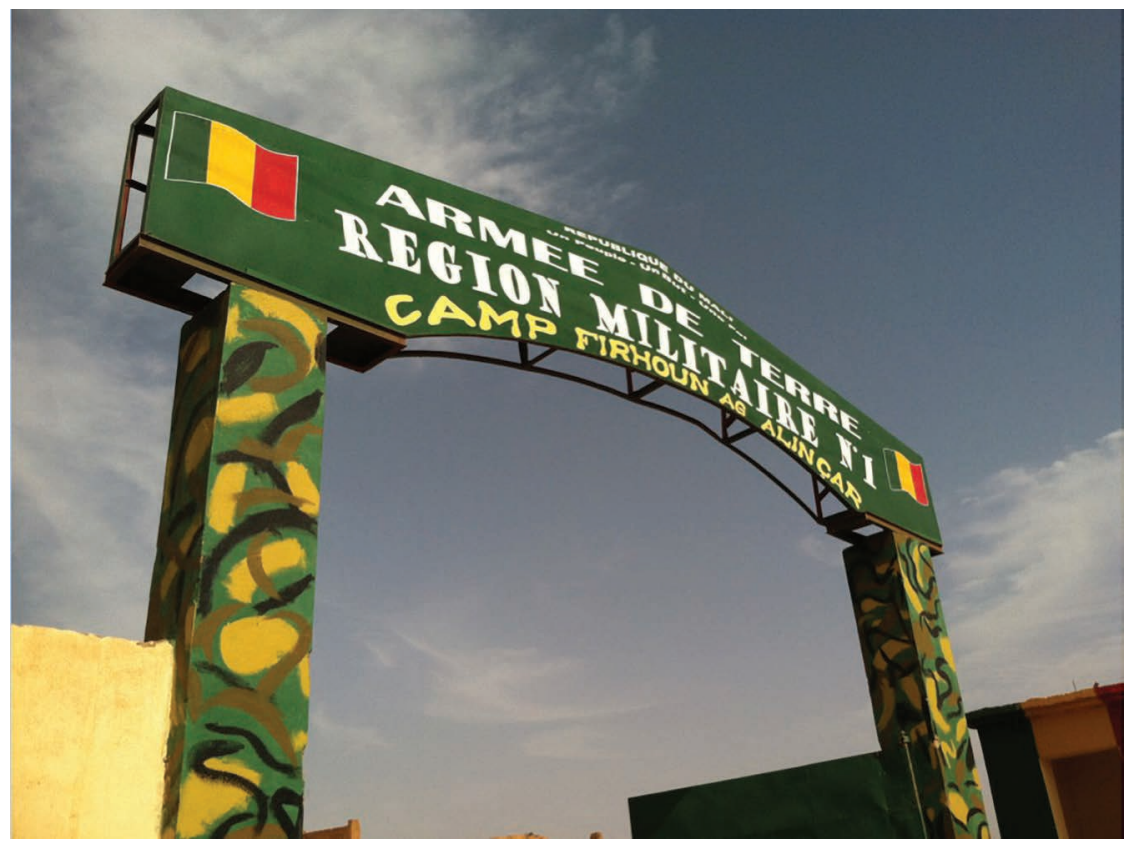

SOURCE: Photo by Michael Shurkin.

RAND RR1832-6.1

just months after the last French forces left. Malian soldiers, he asserts, simply were unfamiliar with the north and its people:

As with the large majority among us, it was my first contact with the region. Before, I did not even know the name "Tessalit" [a town in Mali's far north]; I had never heard the village spoken of before. It was also my first encounter with the population that lived there. The first impression that I had was that I was no longer in Mali. The environment was different, the people were 
different. I really felt like I was in a foreign land, far from my home, far from Mali. ${ }^{20}$

The ignorance, according to Mariko, was mutual. For one thing, he writes, no one explained to the locals why the French were leaving, who these people who were coming to rule over them were, and why. Worse, according to Mariko, in the Kidal region, the locals' only contact with black Africans was with captives-Kidal's fortress was used as a penal colony for prisoners from the south-or former slaves. ${ }^{21}$ Thus, submitting to the authority of black soldiers did not come naturally. ${ }^{22}$

Mariko describes both sides gradually inching toward a measure of familiarity until the outbreak in 1963 of a rebellion by some members of the Tuareg community - a rebellion he insists resulted entirely from a misunderstanding. ${ }^{23}$ Once it began, the army was heavy handed in its tactics and, by all accounts, needlessly cruel. One problem, according to Mariko, was that most Malian troops in the north were veterans of the French army who had served in Algeria, where they had learned to deal harshly with Algerian partisans, meaning, among other things, that they did not understand the local actors well enough to understand that the conflict was altogether different. ${ }^{24}$ According to Mariko, who claims to have been a first-person witness, Malian soldiers commonly tortured Tuaregs taken into custody and summarily executed innocents. ${ }^{25}$ Malian troops also booby-trapped or sealed wells and slaughtered livestock, measures that were taboo in a region where everyone depended on water and their animals. ${ }^{26}$ There was, moreover,

${ }^{20}$ Amidou Mariko, Mémoires d'un crocodile: Du sujet français au citoyen malien, Bamako, Mali: Éditions Donniya, 2001, p. 48.

21 Mariko, 2001, p. 49.

22 Mariko, 2001, p. 50.

23 Mariko, 2001, pp. 53-54.

24 Mariko, 2001, p. 51.

25 Mariko, 2001, pp. 64-66.

26 Mariko, 2001, pp. 63-64. 
no effort to inform either southerners or northerners about each other or foster any sort of cultural understanding:

\begin{abstract}
One needed to explain to the southerners who the northerners were and not send any administrator, soldier, or customs official without making him understand what he needed to do where he was being sent. One needed to inculcate in them the idea that the people of the north were also Malians and not [Algerian guerillas]. ... One needed to understand and make understood that we were not a colonial army, something that should have been the minimal requirement in a country that had only recently become independent, and that we must not comport ourselves as such. One could have avoided abuses of power and exactions that shocked people. Some Malian soldiers thus did things that angered the population. We did few patrols, but those that did arrive in [nomad] camps made them hand over their animals. And in towns, in Kidal, Tessalit, and Aguelhok, the administration requisitioned the young girls and even the married women for itself or for passing official delegations. ${ }^{27}$
\end{abstract}

By all accounts, FAMa's suppression of the 1963 Tuareg revoltwhich involved only a handful of Tuareg clans that represented a small minority of the overall Tuareg population-did significant damage to Tuareg perceptions of the Malian state and set the stage for later troubles. ${ }^{28}$ Bamako appears not to have concerned itself with improving relations. ${ }^{29}$ Mariko, who would return to the region on several occasions and ended up being the military administrator for the Kidal region in

\footnotetext{
27 Mariko, 2001, p. 52.

${ }^{28}$ For a discussion of the 1963-1964 Tuareg revolt, see Boilley, 1999, pp. 317-350; Lecocq, 2010, pp. 181-226.
}

29 Bamako after 1964 treated much of northern Mali as a military zone and systematically discriminated against Tuaregs and in many ways abused them. For a firsthand account, see Mariko, who describes, for example, the systematic "appropriation" of Tuareg women for sex, often for the sake of entertaining visiting delegations. Added to that are a variety of economic and legal measures, all of which were contrary to Tuareg interests. The final straw in the 1970s and 1980s arguably was the government's lack of concern for and theft of aid to Arabs and Tuaregs who were badly afflicted by severe droughts. See also Mariko, 2001; Boilley, 1999, pp. 351-406. 
the 1990s, describes being completely on his own in his efforts to break down cultural barriers and build trust, often through simple measures such as hosting dinners: Neither his colleagues in the army nor his superiors supported him or approved, and, on several occasions, his efforts to deal with the 1990-1996 insurrection by working with community leaders and avoiding heavy-handed tactics met with insubordination. Moreover, whereas the French routinely recruited Tuaregs into its colonial security forces, the army made no effort to integrate Tuaregs prior to $1993 .{ }^{30}$ There were some in FAMa, but most were in the Garde Nationale who generally served as guides. Those in the FAMa had little hope of promotion: Grémont writes that, to his knowledge, only two or three Tuaregs became officers between 1960 and 1993. Most of the Tuaregs in the FAMa deserted with the outbreak of rebellion in 1990.31

What happened in 1993 was the result of peace negotiations as well as the 1991 coup, which brought about both a wide-reaching effort to democratize and decentralize Mali and a disarmament, demobilization, and reintegration program involving the integration of Arab and Tuareg rebel fighters into Mali's security forces, the army among them. The first group joined the ranks in 1993; there would be several others subsequently, with the total reaching "more than 2,500" in 1996.32 For a force of around 15,000 (for all of the FAMa, with roughly 8,000 in the army), this represents a large number. More came between 2006 and 2009 as a result of the rebellion of those years. The army also began recruiting directly from Arab and Tuareg communities, although the precise numbers involved remain unclear.

The available evidence suggests that, although the FAMa was willing to integrate Arabs and Tuaregs into the force, its relations with northerners remained fraught. First, Bamako undermined its own claims of acting toward northerners in good faith by sponsoring a Songhay proxy militia known as the Ganda Koy. In the 1990s, the Ganda Koy, probably with at least tacit approval from Bamako, attacked Arab

30 Charles Grémont, Tuaregs et Arabes dans les forces armées coloniales et maliennes: Une histoire en trompe-l'ail, Paris: Ifri, 2010b, p. 12.

31 Grémont, 2010b, p. 14.

32 Grémont, 2010b, p. 18. 
and Tuareg civilian populations, provoking both to attack Songhay civilians with their own militias. ${ }^{33}$ The resulting bloodshed was the worst of the entire 1990-1996 conflict. Second, Bamako's use of the Ganda Koy reflects what might be regarded as a ham-fisted attempt to follow the French colonial model of dividing and conquering using local allies and proxies. Among Tuaregs, for example, Bamako backed certain factions until the 2006-2009 rebellion, when Bamako in effect switched sides and backed a rival Tuareg faction. The latter, associated with the a specific subgroup within the Tuareg population and led by then-colonel and now-General El Hadj ag Gamou, forms the core of a new state-sponsored militia known as the Imghad Tuareg and Allies Self-Defense Group (Groupe Autodéfense Touareg Imghad et Alliés [GATIA]), which Bamako-in light of the army's impotence-is using as a weapon to exert pressure on other Arab- and Tuareg-armed groups hostile to Malian control. Third, there is Mali's failure even to attempt meaningfully to integrate Arab and Tuareg soldiers.

The most obvious indicator of the failure to integrate Arab and Tuareg soldiers is the mass desertion of anywhere from 30 to 70 percent of them in 2012 following the January revolt by a Tuareg armed group and the rapid string of military successes by the rebel group and three Islamist groups, all of which were dominated by either Arabs or Tuaregs. Among the deserters were Tuaregs who were part of counterterrorism units that had received U.S. training, specifically units that, since 2009, had received repeated training from U.S. Special Forces Joint Combined Exchange and Training (JCET) teams. ${ }^{34}$ Some of those who deserted in fact defected-joining one of the armed groups arrayed against Bamako. Others simply went home to protect their families or seek safety abroad. The numbers belonging to each category are unknown.

Discussions with Malians regarding the desertions reveal several problems. One is a lack of confidence in the Malian state as well as a

\footnotetext{
33 Grémont, 2010b, p. 17.

${ }^{34}$ For a discussion of the JCET-trained Malian units and the events of 2012, see Simon Powelson, Enduring Engagement, Yes, Episodic Engagement, No: Lessons for SOF From Mali, thesis, Monterey, Calif.: Naval Postgraduate School, 2013.
} 
sense that, ultimately, southern Malians do not regard the north as part of their country. For example, an Arab colonel who deserted and then joined an Arab armed group said that Mali's abandonment of the north in 2012 signaled to him that Mali did not care enough about the north to defend it and that ultimately his community was on its own. He said, moreover, that even though his career as a FAMa officer went well and he was never mistreated, the southerners never let him forget that he was different.

Current Malian military leaders concede that integration was mismanaged or, to be more precise, not managed at all. There was no policy formulated to guide the former rebels' integration, no effort to distance them from their former allegiances or even the hierarchies that existed prior to leaving their rebel groups, and no effort to cultivate among the integrated troops the idea that now they were Malian officers and soldiers, with specific associated obligations. According to one Gendarmerie Nationale commander,

We thought it was sufficient to give them a uniform and some money, and a little training. It wasn't enough. . . . The point was to create citizenship, but we didn't do that. We need to form them in citizenship. ${ }^{35}$

Although those interviewed said that, in general, they were aware of the specific Arab or Tuareg "fraction" to which the integrated soldiers belonged-meaning their caste, clan, or tribal affiliations, which often correlate with membership in specific militias or loyalty to specific militia leaders - they put little thought into managing the politics of the integrated soldiers or attempting to integrate them or finding working balances. In the words of one Malian general, "We did not pay attention to divisions among the integrated soldiers. Perhaps we were naïve." 36

The exceptions appear to be dependent on individual initiatives. Mariko, for, example, writes that "without having received an order

\footnotetext{
35 Interview with Gendarmerie Nationale colonel, Bamako, January 23, 2015.

36 Interview with major general, Bamako, January 22, 2015.
} 
from Bamako," he set about training the first integrated soldiers and teaching them how to be Malian soldiers. ${ }^{37}$ At some point, he had to overcome the reluctance of his subordinates to have the integrated soldiers housed on FAMa bases so that they would live with southern troops and share facilities with them. Little by little, he said, the men got to know and trust one another. ${ }^{38}$ However, elsewhere, other commanders kept the former rebels at arms' length, not trusting them enough to give them access to military facilities or supplies. They kept the integrated soldiers at a literal and figurative distance, marginalizing them and exacerbating mutual distrust. Mariko also notes the persistence of intracommunal tensions among the integrated soldiers, who came from rebel groups that often fought one another. Thus, when he picked an integrated officer from one former rebel group for a mission, that officer would select only men from that group to go with him. ${ }^{39}$ Likewise, when he picked an integrated officer from a rival group, that officer would select only fellow veterans of that group. ${ }^{40}$

Although difficult to prove, the FAMa's continued failure to overcome north-south divisions has real bearing on its alleged bad behavior. Indeed, recent reports by the UN and Human Rights Watch document ongoing human rights abuses, primarily in the north on the part of the FAMa as well as its local ethnic militia proxies, including arbitrary arrests, rape, torture, and summary executions. ${ }^{41}$ Ultimately, northerners persisted in regarding the army as a net source of insecurity, and northern leaders associated the problem with the need for the army to be more civic or républicain.

\footnotetext{
37 Mariko, 2001, pp. 182-183.

38 Mariko, 2001, pp. 182-183.

39 Mariko, 2001, p. 187. The Armée révolutionnaire de libération de l'Azawad (Revolutionary Liberation Army of Azaward [ARLA]) represented primarily Kel Adagh commoners, known as Imghad. General Haji ag Gamou was the ALRA commander in the 1990s.

40 The Popular Movement of Azawad (MPA) was led by elite Kel Adagh nobles and defended Kel Adagh prerogatives and the primacy of the Kel Adagh chief, or Amenokal. The MPA leader was Iyad ag Ghali.
}

41 “Mali: Lawlessness, Abuses Imperil Population,” Human Rights Watch, April, 14, 2015. 
One indication that the Malian military still has a lot of work to do can be found in the January 2015 issue of the army magazine Le Guido, which the army distributed to foreign military officers who attended an "Army Day" ceremony. The issue features a full-page laudatory profile of GATIA. Alarmingly, the article singles out the Imghad as the only Tuareg who loyally defended Mali. ${ }^{42}$ This assertion, aside from being factually inaccurate, can only reinforce and give credence to suspicions that Bamako is uninterested in civil equality and representing all of Mali's people and has taken sides in some ethnic communities' conflict with others.

\section{Security Force Assistance Prior to 2012}

Following Mali's independence, a number of countries have provided various forms and levels of SA to Mali, most notably France and the Soviet Union. The United States also provided SA in the 1990s after Mali's transition to democracy in 1991.43 The French and Soviet assistance focused on conventional military capabilities in line with the Malian army's understanding of its mission at the time: external defense. The assistance the United States provided prior to the terrorist attacks on September 11, 2001, much smaller in scale than what the French and Soviets provided, focused on helping Malian and other African militaries become more proficient at peacekeeping operations. ${ }^{44}$

U.S. SA changed significantly after 9/11, when the United States folded Mali into the Global War on Terrorism. There was a lot more SA, and now the purpose was to prepare Mali's army for a counterterrorism mission. As we will see, what is striking about U.S. SA from this point forward is its narrow focus on tactical issues, force structure, and

\footnotetext{
42 Ahmadou Maiga, "Pourquoi le Gatia?” Le Guido, January 2015, p. 20.

43 Bruce Whitehouse, "How US Military Assistance Failed in Mali," bridgesfrombamako. com, April 21, 2014.

${ }^{44}$ Liane Kennedy-Boudali, The North Africa Project: The Trans-Sahara Counterterrorism Partnership, West Point, N.Y.: U.S. Military Academy, Combatting Terrorism Center, 2007, p. 4.
} 
a relative disregard for such matters as unit cohesion, the integration of ethnic minorities, and morale. U.S. SA did not necessarily do any harm to Mali, but there is no evidence that it helped, either.

The first major U.S. initiative affecting Mali was the Pan-Sahel Initiative (PSI) announced in 2003. PSI was a U.S. Department of State-managed program that employed special forces based in U.S. European Command (USEUCOM). It had a budget of $\$ 7.5$ million over two years, with the first $\$ 6.25$ million allocated for the program's first year. ${ }^{45}$ It focused on developing three light infantry companies in Mali and one each in Mauritania, Chad, and Niger, and instructed them in basic skills such as marksmanship, planning, communications, land navigation, and patrolling. ${ }^{46}$ The United States and the PSI-associated units reportedly took the lead in running to ground Abderrazak al-Para, the commander of the Groupe Salafiste pour la Prédication et le Combat, who, in 2003, orchestrated the kidnapping in Algeria of 32 mostly German tourists. ${ }^{47}$

After PSI, the more ambitious Trans-Saharan Counterterrorism Partnership (TSCTP) came in 2005. The still-ongoing program (Mali was excluded in 2012 because of the coup) began with a budget of $\$ 100$ million a year for five years and included Algeria, Morocco, Nigeria, Senegal, and Tunisia, in addition to the four Sahelian countries involved in PSI. ${ }^{48}$ According to U.S. Government Accountability Office (GAO) studies of TSCTP conducted in 2008 and 2014, the program allocated to Mali $\$ 77.6$ million over the course of fiscal years 2005-2013 (in contrast, over the same time frame, the program allo-

45 Jim Fisher-Thompson, "U.S.-African Partnership Helps Counter Terrorists in Sahel Region,” USEmbassy.gov, March 23, 2004; Kennedy-Boudali, 2007, p. 4.

46 Fisher-Thompson, 2004; Lesley Anne Warner, The Trans Sahara Counter Terrorism Partnership: Building Partner Capacity to Counter Terrorism and Violent Extremism, Alexandria, Va.: CNA, Center for Complex Operations, 2014, p. 22.

47 Fisher-Thompson, 2004.

48 Donna Miles, "New Counterterrorism Initiative to Focus on Saharan Africa," American Forces Information Service, January 15, 2007. 
cated to Chad, Mauritania, and Niger $\$ 45$ million, $\$ 58.5$ million, and $\$ 74.7$ million, respectively). 49

In contrast to PSI, TSCTP was designed to be interagency and reflect a broader approach to security assistance, meaning that, instead of focusing exclusively on counterterrorism-associated military tactics, it included a variety of initiatives run by the U.S. Agency for International Development and other U.S. government agencies intended to boost economic development as well as improve justice provision and security in general. ${ }^{50}$ TSCTP objectives include several categories of engagement: military capacity building, of course, but also "law enforcement anti-terrorism capacity building," "justice sector counterterrorism capacity building," "public diplomacy and information operations," "public diplomacy and information operations," "community engagement," and "vocational training." ${ }_{11}$ The available information does not indicate what proportion of the money spent on Mali went for military assistance compared with the various nonmilitary parts of the program, although one report says it was "more than half." 52

Most of the actual military training work was conducted by special forces elements subordinate to USEUCOM (later U.S. Africa Command [USAFRICOM]) and Special Operations Command, Africa and coordinated by the Joint Special Operations Task ForceTrans Sahara (JSOTF-TS). Those elements were usually organized as Joint Combined Exchange Training teams (JCETs) or Joint Planning and Assistance Teams (JPATs). ${ }^{53}$ JCETs and JPATs made regular rotations through Mali. Until 2012, Mali also participated in TSCTP's signature annual training event, Operation Flintlock, which enabled

49 GAO, Combating Terrorism: Actions Needed to Enhance Implementation of Trans-Sahara Counterterrorism Partnership, Washington, D.C., GAO-08-860, July 2008; GAO, Combating Terrorism: U.S. Efforts in Northwest Africa Would Be Strengthened by Enhanced Program Management, Washington, D.C., GAO-14-518, 2014.

50 Miles, 2007.

51 Warner, 2014, p. 35.

52 Walter Pincus, "Mali Insurgency Followed 10 Years of U.S. Counterterrorism Programs," Washington Post, January 16, 2013.

53 Warner, 2014, p. 29. 
Malian and other TSCTP-participating militaries to work closely with U.S. forces and train on skills deemed relevant for a counterterrorism mission.

The best description of the training furnished to Malian forces by the JCETs and JPATs can be found in Naval Postgraduate School thesis by MAJ Simon Powelson, who was involved in that effort as an Operational Detachment Alpha commander in the 10th Special Forces Group. ${ }^{54}$ According to Powelson, the JCETs' mission was to train up what were to become Mali's elite maneuver units, known as Echelon Tactique Interarmes (Combined Arms Tactical Echelons [ETIAs]), which were roughly company-sized formations of 160 men recruited from various regiments, with complete sets of personal equipment such as uniforms. The JCETs focused almost entirely on providing basic skills and equipment, which they sorely lacked. According to Powelson, because of the Malian army's personnel rotation policies, the JCETs encountered entirely new men each time they had a session with a specific ETIA, meaning that they had to start again from scratch and work on fundamental skills and equipment problems. ${ }^{55}$

The JPATs ran a parallel effort beginning in 2010 out of a desire to improve on the ETIA approach. JSOTF-TS noted that assaulting a terrorist base in the wastes of northern Mali required, among other things, the ability to mount a complex, coordinated attack involving indirect fire synchronized with mounted and dismounted fire and maneuver. The ETIA training program clearly would not yield such a capability. What might, however, was an enduring training relationship between JPATs and a standing Malian unit that would enable that unit to build on its skills and increase its capabilities accumulatively rather than start again from scratch with each rotation.

JSOTF-TS and the Malian Ministry of Defense agreed to focus on the $33^{\mathrm{e}}$ Régiment de Commandos Parachutistes (RCP), the socalled red berets, who were favorites of Mali's president. ${ }^{56}$ The idea evolved until it was agreed that, within the $33^{\mathrm{e}} \mathrm{RCP}$, Mali would build

\footnotetext{
54 Powelson, 2013.

55 Powelson, 2013, p. 20.

56 Powelson, 2013, p. 34.
} 
with U.S. help a company-sized Compagnie Forces Spéciales (CFS) intended to be the core of a future rapid-reaction battalion. ${ }^{57}$ Powelson describes how the JPAT's efforts with the CFS developed a three-tiered approach, with some training provided separately to lower enlisted soldiers, NCOs, and officers, with the purpose of developing their particular skills with respect to their rank and responsibilities. NCOs, for example, were cultivated as trainers. ${ }^{58}$ Indications of progress were evident already in 2011. Officers and NCOs, according to Powelson, began exhibiting the kinds of leadership skills and capabilities "recognizable to U.S. Army NCOs." Moreover, Flintlock 2011, the Malian contingent, which, in 2010, scored "at the bottom of the regional pack," were now "top performers."

When the rebellion started in January 2012, Bamako deployed the ETIAs with the CFS. The CFS did relatively well, although its ability to accomplish anything substantial was severely limited by the inability of the FAMa to sustain it in the field and coordinate with it: One good unit cannot win a war, especially if the rest of the force cannot or will not perform at a required level. The ETIAs, however, disintegrated. Many of their men deserted or even defected, with their equipment-much of it U.S. supplied-passing to the enemy.

\section{Roots of Failure}

The single biggest reason for the units' collapse was the presence of Arab and Tuareg soldiers who quit the ranks. As we discussed, the Malians themselves had no policy with regard to vetting the former rebels or integrating them into the force. U.S. trainers also paid no attention to the ETIA soldiers' backgrounds and made no effort to encourage the Arab and Tuareg recruits to identify with one another regardless of their clan, ethnic, or tribal solidarities, and with the army. ${ }^{59}$ According to a special operation forces (SOF) commander interviewed for this

\footnotetext{
57 Powelson, 2013, p. 35.

58 Powelson, 2013, p. 40.

59 Interview with senior FAMa special forces battalion officer, Bamako, January 22, 2015.
} 
report, SOF paid little attention to developing unit cohesion or esprit de corps; their focus was on tactics. ${ }^{60}$ At the very least, there was a need to attend to unit morale: As the SOF commander put it, the ETIAs were sent north to fight an enemy that was at least as well-trained and equipped but which had a vastly greater sense of purpose. The commander suggested that U.S. SOF may not be best suited for attending to matters such as morale and unit cohesion, for SOF tend to default to a focus on tactical skills. U.S. regular army forces, he argued, would be a better match for this task, with the regionally aligned forces in particular being the obvious choice.

Then-commander of USAFRICOM GEN Carter Ham corroborated to some extent this view in January 2013 when he told a Washington, D.C., audience that U.S. forces involved in training Malians troops (who were among the units that deserted en masse) failed to train them in "values, ethics and a military ethos." 61 According to Ham, the United States focused "almost exclusively on tactical or technical matters," and not enough was done to convince Malian recruits that "when you put on the uniform of your nation, you accept the responsibility to defend and protect that nation, to abide by the legitimate civilian authority that has been established, to conduct yourselves according to the rule of law." 62

Related to the problem of the desertions is the problem of Mali's record of military coups d'état. On three separate occasions-1968, 1991, and 2012 - Malian army officers overthrew the sitting head of state. In 1968, a clique of officers led by Lieutenant Moussa Traoré toppled the country's postindependence civilian leadership under Modibo Keita and installed a military junta that nonetheless continued the practice of distrusting the military and weakening it. In 1991, soldiers, after first firing on protestors at the regime's orders, turned on Traoré and toppled him. The new coup at least heralded the return of

\footnotetext{
60 Telephone interview with SOF commander, July 15, 2015.

61 "Mali Crisis: U.S. Admits Mistakes in Training Local Troops," BBC News, January 25, 2013.

62 Tyrone C. Marshall, Jr., "AFRICOM Commander Addresses Concerns, Potential Solutions in Mali," American Foreign Press Service, January 24, 2013.
} 
multiparty elections and the rise to power of a civilian, Alpha Oumar Konaré (president, 1992-2002). Konaré's successor, Colonel Amadou Toumani Touré, however, was the man who had arrested Traoré in 1991. Touré in March 2012 was deposed in turn by Captain Amadou Sanago. Soon after, Sanago ceded power to a transitional government, and Mali held elections in 2013 that restored constitutional rule; Sanago, since promoted to the rank of general, now sits in jail because of his involvement in the kidnapping and murder in 2012 of rival soldiers following a failed countercoup by members of the $33^{\mathrm{e}} \mathrm{RCP}$.

One striking aspect of these coups is the relative ease with which they have taken place. Traoré and Sanago were low-ranking officers with relatively few followers; resistance to all three coups was light and disorganized. The implication is that Mali's military was at least indifferent to what some members of the service were doing. Mali's soldiers were not necessarily partisan, but they also were not sufficiently interested in defending the constitutional order to stand in the way of the small number of putschists who were. That said, Mariko asserts that everyone welcomed Keita's toppling in 1968, and few were sorry to see Traoré go. Many, in fact, tried to push Traoré out: There was a succession of coup plots, all of which contributed to poisoning the atmosphere in the army and arguably distracted its officers from focusing on their duties.

The FAMa's low morale, abuse of northern populations, failure to integrate northern fighters, and its historical respect for the constitutional order speak to a number of failures. Moreover, the available evidence suggests that the security assistance provided to Mali focused their attentions elsewhere: French and Soviet assistance focused on conventional capabilities; U.S. assistance after $9 / 11$ focused on generating units and preparing them for a counterterrorism mission, narrowly defined in terms of offensive military operations.

\section{Civic Education and Identity Formation}

As mentioned before, southern Malians possess a strong national identity. Indeed, Mali, unlike many postcolonial states-Nigeria among 
them-is not a complete fabrication and benefits from a historical memory featuring great heroes and historical polities as well as a rough congruence between borders and a cluster of ethnic groups. One particular group is dominant, but otherwise most of the rest generally get along, and by all measures appear content to share a destiny.

What's striking in this regard is how little the Malians appear to be concerned about fostering the "right" kind of national identity and taking advantage of its own elasticity. The FAMa in particular clearly take civic education for granted. Malian officers, when asked, indicated that the FAMa did not bother to provide civic education in any meaningful way because they assumed that FAMa recruits received it in school before joining the military. Given the generally poor quality of Malian education and the low level of academic achievement among Malian soldiers in particular (on paper, they all have at least a middleschool education, but it is doubtful the military enforces that requirement), making any assumptions about Malian recruits' education seems reckless. There is also an interesting comparison between the FAMa and the 1950s French army's approach to indoctrination: France not only tried to instill among its colonial troops a degree of identification with France, it taught the troops French and also schooled them in a code of conduct. Mariko, for example, describes how, after his unit went through a training unit on the code of conduct, the French commanders took the time to talk to the recruits and, using Bambara translators, discuss with them what they had retained. The FAMa does not appear to engage in such efforts. An official code of conduct published by the Malian Etat-Major exists, but it is a difficult text with 36 articles that reportedly are unknown to most in the military. ${ }^{63}$

The lack of education is particularly apparent among the FAMa's officers and noncommissioned officers, who, by all accounts, receive very little training of any kind, and at best nominal training in anything related to civil education such as rule of law or the law of war. The FAMa’s leaders appear to bring to their job little insight about how

63 Ministère de la Défense et des Anciens Combatants, "Code de conduite des forces armées et de sécurité du Mali," Bamako, Mali: Ministère de la Défense et des Anciens Combatants, January 10, 1997. 
to behave or the kind of behavior to instill among their subordinates. On paper, there is at least one instrument in place to help keep the army in check: Members of the paramilitary Gendarmerie Nationale (GN), which has a military police function, among others, are supposed to accompany army units whenever they deploy and have the power to place charges against army officers and soldiers. Army and GN leaders interviewed for other RAND studies insisted GN personnel do in fact escort army detachments. ${ }^{64}$ However, there is little evidence that they are of any value, given reports regarding the general state of impunity in the force and the absence of a meaningful justice system, not to speak of a military justice system. The state of Mali currently lacks the ability to prosecute human rights cases, for example. ${ }^{65}$ Moreover, it appears implausible that GN officers would be adequately trained to fulfill the function assigned to them (although GN members on average reportedly are better educated than army personnel), and even less plausible that they would enjoy the kind of institutional support that would empower them to denounce their army colleagues or check them in the field.

\section{Conclusion}

In the course of 2012, it became apparent that the FAMa had three basic problems. One is its fecklessness and lack of cohesion: its inability to protect the country, provide security, and generate confidence in the stage. The second is its lack of respect for civilian authority, as demonstrated by the 2012 coup and the lack of resistance to it. The third is that its presence is often negative in that it not only cannot defeat militants but also antagonizes the very people who might benefit from its protection. To put the matter in the simplest terms, the Malian

\footnotetext{
${ }^{64}$ For example, see interview with Gendarmerie National lieutenant colonel, Bamako, January 23, 2015; interview with Gendarmerie National colonel, Bamako, January 23, 2015; interview with Malian FAMa and Gendarmerie Nationale officers, Gao, January 21, 2015.

65 For Mali's inability to prosecute human rights cases, see Marshall Jr., 2013; Virginie Ladisch, Possibilities and Challenges for Transitional Justice in Mali, New York: International Center for Transitional Justice, 2014.
} 
army must become cohesive and learn to fight, but also to cease being a menace to Malian society and to become, instead, a unifying force.

Both problems point to the need for Mali's army to become more civic, or républicain, which would involve reforming its relationship with Mali's population and ideally make it a more cohesive force, or at least one that is more effective when operating in the north. Malians and FAMa watchers appear to agree. For example, an Arab leader interviewed in Bamako asserted that

[t] he question of the army is very important for us. The army has to be interethnic, diverse. It must be républicain ... for us, for the army to be strong, it has to be, fundamentally, a certain kind of army. Multiethnic and above divisions. ${ }^{66}$

A very different observer, a Western European military intelligence officer working with MINUSMA, made more or less the same observation:

Ethnically, it's challenging for FAMa to project [north] ... maybe in the future if we had better representation of all ethnic groups in the government. FAMa is not well received. Their presence generates aggression. ${ }^{67}$

Of course, making Mali's army more beneficial for nation-building and state legitimacy involves more than just getting the demographics right. One has to cultivate a specific unifying identity or set of values. As a Berabiche notable put it:

The integration of combatants was a good thing. It allowed some representation of the north in the army. Mali was never a nation. We never built a nation, in which those from Kaye and from Kidal share the same values. Young northerners aren't interested in politics; politics never interested them. ${ }^{68}$

\footnotetext{
66 Interview with Arab leader, Bamako, October 11, 2013.

67 Interview with Dutch special forces commander, Bamako, January 16, 2015.

68 Interview with Berabiche leader, Bamako, October 2013.
} 
Some within Mali's military understand this up to a point. For example, one officer who noted that the army needed to recruit more northerners said that they presently rely on Tuaregs from a specific subgroup, the same one associated with a pro-Bamako militia that, among other acts, has been attacking other Tuareg groups and committing abuses against various communities. ${ }^{69}$ It is not clear if he or other Malian military leaders are aware of or concerned with the implications of associating Mali's security services with a particular northern community, one that is, moreover, at odds with other northern communities. Recruiting Tuaregs enhances the FAMa's capabilities; recruiting only Tuaregs from a specific community, one that happens to be in conflict with others, is likely to be counterproductive because it antagonizes other communities and associates Bamako with the interests of the one community at others' expense. Another officer articulated a particularly comprehensive vision of what Mali needed to do to prevail. First, he explicitly argued that Mali needed a républicain army, which he defined as follows:

1. does not do coups d'état, has a clear hierarchy, and is subordinate to civilian authority; should have a culture in which officers know that they are there to serve the politicians and not make policy

2. acts within a legal and social normative framework, in which everyone involved understands that they are individually responsible

3. respects the other institutions of the republic

4. exists to propagate democracy and the republic and is at the service of the citizens. ${ }^{70}$

The idea of making the army more républicain speaks to the realization that the army and Mali's other security services often fall short with respect to such matters as rule of law and human rights, especially in the north; moreover, it also speaks to an awareness of the military's

69 Interview with Malian general officer, Bamako, January 22, 2015.

70 Interview with Malian general officer, Bamako, January 22, 2015. 
usually antagonistic relationship with northerners, many of whom are likely to regard the FAMa as a foreign force that generates insecurity rather than provides security. In effect, the army's inability to operate successfully in the north and create security arguably has at least as much to do with its comportment and relations with northern minorities as it does with the military's strictly operational capabilities. Nevertheless, the same officer and others interviewed also made clear that, at the end of the day, their strategy for dealing with Mali's security problems consisted of two things: (1) acquiring as quickly as possible an offensive military capability and (2) relying on Arab and Tuareg proxy militias.

Mali's partners, it should be noted, are not rushing to fill the gap and contribute little to civic education. Beginning in 2013, the European Union Training Mission in Mali (EUTM) has assumed the primary responsibility for improving Mali's army units by cycling battalions through its facilities. EUTM does include some civic education in its training program, including a law of war unit, but, by the admission of EUTM officers interviewed in January 2015, they do not provide anything beyond the most cursory instruction. "We don't emphasize it because it's not our priority." 71

A final consideration has to do with the role of Malian leadership. Some Mali leaders evoke the need for a républicain force and focusing on ways to win over the northern population. That point of view has yet to inform Malian priorities, however, suggesting that, at the highest level, one still finds a lack of appreciation for what stabilizing the north might require. A case in point is the disastrous attempt in May 2014 by Mali's army to seize the rebel-controlled town of Kidal, an effort that bore all the hallmarks of haste and a striking absence of strategic awareness. In the judgment of French defense analyst Laurent Touchard,

To retake Kidal without the "materials" required to provide for the daily life and security of the local population, without viable projects for the nomadic communities, without ensuring the pro-

71 Interview with EUTM officers, Bamako, January 30, 2015. 
tection of human rights, is to put the plow before the oxen without having oxen. On the contrary, if Bamako wanted to sow the seeds of an umpteenth Tuareg rebellion, well, this is a good way to go about it. ${ }^{72}$

${ }^{72}$ Laurent Touchard, "Décryptage: Paris—Bamako, je t'aime, moi non plus," conops-mil. blogspot.com, June 8, 2013a. 


\section{The Nigerian Army}

It is often said that Nigeria's existence depends on the balance between centripetal and centrifugal forces. In this context, Nigeria's army-one of the strongest and most important actors in Nigerian politics as well as a key pillar of the central government-has played a critical role. ${ }^{1}$ As we will discuss in this chapter, the Nigerian army's record is mixed. It has acted alternatively as a source of stability and of instability and as a generator of state legitimacy and illegitimacy. Its record of coups and imposing its rule is particularly striking. As Table 7.1 shows, Nigeria has been ruled by no less than eight generals, and all but one gained power by overthrowing either a civilian government or another general. The exception, General Abdulsalami Abubakar, rose to power after his predecessor died in office.

The Nigerian army clearly has played a critical role with respect to Nigeria's viability as a nation and the legitimacy of the Nigerian state. For most, that role has been negative. For example, one scholar, writing in 2001, just after the last transition from military to civilian rule, observed that the military at that point had dominated postindependent Nigeria in the political arena and was "largely responsible for the present political, economic and social underdevelopment of the

\footnotetext{
1 U.S. SA to Nigeria's military has been relatively minimal and since the Clinton Administration has focused almost exclusively on Foreign Military Sales and IMET. There has also been modest funding through the Trans-Sahel Counter-Terrorism Project, the Anti-Terrorism Assistance program, and State's International Narcotics Control and Law Enforcement program. For more information, see African Security Research Project, "U.S. Military Involvement in Nigeria," concernedafricascholars.org, September 2009; Defense Security Cooperation Agency, 2014.
} 
Table 7.1

Nigeria's Military Rulers

\begin{tabular}{|c|c|c|c|c|}
\hline Name of Ruler & $\begin{array}{l}\text { Period of } \\
\text { Rule }\end{array}$ & Region & Tribe & Duration \\
\hline General Aguiyi Ironsi & 1966 & South East & Igbo & 6 months \\
\hline $\begin{array}{l}\text { General Yakubu } \\
\text { Gowon }\end{array}$ & $1966-1975$ & North Central & Luri & 9 years \\
\hline $\begin{array}{l}\text { General Murtala } \\
\text { Muhammed }\end{array}$ & 1975-1976 & North East & Hausa & 7 months \\
\hline $\begin{array}{l}\text { General Olusegun } \\
\text { Obasanjo }\end{array}$ & 1976-1979 & South West & Yoruba & 3 years \\
\hline $\begin{array}{l}\text { General Muhammadu } \\
\text { Buhari }\end{array}$ & $1983-1985$ & North West & Hausa/Fulani & 2 years \\
\hline $\begin{array}{l}\text { General Ibrahim } \\
\text { Babangida }\end{array}$ & 1985-1993 & North Central & Hausa/Fulani & 8 years \\
\hline General Sanni Abacha & 1993-1998 & North East & Kanuri & 5 years \\
\hline $\begin{array}{l}\text { General Abdulsalami } \\
\text { Abubakar }\end{array}$ & 1999 & North Central & Gwari & 11 months \\
\hline
\end{tabular}

SOURCE: Antigha Okon Bassey, "The Making of Nigeria as a Sovereign State: A Theoretical Prognosis and Analysis of a Balanced Federalism," GEOGRAFIA Online Malaysian Journal of Society and Space, Vol. 10, No. 2, 2014, p. 39.

nation." 2 This writer argued that it had blocked the country's political development largely by denying the nation's people the opportunity to figure out how to share power and make Nigeria work.

While this assessment might be correct, what matters for this report is the fact of the military's importance for the fate of the Nigerian nation. That importance, it must be stressed, generally has not been related, at least not directly, to the army's capacity to address internal or external security threats. What has mattered most is the Nigerian army's contribution to nation-building. Of course, the rise of a serious insurgency in northern Nigeria, Boko Haram, ties together the issue of state legitimacy and operational effectiveness in that a defi-

2 Edlyne E. Anugwom, "The Military, Ethnicity and Democracy in Nigeria," Journal of Social Development in Africa, Vol. 16, No. 2, 2001, p. 99. 
cit of legitimacy and the comportment of the military have fueled the insurgency, making it a significant challenge vis-à-vis the force's capabilities, which are lacking in many regards.

\section{A History of Division}

Nigeria is a classic example of a nation created out of whole cloth by a colonial power. It exists because Britain in 1914 decided to combine three separate colonies_-each already containing an astonishing

\section{Figure 7.1}

Nigerian Linguistic Groups

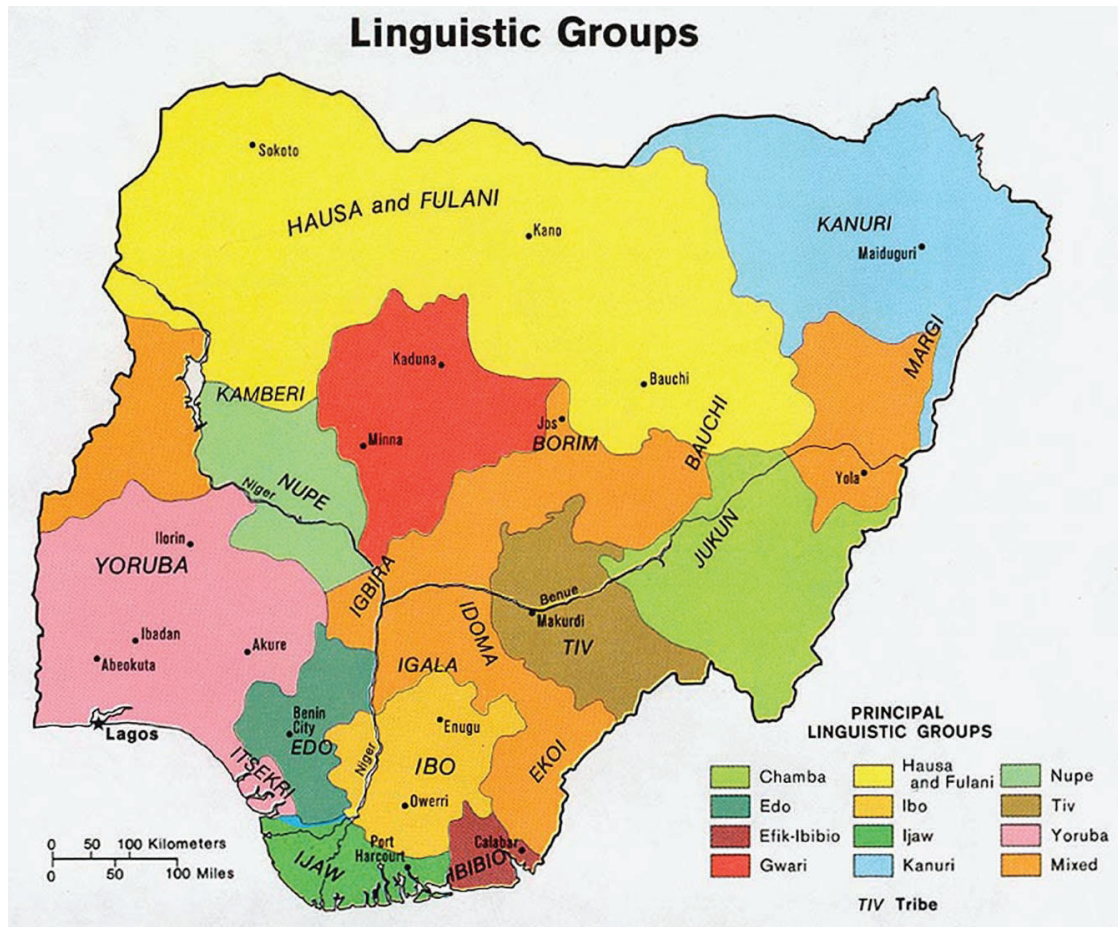

SOURCE: The U.S. Central Intelligence Agency, via the Perry-Castañeda Library Map Collection at the University of Texas at Austin. 
variety of peoples and cultures — into a single administrative unit. The result, upon independence in 1960, was a country with 374 ethnic groups and 400 distinct languages, along with diverse systems of belief, customs, and institutions (Figure 7.1). ${ }^{3}$ There is, moreover, a basic division between the majority-Muslim northern half of the country and the majority Christian south. To make matters worse, British policy was to govern indirectly, which meant that they preferred to govern through local leaders and local institutions, effectively preserving the country's diversity and reducing the potentially integrative effects of interacting with the colonial power, submitting to its authority, and being administered by its officers.

It followed that Nigerian nationalists in the 1940s and 1950s, rather than strive for a "national" identity and "national unity," tended toward regional- and ethnicity-based movements. The British, working together with Nigerian leaders, developed a constitution promulgated in 1954 that intentionally took Nigeria's diversity into account by standing up a federal system in which the powers of the central state were balanced against those of three relatively autonomous regions, each dominated by one of Nigeria's three most prominent ethnic groups: the Hausa-Fulani in the north, the Yoruba in the west, and the Igbo (alternatively spelled Ibo) in the east. ${ }^{4}$

According to historians Toyin Falola and Matthew Heaton, the decision, ostensibly a bow to reality intended to promote equity, had the adverse effect of reifying the country's divisions by reinforcing regional differences and institutionalizing ethnic politics. 5 The Hausa-Fulani, Yoruba, and Igbo fixated on obtaining regional power as the best way to wield national power; minorities in the three regions found themselves alienated from the entire political process. Ultimately, Falola and Heaton write, "there seemed to be very little to gain in domestic poli-

\footnotetext{
3 Antigha Okon Bassey, "The Making of Nigeria as a Sovereign State: A Theoretical Prognosis and Analysis of a Balanced Federalism," GEOGRAFIA Online Malaysian Journal of Society and Space, Vol. 10, No. 2, 2014, p. 37.

4 Toyin Falola and Matthew M. Heaton, A History of Nigeria, Cambridge: Cambridge University Press, 2008, p. 149.

5 Falola and Heaton, 2008, pp. 150-153.
} 
tics from identifying on a national level," and, as a result, when the country became independent in 1960, it was in many ways "a state without a nation." With independence, matters got worse, as everyone grew to fear domination by other groups and regions while also seeing the federal government as dysfunctional.

These trends continued through the 1960s, when fear of domination "clouded any sense of national unity" and each region feared that other regions intended to use the political system to enrich themselves at the expense of their fellow Nigerians elsewhere. According to Falola and Heaton, it then "became imperative for parties once in power to stay in power and for those out of power either to ally with the majority power or to wrest control of the government away from that party in the next election, as opposition parties faced the prospect of perennial marginalization." ${ }^{\circ}$

Discontent and a variety of factors in 1966 prompted Nigeria's first coup, which achieved little beyond removing many of the country's regional and federal leaders. ${ }^{7}$ Power quickly devolved to the commander of the army, Major General John Aguiyi-Ironsi, who went about restoring order. His agenda included eradicating regionalism and tribalism and ending corruption. Ironsi's regime was initially welcomed, especially in the south, but his actions fueled fears among northerners that he represented an Igbo conspiracy. He allegedly favored Igbo officers, for example, but worst of all, he abolished the federal system and replaced it with a unitary system, which, in the eyes of Nigeria's regions, made the central government (including the military and the civil service) appear to be a threat to their own people and prerogatives and a tool to be used by another community to dominate at the others' expense. ${ }^{8}$ For example, the centralization of the power meant that northerners now faced the prospect of being occupied by southern military officers and of being administered by southern civil servants. ${ }^{9}$

\footnotetext{
6 Falola and Heaton, 2008, p. 165.

7 Falola and Heaton, 2008, p. 172.

8 Falola and Heaton, 2008, p. 173.

9 Falola and Heaton, 2008, p. 174.
} 
In response, a group of northern NCOs and officers carried out a countercoup, killing Ironsi. The leading officers then appointed Lieutenant Colonel Yakubu Gowon head of state. Gowon reinstated the regional governments, but he failed to reassure Igbos of the ability and willingness of the Nigerian military to protect them. Massacres of Igbos and other easterners living in the north, often at the hands of northern soldiers, took place with impunity. These sparked retaliatory violence toward northerners in the east. Eastern leader Lieutenant Colonel Ojukwu, the military governor of the eastern region, increasingly felt that Igbo safety was incompatible with a federal Nigeria. He urged easterners to return home and suggested northerners in the east leave, prompting large population movements in the latter half of 1966 and the beginning of 1967. There were negotiations between Ojukwu and Gowon, which broke down in May 1967, leading to war between the federal government of Nigeria and the self-declared sovereign nation of Biafra. ${ }^{10}$

The Nigerian Civil War, often referred to as the Biafran War, killed between one and three million Nigerians, many through starvation. ${ }^{11}$ The government's victory over the Igbo preserved the country, although, ever since it has been riven by further ethnic and regional disputes that, though falling short of a new civil war, have often resulted in violence as well as fostered a political climate in which all parties appear to regard themselves as engaged in a zero-sum contest for power and resources. Governments invariably struggle—and fail—-to balance competing interests and at least appear equitable.

\section{The Military and Nation-Building}

Against this backdrop of internal strife, a number of actors have worked to foster unity. Much of the effort has been cultural and intellectual. Examples include Nigeria's writers and dramatists, chief among them Chinua Achebe and Nobel Laureate Wole Soyinka, as well as academ-

\footnotetext{
10 Falola and Heaton, 2008, p. 175.

11 Falola and Heaton, 2008, p. 180.
} 
ics in the country's universities, artists, and sculptors. ${ }^{12}$ Schools, of course, have played an important role. During the 1960s, according to Falola and Heaton, the school system "became a key sector of Nigerian society in which attempts were made to foster national culture and identity." 13 The schools taught English, which could help unify most Nigerians around a shared lingua franca, and beginning in 1969 developed a primary school curriculum intended to foster national unity and "develop in children a positive attitude to citizenship and a desire in them to make a positive personal contribution to the creation of a united Nigeria." 14 The new universities in particular contributed to national unity by equalizing access to higher education at least by region. ${ }^{15}$ Nonetheless, the military has been the single most important Nigerian institution to play a consistent and active role in nation-building.

\section{Dedication to Nation-Building}

Beginning in 1958, when the Nigerian regiment within the British colonial forces was transferred to Nigerian control, the Nigerian army saw itself and was viewed by others as the "vanguard" of national integration and "Nigerianism." According to Gaub, military personnel in Nigeria, whether in the army itself or in the successive military governments, had a clearly integrative vision of the country and initiated political measures accordingly once they had the opportunity. This self-identity arguably grew as a result of the civil war, when the army, which had saved federal Nigeria, took it on itself to foster further integration. As we will see, the army's embrace of its nation-building mission was at times a double-edged sword in that it encouraged its officers to overthrow civilian governments and one another. Moreover, the army's own abuses had the negative effect of undermining state legitimacy notwithstanding its commitment to the contrary.

\footnotetext{
12 Falola and Heaton, 2008, pp. 160-162.

13 Falola and Heaton, 2008, p. 162.

14 Bassey, 2014, p. 37.

15 Falola and Heaton, 2008, p. 162.
} 
Of interest to us are three aspects of the Nigerian army's nationbuilding mission. The first is its concern for social integration within the ranks and its management of ethnic and regional diversity. The second is its concern for integrating Nigerians in the larger society. The Nigerian army took seriously the modernization theorists' argument that an army can be a socializing force that will eradicate ethnic and regional solidarities and create a new, national citizen. ${ }^{16}$ The third is its political comportment, which at times translated into positive efforts to enhance unity and strengthen governance while, at others, undermined governance and, ultimately, legitimacy.

\section{Building Internal Cohesion}

The roots of Nigeria's military culture and much of its nationalism lay, as is often the case in former colonies, in the experience of Nigerian soldiers during World War II. Prior to the war, the British practice was to recruit monoethnic units, and they had an explicit preference for recruiting among the Hausa. Wartime requirements, however, obliged Britain to cast a larger net and form integrated units. For the first time, according to Gaub, men who had never travelled within Nigeria met men from other parts of the country and began to think of themselves as Nigerian. ${ }^{17}$ Moreover, whereas Hausa was the official language of the colonial force, English increasingly replaced it at least in practice and facilitated interethnic cooperation, just as the spread of English generally among the Nigerian population did much to foster ties.

After independence, the new Nigerian army adopted English as its official language and continued to follow the wartime British model not just of integrating units but also of fostering a professional ethos in which the military became a "total" experience and replaced previous ties, especially among officers who, according to Gaub, preferred to identify themselves as officers and gentlemen. ${ }^{18}$ From 1961 onwards, according to Gaub, mixed units were mandatory explicitly because of

\footnotetext{
16 Falola and Heaton, 2008, p. 159.

17 Florence Gaub, Military Integration after Civil Wars: Multiethnic Armies, Identity and Post-Conflict Reconstruction, Abingdon, Oxon: Routledge, 2010, p. 39.

18 Gaub, 2010, p. 40.
} 
the desire to enhance the army's corporate spirit. ${ }^{19}$ From that moment, the army paradoxically refused to recognize ethnicity while at the same time clearly, if not always explicitly, devised strategies for coping with ethnic diversity, usually by trying to strike appropriate ethnic balances while also hoping to dissolve ethnic divisions.

The idea of being above ethnicity became particularly important for the officers, who developed a strong corporate identity according to which professionalism equals modernity, which equals transcending ethnic and regional solidarities in favor of becoming new Nigerian citizens. It helped that theirs was a relatively egalitarian and meritocratic institution; despite their different backgrounds, they generally had a common education (especially the relatively large portion who studied at Sandhurst) and were required to live in military housing. As for the army at large, from the beginning it operated at least a de facto system of regional (and thereby ethnic) balancing, mandated mixed units, and had a policy of rotating units around the country so that they would both come to represent and in fact be something new, different, and national. ${ }^{20}$

Of course, all was not entirely well with either Nigeria or the Nigerian army, and a host of problems and missteps combined to pull the country and, to some extent, the military, toward greater discord. For one, the recruitment of southerners spelled an end to the Hausa's near monopoly over the military under the British; the newcomers, foremost among them the Igbo, were conscious of the fact that joining the army was a way to obtain greater power in general. Moreover, in part because of the southerners' generally superior educational levels, Igbos rose quickly through the ranks and became disproportionately overrepresented in higher positions (or at least appeared to be overrepresented). When, in 1966, a number of officers overthrew the republic in the name of national unity, the coup smacked of an Igbo conspiracy. In a sense, Nigerian officers were so convinced of their own nonethnicity that they had a tin ear and unwittingly set in motion a number of developments that at least precipitated the civil war.

19 Gaub, 2010, p. 36.

20 Gaub, 2010, pp. 36-37. 
After the war, the military took even more seriously its mission of building the nation both by striving to embody it while also promoting cohesion in Nigerian society at large. Monoethnic units, for example, were formally forbidden. ${ }^{21}$ Crucially, General Gowon consciously chose to deal with the Igbo and former Biafran combatants with magnanimity, a policy that is often compared with Abraham Lincoln's conciliatory approach to the Confederacy after the American Civil War. Many former Nigerian army officers who had defected to the Biafran side were reintegrated into the force or allowed to retire with full benefits. Those who returned to the ranks were enrolled in a "reorientation course" and participated in a "welcome back" ceremony. ${ }^{22}$ Moreover, according to Gaub, the evidence strongly indicates that the Nigerian army had an unspoken policy of encouraging Igbos to join and promoting them through the ranks in an effort to rebuild ethnic balance and reintegrate the Igbo community. ${ }^{23}$ It also upped its rhetoric and symbolism regarding national reconciliation and promoted a discourse of "Nigerianization" that would predominate for years to come, most particularly under Obasanjo. ${ }^{24}$ As Gaub observes, "Obasanjo avoided being defined by his ethnic affiliation and always stressed his village, his négritude, his Nigerian and African identity over his ethnicity, his language, or his state."25

Because of the military's resistance with regard to talking about ethnicity, it has never put in place explicit recruitment policies, although in practice it had a quota system beginning in the early 1960s, and different iterations have been effect ever since. To get around dealing with ethnicity, Nigerian governments have preferred to focus on regional diversity, which amounts to a proxy for ethnic diversity. Thus, for example, Obasanjo ensured that the entrance examination for the Nigerian Defense Academy could be taken in all the state capitals,

\footnotetext{
21 Gaub, 2010, p. 36.

22 Gaub, 2010, pp. 27-28, 38.

23 Gaub, 2010, p. 28.

24 Gaub, 2010, p. 30.

25 Gaub, 2010, p. 30.
} 
and infantrymen were recruited on a state-by-state basis to boost the numbers from underrepresented states. ${ }^{26}$ Thus, by striving to achieve regional balances within units, it is at least indirectly reaching for an ethnic balance.

After the war, leaders of Nigeria's armed forces began to promote the same discourse of Nigerianization regardless of their own personal ethnic affiliation. Gaub observes that part of the success of Gowon and Obasanjo in particular is that they "projected reassuring images to the diverse Nigerian populace," and they insisted in promoting their national and military identities above their ethnic and regional ones. ${ }^{27}$ Gaub cites Gowon as insisting,

I have never been a minority in mind or in concept, I can assure you. I have always thought of Nigeria as a whole. . . . In fact, I hate all this talk of minority versus majority. ${ }^{28}$

Gowon led the way by making a reconciliation and unity a priority. First, as discussed, he encouraged the reintegration of Biafran combatants into the military and Igbo recruitment. Second, he hoped to extend the integrative function of the army to society at large by establishing in 1973 the National Youth Service Corps, which required all university and polytechnic graduates to perform one year of government service after graduation. This was designed to promote national unity by making young Nigerians active participants in the activities of government with the aim of increasing patriotism. It was also supposed to bring together Nigerians from across the country to work together toward common goals. ${ }^{29}$ The Corps' first director, Colonel Ahmadu Ali, explained that "we need urgently to break down the feeling of ethnicity and build in its place the idea of unity — of being Nigerians first and foremost." ${ }^{30}$ He stated elsewhere that this "new breed [of] Nigeri-

\footnotetext{
26 Gaub, 2010, p. 35.

27 Gaub, 2010, p. 30.

28 Gaub, 2010, p. 30.

29 Falola and Heaton, 2008, p. 190.

30 Gaub, 2010, p. 42.
} 
ans ... stripped of colonial mentality ... will be better placed to find the solutions to rural poverty and national integration."31 Gaub summarizes the program's significance as the "cradle of the nation, precisely as the modernization theorists had stated." 32

The program still exists, and today it describes its purpose as emphasizing

[t]he spirit of oneness and brotherhood of all Nigerians, irrespective of cultural or social background. The history of our country since independence has clearly indicated the need for unity amongst all our people, and demonstrated the fact that no cultural or geographical entity can exist in isolation. ${ }^{33}$

Gowon also made a big push to increase the school system's role as a key instrument for building a Nigerian identity. ${ }^{34}$ In 1974, he announced the Universal Primary Education Scheme to help unify the post-civil war country by leveling the educational and cultural differences that were a heritage of the colonial era. ${ }^{35}$ The schools taught English, and the government further developed curriculum designed to foster national identity. It also directed secondary schools to recruit from other areas to become heterogeneous. ${ }^{36}$ Finally, the schools in 1976 introduced a pledge of allegiance to be said each day, and the government also instituted Independence Day (October 1) and National Children's Day (May 27), which featured parades, marches, singing, and sporting events. ${ }^{37}$

31 Adiele Eberechukwu Afigbo, Nigerian History, Politics and Affairs: The Collected Essays of Adiele Afigbo, ed. Toyin Falola, Trenton, N.J.: Africa World Press, 2005, p. 551.

32 Gaub, 2010, p. 42.

33 Gaub, 2010, p. 42.

34 Falola and Heaton, 2008, p. 162.

35 T. M. Bray and G. R. Cooper, "Education and Nation Building in Nigeria Since the Civil War," Comparative Education, Vol. 15, No. 1, March 1979, p. 34.

36 Bray and Cooper, 1979, p. 35.

37 "I pledge to Nigeria my country, To be faithful, loyal and honest, To serve Nigeria with all my strength. To defend her unity/And uphold her honour and glory; So help me God.” 
Other examples of steps taken by the country's military leaders to foster a national identity include Mohammed's decision to move the capital from Legos to Abuja and carving out a Federal Capital Territory, the idea being, in part, to move the capital closer to the north and create a more appropriate center for the federal government. ${ }^{38} \mathrm{He}$ and his immediate successor, Obasanjo, also tried to foster national unity through FESTAC ' 77 , an African arts and culture festival that was intended to showcase the "traditional" cultures of Nigeria and also show Nigeria's wealth and capabilities through the construction of a massive state-of-the-art theater and surrounding housing complex. ${ }^{39}$ The festival gave a pride of place to Nigerian artistic and theatric productions; two large exhibition halls housed Nigerian cultural artifacts and works by contemporary Nigerian artists. ${ }^{40}$ The regimes of Mohammed and Obasanjo later created a registry of national heroes, beginning with the nation's four founding fathers. The aim, according to Abu Bakarr Bah, was to create "a powerful symbol of Nigerian nationhood and provide a leadership reference point for all Nigerians." 41

Lastly, according to Bah, two of Nigeria's post-civil war constitutions took pains to call for cultivating a national identity and national unity:

So urgent is the need for integration that both the 1979 and 1999 Constitutions called upon the Nigerian state to encourage "intermarriage among persons from different places of origin, or different religious, ethnic, or linguistic association or ties" and "the formation of associations that cut across ethnic, linguistic, religious, or other sectional barriers," so as to foster national integration. Indeed the preoccupation with this problem in itself is recognition that Nigeria is still not yet a "united nation." 42

\footnotetext{
38 Falola and Heaton, 2008, p. 190.

39 Falola and Heaton, 2008, pp. 193-194.

40 Falola and Heaton, 2008, p. 194.

41 Abu Bakarr Bah, Breakdown and Reconstitution: Democracy, the Nation-State, and Ethnicity in Nigeria, Oxford: Lexington Books, 2005, p. 90.
}

42 Bah, 2005, p. 69. 
General Muhammadu Buhari (Nigeria's current president) and General Ibrahim Babangida, arguably following Gowon's lead, also attempted to build cohesion by cultivating "a quasi-military ethos within wider society." 33 Buhari established the War Against Indiscipline, which was intended to instill a sense of work ethic, nationalism, discipline, and other desirable traits. Though initially well received, it worked only under the watch of the police state, which grew in size and strength under Buhari. It ultimately failed to address any of Nigeria's real problems. ${ }^{44}$ Babangida is responsible for the mass mobilization for economic recovery, self-reliance, and social justice (MAMSER). MAMSER, according to Falola and Heaton, was created to build support for the democratic transition, educate citizens, and encourage them to vote. ${ }^{45}$ Odd as these programs may sound today, they grew directly out of the same modernist impulse that saw the military as an incubator for wider social and national development and cohesion. While their success was mixed, they are further evidence of the military government's awareness of the need to strengthen national consciousness and the impulse to see martial mobilization and the shared experience of service as opportunities to forge a closer union.

\section{The Double-Edged Sword of Political Engagement}

The obvious problem with the Nigerian military's self-identity as torchbearers of national unity is that it has translated into a propensity to overthrow civilian governments and leaders from its own ranks and appropriate for itself the mantel of power, as Table 7.1 illustrates. According to Anugwom, the argument has even been made that, at least historically, "coup planning and execution" has been seen by the military "as part of the essence of the institution." 46

\footnotetext{
43 Henry A. Dietz, Jerrold Elkin, and Maurice Roumani, eds., Ethnicity, Integration, and the Military, Boulder, Colo.: Westview Press, 1991, p. 197.

${ }^{44}$ Falola and Heaton, 2008, pp. 214-215.

45 Falola and Heaton, 2008, p. 226.

46 Anugwom, 2001, p. 38.
} 
The recruitment of well-educated and highly trained elite corps in the military may have even strengthened this belief since this category of military personnel may see themselves as bearing the responsibility for the corporate survival of the country. As good as this is for morale, it may breed incessant intervention by the army in the democratic process in Nigeria. Thus the "corrective" role of military intervention in Nigeria may continue to mar democratic experiments in the country. What needs to be corrected is the anomalous allocation of this role to itself by the military. The entire populace should be allowed to exercises their civic responsibility of correcting their leaders through the ballot box. ${ }^{47}$

It is clear that the army has at least seen itself as acting to "correct” the Nigerian government's course. Those who overthrew Gowon, for example, and replaced him with General Mohammed, were motivated at least in part by Mohammed's interest in restoring "dignity" to the military and retuning the country to democracy. Gowon's regime by then had sullied itself with corruption that flourished apace with the boom in oil revenue and abuses of power by military officers; the coup was not unpopular. ${ }^{48}$ Obasanjo, who succeeded Mohammed after his assassination, more or less followed Mohammed's policies by seeking to root out corruption, promote national unity, and transition to civilian rule. Obasanjo also expanded the practice begun under Gowon of increasing the number of Nigeria's states. In 1976, Obasanjo added seven new states to the country's existing 12, giving the states new names. The idea was to blur ethnic and geographical lines to the extent that regional origin could no longer be an indicator of ethnic affiliation. ${ }^{49}$

Obasanjo made good on his promise to transition to a civilian regime, but the new Second Republic squandered what good will it enjoyed from the public through massive corruption, repression, and financial mismanagement. This led some in in the military to think

\footnotetext{
47 Anugwom, 2001, p. 38.

48 Falola and Heaton, 2008, pp. 186-188.

49 Gaub, 2010, pp. 30-31.
} 
that their services were once again required. Thus there was another coup. ${ }^{50}$

The generals who governed Nigeria next embodied the problems associated with military rule: They acted to promote unity and get the country back on track, but generally failed to accomplish their goals while, at the same time, undermining the legitimacy of the very state they hoped to promote and the integrity of the military through corruption or abuses of power. The first, Buhari (who was recently elected the country's president), was probably the least corrupt but the most ruthless in his bid to clean up the Nigerian state and society and school the nation in the republican virtues of discipline and lawfulness. ${ }^{51}$ He instituted a police state and spied on his own officers, going after anyone suspected of criminality. ${ }^{52}$ Ultimately, he succeeded only in antagonizing people, and he failed to provide short-term relief to most Nigerians. ${ }^{53}$

Buhari eventually was overthrown in a palace coup organized by Babangida, who promoted a softer approach than Buhari and certainly cut back on repression. ${ }^{54}$ Babangida arguably had bad timing: He oversaw structural adjustment programs mandated by the International Monetary Fund and a number of reforms that caused significant pain in the near term, while struggling in a variety of areas. The economy declined further. According to Falola and Heaton, one of the ways Nigerians dealt with the economic problems of the Babangida period was turn to religion: This was an era in which fundamentalist Islam and charismatic and evangelical Christianity made significant inroads. Nigerian society in general became more religiously (and thus regionally) polarized than ever, and Christian and Muslim identity became significantly more politicized..$^{55}$ Babangida attempted to hold elections

\footnotetext{
50 Falola and Heaton, 2008, p. 208.

51 Falola and Heaton, 2008, p. 212.

52 Falola and Heaton, 2008, pp. 213-214.

53 Falola and Heaton, 2008, p. 215.

54 Falola and Heaton, 2008, p. 217.

55 Falola and Heaton, 2008, pp. 221-222.
} 
and transition to civilian rule. Against a backdrop of spreading anarchy, however, General Sani Abacha in 1993 pushed Babangida aside in a coup. ${ }^{56}$

Abacha proved to be the worst of the worst, a shining example of the corrupting influence of absolute power. He swept away state and national assemblies, banned political parties, and imprisoned and executed rivals and dissenters. He and his family also stole an astonishing $\$ 3$ billion; his governors were similarly corrupt. ${ }^{57}$ After his death in 1998 from "an apparent heart attack," according to Falola and Heaton, General Abdulsalami Abubakar replaced him and led a transitional government that handed power to the winner of an election held in 1999, Obasanjo. ${ }^{58}$

Looking backward, the overall record is poor. Anugwom writes,

The military in Nigeria comes to power with the expressed intention of acting as a corrective regime. It represents itself as having been reluctantly lured into government to help improve the civilian polity and after than hand-over to civilians. But, as Dent argues, only the military regime of Mohammed/Obasanjo can claim to having performed this corrective function. ${ }^{59}$

Moreover, even when the military came to power for the right reasons, "there is always the danger of the corruption of military power." "This form of corruption," Anugwom observes, "usually stems from either the ruling military elite's love of power for power's sake or the love of power for money sake." ${ }^{0}$ Many see money as the primary motivator of political activism.

One might also debate the results of or even the sincerity of the military's stated mission of building an integrated force and contributing to the shaping of a transethnic, national citizenry. Critics such as

\footnotetext{
56 Falola and Heaton, 2008, p. 229.

57 Falola and Heaton, 2008, p. 234.

58 Falola and Heaton, 2008, p. 234.

59 Anugwom, 2001, p. 99.

60 Anugwom, 2001, p. 100.
} 
Anugwom have characterized the army as being "ethnicized and politicized from the beginning." 61 According to her, the military uses ethnicity as a means to perpetuate itself in power and weaken the collective resolve of citizens as well as create conflicts among the political elitesconflicts that give the military a further excuse to usurp power. ${ }^{62}$ "The top hierarchy of the military establishment is structured in such a way that military-cum-political power always lies with a particular ethnoregional group."63 Indeed, another author tallied the duration of rule of each Nigerian leader and noted that, out of the total time spent under military rule (29.2 years), 25.6 years were under northerners, while only 3.6 years were under southerners. ${ }^{64}$ More recently, allegations in the Nigerian press alleged widespread favoritism based on ethnicity (Igbo) and location with respect to promotions. The army was quick to respond, with the chief of staff in 2013 telling reporters that there was no discrimination, and all promotions and other decisions were based on merit. ${ }^{65}$ The promotion board, moreover, had members "drawn from the geo-political and ethnic divides in the country." The chief of staff also insisted that internal army procedures needed to be kept from politics. The army "must be protected" and "issues of ethnoreligious considerations should be down-played." "I want to assure you that the army of today is not the type of Nigeria army that dragged the nation into war in the 60s." 66

\footnotetext{
61 Anugwom, 2001, p. 101.

62 Anugwom, 2001, p. 106.

63 Anugwom, 2001, p. 106.

64 Bassey, 2014, p. 40.

65 “Nigerian Army Denies Lopsidedness in Promotions, Postings, Retirements," Premium Times, January 11, 2013.

66 “Nigerian Army Denies Lopsidedness in Promotions, Postings, Retirements," 2013.
} 


\section{Conclusion}

It appears to be the case that the Nigerian army has not lived up to its own self-image, and the excesses, failures, and general tawdriness of military rule outweigh the army's contributions to the nation. Nonetheless, the army's role, for good or bad, has been significant. It has been supportive of nation-building in some ways, but not in others, and either way the difference matters. Making the army more civic or républicain, as the Malians put it, is critical.

What has not been the case, at least until recently, is that the Nigerian army's capacity to deal with internal and external security threats has mattered, at least not for the government's legitimacy and the country's stability. This admittedly may be because Nigeria since the Biafran War has not been tested. The country has faced no real external security threats, and the unrest and banditry associated with the Niger Delta similarly has threatened the state or its general stability. Boko Haram is different. Now the Nigerian army's ability to conduct stability operations and a counterinsurgency mission is vital, and as we have all learned over the past 15 years, the legitimacy of the state and its security forces are of great importance. Regardless of Boko Haram, however, Nigeria's survival as a nation is far from being assured. The nation is still being built, and the military has a central role in that project. 



\section{Conclusion}

The purpose of this report has been to explore the relationship between armies and nation-building. The argument is that SFA should focus less on technical matters such as force structure or readiness as it is conventionally understood, and more on a force's development within the context of the larger nation-building project, more specifically with respect to the cultivation and promotion of ideas, identities, and ideologies that promote cohesion and the legitimacy of the state or regime. Warfighting capabilities should be understood as necessary but not sufficient to see a client state prevail in the face of a serious challenge, particularly if the challenger offers rival claims to legitimacy and a rival ideology.

In revolutionary, postrevolutionary, and postcolonial states, much of the work of building the nation or winning for one side or another control over the country and, ultimately, legitimacy, has to do with ensuring the victory of one set of ideas over another. Armies have a role to play. Besting the enemy on the battlefield certainly helps, and rare are the governments and regimes that can survive military defeat. But armies also embody and promote specific ideas and help legitimize the state. An army's ideological makeup, moreover, often is not immaterial to how well it fights, its ability to remain cohesive in the face of hardship, and its relations with the civilian population. Revolutionary and counter-revolutionary alike-or insurgent and counterinsurgent alike, if one prefers - have to have a cause worth fighting for. In any case, armies can support nation-building in a variety of ways, of which tac- 
tical capabilities or "readiness" as it is conventionally measured might play only a small role.

In the first three cases, South Korea, South Vietnam, and Iraq, one is struck by the divergent degrees to which the three countries' national leaders were in possession of national ideologies, pursued a coherent nation-building project, and built national armies in a manner that complemented that larger nation-building project. Rhee and his successors arguably represent an extreme case, particularly given their authoritarianism and illiberalism. Nonetheless, they had a clear idea of what they were doing and were keenly interested in developing Korea's armed forces in such a way as to promote their political and ideological objectives while simultaneously pursuing the larger nationbuilding and modernization project by a variety of different means. The ROKA was never just a tool for countering communist troops on the battlefield. It was also a means to counter the communist threat more broadly by promoting South Korea's brand of nationalism and the legitimacy of both the South Korean Republic and the particular regime in charge. While it is difficult to determine the extent to which U.S. SFA helped, it is noteworthy that U.S. SFA, while in fact focusing on the ROKA's force structure and military capabilities, also was attentive to the ROKA's institutional culture, morale, and political orientation.

In comparison, Vietnam's Diem arguably was less effective at nation-building than his Korean peers, and his successors were worse. They were less attentive to developing and promoting a national ideology capable of rivaling the communists' and similarly inattentive to the cultivation of ideology within the military and in support of the military's relationship with the people. On the contrary, the ARVN, because of its rapid growth, appears to have done more to strain ties between the nation and the government than otherwise. The U.S. advisory mission, in contrast to the Korean case, may have made matters worse by encouraging the ARVN's rapid growth and focusing narrowly on force structure and readiness metrics. Iraq provides a similar case: The Iraqi government lacked a clear nation-building vision and an ideology to promote the legitimacy of the new U.S.-created government. It also steered the country toward sectarianism rather than 
seek to build while its U.S. advisors focused on capabilities and force structure.

Our next cases involve postcolonial African states that to varying degrees set about promoting national ideologies and using the military to complement their nation-building efforts. They (along with the Korean example) demonstrate the danger inherent in having militaries play an intrinsically political role, particularly when other state institutions are weak or when ethnic divisions are great. Such divisions by no means preclude nation-building but rather emphasize the importance of having a concerted nation-building effort, with the military acting as a complement to other institutions and actors rather than standing alone. Of particular interest is the fact that all three African states did have founding ideologies shared by at least some members of the political class and general population, and their leaders aspired to cultivate those ideologies and build their nation accordingly (with militaries playing some role). Mali, comparatively speaking, accomplished the least. One reason might be the fact that Mali has always had a strong national identity, encouraging its leaders to take that identity for granted rather than to cultivate it, and they appear to have been (and possibly remain) blind to the fact that Malian identity as they conventionally define it excludes certain minorities. Nigeria, in contrast, had no inherent identity. Its leaders invented one out of whole cloth and took nothing for granted, although they have not matched their ideological work with consistent and effective implementation. The same is true of the Ghanaians, who, like Mali, retained a strong precolonial identity yet, unlike Mali, appears to have been more mindful of the need to work toward inclusivity. Indeed, better leadership is one factor in Ghana's relative success. Another factor is that Ghana only recently began oil production, whereas, in Nigeria, oil wealth clearly had a corrosive effect on the country just as it was beginning to heal after the Biafra War.

With respect to U.S. SC programs (e.g., SA, SFA), the available evidence does not indicate whether they have helped or hindered the three African countries' political development or that of their militaries. It should be noted, however, that, for the most part, U.S. SC has corresponded well with their real requirements, specifically with its 
emphasis on professional education. With the exception of Mali post2001, the United States has not recruited these countries into military efforts, with the result that there has not been an emphasis on force structure, capabilities, or readiness.

This leads to the question of if and how the United States can, through SFA, contribute to nation-building or legitimacy beyond the work it already does to boost host-nation militaries' capabilities. How can the United States work to build civic or républicain armies, particularly when so much depends on the host nation? Indeed, our case studies make clear that critical to the success of a fragile or beleaguered state is the extent to which its leaders are committed nation-builders who are in possession of or are busy elaborating ideologies and narratives that support their side in conflicts with rivals who have competing claims to legitimacy. Of the nations discussed here, South Korea's leadership clearly understood itself to be engaged in a life-or-death struggle not just against an outside military power but also a rival ideological movement that threatened the nation from within. This meant, among other things, dedicated efforts to instill within the military strong cohesion and resolve with respect to South Korea's cause. The United States understood and supported Korean efforts while looking for opportunities to steer the Koreans toward policies and values more in line with U.S. ones. In general, the United States worked to promote greater liberalism and temper the Korean leadership's authoritarianism. In our other cases, there is a range with respect to the extent to which host-nation leaders have engaged in nation-building projects as well as the effectiveness with which they pursue it. Ghanaians and Nigerians might require help with implementation and reinforcement, but they at least have clear ideas about what they should do and how to do it. Building a civic army, a républicain army, or an armée-nation are already features of their national identity and their understanding of the purpose of their militaries. Mali, and perhaps Iraq, require convincing. In those cases, the United States might encourage a shift in attention away from force structure, capabilities, and readiness. More important, the United States might be obliged to recognize the limits of what SFA can do. If a government has little interest in the larger nation-building/legitimacy project, the value of simply providing clas- 
sic SFA designed to boost force structure, capabilities, and readiness should not be overestimated. It might be necessary, but might be far from being sufficient. 



\section{Bibliography}

Abbas, Yasir, and Dan Trombly, "Inside the Collapse of the Iraqi Army's 2nd Division," War on the Rocks, July 1, 2014. As of January 31, 2017:

http://warontherocks.com/2014/07/

inside-the-collapse-of-the-iraqi-armys-2nd-division/

Adekson, J. 'Bayo, “Army in a Multi-Ethnic Society: The Case of Nkrumah's Ghana, 1957-1966," Armed Forces and Society, Vol. 2, No. 2, 1976, pp. 251-272.

Afigbo, Adiele Eberechukwu, Nigerian History, Politics and Affairs: The Collected Essays of Adiele Afigbo, ed. Toyin Falola, Trenton, N.J.: Africa World Press, 2005.

African Security Research Project, "U.S. Military Involvement in Nigeria," concernedafricascholars.org, September 2009. As of January 30, 2017: http://concernedafricascholars.org/african-security-research-project/?p=83

Almaliky, Muhamed H., "Mending Iraq: Can Abadi Bridge the Country's Sectarian Divide?” Foreign Affairs, January 16, 2015. As of January 30, 2017: https://www.foreignaffairs.com/articles/middle-east/2015-01-16/mending-iraq

Anderson, Benedict, Imagined Communities: Reflections on the Origin and Spread of Nationalism, London: Verso, 1991.

Andrade, Dale, "Westmoreland Was Right: Learning the Wrong Lessons from the Vietnam War," Small Wars and Insurgencies, Vol. 19, No. 2, June 2008, pp. 145-1818.

Aning, Kwesi, and Ernest Lartey, Parliamentary Oversight of the Security Sector: Lessons from Ghana, 1995. As of January 30, 2017:

http://www.agora-parl.org/sites/default/files/lessons_from_ghana.pdf

Anode, David, "Photos: Top Town Armed Robbery Victims Call for Joint PoliceMilitary Patrols," myjoyonline.com, February 16, 2015. As of February 7, 2017:

http:/www.myjoyonline.com/news/2015/February-16th/photos-top-town-armedrobbery-victims-call-for-joint-police-military-patrols.php

Anugwom, Edlyne E., "The Military, Ethnicity and Democracy in Nigeria," Journal of Social Development in Africa, Vol. 16, No. 2, 2001, pp. 93-114. 
Anyidoho, Akosua, and M. E. Kropp Dakubu, "Ghana: Indigenous Languages, English, and an Emerging National Identity," in Andrew Simpson, ed., Language and National Identity in Africa, Oxford: Oxford University Press, 2008, pp. 141-157.

Arango, Tim, "In Struggle for National Identity, Iraqis Rally Around Many Flags," New York Times, December 22, 2014a. As of January 30, 2017: https://www.nytimes.com/2014/12/23/world/middleeast/iraqis-rally-around-manyflags-as-a-national-identity-falters.html

"U.S. Troops, Back in Iraq, Train a Force to Fight ISIS," New York Times, December 31, 2014b. As of January 30, 2017:

https:/www.nytimes.com/2014/12/31/world/us-troops-back-in-iraq-train-a-forceto-fight-isis.html

Bah, Abu Bakarr, Breakdown and Reconstitution: Democracy, the Nation-State, and Ethnicity in Nigeria, Oxford: Lexington Books, 2005.

Bassey, Antigha Okon, "The Making of Nigeria as a Sovereign State: A Theoretical Prognosis and Analysis of a Balanced Federalism," GEOGRAFIA Online Malaysian Journal of Society and Space, Vol. 10, No. 2, 2014, pp. 34-45. As of January 30, 2017:

http://www.ukm.my/geografia/images/upload/3.geografia-april 2014-bassey-bi1edam.pdf

Beehner, Lionel, Shiite Militias and Iraq's Security Forces, Washington, D.C.: Council on Foreign Relations, November 30, 2005. As of January 30, 2017: http://www.cfr.org/iraq/shiite-militias-iraqs-security-forces/p9316

Bensahel, Nora, Olga Oliker, Keith Crane, Rick Brennan, Heather S. Gregg, Thomas Sullivan, and Andrew Rathmell, After Saddam: Prewar Planning and the Occupation of Iraq, Santa Monica, Calif.: RAND Corporation, MG-642-A, 2008. As of December 12, 2016:

http://www.rand.org/pubs/monographs/MG642.html

Bertaud, Jean-Paul, Valmy: La Démocratie en Armes, Paris: Gallimard, 1970.

—, La Révolution Armée: Les Soldats-citoyens et la Révolution Française, Paris: Éditions Robert Laffont, 1979.

Blaydes, Lisa, "Iraqi Nationalism and the Iran-Iraq War," promeps.org (Project on Middle East Political Science), March 10, 2015. As of November 2, 2015: http://pomeps.org/2015/03/10/iraqi-nationalism-and-the-iran-iraq-war/

Boilley, Pierre, Les Touaregs Kel Adagh: Dépendances et révoltes: du Soudan français au Mali contemporain, Paris: Karthala, 1999.

Bradley, Matt, “Iraq Crisis: Nouri al-Maliki Quits,” Wall Street Journal, August 15, 2014. As of March 6, 2015:

http://www.wsj.com/articles/iraqi-prime-minister-steps-down-1408047116 
Bray, T. M., and G. R. Cooper, "Education and Nation Building in Nigeria Since the Civil War," Comparative Education, Vol. 15, No. 1, March 1979, pp. 33-41.

Brazinsky, Gregg A., Nation Building in South Korea: Koreans, Americans, and the Making of a Democracy, Chapel Hill: University of North Carolina Press, 2007.

Bremer III, L. Paul, "How I Didn't Dismantle Iraq's Army,” New York Times, September 6, 2007. As of January 31, 2017:

http://www.nytimes.com/2007/09/06/opinion/06bremer.html

Brennan, Rick, Charles P. Ries, Larry Hanauer, Ben Connable, Terrence Kelly, Michael J. McNerney, Stephanie Young, Jason H. Campbell, and K. Scott McMahon, Ending the U.S. War in Iraq: The Final Transition, Operational Maneuver, and Disestablishment of United States Forces-Iraq, Santa Monica, Calif.: RAND Corporation, RR-232-USFI, 2013. As of December 13, 2016: http://www.rand.org/pubs/research_reports/RR232.html

Brigham, Robert K., ARVN: Life and Death in the South Vietnamese Army, Wichita, Kan.: University of Nebraska Press, 2006.

Chubin, Shahram, and Charles Tripp, Iran and Iraq at War, London: I. B. Tauris and Co., 1988.

Chulov, Martin, Fazel Hawramy, and Spencer Ackerman, "Iraq Army Capitulates to Isis Militants in Four Cities," Guardian, June 11, 2014. As of March 6, 2015: http://www.theguardian.com/world/2014/jun/11/ mosul-isis-gunmen-middle-east-states

Central Intelligence Agency, “The World Factbook: Ghana,” cia.gov, January 12, 2017a. As of April 25, 2017:

https://www.cia.gov/library/publications/the-world-factbook/geos/gh.html —, “The World Factbook: Mali," cia.gov, January 12, 2017b. As of April 25, 2017:

https://www.cia.gov/library/publications/the-world-factbook/geos/ml.html

“Chapter Nine: Sub-Saharan Africa," Military Balance, Vol. 115, No. 1, 2016, p. 450.

CIA—See Central Intelligence Agency.

Claudot-Hawad, Hélène, "Iwellemeden Kel Ataram (Touaregs)," Encyclopédie Berbère, Aix-en-Provence: Edisud, No. 25, 2003.

Clausewitz, Carl Philipp Gottlieb von, Vom Krieg, Kindle ed.: Null Papier Verlag, 2012-2015.

Cline, Lawrence, "Lessons from the U.S. Advisory Efforts in El Salvador," Security Assistance: U.S. and International Historical Perspectives, The Proceedings of the Combat Studies Institute 2006 Military History Symposium, Fort Leavenworth, Kans., 2006. 
Colley, Linda, Britons: Forging the Nation 1707-1837, New Haven, Conn.: Yale University Press, 1992.

Cooper, Helene, and Michael D. Shear, "Obama to Send 1,500 More Troops to Assist Iraq," New York Times, November 7, 2014. As of January 31, 2017: https:/www.nytimes.com/2014/11/08/world/middleeast/us-to-send-1500-moretroops-to-iraq.html

Cordesman, Anthony, Iraqi Security Forces: A Strategy for Success, Westport, Conn.: Praeger Security International, 2005.

Cordesman, Anthony H., and Adam Mausner, Withdrawal from Iraq: Assessing the Readiness of Iraqi Security Forces, Vol. 31, Washington, D.C.: Center for Strategic and International Studies, August 2009. As of January 31, 2017: http://csis-prod.s3.amazonaws.com/s3fs-public/legacy_files/files/ publication/090812_Cordesman_WithdrawalIraq_Web.pdf

Crépin, Annie, Vers l'armée nationale: Les débuts de la conscription en Seine-etMarne, Rennes, France: PU Rennes, 2011.

Cumings, Bruce, The Origins of the Korean War, 2 vols, Vol. 2, Princeton, N.J.: Princeton University Press, 1990. , Korea's Place in the Sun, New York: W. W. Norton, 2005.

—, The Korean War: A History, Kindle ed., New York: Modern Library, 2010.

Daddis, Gregory A., No Sure Victory: Measuring U.S. Army Effectiveness and Progress in the Vietnam War, Oxford: Oxford University Press, 2011.

Oxford University Press, 2014.

Defense Security Cooperation Agency, Historical Facts Book, Washington, D.C., 2014.

De Gaulle, Charles, La France et son armée, Vol. 10, Euvres Complètes, Geneva: Edito-Service S.A., 1972.

Devilliers, Philippe, "The Struggle for the Unification of Vietnam," China Quarterly, No. 9, 1962, pp. 2-23.

Devlin, John F., “The Baath Party: Rise and Metamorphosis," American Historical Review, December 1991, pp. 1396-1407.

Dietz, Henry A., Jerrold Elkin, and Maurice Roumani, eds. Ethnicity, Integration, and the Military, Boulder, Colo.: Westview Press, 1991.

Diop, Biram, "Civil-Military Relations in Senegal," in Dennis Blair, ed., Military Engagement: Influencing Armed Forces Worldwide to Support Democratic Transitions, Washington, D.C.: Brookings Institution Press, 2013, pp. 236-256.

DoD_See U.S. Department of Defense. 
Doyle, William, The Oxford History of the French Revolution, Oxford: Oxford University Press, 1989.

Dubrick, James M., Building Security Forces and Ministerial Capacity: Iraq as a Primer, Report I, Best Practices in Counterinsurgency, Washington, D.C.: Institute for the Study of War, August 2009.

Duraid, Adnan, and Tim Arango, "Arrest of a Sunni Minister's Bodyguards Prompts Protests in Iraq," New York Times, December 21, 2012. As of January 31, 2017:

http://www.nytimes.com/2012/12/22/world/middleeast/arrest-of-al-essawisbodyguards-prompts-protests-in-iraq.html

Elliot, Matthew, 'Independent Iraq': The Monarchy and British Influence, 19411958, London: Tauris Academic Studies, 1996.

Eppel, Michael, "The Elite, the Effendiyya, and the Growth of Nationalism and Pan-Arabism in Hashemite Iraq, 1921-1958," International Journal of Middle East Studies, Vol. 30, No. 2, May 1998, pp. 227-250.

Euskirchen, Markus, Militärrituale. Die Ästhetik der Staatsgewalt: Kritik und Analyse eines Herrschaftsinstruments in seinem historisch-systematischen Kontext, Berlin: Freie Universität Berlin, 2004.

Fallows, James, "Why Iraq Has No Army," The Atlantic, December, 2005. As of January 31, 2017:

http://www.theatlantic.com/magazine/archive/2005/12/

why-iraq-has-no-army/304428/

Falola, Toyin, and Matthew M. Heaton, A History of Nigeria, Cambridge:

Cambridge University Press, 2008.

Farouk-Sluglett, Marion, and Peter Sluglett, Iraq Since 1958: From Revolution to Dictatorship, London: I. B. Tauris and Co Ltd, 2001.

"Feierliches Gelöbnis der Bundeswehr 2014 (German TV Broadcast)," YouTube video posted by user Winnie9212, February 14, 2014. As of January 31, 2017: https://www.youtube.com/watch?v=JxFL-BpSk14

Felicetti, Gary, “The Limits of Training in Iraqi Force Development," Parameters, Vol. 36, No. 4, Winter 2006-2007.

Field Manual 3-24, Counterinsurgency, Washington, D.C.: U.S. Department of the Army, 2006. As of January 31, 2017: http://usacac.army.mil/cac2/Repository/Materials/COIN-FM3-24.pdf

Field Manual 3-07, Stability, Washington, D.C.: U.S. Department of the Army, June 2014. As of February 2, 2017:

http://www.apd.army.mil/Search/ePubsSearch/ePubsSearchDownloadPage.

aspx?docID $=0902 \mathrm{c} 85180012226$ 
Fisher-Thompson, Jim, "U.S.-African Partnership Helps Counter Terrorists in Sahel Region,” USEmbassy.gov, March 23, 2004. As of January 31, 2017: http://iipdigital.usembassy.gov/st/english/article/2004/03/20040323170343rlejreh sif0.1366693.html\#axzz4XNXn44MA

Ford, Caroline, Creating the Nation in Provincial France: Religion and Political Identity in Brittany, Princeton, N. J.: Princeton University Press, 1993.

Forrest, Alan, The Legacy of the French Revolutionary Wars: The Nation-in-Arms in French Republican Memory, Kindle ed., Cambridge: Cambridge University Press, 2009.

Francke, Rend Al-Rahim, Political Progress in Iraq During the Surge, Washington, D.C.: U.S. Institute of Peace, Special Report 196, December 2007.

Friedman, Herbert A., "Operation Iraqi Freedom," Psywarrior.com. As of January 31, 2017:

http://www.psywarrior.com/OpnIraqiFreedomcont3.html

Galbraith, Peter W., “The Mess,” New York Review of Books, March 9, 2006.

Galula, David, Counter-Insurgency Warfare: Theory and Practice, New York:

Frederick A. Praeger, 1964.

GAO_-See U.S. Government Accountability Office.

Gaub, Florence, Military Integration After Civil Wars: Multiethnic Armies, Identity and Post-Conflict Reconstruction, Abingdon, Oxon: Routledge, 2010.

-, Rebuilding Armed Forces: Learning from Iraq and Lebanon, Carlisle, Pa.:

U.S. Army War College, Strategic Studies Institute, 2011.

Gentile, Gian, Wrong Turn: America's Deadly Embrace of Counterinsurgency, New York and London: The New Press, 2013.

Gibby, Bryan Robert, Fighting in a Korean War: The American Advisory Missions from 1946-1953, Columbus: Ohio State University, 2004.

Giuffrida, Alessandra, "Métamorphoses des Relations de Dépendance chez les Kel Antessar du Cercle de Goundam," Cahiers d'études africaines, Vol. 3, No. 179-180, 2005, pp. 805-830.

Goodman, Allan E., An Institutional Profile of the South Vietnamese Officer Corps, Santa Monica, Calif.: RAND Corporation, RM-6189-ARPA, 1970.

Gordon, Michael R., "Fateful Choice on Iraq Army Bypassed Debate," New York Times, March 17, 2008. As of January 31, 2017:

http://www.nytimes.com/2008/03/17/world/middleeast/17bremer.html

Gordon, Michael R., and Bernard E. Trainor, Cobra II: The Inside Story of the Invasion and Occupation of Iraq, New York: Vintage, 2006.

Grémont, Charles, Les Touaregs Iwellemedan (1647-1896): Un ensemble politique de la Boucle du Niger, Paris: Karthala, 2010a. 
Tuaregs et Arabes dans les forces armées coloniales et maliennes: Une histoire en trompe-l'ail, Paris: Ifri, 2010b.

Haddad, Fanar, "Why Arab Iraq Survives," Foreign Policy, November 7, 2013.

Handley, Antoinette, and Greg Mills, From Military Coups to Multiparty Elections: The Ghanaian Military-Civil Transition, Working Paper Series, The Hague: Netherlands Institute of International Relations 'Clingendael', November 2001.

Hansen, Emmanuel, and Paul Collins, "The Army, the State, and the 'Rawlings Revolution' in Ghana," African Affairs, Vol. 79, No. 314, 1980, pp. 3-23. As of January 31, 2017:

http://afraf.oxfordjournals.org/content/79/314/3

Hashem, Ali, "How Haider al-Abadi Became Iraq's Next Prime Minister," Al-Monitor, August 24, 2014. As of January 31, 2017:

http://www.al-monitor.com/pulse/originals/2014/08/iraq-iran-prime-ministeralabadi-maliki.html

The Hawk, Iraq Justice and Peace (Al-Saqur, 'Iraq al-'Adala wa al-Salam), Vol. 1, 2005; and Team Six, Two Rivers for Developed Publications (Al-Firqa al-Sadisa, Al-Rafidayn Lil-Matbu'at al-Matura), Vol. 2, 2005.

Henderson, William Darryl, Why the Vietcong Fought: A Study of Motivation and Control in a Modern Army in Combat, Westport, Conn.: Greenwood Press, 1979.

_- "The Vietnamese Army," in Morris Janowitz and Stephen D. Wesbrook, eds., The Political Education of Soldiers, Beverly Hills, Calif.: Sage Publications, 1983, pp. 129-174.

\section{- Cohesion: The Human Element in Combat, Washington, D.C.: National} Defense University Press, 1985.

Hettne, Björn, "Soldiers and Politics: The Case of Ghana," Journal of Peace Research, Vol. 17, No. 2, June 1980, pp. 173-193.

"Histoire de L'armée Française 1789-1870," YouTube video by user Nano GFL, November 25, 2012. As of October 27, 2014: http://www.youtube.com/watch?v=Y7G7xK2Ma38

Hunt, Lynn, Politics, Culture, and Class in the French Revolution, 20th anniversary edition, Berkeley: University of California Press, 1984.

Hutchful, Eboe, "Military Policy and Reform in Ghana," Journal of Modern African Studies, Vol. 35, No. 35, Issue 2, June 1997, pp. 251-278.

Insaidoo, Kwame, Ghana: An Incomplete Independence or a Dysfunctional Democracy? Bloomington, Ind.: AuthorHouse, 2012.

International Crisis Group, Make or Break: Iraq's Sunnis and the State, Brussels, No. 144, August 14, 2013. As of January 31, 2017: https://www.crisisgroup.org/middle-east-north-africa/gulf-and-arabian-peninsula/ iraq/make-or-break-iraq-s-sunnis-and-state 
Iraq's Jihadi Jack-in-the-Box, Beirut and Brussels, June 20, 2014. As of January 31, 2017:

http://www.crisisgroup.org/-/media/Files/Middle East North Africa/Iraq Syria Lebanon/Iraq/b038-iraq-s-jihadi-jack-in-the-box

- Defeating the Iraqi State, One Victory at a Time, International Crisis Group, March 26, 2015. Available at:

https:/www.crisisgroup.org/middle-east-north-africa/gulf-and-arabian-peninsula/ iraq/defeating-iraqi-state-one-victory-time

Ismael, Tareq Y., and Jacqueline S. Ismael, Iraq in the Twenty-first Century: Regime Change and the Making of a Filed State, London: Routledge, 2015.

Jenkins, Brian Michael, Why the North Vietnamese Keep Fighting, Santa Monica, Calif.: RAND Corporation, D-20153-ARPA/AGILE, 1970a. As of December 12, 2016:

http://www.rand.org/pubs/documents/D20153.html

- The Politics of a People's Army, Santa Monica, Calif.: RAND Corporation, D-20531-ARPA, 1970b.

—, A People's Army for South Vietnam: A Vietnamese Solution, Santa Monica, Calif.: RAND Corporation, R-897-ARPA, 1971. As of January 31, 2017:

http://www.rand.org/pubs/reports/R0897.html

Joint Doctrine Note 1-13, Security Force Assistance, Washington, D.C.: U.S.

Department of Defense, 2013.

Kellen, Konrad, A Profile of the PAVN Soldier in South Vietnam, Santa Monica,

Calif.: RAND Corporation, RM-5013-1-ISA/ARPA, June 1966. As of January 31, 2017:

http://www.rand.org/pubs/research_memoranda/RM5013-1.html

Kem, Jack D., and Aaron G. Kirby, "To Change an Army: The Establishment of the Iraqi Center for Military Values, Principles and Leadership," Small Wars Journal, 2009.

Kennedy Boudali, Liane, The North Africa Project: The Trans-Sahara Counterterrorism Partnership, West Point, N.Y.: U.S. Military Academy, Combatting Terrorism Center, 2007. As of December 15, 2016: http://www.dtic.mil/dtic/tr/fulltext/u2/a466542.pdf

Ladisch, Virginie, Possibilities and Challenges for Transitional Justice in Mali, New York, N.Y.: International Center for Transitional Justice, September 2014.

Larsen, Stanley Robert, and James Lawton Collins Jr., Allied Participation in Vietnam, Washington D.C.: Department of the Army, 1975. As of July 29, 2015: http://www.history.army.mil/books/Vietnam/allied/files/6791/allied.html

Lecocq, Baz, Disputed Desert: Decolonization, Competing Nationalism, and Tuareg Rebellions in Northern Mali, Leiden, the Netherlands: Brill, 2010. 
Lecocq, Jean Sebastien, That Desert Is Our Country: Tuareg Rebellions and Competing Nationalisms in Comtemporary Mali (1946-1996), Amsterdam: Academisch Proefschrift, Universiteit von Amsterdam, 2002.

"Letter from LTG John O’Daniel to President Diem," September 29, 1955, Carlisle, Pa.: Army Historical and Education Center, LTG O’Daniel Oral History Reports.

Lewis, Jessica, Ahmed Ali, and Kimberly Kagan, Iraq's Sectarian Crisis Reignites as Shi'a Militias Execute Civilians and Remobilize, Washington, D.C.: Institute for the Study of War, May 31, 2013. As of Decmeber 15, 2016: http://www.understandingwar.org/sites/default/files/IraqsSectarianCrisis_0.pdf

Lomsky-Feder, Edna, and Eyal Ben-Ari, "Performing the People's Army: The Israeli Military Manages Symbolic and Moral Boundaries," in Fran Markowitz, Stephen Sharot, and Moshe Shokeid, eds., Toward an Anthropology of Nation Building and Unbuilding in Israel, Omaha: University of Nebraska Press, 2015.

Long, Austin, “The Anbar Awakening," Survival, Vol. 50, No. 2, April 2008, pp. 67-94.

Maiga, Ahmadou, "Pourquoi le Gatia?," Le Guido, January 2015, p. 20.

"Mali Crisis: U.S. Admits Mistakes in Training Local Troops," BBC News, January 25, 2013. As of May 26, 2015:

http://www.bbc.com/news/world-africa-21195371

"Mali: Lawlessness, Abuses Imperil Population," Human Rights Watch, April 14, 2015. As of December 15, 2016:

https://www.hrw.org/news/2015/04/14/mali-lawlessness-abuses-imperil-population

Al-Marashi, Ibrahim, and Sammy Salama, Iraq's Armed Forces: An Analytical History, London and New York: Routledge, 2008.

Marek, Edward, "ROK Army and Marines Prove to Be Rock-Solid Fighters and Allies in Vietnam War," talkingproud.us, undated. As of July 29, 2015: http://www.talkingproud.us/Military/ROKVIetnam/ROKVIetnamIntro.html

Mariko, Amidou, Mémoires d'un crocodile: Du sujet français au citoyen malien, Bamako, Mali: Éditions Donniya, 2001.

Marshall Jr., Tyrone C., "AFRICOM Commander Addresses Concerns, Potential Solutions in Mali," American Forces Press Service, January 24, 2013. As of December 15, 2016:

http://archive.defense.gov/news/newsarticle.aspx?id=119103

Matthews, Jessica T., “The Surge Has Failed in Its Objective," Carnegie Endowment for International Peace Policy Outlook, September, 2007. As of December 15, 2016:

http://carnegieendowment.org/files/po38_iraq_surge_final.pdf 
Miles, Donna, "New Counterterrorism Initiative to Focus on Saharan Africa," American Forces Information Service, January 15, 2007. As of July 1, 2015: http://web.archive.org/web/20070115212856/http://www.defenselink.mil/news/ May2005/20050516_1126.html

Ministère de la Défense et des Anciens Combatants, "Code de Conduite des Forces Armées et de Sécurité du Mali," Bamako, Mali: Ministère de la Défense et des Anciens Combatants, January 10, 1997.

Ministry of Defence, Republic of Ghana, “Defence,” May 2012, As of May 15, 2015:

http://www.mofep.gov.gh/sites/default/files/pbb/Defence.pdf

Mohammed, Abeer, and Solomon Moore, "Iraq Parliament Purges Hussein Vestiges on Flag," New York Times, January 23, 2008. As of January 31, 2017: http://www.nytimes.com/2008/01/23/world/middleeast/23iraq.html

Morris, Loveday, and Karen DeYoung, "Maliki Steps Aside, Easing Iraq’s Political Crisis," Washington Post, August 14, 2014. As of January 31, 2017:

https:/www.washingtonpost.com/world/middle_east/maliki-agrees-to-step-asideeasing-iraqs-political-crisis/2014/08/14/4535fd40-23ed-11e4-86ca-6f03cbd15cla_ story.html

Nguyen, Lien-Hang T., Hanoi's War: An International History for the War for Peace in Vietnam, Kindle ed., Chapel Hill: University of North Carolina, 2012.

"Nigerian Army Denies Lopsidedness in Promotions, Postings, Retirements," Premium Times, January 11, 2013. As of December 15, 2016:

http://www.premiumtimesng.com/news/119796-nigerian-army-denieslopsidedness-in-promotions-postings-retirements.html

Ozouf, Mona, Festivals and the French Revolution, Cambridge, Mass.: Harvard University Press, 1988.

Paik, Sun Yup, From Pusan to Panmunjon, Washington, D.C.: Potomac Books, 2007.

Parasiliti, Andrew, and Sinan Antoon, "Friends in Need, Foes to Heed: The Iraqi Military in Politics," Middle East Policy, Vol. 7, No. 4, October 1, 2000, pp. $130-140$.

Park, Sang-Seek, "The Military in Ghana," African Studies Review, Vol. 17, No. 1, 1974, pp. 268-271.

Partlow, Joshua, "Maliki’s Office Is Seen Behind Purge in Forces," Washington Post, April 30, 2007. As of January 31, 2017:

http://www.washingtonpost.com/wp-dyn/content/article/2007/04/29/ AR2007042901728.html

Pfiffner, James P., "U.S. Blunders in Iraq: De-Baathification and Disbanding the Army," Intelligence and National Security, Vol. 25, No. 1, 2010, pp. 76-85. 
Phillips, Rufus, Why Vietnam Matters: An Eyewitness Account of Lessons Not Learned, Annapolis, Md.: Naval Institute Press, 2008.

Pincus, Walter, "Mali Insurgency Followed 10 Years of U.S. Counterterrorism Programs," Washington Post, January 16, 2013. As of July 1, 2015: https://www.washingtonpost.com/world/national-security/mali-insurgencyfollowed-10-years-of-us-counterterrorism-programs/2013/01/16/a43f2d32-601e11e2-a389-ee565c81c565_story.html

Pollack, Kenneth M., "Iraq Military Situation Report," Up Front blog (brookings. edu), June 14, 2014. As of March 6, 2015:

http://www.brookings.edu/blogs/up-front/ posts/2014/06/14-iraq-military-situation-pollack

Powelson, Simon, Enduring Engagement Yes, Episodic Engagement, No: Lessons for SOF from Mali, thesis, Monterey, Calif.: Naval Postgraduate School, 2013.

Pribbenow, Merle, "Vietnam's Forgotten Army: Heroism and Betrayal in the ARVN," review, Journal of Military History, Vol. 72, No. 4, October 2008. As of December 15, 2016:

http://muse.jhu.edu/journals/journal_of_military_history/v072/72.4.pribbenow. html

Pribbenow, Merle L., “North Vietnam's Final Offensive: Strategic Endgame Nonpareil," Parameters, Vol. 29, No. 4, Winter 1999-2000, pp. 58-71.

al-Qarawee, Harith, "The Rise of Sunni Identity in Iraq," The National Interest, April 5, 2013. As of January 30, 2017:

http://nationalinterest.org/commentary/sunni-identitys-rise-iraq-8314

al-Qarawee, Harith Hasan, Iraq's Sectarian Crisis: A Legacy of Exclusion, Washington, D.C.: Carnegie Middle East Center, 2014. As of January 30, 2017: http://carnegieendowment.org/files/iraq_sectarian_crisis.pdf

Quinlivan, James T., "Coup-Proofing: Its Practice and Consequences in the Middle East," International Security, Vol. 24, No. 2, Fall 1999, pp. 131-165.

Ramsey, III, Robert D., Advising Indigenous Forces: American Advisors in Korea, Vietnam, and El Salvador, Global War on Terrorism Occasional Paper, Fort Leavenworth, Kan.: Combat Studies Institute Press, U.S. Army Combined Arms Center, 2006.

Rand, Dafna, and Stephen Tankel, Security Cooperation and Assistance: Rethinking the Return on Investment, Washington, D.C.: Center for a New American Security, August 5, 2015. As of January 31, 2017:

https://www.cnas.org/publications/reports/ security-cooperation-and-assistance-rethinking-the-return-on-investment 
Randall, Sara, Where Have All the Nomads Gone? Mali Censuses 1987 and 1998, Note de recherche, Montreal, Canada: Observatoire démographique et statistique de l'espace francophone/Université Laval, 2012. As of December 15, 2016: https://www.odsef.fss.ulaval.ca/sites/odsef.fss.ulaval.ca/files/sara.pdf

Rayburn, Joel, Iraq After America: Strongmen, Sectarians, Resistance, Stanford, Calif.: Hoover Institution Press, 2014.

Redfield, John, "Coalition Assists in Training Thousands of Iraqi Soldiers," U.S. Central Command Public Affairs, MacDill Air Force Base, Fla., March 31, 2015. As of December 16, 2016:

http://www.centcom.mil/MEDIA/NEWS-ARTICLES/News-Article-View/ Article/885042/coalition-assists-in-training-thousands-of-iraqi-soldiers/

"Remarks by President Obama and President John Atta Mills of Ghana," The Chronicle, March 12, 2012. As of February 8, 2017:

http://thechronicle.com.gh/ remarks-by-president-obama-and-president-john-atta-mills-of-ghana/

Renan, Ernest, Qu'est-ce qu'une nation? Paris: Presses Pocket, 1992.

Reveron, Derek S., "Weak States and Security Assistance," Prism, Vol. 1, No. 3, 2010, pp. 27-42.

Reveron, Derek S., and Oleg Svet, "Should the U.S. Increase Security Cooperation to Address Terrorism?" Security Assistance Monitor, December 16, 2015. As of December 15, 2016:

http://www.securityassistance.org/blog/

should-us-increase-security-cooperation-address-terrorism

Ricks, Thomas E., The Gamble: General David Petraeus and the American Military Adventure in Iraq, 2006-2008, New York: Penguin Books, 2009.

Rosen, Nir, "What Bremer Got Wrong in Iraq," Washington Post, May 16, 2007. As of January 31, 2017: http://www.washingtonpost.com/wp-dyn/content/article/2007/05/15/ AR2007051501322.html

Rothenberg, Gunther E., The Art of Warfare in the Age of Napoleon, Bloomington, Ind.: Indiana University Press, 1980.

- The Napoleonic Wars, Smithsonian History of Warfare, London: Smithsonian Books, 1999.

Ruffa, Chiara, "What Peacekeepers Think and Do: An Exploratory Study of French, Ghanaian, Italian, and South Korean Armies in the United Nations Interim Force in Lebanon," Armed Forces and Society, Vol. 40, No. 2, 2013, pp. 199-225.

Republic of Ghana, "Constitution of the Republic of Ghana,” 1992. 
Sahlins, Peter, Boundaries: The Making of France and Spain in the Pyrenees, Berkeley: University of California Press, 1989.

Sawyer, Robert K., Military Advisors in Korea: KMAG in Peace and War, Kindle ed., Walter G. Hermes, ed., Army Historical Series, Washington, D.C.: U.S. Army, Center of Military History, 1988.

Schnapper, Dominique, La Communauté des citoyens: Sur l'idée moderne de nation, Paris: Gallimard, 1994.

Scigliano, Robert, South Vietnam: Nation Under Stress, Boston, Mass.: Houghton Mifflin Company, 1964.

Shapiro, Andrew J., “A New Era for U.S. Security Assistance," Washington Quarterly, Vol. 35, No. 4, Fall 2012, pp. 23-35.

Shaw, Geoffrey, The Lost Mandate of Heaven: The American Betrayal of Ngo Dinh Diem, President of Vietnam, San Francisco: Ignatius Press, 2015.

Silverfarb, Daniel, and Majid Khadduri, Britain's Informal Empire in the Middle East: A Case Study of Iraq 1929-1941, Oxford: Oxford University Press, 1986.

Simon, Steven, “The Price of the Surge: How US Strategy Is Hastening Iraq's Demise," Foreign Affairs, Vol. 87, No. 3, May/June 2008, pp. 57-76.

Smyth, Phillip, “All the Ayatollah's Men," Foreign Policy, September 18, 2014. As of December 15, 2016:

http://foreignpolicy.com/2014/09/18/all-the-ayatollahs-men/

Sullivan, Marisa, Maliki's Authoritarian Regime, Washington, D.C.: Institute for the Study of War, April, 2013.

Sweetland, Anders, Rallying Potential Among the North Vietnamese Armed Forces, Santa Monica, Calif.: RAND Corporation, RM-6375-1-ARPA, 1970. As of January 31, 2017:

http://www.rand.org/pubs/research_memoranda/RM6375-1.html

Tan, Michelle, "Inside the Iraq Mission: What Our Troops Are Doing," Army Times, April 2, 2015. As of December 15, 2016:

http://www.armytimes.com/story/military/2015/04/02/

american-troops-iraq-update-paul-funk-1st-id/70835864/

Tarbush, Mohammad A., The Role of the Military in Politics: A Case Study of Iraq to 1941, New York: Routledge, 1982.

Terrill, W. A., Lessons of the Iraqi De-Ba'athification Program for Iraq's Future and the Arab Revolutions, Carlisle Barracks, Pa.: U.S. Army War College, Strategic Studies Institute, 2010.

Thompson, Kofi, “Military’s Special Forces Must Be Deployed to Halt Illegal Logging," Ghanaweb.com, June 15, 2015. As of February 9, 2017: http://www.ghanaweb.com/GhanaHomePage/features/ Military-s-Special-Forces-Must-Be-Deployed-To-Halt-Illegal-Logging-362431 
Touchard, Laurent, "Décryptage: Paris_-Bamako, je t'aime, moi non plus," conops-mil.blogspot.com, June 8, 2013a. As of November 2, 2016:

http://conops-mil.blogspot.com/2013/06/decryptage-paris-bamako-je-taime-moi. html

"Guerre au Mali: retour sur le drame d'Aguelhok," JeuneAfrique.com, October 21, 2013b. As of December 15, 2016: http://www.jeuneafrique.com/167687/politique/ guerre-au-mali-retour-sur-le-drame-d-aguelhok/

"Armée malienne: les affrontements de Kidal, chronique d'une déroute annoncée," JeuneAfrique.com, May 27, 2014a. As of December 16, 2016 : http://www.jeuneafrique.com/Article/ARTJAWEB20140527131237/

"Défense: où en sont les Forces armées maliennes?" Jeuneafrique.com, June 11, 2014b. As of December 16, 2016:

http://www.jeuneafrique.com/Article/ARTJAWEB20140605155654/

"Mali: retour sur la bataille décisive de Konna," Jeuneafrique.com, January 30, 2014c. As of December 16, 2016: http://www.jeuneafrique.com/Article/ARTJAWEB20140130165338/

“Transcript of President Bush's Address to Nation on U.S. Policy in Iraq," New York Times, January 11, 2007. As of February 7, 2017: http://www.nytimes.com/2007/01/11/us/11ptext.html

U.S. Africa Command, "Africa Contingency Operations Training \& Assistance (ACOTA)," africom.mil, undated. As of February 9, 2017:

http://www.africom.mil/what-we-do/security-cooperation/ acota-africa-contingency-operations-training-and-assistance

U.S. Army, Commander's Handbook for Security Force Assistance (SFA) Brigade and Regimental Combat Team Level (BCT/RCT) in Iraq and Afghanistan, Kindle ed., Fort Leavenworth, Kan.: Joint Center for International Security Force Assistance, 2013.

U.C. Berkeley Institute of International Studies, "Conversation with Colonel Harry G. Summers, Jr.," in Harry Kreisler and Thomas G. Barnes, eds., Conversations with History, March 6, 1996. As of January 31, 2017: http://globetrotter.berkeley.edu/conversations/Summers/summers-con0.html

U.S. Congress, House Committee on Armed Services, Oversight and Investigations Subcommittee, Stand $U_{p}$ and Be Counted: The Continuing Challenge of Building the Iraqi Security Forces, Washington, D.C.: U.S. Government Printing Office, 2007.

U.S. Department of Defense, Foreign Military Training: Fiscal Years 2013 and 2014, Joint Report to Congress, Vol. 1, Washington, D.C., March 26, 2014. As of February 9, 2017:

https://www.state.gov/documents/organization/230192.pdf 
Measuring Stability and Security in Iraq: Report to Congress in Accordance with the Department of Defense Supplemental Appropriations Act 2008, Washington, D.C., December 2008. As of January 31, 2017:

http://usacac.army.mil/cac2/AIWFC/COIN/repository/9010_Report_to_ Congress_Dec_08.pdf

Measuring Stability and Security in Iraq: Report to Congress in Accordance with the Department of Defense Supplemental Appropriations Act 2008, Washington, D.C.: United States Department of Defense, December 2009. As of January 31, 2017:

https://www.defense.gov/Portals/1/Documents/pubs/Master_9204_29Jan10_ FINAL_SIGNED.pdf

U.S. Government Accountability Office, Combating Terrorism: Actions Needed to Enhance Implementation of Trans-Sahara Counterterrorism Partnership, Washington, D.C., GAO-08-860, July 2008. As of January 31, 2017: http://www.gao.gov/new.items/d08860.pdf

Combating Terrorism: U.S. Efforts in Northwest Africa Would Be Strengthened by Enhanced Program Management, Washington, D.C., GAO-14-518, 2014. As of January 31, 2017: http://www.gao.gov/products/GAO-14-518

U.S. House of Representatives, "Statement of Dr. Derek S. Reveron Professor, National Security Affairs U.S. Naval War College Newport, RI Before the House Armed Services Committee on Security Cooperation," Washington, D.C.: U.S. Government Printing Office, October 21, 2015. As of January 31, 2017:

http://docs.house.gov/meetings/AS/AS00/20151021/104083/HHRG-114-AS00Wstate-ReveronD-20151021.pdf

Vickers, George R., "U.S. Military Strategy and the Vietnam War," in Jayne S. Werner and Luu Doan Huynh, eds., The Vietnam War, Vietnamese and American Perspectives, Armonk, N.Y.: M. E. Sharpe, 1993, pp. 123-139.

Warner, Lesley Anne, The Trans Sahara Counter Terrorsm Partnership: Building Partner Capacity to Counter Terrorism and Violent Extremism, Alexandria, Va.: CNA, Center for Complex Operations, 2014.

Weber, Max, Wirtschaft und Gesellschaft, Tübingen: J. C. B. Mohr, 1922.

Weinberger, Sharon, “Iraq's Latest Psychological Operation: Comic Books (Updated)," WIRED, February 19, 2008. As of July 29, 2015:

http://www.wired.com/2008/02/the-latest-io-c/

White House, "Fact Sheet: U.S. Security Sector Assistance Policy," Washington, D.C., April 5, 2013. As of February 2, 2017:

https:/obamawhitehouse.archives.gov/the-press-office/2013/04/05/

fact-sheet-us-security-sector-assistance-policy 
Whitehouse, Bruce, "How U.S. Military Assistance Failed in Mali," bridgesfrombamako.com, April 21, 2014. As of December 16, 2016:

http://bridgesfrombamako.com/2014/04/21/how-us-military-assistance-failed/

"Why Iraq's Army Crumbled," The Economist, June 21, 2014.

Wiest, Andrew, Vietnam's Forgotten Army: Heroism and Betrayal in the ARVN, New York: New York University Press, 2007.

Willbanks, James H., A Raid Too Far: Operation Lam Son 719 and Vietnamization in Vietnam, College Station, Tex.: Texas A \& M University Press, 2014.

Wing, Joel, "A Critical Look at Iraqi Nationalism and Sectarianism, an Interview with Author Harith Hasan al-Qarawee," musingsoniraq.blogspot.com, February 14, 2014. As of March 6, 2015:

http://musingsoniraq.blogspot.com/2014/02/a-critical-look-at-iraqi-nationalism. html

Zubaida, Sami, "Contested Nations: Iraq and the Assyrians," Nations and Nationalism, Vol. 6, No. 3, 2000, pp. 363-382. As of January 31, 2017: http://www.aina.org/articles/contestednations.pdf 
This report proposes an alternative approach to Security Force Assistance (SFA) derived from an interpretation of nation-building and legitimacy formation grounded in history; it argues for the importance of ideas, identities, and ideology, and that SFA efforts often err by focusing too exclusively on force structure, capabilities, and readiness, while ignoring the extent to which a force's development complements the larger nation-building project and the formation of appropriate ideas, identities, and ideologies within the force. The report uses six case studies (South Korea, South Vietnam, Iraq, Ghana, Mali, and Nigeria) to explore the relationship between building armies and building nations as well as potential U.S. contributions.

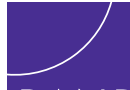

\section{www.rand.org}

